\title{
Design cooperativo: - papel do designer e do usuário na construção de interfaces
}

Marcelo Stein de Lima Sousa

Orientadora

Prof?. Dr Maria das Graças Volpe Nunes 


\section{Design cooperativo: o papel do designer e do usuário na \\ construção de interfaces}

\section{Marcelo Stein de Lima Sousa}

Orientadora

Prof․ Drº Maria das Graças Volpe Nunes

Dissertaçco apresentada ao instituto de Clénclas

Matemáticas de Sõo Carlos da Universidade de São

Paulo como parte dos requlsitos para obtenção do

tifulo de Mestre em Clénclas, na órea de Clếnclas de

Computaçăo e Matemática Computacional.

Instituto de Ciências Matemáticas de São Carlos

Universidade de São Paulo

São Carlos - Novembro de 1993 


\section{Navegar é preciso. Viver não é preciso. \\ Fernando Pessoa}

A Evaldo Montiani Ferreira, que me ensinou a não ter medo de procurar o caminho.

A Azael Rangel Camargo, que me contagiou com a paixấo pelo viajar.

A Maria das Graças Volpe Nunes, que me mostrou a rota segura. 
A meus pais, Rebeca e Milton, meu irmão Flávio;

A Rosana, Cláudia, Tchelo, Marquinhos,

Ricardo, Luis Fernando e Márcio;

Aos professores Maria Carolina Monard

e José Carlos Maldonado;

Aos colegas do Programa de Mestrado;

Aos professores e funcionários do ICMSC;

Meus novos amigos,

Obrigado pela paciência, apoio, incentivo e por

transformarem estes dois anos em uma

experiência que eu adoraria repetir...

Tem um pouco do carinho de vocês em cada página...

Agradeço o apoio que recebi, na forma de bolsa de estudos, da Coordenação de Aperfeiçoamento de Pessoal de Nível Superior, CAPES.

Esta dissertação contou, também, com o apolo do Projeto FAPESP, proc. $n^{\circ}$ 92/2151-8. 
O objetivo desta dissertação é apresentar os principais conceitos, ferramentas e técnicas do $q u e$ se convencionou chamar de design cooperativo. Para tanto, é apresentada a raiz conceitual dos problemas encontrados ao se fazer o design de uma interface com o usuário, discute-se o conceito de perspectiva, e é esboçado um quadro histórico sobre as teorias e métodos de design. Por fim, säo apresentados a filosofia e os conceitos teoricos do design cooperativo, um exemplo de aplicação destes conceitos na construção de interfaces, $e$ algumas das ferramentas e técnicas que estão sendo investigadas.

The goal of this dissertation is to present the main concepts, tools and techniques from what is named cooperative design. For that, we present the conceptual root of the problems found in the user-interface design, discuss the perspective concept, and delineate a historical framework about design theories and methods. Finally, we present the philosophical and theoretical concepts that support cooperative design, an application of this concepts in the interface construction, and some tools and techniques that have being investigated. 


\section{xi Introdução}

1 Capífulo 1 - Uma nova abordagem para o design de interfaces

10 Organizaçठ্s, conheclmento e tecnologia

12 O desenvolvimento de software: uma questáo de design

19 Capífulo 2 - Perspectivas para o design de sistemas e de interfaces

21 Ststemas de informaçáo e contexto

21 Perspectlva determinista

21 Perspectlva mecanicista

23 Perspectiva de sistemas

24 Perspectiva interaclonista

26 Pressuposiçठ̋es sobre o desenvolvimento de Sls

28 Perspectiva funclonailsta

29 Perspectiva relativista social

31 Perspectiva estruturalista social

33 Perspectlva neohumanista

35 O uso de múltiplas perspectivas

36 Conceltos básicos

37 Perspectiva de sistemas

39 Perspectiva de parcelro de díálogo

41 Perspectiva de ferramenta

43 Perspectiva de meio

45 Capítulo 3 - Processos de design: tradiçäo e mudança

48 Deslgn do produto

51 A visão alternativa

53 A Invisibllidade da habllidade e da subjetividade

54 Design para o próximo século

57 O papel da tradlção

59 Colaboraçáo e comunicação

65 Capítulo 4 - Base conceitual para o design cooperativo

68 Substituindo fatores humanos por atores humanos

69 Repensando o concelto de usuário

69 Os usuários não são idjotas

70 Permitir usuários ativos

70 Além das atuals concepçס́es de $\mathrm{HCl}$

71 Do produto para o processo na pesquisa e no design

71 Do Individuo para o grupo

71 Do laboratorlo para o trabalino

72 Do novato para o especlalista

72 Da anáilse para o design

72 Do design centrado no usuárlo para o design com o envolvimento do usuário

73 Da especificaçao formal dos requisitos para a prototipagem iterativa

73 Design situado: ideals adotados

74 Usuários como profisslonals competentes

76 O que estó errado?

77 Ponto de partida 
design cooperativo: o papel do designer e do usuório na construçđo de interfaces

78 O que aprendemos?

79 Novas bases para o design

79 Hermenêutica

80 Compreensð̃o e ontologia

81 Throwness

82 Colapso $\theta$ estar-na-mđio

82 Autopolesis

83 Artefatos

84 Açăo situada

85 Capítulo 5 - A interface com o usuário é onde está a açāo

88 Background térico

89 A attuldade humana $\theta$ a interaçóo homem-computador

90 A atividade de trabalho humana

90 Sumário da teorla da attividade humana

92 Açoes

92 Operaçoes

93 Prática

94 Aspectos comunicativos $\theta$ instrumentals

95 Aprendizagem

96 Aplicaçós computacionais

96 Artefatos computacionais

97 A interface com o usuário

100 Destgn de artefatos computacionals

102 Prática dos designers

103 Design de Interface com o usuário

103 Métodos para design de interfaces

105 Capitulo 6 - Ferramentas e técnicas para o design cooperativo

107 Uma estrutura para a calxa de ferramentas

110 Gerando visóes: workshops futuros $\theta$ design metafórico

111 Background

111 Açoes inicials

111 Fase de Critica

112 Fase de Fantasia

112 Fase de implementaçăo

113 Fazendo réplicas ou colocando as máos no tuturo

113 Por que réplicas?

114 Jogos de linguagem

114 Além do computador de cartão

115 Prototipagem cooperativa

116 Abrodagens para prototipagem

116 Estlmuiando a particlpaçđo $\theta$ a criatividade

117 Exemplo

118 பاढ̧రిes

119 Como uttizar a prototipagem cooperativa

120 Prototipagem via stonboard

121 Construindo blocos

121 Técnica CISP

122 Promessas e probiemas 


\section{Conclusỏes - Cooperaçăo faz sentido}

125 (Auto)crítica do design cooperativo

127 Futuro do design cooperativo

128 Consideraçoes finals

\section{Bibliografia}

\section{Figuras}

4 Figura 1.1. As hablildades necessárias para se lidar com o processo de Informaçóo.

5 Figura 1.2. Os golfos da percepção $\Theta$ da execução.

7 Figura 1.3. Aspectos formals e Informals de um sistema de Informaçóo.

12 Figura 1.4. Partes de um sistema.

13 Figura 1.5. Áreas de formaçáo necessárias para um "arqulteto" da Informaçăo.

24 Figura 2.1. Dimensỏes geradas pelos tipos de pressuposiçóes sobre o conhedimento.

37 Figura 2.2. Relaçóes entre o processo de Interação e suas estruturas.

60 Figura 3.1. As etapas tradiclonals de design do produto.

61 Figura 3.2. Processo de design.

90 Figura 5.1. Attvidade humana.

91 Figura 5.2. Melos $\theta$ atividade humana.

92 Figura 5.3. Attvidades Indlviduals $\theta$ coletiva.

93 Figura 5.4. Attvidade, açóes $\theta$ operaçbes.

98 Figura 5.5. Objeto está presente apenas no artefato.

99 Flgura 5.6. Objeto também exlste fisicamente, mas só está presente como uma representação no apllcattvo.

100 Figura 5.7. Objeto está fisicamente presente fora do artefato.

101 Figura 5.8. Interrelaçnao entre os aspectos de uma Interface.

108 Figura 6.1. Os trés domínlos do discurso no processo de design.

117 Figura 6.2. Representação dileta de dentes em um protótipo de controle adontológlco.

121 Figura 6.3. Blocos construttvos CISP para uma Interface de vídeo. 
design cooperativo: o papel do deslgner e do usuário na construçåo de interfaces

\section{Quadros}

Xil Quadro A. Sumárí das diferenças entre os focos de atençáo dos nívels de desenvolvimento de interfaces como usuário.

10 Quadro 1.1. Comparação entre os modelos organizaclonals tradiclonal $\theta$ emergente.

22 Quadro 2.1. Premissas $\theta$ impllicacóos das perspectivas em termos dos Impactos sobre sistemas de informaçáo.

28 Quadro 2.2. Elementos que compóemo arquétlpo funcionallsta.

30 Quadro 2.3. Elementos que compóem o arquétipo relattivista social.

31 Quadro 2.4. Elementos que compsem o arquétipo estruturalista radlcal.

33 Quadro 2.5. Elementos que compóemo arquétipo nechumanista.

35 Quadro 2.6. Uma taxonomla para perspectivas.

79 Quadro 4.1. Diferenças entre as abordagens tradlclonal e escandinava.

109 Quadro 6.1. Sels áreas de conhedimento para a comunicaçáo usuário/equipe de desenvolvimento.

109 Quadro 6.2. Ferramentas e técnicas para desenvolvimento do conhecimento. 
$\mathrm{Q}$ uando se considera apenas as técnicas de construção de interfaces que são usadas hoje em dia, o número de questões de design não resolvidas é desanimador. A não ser que se duplique um produto já existente, criar o design de umtos aspectos da interface - menu de navegação, operaçס̃es com janelas, nomes para os comandos, atribuição de teclas de função, sintaxe para o mouse, design de ícones, etc. - pode levar a uma série potencialmente sem fim de decisões. Os métodos para se chegar a escolhas bem acabadas são, muitas vezes, demorados e imprecisos. Parece ser necessário um maior número de estudos e pesquisas se a área pretende desenvolver uma base de engenharia com uma utilidade apreciável [77]. Ao mesmo tempo, o design de interfaces com o usuário está passando por um período de grandes modificações. Cores, imagens, sons, vídeo e animações estão começando a ser explorados ou aplicados. Os fundamentos para sistemas mais sofisticados - distriburdos, orientados a objetos, ou baseados em conhecimento - estão apenas começando a encontrar aceitação no mercado. A área de design de interfaces está enfrentando a tarefa de decidir onde investir seus esforços.

O principal foco de atividade no desenvolvimento de computadores se moveu gradativamente do hardware para o software e, agora, está se dirigindo para a interface com o usuário. Um movimento semelhante está presente dentro do domínio de pesquisa e desenvolvimento de interfaces. Esta trajetória pode traçada através dos trabalhos em interação homem-computador: a localização da interface com o usuário se afasta cada vez mais do computador, se dirigindo na direção do usuário e seu ambiente de trabalho. Este redirecionamento, por sua vez, está levando a novas abordagens para o design e a avaliação de interfaces. Pode-se afirmar que estas novas abordagens, respondendo à entrada da interface homem-computador no ambiente de trabalho, vão exigir novas habilidades por parte dos designers, suplementando as utilizadas nas atuais abordagens. No entanto, estas habilidades não podem ser facilmente enxertadas nas atuais práticas de desenvolvimento. Hoje, os metodos aceitos para desenvol ver boas interfaces falham em seus esforços de padronização do processo de desenvolvimento. As abordagens do futuro irão ampliar estes problemas.

É claro que os sistemas sempre tiveramalgum tipo de interface com o usuário: mas como elas evoluíram antes de atrair a atenção dos pesquisadores e designers? Novamente, pode-se encontrar uma série de mudanças nos objeti vos das pesquisas e do design (veja Quadro A). Inicialmente, a interface com o usuário estava localizada no próprio hardware - muitos dos usuários eram engenheiros trabalhando diretamente com o hardware. A atenção, posteriormente, foi desviada para a tarefa de programação - paulatinamente os ambientes e as linguagens de alto nivel libertaram os usuários da necessidade de se familiarizar com o hardware. Em seguida, com o surgimento de sistemas interativos e usuários finais que não eram programadores, a interface passou para o monitor e para o teclado, moti vando as primeiras pesquisas sobre questões motoras e de percepção. Nos últimos anos, pode-se ver uma crescente preocupação com os diálogos coloquiais entre usuários, sistemas e aplicativos, envolvendo questões cognitivas que estão por trás do aprendizado e uso dos sistemas: a interface se prolongou dos olhos e dedos até o cérebro. Por fim, com o advento de idéias como groupware (ou trabalho cooperativo apoiado por computador, veja [52] e [78]) e de sistemas de suporte para organizações, os pesquisadores estão começando a ver o foco de atenção do design de interfaces sendo ampliado para os ambientes social e de trabalho, o que deixa a área 
design cooperativo: o papel do designer e do usuório na construçåo de interfaces

\begin{tabular}{|c|c|c|c|c|c|}
\hline & nivel I & nivel 2 & nivel 3 & nivel 4 & nivel 5 \\
\hline usuárlo principal & $\begin{array}{l}\text { engenhelros, } \\
\text { programadores }\end{array}$ & programadores & "usuório final" & "usuórios finais" & $\begin{array}{l}\text { grupos de } \\
\text { usuários }\end{array}$ \\
\hline $\begin{array}{l}\text { disclplinas do } \\
\text { especiallsta em } \\
\text { intertace }\end{array}$ & $\begin{array}{l}\text { engenharía } \\
\text { elétrica }\end{array}$ & $\begin{array}{l}\text { cléncla da } \\
\text { computaçdo }\end{array}$ & $\begin{array}{c}\text { ergonomia. } \\
\text { psicologia } \\
\text { cognitiva, } \\
\text { design gráfico }\end{array}$ & $\begin{array}{l}\text { psicologla } \\
\text { cognitiva. } \\
\text { cléncla } \\
\text { cogniltiva. (artes } \\
\text { dramáticas?) }\end{array}$ & $\begin{array}{l}\text { psicologia } \\
\text { soclal. } \\
\text { antropologia. } \\
\text { psicologla } \\
\text { organizaclonal }\end{array}$ \\
\hline $\begin{array}{l}\text { mólodos de } \\
\text { pesquilsa }\end{array}$ & $\begin{array}{l}\text { amplamente } \\
\text { informal }\end{array}$ & $\begin{array}{l}\text { amplamente } \\
\text { Informal }\end{array}$ & $\begin{array}{l}\text { experienclas de } \\
\text { laboratório }\end{array}$ & $\begin{array}{l}\text { Wizard of Oz, } \\
\text { pensando em } \\
\text { voz alta. } \\
\text { captura de } \\
\text { dados }\end{array}$ & $\begin{array}{l}\text { etnográfico, } \\
\text { contextual. } \\
\text { observador } \\
\text { participante }\end{array}$ \\
\hline $\begin{array}{l}\text { duroção dos } \\
\text { eventos básicos } \\
\text { estudados }\end{array}$ & $\begin{array}{l}\text { microsegundos/ } \\
\text { horas }\end{array}$ & $\begin{array}{c}\text { millsegundos/ } \\
\text { horas }\end{array}$ & segundos & minutos & dias \\
\hline $\begin{array}{l}\text { custo da } \\
\text { avallação }\end{array}$ & multo balxo & balxo & moderado & alto & multo alto \\
\hline $\begin{array}{l}\text { possibilidade de } \\
\text { generallzar } \\
\text { resultados }\end{array}$ & multo alta & alta & moderada & balxa & multo balxa \\
\hline $\begin{array}{l}\text { período de } \\
\text { atençōo nas } \\
\text { pesquisas }\end{array}$ & 1950 a 1960 & 1960 a 1970 & 1970 a 1990 & $\begin{array}{l}\text { de } 1980 \text { em } \\
\text { diante }\end{array}$ & $\begin{array}{l}\text { de } 1990 \text { em } \\
\text { diante }\end{array}$ \\
\hline
\end{tabular}

\section{Quadro A}

Sumário das diferenças entre os focos de atençóo dos niveis de desenvolvimento de interfaces com o usuário (cf. (77)). de interação homem-computador cada vez mais distante de sua origem dentro do computador [77]. Esta progressão "para fora" é natural. Quando os pesquisadores conseguem resolver os problemas mais urgentes em um nível - ou quando, pelo menos, podem manuseá-los adequadamente -, então os recursos humanos e computacionais já estão disponíveis para se trabalhar no próximo nivel. Neste sentido, o computador está colonizando o seu ambiente - ou, em um tom menos ameaçador, os computadores progressivamente estão aprendendo mais sobre o mundo que os cerca. Este aprendizado geralmente é implícito, refletindo principalmente no aprimoramento do design de sistemas e aplicativos. O Quadro A apresenta um sumário das diferenças entre os focos de atenção para cada um dos níveis de desenvolvimento de interfaces com o usuário.

Esta trajetória de desenvolvimento tem al guma semelhança com o crescimento de uma criança. Existiu uma preocupaçăo inicial com as funçôes físicas básicas (hardware), a seguir surgiu o controle consciente (software) sobre os membros (periféricos) que dão suporte as funções básicas. Em seguida, ocorreu uma expansão de suas relações motoras e perceptivas com o mundo exterior, seguido de um desenvolvimento cognitivo, e finalmente a preocupação com os relacionamentos e estruturas sociais.

Os psicólogos utilizam o conceito de estágios de desenvolvimento para refletir a observação de que as crianças adquirem diferentes habilidades em diferentes momentos. Isto parece ser o que está acontecendo com o desenvolvimento de interfaces. As atividades de diferentes estágios se sobrepðem, e mudanças em uma habilidade podem afetar a performance nas outras. $O$ progresso em niveis mais altos pode ser limitado por causa da falta deconhecimento em níveis mais baixos, mas, ao mesmo tempo, o domínio de um nível não é necessário para se estudar um outro. Como exemplo, pode-se dizer que, apesar da consciência social das pessoas ser limitada ou influenciada pela maturidade na habilidade de raciocinar e planejar, 0 aprendizado cultural e social começa muito cedo e influencia o processamento cognitivo em todos os níveis. Mesmo uma parte importantíssima do hardware das pessoas, o cérebro, continua a amadurecer durante $a$ infância (e se modifica durante toda a vida), com consequências para o aprendizado e o raciocínio em todos os niveis [77]. 
O mesmo parece ser verdadeiro para o desenvolvimento de interfaces. É possfvel identificar estágios durante os quais a interface com o usuário no hardware e, depois, no software receberam a maior parte da atenção. De fato, hoje, por causa das influências entre nf́veis, as soluções otimizadas para as questð̌es de design de um nível dependem de informações obtidas em outros núveis.

Existe, no entanto, discordância sobre como alocar os recursos existentes. Onde aplicar esses recursos? No aprimoramento do software para acelerar mudanças? Em estudos cognitivos e de percepção que possam ser traduzidos diretamente para os aspectos de engenharia? Em uma teoria cognitiva que dê fundamentação para os diálogos de alto nível? Ou em pesquisa social e organizacional que coloque os processos tecnológicos e cognitivos em um contexto de trabalho mais amplo? Em particular, existe um questionamento sobre a necessidade de se pesquisar no nível 5, dadas as dificuldades, a falta de familiaridade com técnicas apropriadas de design de sistemas para grupos, e a necessidade de maior esforço concentrado em outros niveis. $O$ mundo do desenvol vimento de software está começando a aceitar os trabalhos em fatores humanos do nível 3, e não parece poder se ajustar facilmente ao custo, duração e incerteza associados com as técnicas do nível $4 \mathrm{e}$, especialmente, do nível 5 . As empresas de desenvolvimento de software e o processo de desenvolvimento como ele é praticado hoje, foram estruturados sem a preocupação com as necessidades especificas do design de interfaces. Esta situação - acrescida dos conflitos entre o desejo de criar rotinas para o desenvolvimento de software e as incertezas do design de interfaces com o usuário - torna particularmente difícil a ampla utilização dos atuais métodos para o desenvolvimento de interfaces [77].

Bannon [9] afirma que passou "(...) a acreditar que as atuais formas de design e de utilização da tecnologia da informação no trabalho têm restringido, em vez de expandir, o potencial humano. (...) Isto me levou a questionar os valores e perspectivas subjacentes a certas abordagens para o design de sistemas (...) - por exemplo, a idéia de sistemas 'a prova de idiotas'. Isto também me levou a questionar a base té́rica de muitos dos trabalhos em ergonomia cognitiva e em psicologia do processamento da informação, já que pareciam não tratar questōes que eu julgava importantes. Este questionamento da área e a busca paralela por referenciais de trabalho alternativos, me tornaram consciente dos aspectos políticos da organização do trabalho e de como os fundamentos sócio-económicos de nossa sociedade afetam a natureza e a organização de todas as atividades, com ou sem tecnologia. Em outras palavras, os problemas não se devem apenas à natureza da tecnologia em si - apesar disto não ser um elemento neutro -, mas também à organização do trabalho em torno da tecnologia, e à base racional política e sócio-económica de nossa sociedade na qual estas máquinas e sistemas industriais são desenvolvidos".

Como foi notado acima, a otimização em outros níveis muitas vezes exige uma olhada no ambiente de trabalho. Além disso, em áreas onde os aplicativos já amadureceram, onde os produtos com funcionalidades similares estão convergindo para aparências (look \& feel, veja [141-142]) semelhantes, as empresas irão buscar novos maneiras de diferenciar seus produtos. Por fim, da mesma forma que as crianças, o domínio de um nível não é necessário para se progredir em outro. De fato, a partir do momento em que uma criança interage com outra pessoa, pode-se esperar que sua capacidade de raciocínio terá se desenvolvido, mas o mais provável é que esta pessoa, a partir deste encontro, ensinou alguma habilidade social básica à criança (veja a este respeito, [224]). 
A expansão das redes de computadores e do uso de computadores em geral significa que, para melhor ou para pior, o computador está atingindo grupos e organizaçôes, lugares onde é alto o potencial para problemas delicados [77]. Qualquer estratégia que aumente a efić́cia do computador é bem vinda. E se vier acompanhada de aumento na qualidade dos aplicativos e na qualidade de vida das pessoas que utilizam estes aplicativos, melhor ainda.

O objetivo desta dissertação é apresentar os principais conceitos, ferramentas e técnicas do que se convencionou chamar de design cooperativo. Para formar um estado $d a$ arte dessa abordagem procurou-se identificar a raiz conceitual dos problemas detectados durante o design da interface com o usuário. $O$ panorama apresentado reflete a preocupação de buscar uma compreensão das necessidades básicas dos usuários para fundamentar o design cooperativo. Nesta busca, foram identificados na literatura alguns dos caminhos que consolidam esta abordagem como uma evolução natural para a metodologia do design de interfaces. É necessário destacar que, uma das principais implicações desta metodologia de design, é a de que estão surgindo novos papéis durante o desenvolvimento de sistemas.

Dentro deste quadro, os capítulos da dissertação apresentam a seguinte distribuição:

O Capítulo 1 procura estabelecer de que maneira as exigências e características do ambiente social e de trabalho do usuário estão afetando o design e o desenvolvimento de sistemas e interfaces. A preocupação básica é a de esboçar um quadro de como o desenvolvimento tecnológico afeta a sociedade de uma maneira geral e, em contrapartida, como a sociedade influencia diretamente os métodos e técnicas escolhidos para o design e desenvolvimento de aplicativos e suas interfaces.

O Capítulo 2 apresenta o conceito de perspectiva, dentro da visão sugerida por três artigos da literatura pesquisada. A utilização desse conceito é pertinente, no sentido de situar os argumentos apresentados no Capítulo 1 dentro da evolução dos fundamentos teóricos para os métodos e técnicas apresentados nos capíbulos seguintes para o design e desenvolvimento de sistemas e interfaces.

o Capítulo 3 esboça um quadro histórico sobre as teorias e métodos de design, enfatizando como as atuais discussð̃es apresentadas na literatura estão influenciando o pensamento sobre o design aplicado a área de informática e, em particular, de interfaces.

O Capítulo 4 introduz, a partir do quadro de referencia apresentado no Capítulo 3 , a base filosofica e alguns dos principais conceitos terricos que fundamentam o conjunto de ferramentas e técnicas do design cooperativo.

o Capítulo 5 apresenta os conceitos e argumentos da teoria da atividade humana - que pode ser compreendida como uma extensão dos princípios teóricos do Capítulo 4 -, que servem como delineamento de uma metodologia para o estudo e a construção de interfaces.

O Capítulo 6 agrupa a descriçao de algumas das principais técnicas e ferramentas que estão sendo utilizadas no design cooperativo, procurando enfatizar a característica básica de constituirem um instrumental em desenvolvimento.

Cooperação faz sentido procura extrair conclusóes sobre o que foi apresentado, ressaltando as questões ainda por resolver, qual o futuro desta abordagem no design de interfaces e de sistemas, e apresenta possfveis caminhos para o estudo e a pesquisa na área. 


\section{Uma nova \\ abordagem para 0 \\ design de interfaces}

Cada capítulo da

dissertaçáo começa com

uma ilustraçáo que se refere

tanto ao poder das formas

de comunicaçao quanto ao

conteúdo do capítulo. A

caligrafia é uma das mais

antigas formas de

comunicação e, aqui, Scott

Kim mostra o que pode ser

feito quando o comunicador compreende e sabe manipular os fatores que afetam a percepcalo da audiência.

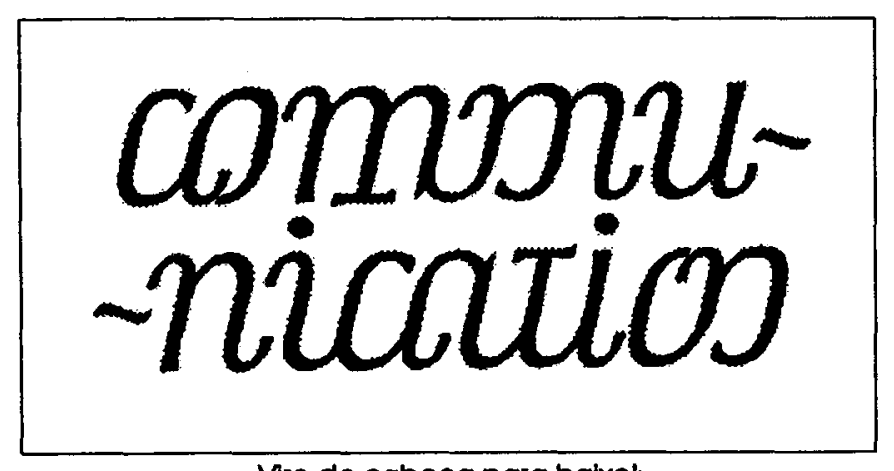

Vire de cabeça para balxo! 


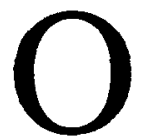

que há de errado com as interfaces? Para começar, a pergunta. Ela dá a entender que já se fez todo o resto do sistema. Esta atitude é o que está errado com a interface, com o design de interface. Na verdade, isto ocorre com todo o tipo de design, seja ele de casas, escritórios, banheiros, máquinas de lavar ou videocassetes. E, é claro, com os maiores "pecadores" de todos, os computadores [185].

$O$ que todo designer de interface precisa ter em mente é que ele é um designer de sistema. As preocupações usuais destes designers de interface - criar familias de letras para a tela, aprimorar os elementos gráficos que podem ser manipulados, integrar cor, som e voz - são todas considerações importantes. Mas são secundárias. Aprimorar a maneira pela qual as pessoas podem usar os computadores para pensar e se comunicar, observar e decidir, calcular e simular, debater e criar - estas são as preocupaçôes primárias.

O design de interfaces humanas (não apenas para computadores) é uma área excitante exatamente porque seu objetivo é o de modificar o mundo através da melhoria da forma pela qual as pessoas realizam tarefas nas escolas, escritórios, fábricas ou residências. Novas idéias, novas tecnologias, novas culturas, novos empregos, novas indústrias, novas visões de mundo serão os eventuais resultados de interfaces bem desenvol vidas para computadores. A principal tarefa do designer $e$, na verdade, a de auxiliar as pessoas a cooperarem umas com as outras. Interfaces com o usuário, tecnologia da computação e todas as ferramentas que as pessoas usam para pensar são parte de um processo evolutivo [219]. Um design que funciona modifica a maneira das pessoas pensarem, o que permite, por sua vez, criar sistemas mais eficientes.

Mas quais são estes sistemas? Como incluir estes sistemas neste processo evolucionário? Qual o papel da interface? Como incluir a interface no desenvolvimento do sistema? Quais são as consequiências geradas por estes sistemas, tanto na sociedade quanto no desenvolvimento e planejamento dos sistemas?

As respostas a estas perguntas dependem justamente de como será definido o tipo de interface a ser projetado. Esta definição, por sua vez, depende das necessidades e exigências do mercado, da sociedade e dos usuários. Foram sugeridas diversas respostas, mas todas parecem ter como origem uma habilidade - por estranho que pareça - muito comum na humanidade: a de se comunicar.

Recentes desenvolvimentos na área de eletrónica - tais como telefone, televisão, computador - fizeram com que algumas atividades que se supunham corretas e jáocorriam de maneira natural na cultura fossem repensadas. Para executar estas atividades, os seres humanos criaram, durante a evolução da humanidade, dispositivos que permitiram transmitir e receber, guardar e recuperar, processar e transformar aquilo a que as pessoas se referem como informação. 0 desenvolvimento de técnicas que permitiram aproveitar o potencial destes dispositivos obrigou a sociedade a um grande, deliberado e imaginativo esforço de pensamento'.

É por causa das similaridades funcionais entre o uso destes dispositivos - escrita, imprensa e telecomunicaçóes - que se pode pensar em uma famf́lia de tecnologias ([147-149]). Olhando para o passado, épossível identificar as tecnologias da informação como sendo altamente consumidoras de tempo, extremamente trabalhosas e inconvenientes, o que permite considerar os novos meios eletrónicos simplesmente como economizadores de trabalho, da mesma forma que um motor pode ser visto como um substituto para o esforço de bombear água com as mãos [24]. No entanto, o mundo
1. Veja (132) $\theta$ (219) para mais detalhes sobre o desenvolvmento destas técnicas $\theta 0 \mathrm{im}-$ pacto na manelra de pensa da humanidade. 


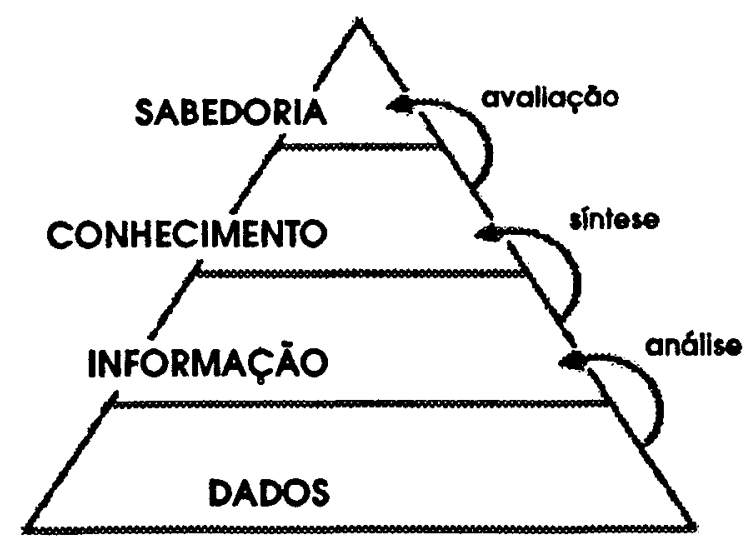

Foura 1.1

As habilldades necessárias para se lldar com o processo de informaçăo (cf. (87)).
2. Por outro lado, quem estlver lendo esta pógina possul uma impressionante qualificaço chamada alfabetizaçōo. A malorla de nossos ancestrals nóo era so de lletrados. mas também de "inumerados" significando quendo sablam fazer omaissimples cálculo aritmetico (221). O que isso ressalta é que multas das mals simples qualificaçoestidas comoponto paclfico na sociedade de hoje sáo produto de séculos de progresso cultural curnulativo. Geraçoes sucessivas de pessoas aprenderam essas habilidades, adaptaram-nas. transmittiram-nas $\theta$ construlram uma socledade sobre os resuttados conseguidos.

Em raros momentos na historla o avanço do conhecimento tem derrubado velhas barrelras. A mais importante destas quedas tem sido Justamente a invençoo de novas ferramentas para o raclocínio e a comunlcacao. como o ideograma, o alfabeto, o zero $\theta$. no nosso século. o computador.

Apesar dlsso, quando a imprensa fol Inventada ja se conhecla a escrita há mais de dols mil anos $\theta$ apenas uma pequena elte sabla ler, $\theta$ menos ainda escrever (90). desenvolvido está experimentando uma transformação convergente das tecnologias da computação e da comunicação cujo impacto deverá rivalizar com o da substituição da força muscular pela máquina [225] $]^{2}$.

Hoje, a humanidade passa por um destes pontos de virada da história em que toda a estrutura do conhecimento humano está tremendo uma vez mais com a mudança, à medida que caem velhas barreiras. A humanidade está reorganizando totalmente a produção e a distribuição do conhecimento e os símbolos usados para comunicar esse conhecimento.

O que isso significa? Significa que as pessoas estão criando novas redes de conhecimento, ligando os conceitos uns com os outros de maneira inovadora, armando notáveis cadeias de inferência, desovando novas teorias, hipóteses e imagens baseadas em inusitados pressupostos, novas linguagens, códigos e lógica. O queé mais importante, estão inter-relacionando dados de múltiplas maneiras, dando-lhes contexto, e assim transformando-os em informações; e estão reunindo pedaços de informações para formar modelos e arquiteturas de conhecimento cada vez maiores ${ }^{3}$.

Significa, por outro lado, que o mundo está passando da Era Industrial para a Era da Informação. É um momento de profundas mudanças, no qual os recursos econômicos básicos não mais serão capital, trabalho e matéria prima, mas conhecimento, inovação e informação [221].

As tecnologias que estão surgindo hoje permitirão que as pessoas explorem, transportem ecriem conhecimento como nunca foi possível antes. Eos sistemas computacionais deverão dar suporte para estas atividades, auxiliando o usuário no ingresso em uma infra-estrutura global cada vez maior e mais potente.

Para que as pessoas possam manipular este conhecimento produzido globalmente nos sistemas - ditos de informação, mas, parece, de conhecimento talvez fosse melhor - é necessário redefinir as metas na área de desenvolvimento de sistemas no sentido de [40]:

(a) aumentar o empenho na construção de sistemas de informação que possam acomodar qualquer tipo de manifestação do conhecimento: texto, vídeo, som, regras, casos, procedimentos, ou habilidades humanas;

(b) expandir os esforços na obtenção de conhecimentos para incluir, além de fontes humanas, qualquer repositório de conhecimento: livros de referência, artigos, material de treinamento, relatórios, legislação, patentes, e assim por diante;

(c) ampliar 0 alcance das ferramentas para um conjunto mais amplo de tecnologias do conhecimento; é preciso incluir todas as formas e fontes de conhecimento: processamento de regras, programação orientada a objeto, raciocínio baseado em casos, hipermídia, redes neurais, groupware, e mesmo as antigas ferramentas para codificação procedimental. 


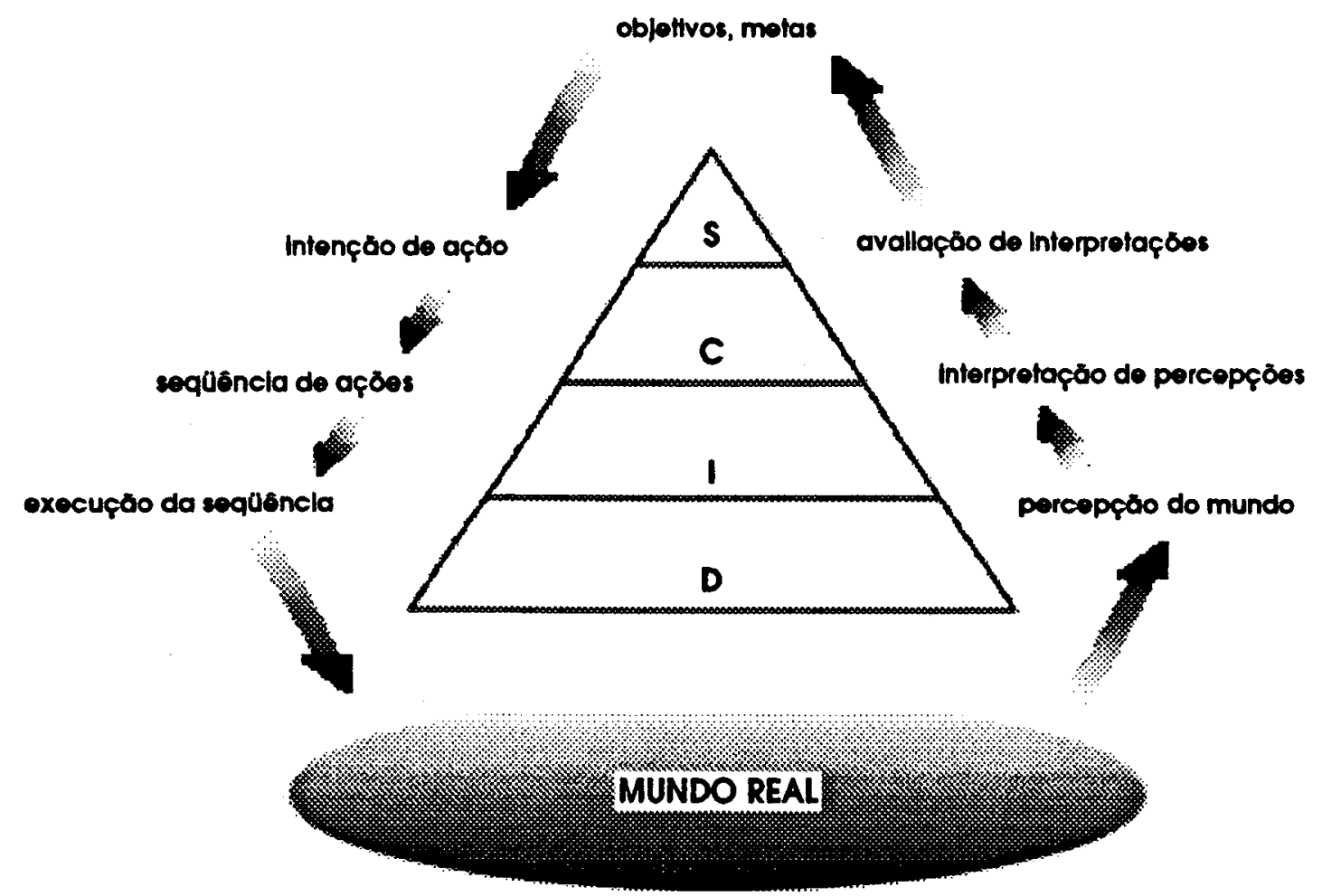

A razão básica para esta mudança de atitude é que o processo de informação está preocupado com três habilidades (veja Figura 1.1): a análise dos dados, que gera informação; a síntese destas informaçães, que gera conhecimento; e a avaliação desse conhecimento [87]. Estas três habilidades serão as preocupações dos designers de sistemas (e, portanto, de interfaces) na Era da Informação.

Entretanto, do ponto de vista do usuário, saber ler, escrever e contar não significa ser funcionalmente letrado em uma sociedade da informação. Para ser produtivo nesta sociedade - o que significa ser funcionalmente letrado —, um indivíduo deverá ser um letrado auditivo, visual e em computadores. Ser letrado significa possuir a habilidade de manipular os meios de comunicação. Como a informação é a base da comunicação, ser letrado e ser letrado em informação são a mesma coisa. A definição de al fabetizado continua a mesma. O meio de comunicaf̧ão mudou.

Ser letrado - ou produtivo - nesta sociedade significa ser competente na manipulação dos elementos que definem o uso de cada meio. Os elementos são compreensão (análise ou decodificação dos dados), tradução e criação (síntese de informaçð̃es) e avaliação. Os meios de comunicação são o impresso, o sonoro, o visual e o computador.

No entanto, apenas ser funcionalmente letrado não e suficiente para se viver na sociedade. As habilidades de análise, síntese e avaliação também devem ser utilizadas quando uma pessoa quer fazer alguma coisa. Para fazer alguma coisa, deve-se começar com uma boa noção do que se quer fazer - o objetivo ou meta que se quer alcançar. Então, deve-se fazer algo ao mundo, isto $e$, agir no sentido de se mover ou manipular algum objeto. Por fim, deve-se verificar se o objetivo foi alcançado. Assim, existem quatro aspectos a considerar: o objetivo, o que é feito ao mundo, o mundo propriamente dito, $\mathrm{e}$ a verificação que se faz. Portanto, uma ação possui dois lados igualmente importantes: fazer al guma coisa e verificar o resultado dessa ação. Norman [173-175] denomina estes dois lados de golfos de execução e de avaliação (Figura 1.2).

Mas as tarefas reais não são tão simples. $O$ objetivo pode - e geralmente é o que

Flgura 1.2

Os golfos da percepção e do execução (ct. (174)).

3. Soro exemplos disso a enorme extenscio da malha de redes de comunicaçăo descrita por (190), a implantaçó do World Wide Web. desenvolvida no CERN, o projeto Gutenberg. quepretende colocarno rede Internet um milhăo de textos até o ano 2000, e 0 grande número de áreas de conhecimento das ilstas de discussao reallzadasnasiedes. deve fazer. Para executaruma ação, os objetivos devem ser transformadosem declaraçôes 
precisas do que deve ser feito, declaraçôes que Norman chama de intençōes[170]. Um objetivo é algo a ser alcançado e, muitas vezes, repetimos, está vagamente definido. Uma intenção é uma ação espećfica para se atingir este objetivo.

Após especificar que ações executar, elas devem ser realizadas - a etapa de execução. Assim, a partir de um objetivo, seguem-as etapas: de intenção, sequiência de ações e execução. $O$ lado da avaliação, verificando o que foi realizado, também possui três etapas: perceber o que acontece no mundo, tentar dar sentido ao que se percebeu (uma interpretação), e comparar o que aconteceu com o que se desejava.

Todas essas etapas podem começar em qualquer ponto do ciclo mundo-avaliaçãoobjetivo-execução-munđo. Não existe, necessariamente, um procedimento completo e lógico. Em um número surpreendente de eventos do dia-a-dia, as pessoas encontram di-

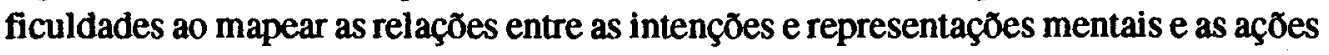
e estados físicos. Existem diversos golfos que separam estados mentais dos estados físicos. Cada golfo reflete um dos aspectos que distanciam as representaçóes mentais de uma pessoa dos componentes físicos e estados do ambiente. Estes golfos representam grandes problemas para o usuário.

Por estas razões, para desenvolver sistemas confiáveis, eficientes e de alta qualidade é necessária a compreensão de teorias e práticas oriundas de disciplinas já bem estruturadas [128], como, por exemplo, a psicologia e a sociologia. Qualquer organização humana precisa de um sistema de informação para funcionar eficientemente. Alguns dos componentes deste sistema são artefatos - lápis e papel, processadores de texto, computadores e redes de comunicação, sistemas operacionais e manuais de procedimento. Mas todo sistema precisa de pessoas para construir, operar e trabalhar com os equipamentos. Na prática, todo sistema depende do uso e da interação de pessoas com equipamentos. Um modelo como o da Figura 1.3 ilustra o relacionamento entre os diferentes componentes de um sistema de informação e seus aspectos formais e informais.

Um sistema de informação existe em um mundo real formado por objetos (alguns concretos, outros abstratos), pessoas, regras, normas e comandos. Uma pessoa (o usuário da Figura 1.3) realiza uma tarefa em relação a este mundo real. Para realizar a tarefa, a pessoa precisa de informações sobre o mundo. Isto muitas vezes pode ser obtido diretamente do mundo real. Ou, o usuário pode utilizar sistemas formais e informais para obter a informação de que precisa.

A maior parte dos sistemas possui estas três principais fontes de informação: o mundo real que, por si mesmo, pode ser pesquisado; o sistema de informação projetado (o equipamento ou um artefato - conceito que será detalhado nos Capítulos 4 e 5) que, supðe-se, deva fornecer uma imagem exata do mundo real; e o sistema informal que, muitas vezes, substitui o sistema projetado e que é muito utilizado para fornecer informações qualitativas sobre o mundo real.

A maneira pela qual uma pessoa se utiliza das informações destas três fontes depende de uma série de fatores. Os mais importantes são [128]:

(a) As preferências e o estilocognitivos da pessoa que recebe as informações. Cada indivíduo irá perceber o conteúdo da mensagem recebida através de um filtro cognitivo que irá selecionar, amplificar, rejeitar, atenuar ou distorcer porções da mensagem. Assim, mesmo as mais simples mensagens serão interpretadas diferentemente por diferentes indivíduos (veja [111]). 
mundo real

objetos: pessacis, iegros:

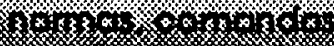
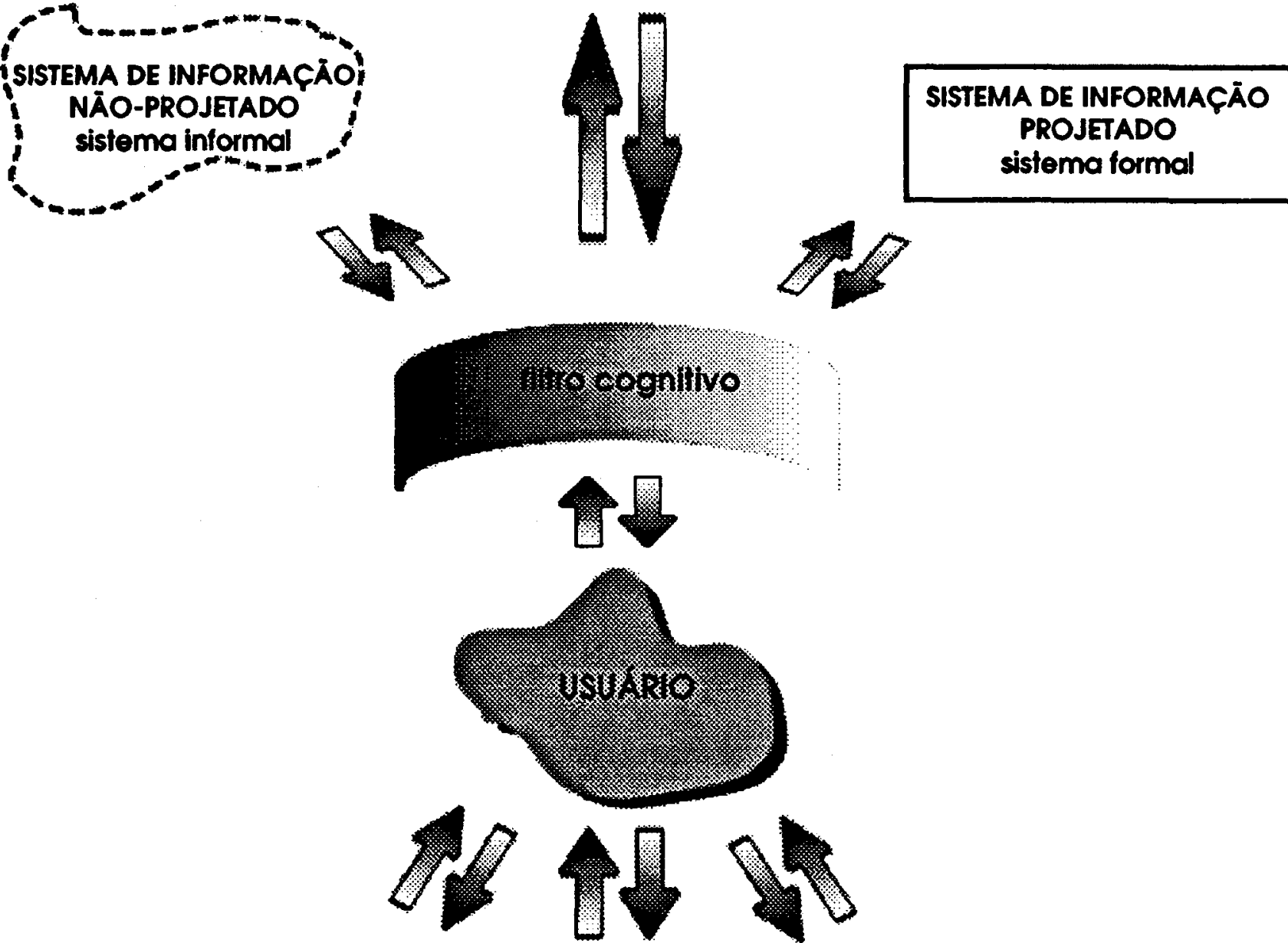

380.101010
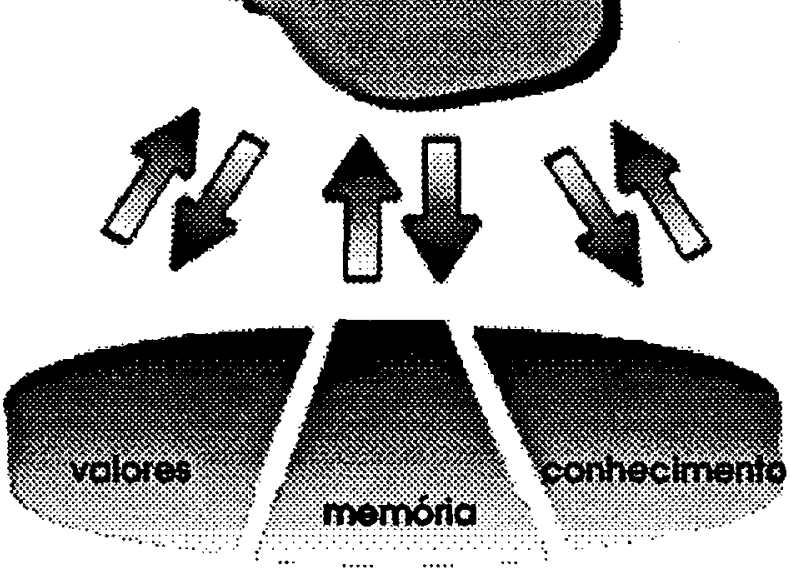

(b) Igualmente importante é o conhecimento que uma pessoa tem na memória. É a associação entre a informação recebida através dos sentidos com o conhecimento que está na memória do indivíduo que irá determinar as ações e/ou respostas à mensagem recebida. Este é um processo que não pode ser

Figura 1.3

Aspectos formals $\theta$ informals de um sistema de Informaçăo (ct. (128)) previsto (veja [174]).

(c) O terceiro fator é a linguagem. Toda informação é transportada a uma pessoa na forma de signos e mensagens. Para que haja significado eles precisam ser incorporados a um código ou linguagem. Linguagens diferentes (música, gestos, etc) possuem propriedades diferentes com relação à interpretação de seus códigos (veja [134]). 
Linguagem, estilo cognitivo e memória operam interdependentemente. As rázes de seu funcionamento estão associadas à cultura, educação e experiência do indivíduo. Além disso, existe um grande número de fatores ambientais e circunstanciais que influenciam a maneira pela qual uma pessoa reage à informação e a qual fonte ela prefere recorrer.

Benedikt sugere que, na área de interação homem-computador, sejam adotadas quatro linhas de pesquisa básica para que se possa entender como a humanidade transformou imagens, sons, estórias, dados - padrões de pura informação - em templos, catedrais, mercados, tribunais, bibliotecas, teatros, cartas, livros, filmes, vídeos, CDs, jornais, performances artísticas, shows... - que, no fundo, são manifestações físicas daquelas estruturas abstratas [10]. As linhas são:

(a) A mais antiga começa na linguagem, talvez antes, com o estabelecimento de uma comunhão de mentes entre os membros de uma tribo ou grupo social. Esta comunhão auxilia na coordenação do grupo em torno de um conjunto de crenças: sobre o ambiente, os perigos naturais, o que é sensato e o que não é, sobre o passado e o futuro, o que está "dentro" das coisas, o que está além do horizonte, embaixo da terra, acima do céu. De certa forma, a mente do grupo nasce antes da mente individual. Estas questões e suas respostas aglutinam-se em sistemas de narrativas, personagens, cenas, leis e liçð̃es mais ou menos coerentes que, hoje, são reconhecidos - muitas vezes de forma depreciativa - como mitos.

(b) Junto com a história do mito está a linha de historia da tecnologia dos meios, isto $\mathrm{e}$, a história das descobertas técnicas através das quais entidades ausentes e/ou abstratas - eventos, experiencias, idéias - podem vir a ser representadas simbolicamente, "fixadas" em algum material, e assim conservadas através do tempo e do espaço. Esta linha se inicia com a cooptação humana de seu ambiente físico, particularmente daquelas partes que melhor recebem "marcas" - como areia, madeira, ossos, cascas, pedras e o corpo humano -, com o propósito de preservar e enviar mensagens.

(c) Outra narrativa que pode ser utilizada é a da historia da arquitetura. A linha pode começar a partir do estudo das respostas criativas as forças climáticas, com a escolha de lugares adequados para a construção de povoados (e para a defesa deles), eo desenvolvimento interno de estruturas sociais para satisfazer às pressões populacionais e de recursos, além dos mecanismos de privacidade, propriedade, legitimaçăo, especialização de tarefas, cerimônias, etc. Tudo isto teve de ser to. $O$ que isso significa? Significacde de tempo, materiais, e habilidades de design e construção.

(d) A última linha é traçada a partir da história da matemática. É uma linha baseada nos argumentos e idéias que giram em torno (1) das proposiçôes sobre geometria e espaço; (2) da possibilidade de dar forma espacial (tridimensional) as operaçбes aritméticas/algébricas; $\mathrm{e}$ (3) da reconsideração da natureza do espaço à luz das mudanças do item anterior. Esta é uma linha que permitiu novos desenvolvimentos em lógica simbólica, notação algébrica, cálculo, matemática finita, etc. Por outro lado, álgebra, teoria dos números, teoria computacional, lógica... são operaçães simbólicas sobre operaçð̃es 
simbólicas e têm vida própria. É uma linha que deu permitiu o surgimento de conceitos como sistema cartesiano, geometria não-euclidiana, teoria da relatividade, mecánica quântica, topologia, fractais e teoria dos grafos.

O que estas linhas indicam é que um sistema de informação ê um sistema sóciocultural, no qual está embutida uma específica tecnologia da informação [116-119]. A parcela de participação desta tecnologia está crescendo rapidamente. Mas isto não significa que o sistema total deixará de ser um sistema socio-cultural, nem que seja possível projetar um sistema de informação robusto e eficiente, incorporando quantidades significativas de tecnologia, sem tratá-lo como tal. Não é suficiente projetar um sistema técnico e, em seguida, tentar torná-lo "amigável", ou apenas avisaro designer que ele deve levar em conta os fatores humanos.

A questão que se coloca, hoje, para os construtores de um sistema é a de como atender a todos estes requisitos de maneira a se ter um sistema regido pelos parâmetros de qualidade e confiabilidade adotados como padrão na construção de sistemas. Kapor destaca que "o problema de se fazer sistemas úteis para as pessoas como dispositivos de comunicação e informação não é um problema de engenharia. É um problema de design. Os engenheiros são treinados para eliminar os fatores subjetivos. Mas são exatamente os fatores subjetivos que são críticos nesta situação" (citado em [225]). Já Heckel [87] acredita que:

"Muitos de nós gostamos de uma fórmula que possamos seguir para obter resultados garantidos. À falta disto, gostamos de um problema bem definido cuja solução podemos otimizar. Isto é particularmente verdadeiro para aqueles de nós que são engenheiros. Esperamos que os parâmetros do problema sejam fornecidos. Não os questionamos. No colégio, aprendemos as leis de Newton e as equaçóes de Maxwell, e descobrimos que um pequeno número de equaçães muito poderosas explica a mecânica e a eletrônica. $\mathrm{Na}$ escola, usamos estas e outras leis similares para resolveruma ampla variedade de problemas. Uma vez que tenhamos encontrado a maneira correta de resolver um tipo de problema, raramente olhamos para eles de outra maneira.

Infelizmente, temos atendência de esperar que outras coisas sejam explicadas por fórmulas ou receitas não-ambíguas - desde que possamos encontrar aquela que é correta. Seguindo esta abordagem, quando nos defrontamos com um problema complexo, fazemos suposiçoes simplificadas para tornar o problema manuseável. Mas, ao fazermos isto, tendemos a esquecer as suposições, deixando o problema real flutuando ao acaso enquanto nos concentramos em resolver o problema simplificado que criamos. Invariavelmente obtemos a solução correta para o problema errado.

Quando lidamos com problemas mais flexíveis, como comunicar com pessoas, não existe uma maneira correta de resolvê-los. Devemos pensar de maneiras diferentes e olhar para o problema a partir de vários ângulos. Cada novo ângulo pode eliminar algumas soluçð̃es experimentais, sugerir uma nova, ou fornecer um novo insight para o problema. Cada ângulo acrescenta alguma coisa à imagem que se está construindo na mente."

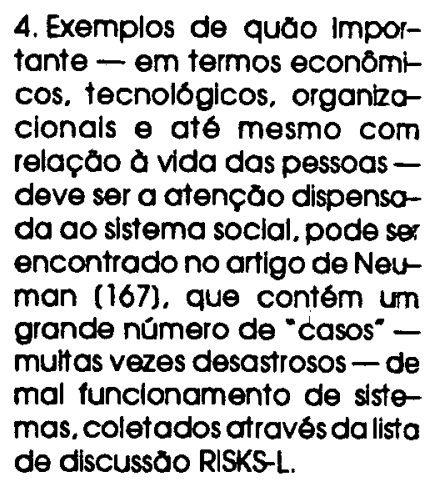

4. Exemplos de quăo importante - em termos económi cos, tecnológicos, organizacionals $\theta$ até mesmo com relaçóo d vida das pessoas deve ser a atençð̃o dispensada ao sistema social. pode ser encontrado no artigo de Nevman (167), que contem um grande número de "casos" multas vezes desastrosos - de mal funcionamento de sistemas, coletados através da lista de discussõo RISKS-L. 
As relaçôes de poder estabelecidas antes, durante e após a instalação de um sistema vão determinar e condicionar seu uso [139]. Isto significa que, para entender estas relações e a intricada rede de interrelaçðes existente - pensando-se em um futuro próximo -, é necessário compreender como a sociedade está se reorganizando.

\section{Organizações, conhecimento e tecnologia}

Na Era da Informação a maior fonte de recursos é o conhecimento. Terra, trabalho e capital - os tradicionais fatores de produção adotados pelos economistas - não desaparecerão, mas se tomarão secundários. Eles poderão ser obtidos desde que exista conhecimento especializado. Ao mesmo tempo, o conhecimento especializado por si só não produz nada. Ele só será produtivo se estiver integrado a uma tarefa. E esta éa razão pela qual a sociedade da informação também é uma sociedade de organizaçóes: o propósito e função de cada organização, seja ela de que tipo for, são os de integrar conhecimentos específicos em uma mesma tarefa [57].

Em particular, as tensões e questões centrais com as quais a sociedade de organizaçōes se defronta já são conhecidas: a tensão criada pela necessidade de estabilidade da comunidade e a necessidade da organização de se desestabilizar; o relacionamento entre indivíduo e organização e as responsabilidades de um para com o outro; a tensão que surge da necessidade de autonomia da organização e o interesse pelo bem comum da sociedade; a crescente demandapor organizaçães socialmente responsáveis; a tensão entre especialistas com conhecimentos específicos e a necessidade de se atuar em grupo.

Sociedade, comunidade e família são todas instituições conservadoras. Mas as organizações modernas são desestabilizadoras por natureza, buscam a mudança, precisam inovar. E inovar é uma "desconstrução criativa": sistematicamente abandonar tudo que esteja bem estabelecido, que seja familiar ou que pareça confortável - seja um conjunto de habilidades, sejam relações sociais e humanas. É preciso estar preparado para mudanças contínuas. A função de uma organização é a de colocar o conhecimento para trabalhar - em ferramentas, produtos ou processos, no design do proprio trabalho, do próprio conhecimento. Na verdade, as organizações deverão cada vez mais planejar 0 abandono, ao invés de tentar prolongar a vida de um produto, política ou prática de sucesso.

Cada organização deverá se dedicar a criar o novo, o que implica em adotar três práticas sistemáticas. A primeira éo aprimoramento contínuo de tudo o que a organização faz. A segunda é a de aprender a explorar seu conhecimento, isto é, desenvolver a próxima geração de aplicações a partir de seus próprios sucessos. E, por último, aprender a inovar - e inovação pode ser e precisa ser organizada - como um processo sistemático.

Como a organização moderna consiste de especialistas em conhecimento, ela precisa ser uma organização de iguais, de colegas e associados. Nenhum conhecimento é maior ou melhor do que outro, cada um será julgado por sua contribuição à tarefa comum ao invés de por uma superioridade ou inferioridade inerente. Assim, a organização moderna não pode ter chefes ou subordinados. Ela precisa ser estruturada em termos de uma equipe, de um grupo. Precisam ser organizaçôes baseadas em responsabilidade, onde cada membro precisa agir como responsável pelas decisð̃es tomadas.

Muitas organizaçð̃es estão em meio a mudanças fundamentais em suas estruturas epráticas administrativas [6]. Tanto as organizaçoes pioneiras quanto as tradicionais estão experimentando novas estruturasorganizacionais e novos processos administrativos 


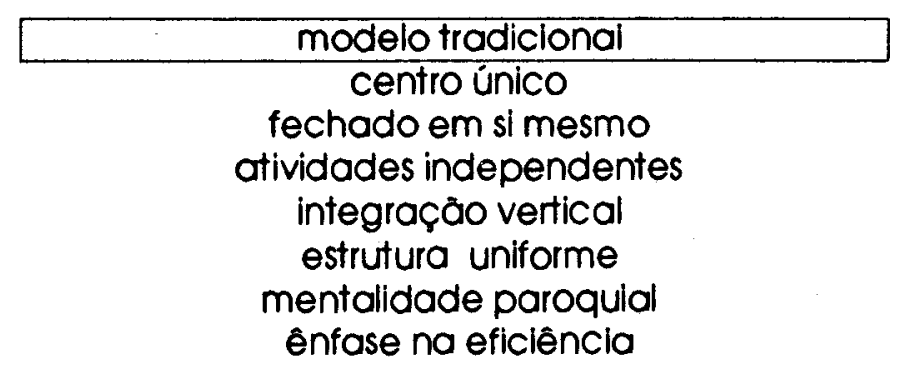

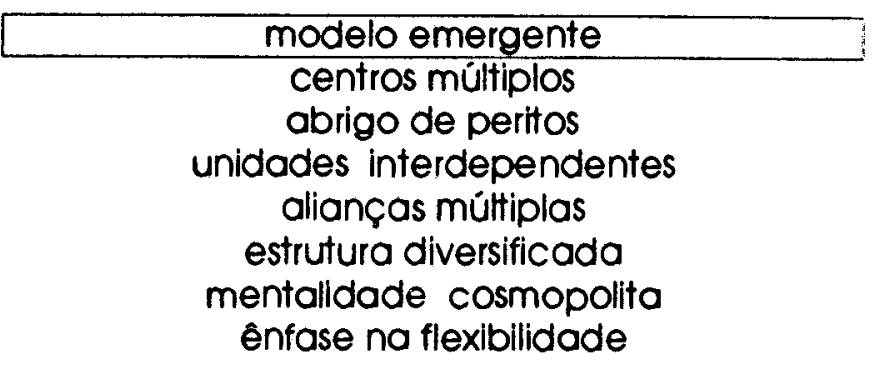

de forma a se adequarem ao rápido passo das mudanças tecnologicas, da competição mundial e da emergência de uma economia baseada no conhecimento (veja detalhes em [221]). Estes desenvolvimentos estão precipitando um afastamento das estruturas monolíticas e rígidas, criadas para engrenar transaçōes repetitivas e atividades rotineiras. O movimento resultante ocorre na direção de formas organizacionais flexíveis e ágeis, que possam acomodar novidade, inovação e mudança.

Este processo de metamorfose e transformação está ocorrendo principalmente em empresas de alta tecnologia que, frente a estas mudanças, estão promovendo experiências organizacionais inovativas, as quais se refletem nas seguintes tendências [6]:

- estrutura organizacional flexivel dividida em blocos: "equipes" ou "grupos" que são flexíveis rompem com as hierarquias e podem evoluir para acomodar todas as habilidades necessárias a um projeto ou a uma mudança de prioridades;

- organização multi-polar. semelhante a uma "federação" ou "constelação" de unidades de negócios que são interdependentes, precisando umas das outras para habilidades criticas e know-how;

- sistemas dualísticos: são estruturadose cáticos ao mesmo tempo, pois foram projetados para permitir um equilíbrio dinâmico entre estabilidade eflexibilidade;

- orientação para a linha de frente: a administração/gerência passa a se envolver em atividades de "linha de frente", como vendas, design e produção; - mentalidade cosmopolita: graças ao rápido processo de globalização da economia mundial, é necessário desenvolver uma mentalidadeque incorpore premissas e suposiçð̃es culturais diferentes;

- organizaçãobaseada em capacitaçãoe empregados multitalentosos: "nossos bens têm pernas; eles vão para casa todo dia" (Andrew Grove, presidente da Intel);

- fronteiras semi-permeaveis: baseando os negocios ea infraestrutura organizacional em torno de parcerias estratégicas.

De fato, a capacidade central das empresas de alta tecnologia é o seu know-how, o qual está presente nas pessoas. A organização pode, assim, ser caracterizada como uma montagem em rede de capacidades e relacionamentos individuais, ao invés deuma série de papéis e posiçð̃es pré-determinadas e relacionamentos formais hierarquizados 5 .

A chave para as mudanças organizacionais que estas empresas estão enfrentando parece estar no balanceamento (equilíbrio) entre diversas tensöes que se opóem: vender e oferecer produtos existentes, enquanto desenvolvem e colocam no mercado novos produtos; continuar disciplinada, com foco bem definido, enxuta, enquanto aprendem, experimentam e se recalibram continuamente; gerar consenso, garantindo lucro a curto prazo no contexto de uma visão a longo prazo. A moderna empresa de alta tecnologia precisa de diversas capacidades e de arranjos organizacionais multifacetados para lidar flexivelmente com estas complexas tensð̃es. Uma comparação entre os atributos organizacionais dos modelos tradicional e emergente pode ser vista no Quadro 1.1.
Quadro 1.1

Comparação entre os modelos organzaclonais tradiclonal $\theta$ emergente (ct. (6)).

5. Para uma descriçáo detathada de uma empresa - no caso, a Apple - onde estas tendênclas estăo se tornando uma realidade, veja (205). 


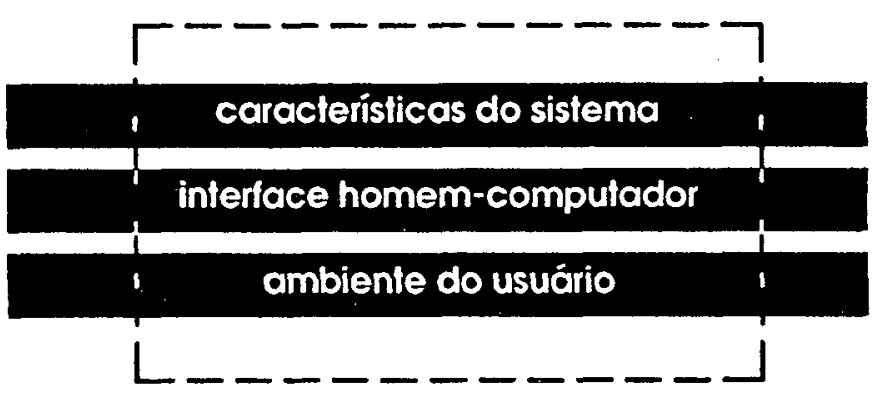

Figura 1.4

Partes de um sistema (ct. (45)).
Os atributos que caracterizam o tipo de organização que está surgindo estão fortemente apoiados na coordenação de uma vasta gama de fontes produtoras de conhecimento. O maior problema aparece justamente em como coordenar estas fontes: será para auxiliar estas atividades que a tecnologia da informação terá seus mais importantes usos e onde irá provocar os mais profundos efeitos ([139] e [206]). Para Austin Henderson, "na década de 90 os sistemas de informação precisarão ser construfdos a partir de várias perspectivas: para acomodar todas estas fontes produtoras de conhecimento precisaremos dar suporte à compreensão, colaboração, conflito e compromisso "([91] e [99]).

\section{O desenvolvimento de software: uma questão de design}

A indústria de software, praticamente desde seu início, tentou minimizar os problemas de desenvol vimento que se alastraram, tais como estouros de orçamento, atrasos na entrega, baixa performance do produto, e usuários insatisfeitos [45]. A maior parte do esforço dispendido concentrou-se no uso de métodos de desenvol vimento de um tipo ou outro que tentam fornecer uma estrutura para o desenvolvimento do software que impeça a proliferação de alguns ou de todos estes problemas.

Enquanto muitos vêem o desenvolvimento de software como um problema de engenharia, ele é, de fato, um problema de design, o que exige uma abordagem diferente. As metodologias que estão à venda foram feitas para resolver problemas de engenharia de software e são aplicadas erroneamente a problemas de design. Como exemplo, podemos dizer que escrever um parser para comandos é uma tarefa de engenharia (entradas e saídas bem definidas), mas determinar as funções de um aplicativo e construir uma interface (homem-computador) para estas funções, é uma tarefa de design (entradas e sádas mal definidas).

O parser fica invisível para o usuário final do sistema, enquanto a interface e suas capacidades estão sempre visíveis. É tarefa do engenheiro construir um parser que traduza cometamente os comandos para uma sintaxe interna; é tarefa do designer construir um aplicativo e sua interface de maneira que funcione como o usuário espera e se adeque corretamente ao seu ambiente de trabalho.

Se a tentativa é de minimizar os problemas de desenvolvimento e melhorar a comunicação entreengenheiros, designers e usuários, se faz necessária uma nova abordagem para o design de software. A equipe de desenvolvimento precisa estar consciente dos efeitos causados por um sistema sobre o usuário e seu ambiente. Isto significa mais do que simplesmente identificar os efeitos localizados sobre a performance na execução de uma tarefa; inclui, como sugerido nas seções anteriores, os efeitos causados sobre o ambiente de trabalho e sobre o comportamento social e organizacional do usuário.

Cohill [45] propõe que se divida um sistema em três partes distintas e separadas (Figura 1.4):

- Características do sistema. O hardware e o software necessários para implementar o sistema. Isto inclui processador central, discos de armazenagem, monitores, sistema operacional, código de aplicação de baixo nível, ferramentas opcionais como base de dados ou pacote de comunicação, e código específico do aplicativo. 


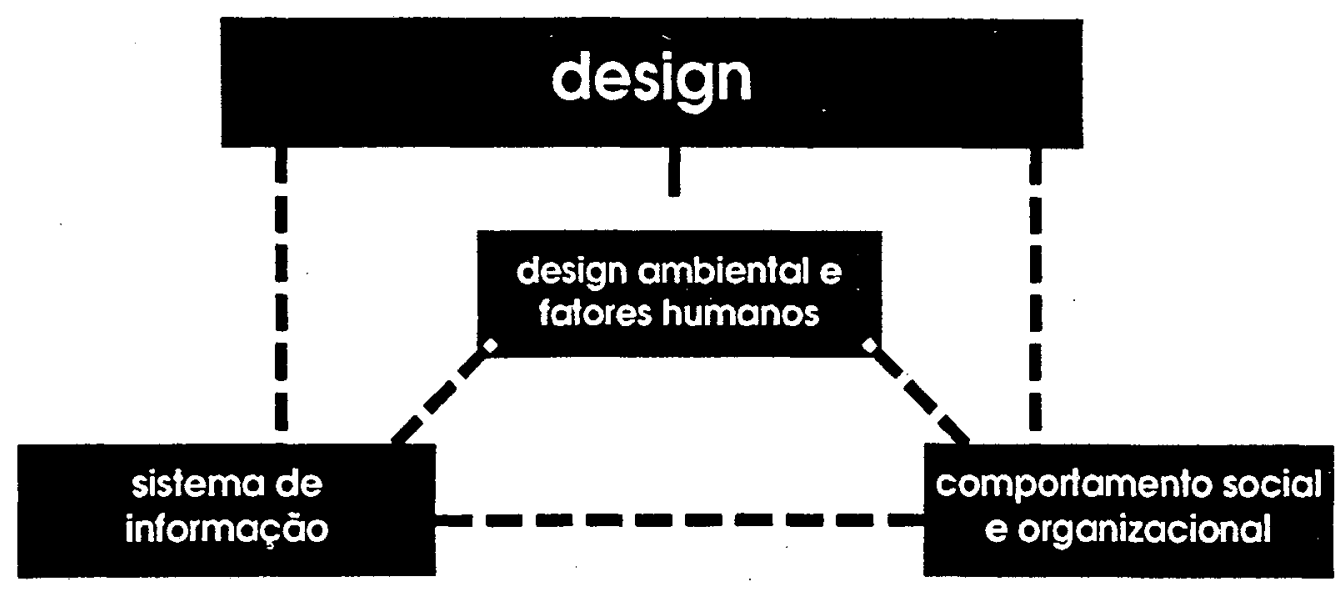

- Interface homem-computador. O software que implementa a interface com o usuário. Este software determina o estilo de interação com o usuário, os tipos de comandos disponiveis, o layout da tela, e pode afetar enormemente tanto a perfomance do usuário quanto a do sistema.

- Ambiente do usuário. As variáveis exógenas que podem afetar a aceitação do sistema pelo usuário e a performance individual. Isto inclui características físicas do ambiente como controle de temperatura, luz ambiente, edistribuição do espaço de trabalho. Igualmente críticos são os fatores como fluxo de informação, estruturas de poder da administração e as estruturas sociais informais do ambiente de trabalho.

Geralmente, as características do sistema recebem a maior parte da atenção porque a equipe de desenvol vimento possui o background necessário em ciência da computação e programação.

A interface muitas vezes recebe atenção inadequada porque sua construção é atribuida a programadores e analistas que, na maior parte das vezes, não possuem conhecimento sobre análise de tarefas, avaliação de performance humana, teorias de interação homem-computador, e modelagem cognitiva.

$O$ ambiente do usuário invariavelmente recebe pouca ou nenhuma atenção. $O$ engenheiro está qualificado para fazer recomendaçðes sobre o projeto do espaço de trabalho, controle de temperatura e iluminação, mas estes detalhes geralmente não são considerados como partes integrantes de um sistema de informação. Questões relativas a comportamento social no ambiente de trabalho são completamente ignoradas. A introdução de um sistema de informação muitas vezes altera e rompe tanto com os padrões formais quanto com os informais, mas raramente existe alguém qualificado para estudar o problema ou fazer recomendações a este respeito dentro da equipe de desenvolvimento.

Uma excelente analogia para esta situaçãoé a de se utilizar um encanador para projetar e supervisionar a construção de uma casa. É garantido que todos os banheiros estarão funcionando, mas quanto aos outros componentes da casa... Quando se constrói uma casa, procura-se um arquiteto, cuja formação básica á a de designer e que também possui bons conhecimentos sobre os diversos componentes de uma casa. Conhecimento suficiente para escrever especificaçðes de alto nível para o encanador e, ao mesmo tempo, deixar a implementação do sistema a cargo deste e de outros especialistas.

Em vez de possuir apenas uma estreita formação em produção de software ou fatores humanos, este "arquiteto" - ou designer — de sistemas deve possuir uma ampla educação cobrindo ambas as disciplinas e também experiência em comportamento social e organizacional. Esta idéia está esboçada na Figura 1.5.

Figura 1.5

Áreas de formacóo necessárias para um "arquilteto" da informaçáo (ct. (45)). 
Para contrastar a visão de desenvolvimento de software como um produto, adotada pela engenharia de software, com a visão de design, adotada explícita ou implicitamente em algumas formas inovadoras de desenvolvimento de software, apresenta-se a seguir as tendências básicas em metodologia da programação-e, por extensão, em engenharia de software - como elas evoluiram a partir de 1968, ano da primeira conferência a estabelecer um programa de pesquisa para a área.

A partir desta data um software é visto como um produto a ser manufaturado com base em requisitos fixos. $O$ desenvolvimento de software é comparado com outras formas industriais de produção, e utiliza um processo de produção igualmente transparente, independente de quem está desenvolvendo. As hipóteses básicas deste paradigma são [63]:

- O desenvolvimento de software está baseado em requisitos fixos. Estes podem ser determinados independentemente do contexto da aplicação ou obtidos através da análise do contexto utilizando-se técnicas formais de processamento de informação (diferentes instâncias de uma perspectiva de sistemas). - O desenvolvimento do produto software deverá ser dividido em fases temporais. O resultado de cada fase é um documento que é considerado tanto como um produto intermediário quanto como uma base para a próxima fase de desenvolvimento.

- A comunicação sobre o produto software deve, na medida do possível, ser feita exclusivamente com base nos documentos definidores. Estes precisam ser completos, consistentes e não ambígüos, e precisam definir o quê o programa deve fazer sem explicitar como isto deve ser feito.

- Os métodos tomam a forma de regras de trabalho, as quais especificam o significado das representações a serem utilizadas e prescrevem os passos do trabalho a ser realizado e a sequiência na qual ele deve ser realizado (por exemplo, design top-down, iniciando por um documento definidor que especifica a solução geral de uma maneira abstrata, precedido de um número de refinamentos ou passos de execução até que seja encontrada uma formulação completa do programa).

- O mais importante critério de qualidade é a assim chamada corretude do programa. Corretude significa que o programa funciona em conformidade com o documento definidor, sem que seja feita qualquer referencia ao contexto da aplicação. A corretude é alcançada através de procedimentos matemáticos e provas formais baseadas nestes procedimentos.

- O documento definidor deve, na medida do possível, ser escrito em uma linguagem formal, já que a linguagem natural não é confiável por causa de sua ambigüidade. Raciocinar em prosa comum $\hat{e}$, assim, menos significativo do que os modelos formais. A compreensão humana ocorre com base em regras a serem empregadas para uma interpretação não ambígüa dos modelos formais.

- Os seres humanos recebem subtarefas no desenvolvimento do software combase na estrutura do produto queé derivável dos documentos definidores. É sua tarefa desenvolver programas para solucionar corretamente o subproblema a eles entregue. $O$ estilo de trabalho dos seres humanos deve, na 
medida do possível, ser guiado por regras, não diferindo essencialmente do das máquinas. Sempre que for tecnicamente factível, as subtarefas de desenvolvimento de software devem ser realizadas pelo computador.

Éclaro que qualquer livro de engenharia de software admite abertamente que o desenvolvimento real de soft ware em situações de projeto individuais se afasta deste ideal. No entanto, os futuros cientistas da computação ainda são treinados predominantemente de acordo com este paradigma ${ }^{6}$. A principal desvantagem é que ele fornece uma base metodológica muito pobre para o design de tecnologia com preocupações sociais, porque não existe suporte para a comunicação e para os processos de aprendizado entre a equipe de desenvolvimento e os usuários. Além disso, nenhuma atenção é dada aos problemas de adequação do software ao contexto de aplicação e nenhuma consideração é feita do computador como uma ferramenta para a solução de problemas [62].

Deve ser notado que a tradição da engenharia de software, exposta rapidamente acima, está baseada em concepç̃es sobre como o desenvolvimento de software deve ser feito. Em outras palavras, estas concepçðes impð̃em de antemão regras especfficas de ação para a situação atual de desenvolvimento, regras que, de acordo com as hipoteses do paradigma, resultam na produção de software de alta qualidade.

Em contraste, as novas abordagens estão baseadas no desenvolvimento de software como realmente é feito (isto é, elas procedem a partir de experimentos reais de processos de desenvolvimento e de estudos empíricos sobre situações de projetos da vida real; por exemplo, veja [180]). Elas levam em conta os problemas e tarefas encontrados em sua totalidade, acreditando nos métodos apenas como auxiliares em beneffcio da equipe de desenvolvimento, permitindo um comportamento inteligente diante das situaçð̃es encontradas durante o desenvolvimento e a utilização de suas habilidades para produzir software de alta qualidade.

Diante deste ponto de vista, design significa o produto software, sua colocação no contexto social e seu processo de desenvolvimento. Portanto, a visão geral é a de que o processo de desenvolvimento do sistema tem uma considerável influência no produto final. Esta é a razão para o interesse em métodos de desenvolvimento de sistemas.

Desta forma, está senđo dada uma atenção cada vez maior ao desenvol vimento de programaspara (a) a estrutura social e de comunicação em organizações, e(b) os processos cooperativos de trabalho que precisam ser suportados. Está sendo feito um esforço consciente para combinar insights de várias disciplinas cientificas diferentes (por exemplo, teoria das organizaçóes, filosofia, psicologia e lingǘrstica) ${ }^{7}$.

Uma visão coerente de desenvolvimento de sistemas dirige sua atenção principalmente para formas significativas de cooperação entre membros de uma equipe de desenvolvimento e entre a equipe e os usuários, buscando a manufatura de produtos de alta qualidade técnica e o design de ambientes de trabalho que levem em consideração as necessidades dos usuários.

As principais características desta visão - identificar as atividades relacionadas com os processos que ocorrem, enfatizar sua correlação com as atividades relacionadas com o produto, e adeqüar a metodologia para dar suporte ao trabalho, à comunicação e aos processos de aprendizagem que ocorrem durante o desenvolvimento do sistema constituem uma significante contribuição para a compreensão do desenvolvimento e do design de sistemas baseados em computadores. Estes processos se apoiam, em particular, na cooperação entre equipe de desenvolvimento e usuários.
6. Para uma estudo sobre o curriculo dos cursos de compur taçao e as novas exigências em termos de formaçao para o mercado de trabalho e para apesquisa, veja (53) e.no caso específico da área de intertoce homem-computado? veja (227).

7. Para mals detalhes, veja (13), (9), (18), (32-33), (31), (50). (58), (90), (97), ( 112$),(130)$. (132). (134), (136), (153), (154), (17)174). (181). (185). (186). (197). (203). (213), (222) $\theta$ (226). 
Para esta abordagem, a idéia é que o usuário tem um papel crucial no desenvolvimento, instalação e uso da tecnologia da computação. Isto levou a uma redefinição do relacionamento entre a equipe de desenvolvimento e os usuários [81]. A partir de um bom número de projetos de desenvol vimento, foram testados vários conceitos de cooperação, e as técnicas tradicionais de participação (como, por exemplo, [127] e [159]) foram aprimoradas com a adoção dos seguintes princípios:

- Aprendizado mútuo. Usuários e equipe de desenvolvimento são expostos a um processo mútuo de aprendizado e comunicação.

- Projetar fazendo. Experimentação e testes desde o início, tais como usar prototipagem e promover comunicação e processos de aprendizado.

- Co-determinação. Governada pelos interesse de todos os grupos envol vidos no uso do sistema na concepção, design e controle de processos de trabalho baseados em computadores.

Todas estas considerações metodológicas podem ser vistas como incorporadoras de uma abordagem orientada a processos. Isto vai além da preponderante visão orientada a produto da engenharia de software e induz a uma reavaliação (a) do papel da equipe profissional de desenvolvimento de software, (b) da importância de formas desejáveis de cooperação e divisão do trabalho, e (c) da importáncia dos métodos e das ferramentas de suporte no desenvolvimento de software.

Em 1990, o comitê de padrões para a interação homem-computador da Human Factors Society inglesa criou uma distinção entre método e processo. Um método especifica o que se precisa para começar um projeto e o que se deve obter ao terminar. Um processoe uma instância de um método ou de um conjunto de métodos. Istoé, um método (por exemplo, um algoritmo) é estático, produz os mesmos resultados cada vez que é utilizado, enquanto um processo é dinâmico e pode chegar a resultados diferentes cada vez que é utilizado [45].

Métodos de desenvolvimento por si proprios não são inerentemente ruins; os problemas surgem quando a equipe de desenvolvimento tenta aplicar o mesmo método para uma grande variedade de situaçóes. Por outro lado, a abordagem de processos permite ao designer a liberdade de escolher métodos e ferramentas de desenvolvimento heuristicamente, aplicando-as e usando-as conforme a necessidade aparecee de acordo com sua adequação a uma situação em particular.

Esta abordagem procura elementos descritivos e prescritivos. Para isso, precisa se ocupar com o desenvolvimento e o uso de sistemas de computadores, com a natureza e o escopo das abordagens cientfficas para estudar estes sistemas, e com conceitos para combinar insights de diferentes perspectivas cientificas.

Em um artigo de 1986, Krysten Nygaard [176] caracteriza a informática - termo que ele prefere a "ciência da computação" - como "a ciência que tem como domínio os processos de informação e os fenomenos relacionados a artefatos, na sociedade e na natureza". Para ele, "um processo é visto como um processo de informação quando as qualidades consideradas são: sua substância, a matéria física que ele transforma; as propriedades mensurâveis de sua substância, representadas pelos valores e transformações de sua substância e assim de suas propriedades mensuráveis. Os mais importantes processos de informação, em nosso atual contexto, seriam as execuções de programas e o processamento de dados realizados em conjunto por computadores e pessoas'. Os 
fenómenos relacionados incluem elementos como as ferramentas disponfveis, o desenvolvimento de sistemas e programas, os processos de aprendizado e de trabalho que ocorrem, assim como os limitantes que atuam sobre eles.

A definição de informática dada por Nygaard, como ele mesmo ressalta, não é compatível com outras definiçð̃es que veêm a informática como uma disciplina formal, semelhante, por exemplo, à matemática. Ao contrário, sua definição é similar às que se aplicam a ciências como botânica, física, sociologia, todas relacionadas com aspectos selecionados de classes específicas de fenômenos. Ciências definidas desta forma possuem quatro aspectos (compare com os golfos de Norman):

- Fenomenologia. O estudo empírico dos fenômenos (veja [220]).

- Análise. Compreensão e explicação dos fenômenos em termos de uma teoria subjacente (veja [85]).

- Síntese, construção e tecnologia. Conhecimento organizado como propósito de interferir em, construir ou gerar fenómenos.

- Reflexão multiperspectiva. A consideração e o exame de conceitos e fenómenos ao mesmo tempo (ou alternadamente) a partir de perspectivas de mais de uma ciência ou a partir de mais de uma perspectiva dentro da mesma ciência (veja [133]).

Nygaard sugere, então, a adoção de múltiplas perspectivas no domínio da informática, e enfatiza que a capacidade de reflexão multiperspectiva é essencial para cada profissional da área. Fica claro que perspectiva é um conceito chave na informática. $\mathrm{Ny}-$ gaard define perspectiva como: uma parte do universo cognitivo que pode estruturar seu processo cognitivo quando se reportar a situações dentro de algum domínio [65]. Podemos classificar o conceito de perspectiva em informática de acordo com as seguintes linhas:

- a adoção de perspectivas no contexto de desenvolvimento de projeto;

- o significado das perspectivas em conexão com os métodos da informática;

- a consideração do domínio da informática a partir da perspectiva de diferentes disciplinas cientificas;

- a valorização da adoção de perspectivas no desenvolvimento tecnológico com o objetivo de alcançar metas socio-políticas específicas.

No próximo capítulo, são apresentadas algumas das perspectivas discutidas na literatura. 


\section{Perspectivas para o design de sistemas e de interfaces}

A Renascença fez mais do que modificar a visdo que as pessoas tinham do mundo. Ela literalmente inventou a perspectiva. Pela primeira vez, o ponto de vista passou a existir.
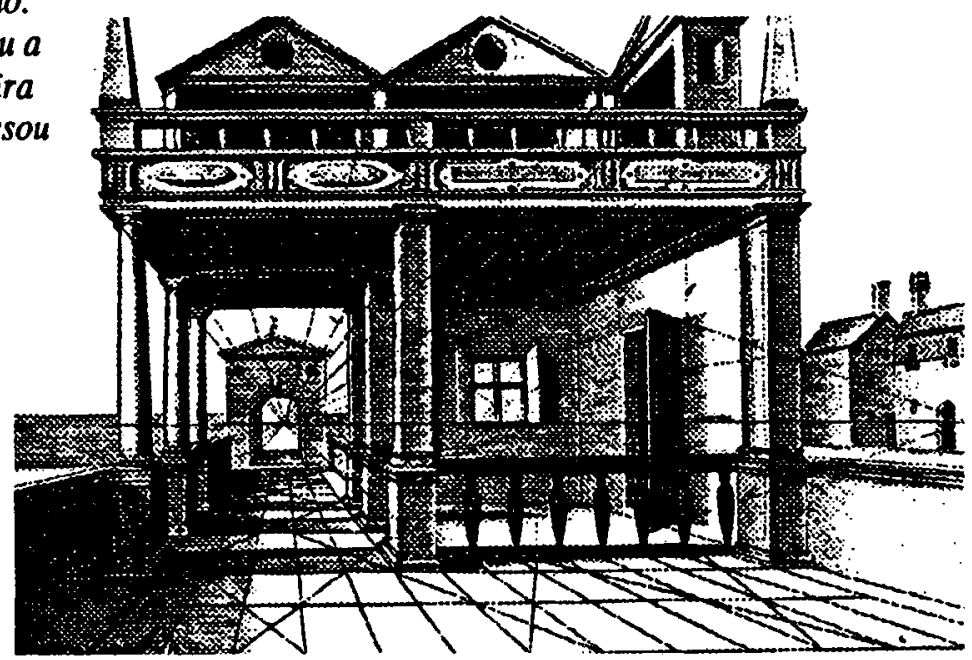
A utilização do conceito de perspectivas no design de sistemas e de interfaces permite que o contexto social e cultural onde se está atuando seja melhor compreendido. A importância desta abordagem para o desenvolvimento de software fica evidente em trés artigos da literatura recente da área: (1) o de V. J. Symons [217], que aplica o conceito a nfvel teórico em sistemas de informação; (2) o de R. Hirschheim \& H. K. Klein [94], que apresenta a idéia a partir de exemplos expressivos de sistemas utilizados em empresas; e (3) o de J. Kammersgaard [104], que se preocupa com a aplicação do conceito na construção de interfaces.

Como o tratamento de cada um dos artigos enfatiza um aspecto da aplicação do conceito de perspectiva, a apresentação de cada um será feita separadamente, sem que exista a preocupação de estabelecer uma comparação entre eles. O objetivo desta escolha é mostrar como os artigos se complementam, reforçando a importância de se utilizar o conceito tanto a nível de sistema de informação quanto a nível da interface com o usuário.

\section{Sistemas de informação e contexto}

De acordo com Symons, podemos analisar o desenvolvimento de sistemas de informação a partir dos impactos causados pelas premissas assumidas por cada uma de qua-tro perspectivas: a determinista, a mecanicista, a de sistemas, e a interacionista (veja Quadro 2.1).

Perspectiva determinista. De acordo com esta visão, o impacto dos sistemas de informação (SIs) sobre indivíduos, organizações e sociedade é função apenas da própria tecnologia: os efeitos da introdução de um SI são determinados exclusivamente pelo tipo de hardware, software e telecomunicações envolvidos.

Odeterminismo tecnologico geralmente assume duas formas: uma otimista e outra pessimista. A otimista apóia a visão promulgada pela imprensa da área de informática, garantindo que, se um SI for instaladoem uma organização, oefeito será espetacularmente benéfico e imediato. Os beneficios aparentemente rápidos de serem obtidos são alta produtividade, eficiência, novas oportunidades de emprego, aprimoramento da comunicação e melhor qualidade de vida. Toda nova tecnologia é enaltecida como um exemplo de progresso; uma "boa coisa" per se.

O pólo oposto desta visão é o pessimismo. Seus proponentes apresentam a introdução de uma nova tecnologia como sendo inevitavelmente acompanhada por amplo desemprego, descaracterização do trabalho, aumento na centralização do poder, e diminuição da liberdade e privacidade individuais. As automaçōes de escritórios e de fábricas são emblemas das consequências desastrosas para a satisfação no trabalho e para a qualidade do trabalho em geral.

O meio termo entre otimismo e pessimismo se preocupa com os critérios para a utilização de maneira apropriada de tecnologias "de sucesso" e "aceitáveis". Várias perspectivas possuem esta visão. Uma das mais influentes é a abordagem mecanicista.

Perspectiva mecanicista. Praticamente tudo, a partir desta perspectiva, pode ser visto como uma máquina. Estas máquinas são compostas por partes interligadas que possuem um papel especificamente definido no funcionamento do todo. Devem, como as máquinas, se comportar de uma maneira confiável, padronizada e previsf́vel. Suas operaçóes 
A abordagem mecanicista possuj fortes ligações com a teoria dos sistemas fechados. O estudo de sistemas foi desenvol vido como resposta à necessidade de se lidar com fenômenos complexos: os problemas que envolvem muitas variáveis interligadas não são obrigatoriamente passíveis de redução a conexões entre componentes individuais, mas exigem uma consideração do funcionamento do sistema como um todo. A teoria dos sistemas fechados estabelece uma fronteira de estudo como sendo os limites de algo organizado. $\mathrm{O}$ ambiente externo é excluído da análise dentro do sistema, a ênfase está na eficiência das transformaçóes de entrada e de sarda.

Muitas das criticas a esta abordagem estão centradas na suposição de que 0 ambiente onde o sistema está imerso é fixo e imutável, e, portanto, pré-determinado para estudo. A teoria de sistemas abertos, por outro lado, trata o sistema sob consideração como sendo sensível à sua circunvizinhança. A idéia de um sistema em ativo relacionamento com o ambiente é, obviamente, fácil de ser aplicada ao campo da análise organizacional.

Perspectiva de sistemas. A teoria de sistemas está baseada na idéia de que entidades possuem propriedades que não são propriedades de nenhum constituinte individual: 0 todo é maior do que a soma de suas partes. O todo é concebido como um "sistema", com uma coerência interna que torna aceitável traçar uma fronteira que o diferencie de seu ambiente. A existência desta fronteira define como "entradas" ou "saídas" qualquer coisa que ultrapasse a fronteira. Qualquer sistema é, pelo menos potencialmente, um membro de uma hierarquia composta por entradas e sádas - ele pode conter subsistemas e ser ele mesmo parte de um sistema maior. A manutenção de uma hierarquia de sistemas abertos ao seu ambiente incorpora um conjunto de processos no qual a informação circula com o proposito de regulação ou controle. Assim, a eficácia de um SI é função de quão bem adaptado ele está ao ambiente com o qual interage. A teoria de sistemas possui um enorme valor e importância para o estudo de SIs, e várias linhas de pesquisa autilizaram como base para seu desenvolvimento.

Uma destas linhas é a que define a escolha de um método, formato ou procedimento para o projeto de um SI como contingência das caracteristicas do problema ou da situação. No entanto, as organizaçães parecem resistir a qualquer categorização que produza guidelines robustos para a construção de SIs. Geralmente, estes sistemas apresentam características perturbadoramente diferentes, apesar das aparentes similaridades quanto a tarefas, estruturas e ambiente. Os elementos sociais são o destaque como fatores determinantes.

A segunda maior linha, a teoria sócio-técnica, procura levar em conta estes elementos sociais. Desenvolvida a partir de uma crescente preocupação de que os aspectos humanos estejam sendo neglicenciados, esta abordagem tenta otimizar tanto os aspectos técnicos quanto os sociais de um sistema de trabalho. Esta visão encoraja o surgimento de alternativ as para a organização burocratizada. Seu objetivoé o de aumentar a produtividade $\mathrm{e} o$ aprendizado através do aumento da participação das pessoas envolvidas na tomada de decisðes e no controle individual sobre 0 ambiente de trabalho [17]. A abordagem participativa enfatiza a importância da integração entre todas as partes do sistema.

Os princípios utilizados pelo design sócio-técnico foram aplicados de maneira satisfatória na compreensão do impacto dos SIs, principalmente na Europa e nos EUA. Land e Hirschheim [127] discutem o raciocínio por detrás do design participativo de 
sistemas e listam algumas ferramentas e técnicas utilizadas. A participação dos envolvidos no processo de design leva a um aumento na motivação e identificação com o sistema, o que gera, segundo estes autores, alta produtividade e eficiencia no trabalho.

A teoria sócio-técnica geralmente é aplicada do ponto de vista gerencial/administrativo. Participação apenas não é suficiente: os usuários precisam ser capazes de influenciar o processo de design, isto é, eles precisam ter poder. Esta questão levou, por exemplo, ao desenvolvimento da abordagem escandinava chamadade recursos coletivos para design de sistemas. Baseada nos prinćpios sócio-técnicos de design, a principal diferença reside na intensa participação dos sindicatos profissionais, o que permitiu a evolução para uma estreita colaboração entre pesquisadores e sindicalistas. A premissa subjacenteé a de que o design de sistemas não pode ser realmente participativo antes que todas as partes envolvidas no processo possuam todo o (mesmo) conhecimento do que é possivel ser obtido como prováveis saŕdas do sistema. A abordagem de recursos coletivos enfatiza o impacto dos SIs na distribuição de poder e conhecimento dentro de uma organização.

O verdadeiro design participativo requer que os gerentes/administradores, programadores/designers sejam confrontados com as perspectivas dos trabalhadores. Desenvolvimentos recentes enfatizam os aspectos "soft", qualitativos, além do uso de perspectivas múltiplas. A abordagem de sistemas "soft" é um híbrido entre a tradicional teoria de sistemas e uma metodologia mais interpretativa, uma que leve a sério as diferenças de ponto de vista entre os envolvidos em uma dada situação de trabalho (para detalhes, veja [41]).

Perspectiva interacionista. Nos últimos anos o debate sobre estas questões sofreu uma alteração de rumo em suas atenções, quando as discussões passaram de:

- automação para interação homem-computador;

- uma concepção de SI como ferramenta do pensamento para uma de sistema como padrões de relacionamento social;

- uma confiança na racionalidade dos participantes no desenvolvimento do sistema para uma compreensão da importância da política organizacional; - uma preocupação com redução de custos para uma preocupação com os valores adicionados e os benefícios organizacionais.

Esta alteração está associada ao desenvolvimento da abordagem interacionista, que considera os efeitos de um SI como sendo um produto não apenas dos aspectos técnicos ou organizacionais, mas também de sua interação.

O desenvolvimento desta abordagem é alimentado pelo debate sobre a natureza da informação. Os impactos problemáticos dos SIs se devem em parte a uma inadequada compreensão da informação e de como ela é utilizada organizacional e socialmente. Basicamente estas "incompreensões" são oriundas das perspectivas deterministas, mecanicistas ou de sistemas fechados. Mason e Mitroff [144] argumentam que a teoria e a prática dos SIs foram reprimidas por um conceito de informação mal definido filosoficamente. Para estes autores, "informação não é simplesmente feita de dados, mas sim o resultado de uma interpretação destes dados". O valor da informação fornecida por um SI, então, é determinado por seu significado e por sua utilização. A pressuposiçăo que 
está por trás desta afirmação é a de que os indivíduos atuam de acordo com o significado que atribuem às situações das quais participam. $O$ impacto de um SI não pode ser avaliado dissociando-o do significado que seus usuários tenham atriburdo ao sistema.

Esta maneira de olhar para a informação enfatiza o significado como um produto da interaçăo entre dados $e$ as pessoas que os usam. Assim, a abordagem interacionista deve ser aplicada não apenas à relação entre tecnologia e organização, mas também aos significados partilhados e negociações que constituem as relaçôes sociais que se estabelecem ao redor de um SI. Como muitas das dificuldades no desenvolvimento e operação de um SI estão relacionadas com os "problemas humanos", a literatura apresenta, nos últimos anos, um aumento considerável de artigos que enfatizam a importância dos impactos sociais dos SIs. Um pequeno mas cada vez maior grupo de pesquisadores rejeita a noção de que se possa fazer uma clara distinção entre os aspectos técnicos e os sociais ${ }^{1}$. Para este grupo, 0 impacto de um SI sobre os relacionamentos sociais e organizacionais é tão profundo e de alcance tão amplo, que os efeitos sociais são separáveis dos técnicos apenas analiticamente; por esta razão os SIs são melhor conceitualizados como sistemas sociais nos quais a tecnologia é apenas um dos componentes -importante, sem dúvida, mas não o único. Onde os mecanicistas veêm um processo técnico e a abordagem sistêmica encontra consequiências comportamentais, este grupo de interacionistas vê o desenvolvimento de um SI como um processo social baseado na tecnologia. Mumford [158-161] acredita que são várias as implicaçõos para o uso de uma atividade consciente de design, encarando-o como um conjunto de atividades humanas interligadas e intencionais. Lyytinen et al. ([1-3], [131], [134], [136-137]) consideram como o desenvolvimento de um SI afeta um escritório, por exemplo, tanto no aspecto de sistema de atividades humanas quanto no de comunidade social: como conversações, interaçð̃es espontâneas, relacionamentos sociais, cultura, tradição epolítica são modificados em um ambiente de trabalho.

Ouso de computadores varia entre diferentes grupos sociais de acordo com os propósitos de seus integrantes, mas não é definido por eles (as conseqüências inesperadas de uma ação têm que ser levadas em conta). Rob Kling, citado por Symons, afirma que "a tecnologia é maleável, mas nãoé inteiramente plástica". Os SIs estão imersos em uma matriz (veja, por exemplo, [190]) de relaçóes sociais e econômicas que depende de uma infraestrutura local de recursos físicos, financeiros e humanos. Na verdade, os SIs podem ser melhor conceitualizados como complexos objetos sociais limitados (epermitidos) pelo seu contexto, infraestrutura e história.

Assim, do ponto de vista da abordagem interacionista, as conexões entre uso de computadorese algum tipo de resultado social, seja ele desejável ou não, são enfraquecidas pelas condiçð̃es e limitaçóes de seu contexto. A rede de relacionamentos sociais, processos de comunicação, e informação que flui em torno da tecnologia, da interação entre os participantes, eda diversidade de suas percepções, são fundamentais para a compreensão de como um SI funciona em qualquer tipo de organização. Os impactos de um SI são inseparáveis de seu contexto organizacional e social.

\section{Pressuposiç̋es sobre o desenvolvimento de Sls}

Cada uma das perspectivas apresentadas provoca suas próprias conseqüências para os impactos em um SI. Muito da prática e da pesquisa nesta área se apoia nas abordagens determinista, mecanicista e sistêmica. Estas perspectivas parecem ser
1. Veja. por exemplo. (21), (92). (95). (113), (133), $\theta(134)$. 
design cooperativo: o papel do designer e do usuário na construçóo de interfaces

inadequadas para o desenvolvimento de SI, e têm dado base para técnicas empobrecidas de trabalho simplesmente para suprir as necessidades econômicas imediatistas da sociedade da informação.

Todas as pessoas envolvidas no desenvolvimento de um sistema encaram esta tarefa com um certo número de pressuposiçóes explícitas e implícitas sobre a natureza das organizações humanas, sobre a natureza das tarefas de design, e sobre o que se espera dos designers de sistemas. Estas pressuposiçôes têm um papel central como guia do processo de desenvolvimento de SIs. É interessante, neste ponto, examinar os tipos de pressuposiçð̃es implícitas feitas durante este processo. Dependendo das pressuposições adotadas, podem ser identificadas diferentes abordagens para o desenvolvimento de SIs, o que caracteriza a produção de diferentes tipos de sistemas.

Especificamente, é fundamental destacar que a evolução das pesquisas na área indica, como apontam Hirschheim e Klein [94], que:

“(1) apesar da existência de uma abordagem ortodoxa para o desenvolvimento de sistemas, foram desenvolvidas recentemente alternativas que estão baseadas fundamentalmente em diferentes conjuntos de pressuposiçð̃es; (2) estas pressuposiçóes lidam principalmente com as atitudes adotadas acerca da realidade e do modo para se obter conhecimento sobre ela; (3) estas pressuposiçoes são feitas tanto explicita quanto implicitamente ao se adotar uma particular abordagem de desenvolvimento; (4) as formas pelas quais os objetivos dos sistemas são legitimados estão diretamente relacionadas com a abordagem adotada; (5) importantes consequiências sociais resultam da aplicação de uma particular abordagem."

O conjunto de pressuposiçøes fundamental adotado por uma comunidade profissional - o que permite que seus membros partilhem percepçoes semelhantes e adotem práticas coletivamente aceitas - é chamado de paradigma (veja [122]). Geralmente, um paradigma consiste de pressuposiçð̃es sobre o conhecimento e como proceder para adquirf-lo, e também sobre o mundo físico e social. Como os designers têm a tarefa de fazer indagações como parte do design do sistema, e têm que intervir no mundo social como parte da implementação do sistema, é natural que se faça uma distinção entre dois tipos relacionados de pressuposiçôes: aquelas associadas à maneira pela qual os designers adquirem o conhecimento necessário para projetar o sistema (pressuposições epistemologicas), e aquelas que estão relacionadas com a visão dos designers sobre o mundo social e técnico (pressuposiçōes ontologicas).

Os dois tipos de pressuposições sobre conhecimento (epistemológica) e sobre o mundo (ontológica) podem ser mapeados em duas dimensões: uma, subjetivismo-objetivismo; outra, ordem-conflito. Na primeira dimensão, a posição objetivista significa aplicar modelos e métodos derivados das ciências naturais no estudo das açб̃es humanas; isto significa tratar o mundo social como se fosse o mundo natural. Na outra ponta do eixo, a posição subjetivista questiona a propriedade de se usar os métodos das ciências naturais para estudar o mundo social e procura compreender os fundamentos do viver humano, aprofundando-se na experiência subjetiva dos indivíduos; sua principal preocupação é compreender a maneira pela qual um individuo cria, modifica e interpreta 0 mundo no qual se encontra. Na dimensão ordem-conflito, a visão de ordem (ou integracionista) enfatiza a existência de um mundo social que pode ser caracterizado por ordem, 


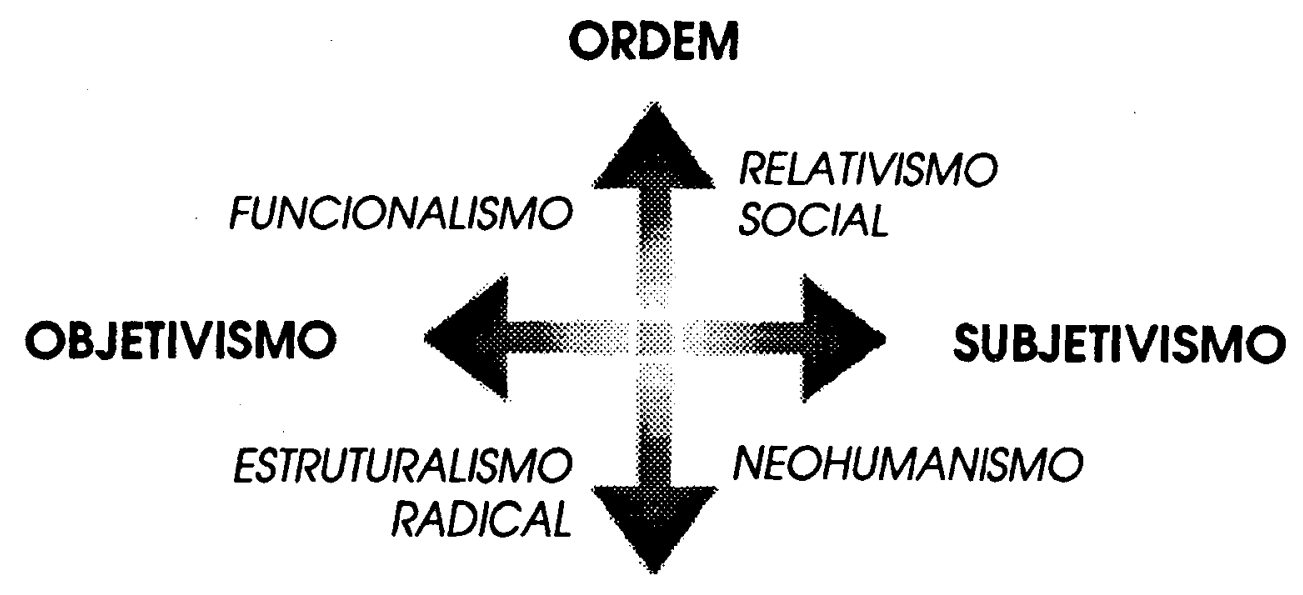

\section{CONFLITO}

estabilidade, integração, consenso e coordenação de funçães. A visão de conflito (ou de coerção) destaca a importância de mudança, conflito, desintegração e coerção. Quando estas dimensões são colocadas em um mesmo plano, obtemos quatro perspectivas para este domínio (veja Figura 2.1): funcionalismo (objetivismo-ordem), relativismo social (subjetivismo-ordem), estruturalismo radical (objetivismo-conflito), e neohumanismo (subjetivismo-conflito) [94].

A perspectiva funcionalista está preocupada em fornecer explicações sobre status quo, ordem social, integração social, consenso, satisfação de necessidades, eescolha racional. Ela procura explicar como os elementos de um sistema social interagem para formar um todo integrado. A perspectiva relativista social busca explicaçōes dentro do domínio da subjetividade e da consciência individuais, e dentro do quadro de referência do indivíduo social em oposição ao observador da ação. Deste ponto de vista, os papéis e as instituições sociais existem apenas como expressão dos significados que o homem atribui ao seu mundo. A perspectiva estruturalista radical enfatiza a necessidade de se transcender as limitações existentes nos arranjos sociais e organizacionais. Seu foco principal está na estrutura e na análise das relações económicas do poder. A perspectiva neohumanista busca mudanças radicais, emancipação e desenvolvimento das potencialidades humanas, e destaca o papel que diferentes forças sociais e organizacionais têm na compreensão das mudanças. Sua atenção está centrada em todas as barreiras para a emancipação - em particular, na ideologia (vista como comunicação deturpada, distorcida), no poder e nas restriçбes sociais e compulsð̃es psicológicas - e busca formas de superá-las.

Estas perspectivas são bastante implícitas e estão profundamente enraizadas na rede de crenças de bom-senso e no repertório de conhecimentos que servem como uma "teoria da ação" implícita para os seres humanos. Existe uma sobreposição das suas diferenças; elas funcionam como arquétipos - imagens simplificadas, mas concepçð̃es poderosas de tipos ideais. Estes tipos ideais não existem como entidades reais, mas exibem propriedades (em maior ou menor escala) que podem ser encontradas em entidades existentes, o que fornece significado para os arquétipos. Os arquétipos refletem as diferenças essenciais que existem em concepçõese abordagens alternativas para o desenvolvimento de sistemas.

Perspectiva funcionalista. Esta perspectiva evoluiu consideravelmente através dos anos (veja [179]) e se tornou uma fonte para vários sistemas de sucesso. Ela sugere que todo sistema de informação é criado para contribuir em fins especificos. $O$ papel da gerência/administração na organização é o de líder de grupo que conhece os fins que,
Figura 2.1

Dimensóes gerodas pelos tipos de pressuposiços sobre o conhecimento (cf. (87)). 


\begin{tabular}{l} 
Principals envolvidos \\
\hline Narrativa \\
\hline Roteiro
\end{tabular}

Pressuposiçðes

\section{Quadro 2.2}

Elementos que compóem o arquétipo funcionalista.
Administrador, pessoa que desenvolve e usuário.

Os sistemas de informaçáo sáo desenvolvidos para apoiar uma operacionalidade organizacional racional e uma administraçao de projetos eficaze eficiente.

Buscar o ideal da maximização do lucro.

Epistemológica. É a do positivismo, na qual o desenvolvedor obtém conhecimento sobre a organização procurando por relações de causa e efeito mensuráveis:

Ontológica. É a do realismo, a partir da crença de que existe uma realidade organizacional empirica que é independente do observador.

por sua vez, são traduzidos e especificados em termos de objetivos para o sistema. $O$ pressuposto geral é o de que a especificação é tão objetiva quanto possível. A decisão sobre questões polêmicas associadas a estes objetivos é vista como prerrogativa da gerência/administraçãoe normalmente não faz parte das atribuições de quem desenvolve (veja Quadro 2.2). Como resultado, os fins podem ser vistos como sendo partes isoladas, usadas em um conjunto, e objetivas. É claro que quem está desenvolvendo lida com vários tipos de conflitos, mas as ferramentas e os métodos usados se preocupam apenas com a escolha dos meios adequados para atingir os fins especificados, e não com a natureza dos fins últimos do sistema.

O papel principal do analista é o de ser um especialista em tecnologia, ferramentas e métodos de design de sistemas, e administração de projetos. A utilização deste ferramental permite que o desenvolvimento de sistemas seja mais formal e racional, depositando menor confiança na intuição, julgamento e políticas humanas.

Assim, para estaperspectivaexiste uma realidadequeé mensurável eessencialmente a mesma para qualquer pessoa. Opapel da equipe de desenvolvimento é o de criar sistemas que modelem esta realidade de maneira a transformar o sistema em uma ferramenta útil para a gerência/administração alcançar seus fins. Em princípio, estes fins coincidem com as metas organizacionais.

Segundo esta perspectiva, a realidade econômica se torna mensurável - através do conceito de requisitos econômicos - a partir de um nivel de qualidade pressuposto, semelhante ao encontrado na natureza. Esta realidade - traduzida em metas quantitativas e financeiras, e em características de performance do sistema - permite que os objetivos do sistema sejam obtidos de uma forma objetiva, verificável e racional. $O$ design de um sistema torna-se fundamentalmente um processo técnico.

A perspectiva deste especialista-em-sistemas-como-responsável-pelo-desenvolvimento, através da ênfase que coloca em diversas formas de modelagem, restringe sua atuação a captar a ordem subjacente dos domínios nos quais os participantes operam. Neste procedimento, assume-se que existam leis gerais ou padróes regulares que podem auxiliar a explicar e predizer a realidade. O procedimento estipulado busca capturar estas leis ou padróes, identificando as principais relações e aspectos organizacionais em um SI que permitam a auto-orientação dos participantes para que atinjam seus objetivos. Isto simplifica uma realidade complexa, tornando a vida organizacional mais racional. Racionalidade, neste caso, significa escolher os melhores meios para atingir determinados fins (por exemplo, maximizar eficácia e eficiência).

A abordagem para o desenvolvimento de sistemas sugerida por esta perspectiva tenta seguir o método cientifico. Isto explica sua clareza e compreensibilidade, e a torna amplamente aceita em uma grande comunidade. Além disso, ela auxilia na operacionalização de questões nebulosas e direciona os esforços no sentido de encontrar soluções técnicas produtivas. 
Duas crenças parecem estar por trás desta abordagem. A primeira é a de que quem desenvolve tem um papel neutro e objetivo durante o desenvolvimento do sistema, o que permite esclarecer as implicações de outras opções aiternativas de design. A segunda é a de que, desta maneira, pode-se deixar de lado as questões relativas a poder, interesses conflitantes e metas do sistema, afastando-as do domínio de quem desenvol ve sistemas.

No entanto, as pressuposiçð̃es associadas a esta perspectiva podem levar a um certo número de condições que contribuem para o fracasso do sistema. Por exemplo, a ênfase básica está na pesquisa sobre como usar os meios sem discutir os fins que se quer atingir. Isto pressupoe implicitamente que exista consenso sobre os fins especificados. Mas, na verdade, os fins são controversos e sujeitos a consideráveis desacordos e debates. Hoje, existem grandes dúvidas sobre a idéia de que as leis económicas governam as relações sociais de maneira similar as leis naturais e o universo físico. Pelo contrário, acredita-se que as relações econômicas são governadas por convenções sociais e pelas decisð̃es de uma poderosa elite sócio-política.

A reação mais comum à erosão destas crenças se reflete na resistência à mudança apresentada pelos usuários finais. Para evitar esta reação, quem desenvol ve sistemas têm confiado em uma série de abordagens, jogos e estratégias. Estas tentativas, no entanto, apenas perpetuam a noção de que o desenvolvimento e a implementação de um sistema representam um tipo de jogo. A pressuposi ção de que os objetivos do sistema são legítimos e de consenso continua existindo.

As duas pressuposições essenciais do funcionalismo - (1) que existe uma realidade empírica objetiva e que os métodos positivistas são a melhor forma de dar sentido a esta realidade; e (2) que a natureza do mundo social pode ser melhor concebida em termos de uma ordem integrada ao invés de pelos conflitos - são consideradas como sendo as mais problemáticas. Muitos ainda argumentam que o funcionalismo não foi particularmente bem sucedido na compreensão da vida organizacional e social, já que o assunto de estudo - as pessoas - não se coloca facilmente à disposição de um estudo através de instrumentos positivistas (veja [21], [92], e [113]). As pessoas têm vontade própria (livre arbítrio?) e a observação não pode ser considerada como neutra. As pessoas - enquanto objeto de estudo - tendem a "observar de volta": elas percebem o plano de ação do observador e contra-atacam com seu proprio plano.

Existe, assim, uma consciência da natureza mutável da realidade organizacional com a qual se defronta quem desenvolve. É explicitamente reconhecido na literatura que, em qualquer ponto no tempo, um sistema pode, na melhor das hipoteses, apenas se aproximar dos requisitos em constante modificação que surgem apartir dos deslocamentos nas tendências e políticas da vida organizacional, a qual nunca será totalmente conhecida por quem desenvolve.

Perspectiva relativista social. A segunda perspectiva surgiu recentemente (conforme [41], [117], e [119]). Ela é parcialmente umareação à primeira e de muitas maneiras seu oposto. Ela reconhece que o conhecimento sobre os meios e fins humanos não é facilmente obtido porque arealidade ex extremamentecomplexaeilusoria. Segundo Hirschheim \& Klein [94], "ñ̃o existe uma única realidade, apenas diferentes percepçð̃es sobre ela; ninguém possui uma fonte privilegiada de conhecimento, todos enxergam partes diferentes." Além disso, o papel que as pessoas desempenham na formação da realidade não 
design cooperatlvo: o papel do designer e do usuário na construçơo de interfaces

Principais envolvidos

Roteiro

Pressuposiçoes

\section{Quadro 2.3}

Elementos que compoem o arquétipo relativista social.

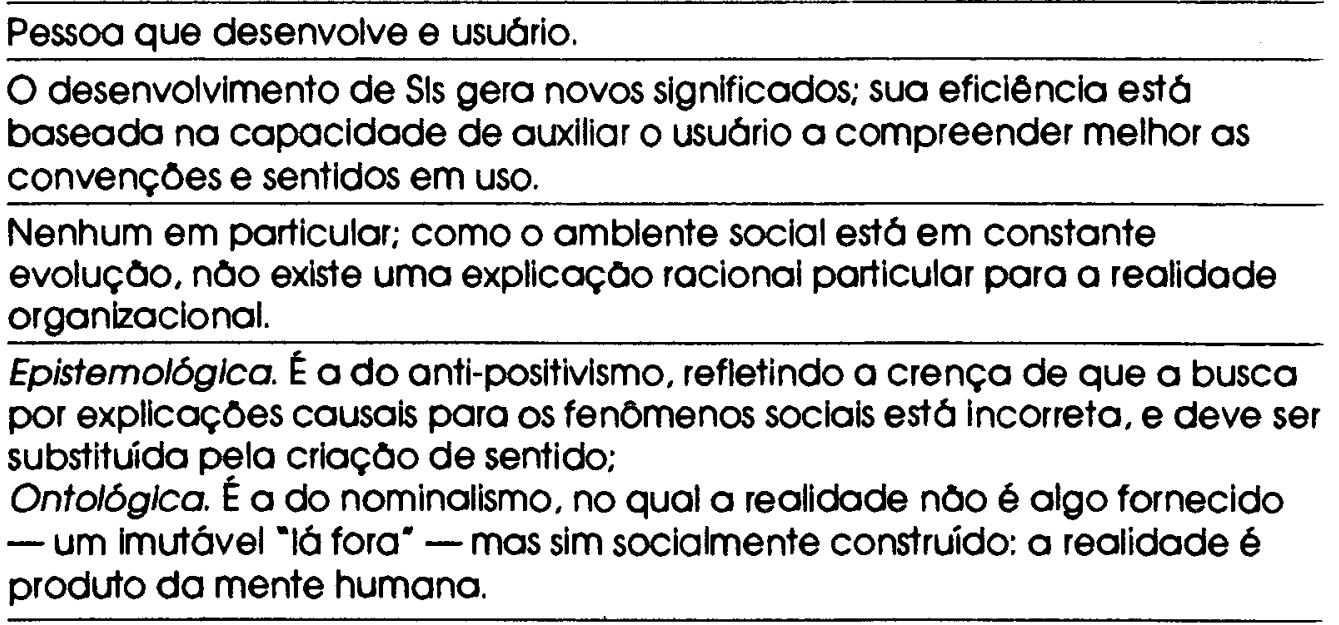

é muito claro. O que elas experimentam subjetivamente como uma escolha intencional de ação, pode ser simplesmente uma reação induzida por hábitos culturais ou por circunstâncias (veja Quadro 2.3).

Por esta razão, os objetivos de um sistema surgem como parte da construção organizacional da realidade, o chamado processo de construção de sentido [13].Para chegar a um consenso ou aceitação, é fundamental que haja uma interação contínua entre todas as partes envolvidas. Por meio da interação, os objetivos vêm à tona e são legitimados através de constantes modificações. O sistema não pode ser projetado da maneira usual, mas evolui a partir das interaçôes sociais. $O$ mecanismo de prototipagem ou da aprendizagem evolutiva a partir da interação, com suas implementações parciais, é a forma pela qual a tecnologia é assimilada pela percepção social e pelo processo de criação de sentido.

A perspectiva da pessoa-que-desenvolve-como-facilitador apoia-se na complexidade da realidade que é, por natureza, confusa. Não existe a tentativa de dissimular esta complexidade pretedendo que exista uma ordem subjacente que pode ser capturada em modelos simplificadores. A realidade é construída socialmente e é produto da interação social contínua. Oenvol vimento sugeridopela interação social produz um conhecimento experimental mútuo, cuja singularidade e idiossincrasia - reveladas em cada situação especifica - impedem que a realidade seja tratada apenas através de princípios e leis universais. Existe, assim, um desvio do rigoroso paradigma cientffico da predição por leis explicativas que se transforma em avaliação interpretativa da experiência. Nesta posição, o conceito de racionalidade não possui nenhum papel significativo.

A ênfase dada é a de duvidar da eficácia de métodose ferramentas objetivose rigorosos, enfatizando-se a complexidade do desenvol vimento de sistemas. Esta perspectiva propðe uma abordagem para o desenvolvimento de sistemas que facilite o aprendizado de todas as pessoas envolvidas. Isto implica em uma virada no papel de quem desenvolve, de um especialista em sistemas para um facilitador que auxilia a estimular reflexão, cooperação e aprendizado experimental. Na prática, a abordagem do relati vismo social busca fornecer ferramentas específicas que o facilitador possa usar para dar suporte às interações da equipe de projeto. Exemplos destas ferramentas são a manutenção de diários, váriostipos de mapeamentos (históricos, de diagnósticos, ecologicos, e virtuais), grupos especiais pedagogicos, uso de metáforas para estimular mudanças mentais. Estas ferramentas podem ser usadas pelas pessoas envolvidas para explorar, aprender, aumentar a consciência, inventar soluções para problemas, e definir ações. Tudo isto é acompanhado por uma crença de que o resultado do desenvol vimento do sistema não é tão importante, mas sim a forma pela qual ele é alcançado. Por esta razão, a abordagem 
Principais envolvidos

Narrativa

Roteiro

Pressuposiçסes
Proprietário e trabalhador, adminstrador e pessoa que desenvolve.

Os sistemas de informaçao såo desenvolvidos para dar suporte ao controle administrativo, refletindo o desejo de apoiar os interesses dos proprietários as custas dos interesses dos trabalhadores.

Buscar o ideal de uma evolução da escravidåo otravés da economia feudal e do capitalismo de mercado para uma economia planejada e administrada coletivamente.

Epistemológica. É a do positivismo na forma especifica de uma visð̊o materialista da história e da sociedade:

Ontológica. É a do realismo, refletindo a crença na pré-existéncia de uma realidade empirica. favorece intrinsecamente uma forte participação. $O$ tipo de sistemas produzido por esta abordagem estimula a criatividade e a construção de sentido. $O$ uso da criatividade não é visto como um meio para se alcançar qualquer objetivo específico ou benefício.

Esta perspectiva sugere que tudo é relativo: a aceitação do sistema é a única coisa que importa. A interação social é fundamental para a aceitação mas não existe nenhuma forma de distingüir entre um consenso válido e um falacioso (inautêntico, manipulativo) [86]. Por causa de seu instanciamento relativo, a abordagem parece completamente acrítica em relação às potenciais disfunçð̃es geradas pelo uso de particulares técnicas e ferramentas para a construção de SIs. Diferentes produtos gerados pelo desenvolvimento de sistemas são vistos simplesmente como resultado de diferentes realidades construídas socialmente.

Perspectiva estruturalista radical. A terceira abordagem também é uma reação recente ao mecanicismo ([27] e [196]). Ela se diferencia da segunda por postular que existe um conflito social fundamental que é endêmico na sociedade; mas ela concorda com a primeira no que se refere a existência de uma realidade econômica objetiva. $O$ conflito sugerido existe entre os interesses daqueles que possuem os meios de produção e o trabalho. A realidade económica é explicada em termos do conflito criado por uma condição objetiva de posse privada e se argumenta que a invenção das leis economicas éuma arma usada pelos proprietários dos meios de produção para fazer com que a classe trabalhadora acredite que não existe uma alternativa para modificar as condições em que trabalham (veja Quadro 2.4).

Nesta abordagem, quem desenvolve se depara com a necessidade de fazer uma escolha: ou se coloca ao lado da gerência/administração - e, portanto, dos proprietários - e se transforma em seu agente, ou se junta aos interesses dos trabalhadores ${ }^{2}$. No primeiro caso, o sistema irá apenas racionalizar os interesses da administração e dos proprietários. Quem desenvolve direcionará a racionalização do sistema contra os interesses dos trabalhadores simplesmente modificando a intensidade do trabalho (por exemplo, supervisão do trabalho), modificando os instrumentos de trabalho (por exemplo, substituição das máquinas de escrever por computadores), ou substituindo os objetos de trabalho (por exemplo, substituição de partes mecânicas por circuitos impressos). Em todos estes exemplos, os interesses dos trabalhadores são prejudicados por causa da perda de empregos, diminuição da dependência administrativa com relação ao trabalho, desabilitação para o trabalho em função do aumento da especialização ou padronização, e assim por diante.

No entanto, quem desenvolve pode escolher o lado dos trabalhadores, criando um sistema que atenda a seus interesses. Neste caso, os trabalhadores poderiam usar a tecnologia para aprimorar suashabilidades profissionais, tentando fazer com que o trabalho

\section{Quadro 2.4}

Elementos que compoem o arquétipo estruturalista radical.

2. Veja, sobre arelaçdo entreo conceito de interesse $\theta$ conhe cimento. (85-86), $\theta$ (133). 
tanto seja mais recompensador - economica e psicologicamente-, quanto tenha como resultado um melhor produto. Também existem ganhos em termos de produtividade, mas estes devem reverter em beneficios para o trabalhador: semana de trabalho mais curta, maior tempo gasto planejando e organizando a parte criativa do trabalho, tempo para educação continuada, maior autonomia e melhores salários. A tecnologia também pode auxiliar os trabalhadores a administrarem eles mesmos a linha de produção desta forma, os interesses de quem administra e os daqueles que trabalham acabam por coincidir. Dois exemplos de projetos que foram desenvolvidos a partir desta abordagem, na Escandinávia, são DEMOs e uTOPıA [65]: o design do sistema foi colocado nas mãos dos trabalhadores.

Aperspectiva da pessoa-que-desenvolve-como-partidária-do-trabalhadoracredita que um SI irá intervir no conflito de classes buscando prestígio, poder e recursos. 0 conflito é visto como endêmico, geralmente segue um padrão previsível que pode ser diferenciado pela análise dos interesses e estruturas sociais e as relaçóes que a elas dão suporte. Como esta abordagem relaciona todo o conhecimento aos interesses humanos, uma ciência neutra é vista como impossível de existir. Cultura, conhecimento e interesses humanos estão profundamente relacionados. As normas e valores culturais se revelam muito sutis, mas não são mecanismos efetivos de controle.

Como conseqüência, a resisténcia dos usuários à mudança é vista como algo positivo, porque é um sinal de que o trabalhador se tornou consciente de seus interesses coletivos, o que, por sua vez, é um pré-requisito para o progresso social. A abordagem sugere que quem desenvolve deve buscar uma situação de estreita colaboração com os trabalhadores e/ou seus representantes: ela advoga uma visão participativa do desenvolvimento de sistemas, mas com apenas um lado - o do trabalho. A idéia é que isto leva ao fortalecimento das condiçōes de trabalho, e a uma melhor qualidade do produto. Aqui a racionalidade s 6 é válida se estiver associada aos interesses dos trabalhadores.

$O$ problema desta abordagem é que ela pode levar a algumas consequiências disfuncionais graves. Ela abraça uma espécie de ativismo - onde é mais importante mudar o mundo do que interpretá-lo ou conhecê-lo - que reduz a possibilidade de um consenso justificado quando se procura cooperação e se encontra apenas conflito. Ela também parece acrítica com relação aos efeitos de diferenciação social gerados pela organização dosinteresses de classe em sindicatos ou outras formas deorganizaçãodos trabalhadores (por exemplo, partidos polfticos). Estes efeitos incluem a manipulação dos constituintes pelos líderes destes grupos, e a "cooptação" e o relativo isolamento destes líderes que, muitas vezes vivem em esferas sociais diferentes das de seus companheiros.

Mais do que isso, esta abordagem parece ter uma tendencia de super-simplificação: por exemplo, existem apenas dois lados em disputa, não existem conflitos entre trabalhadores eseus representantes, existe uma classe homogênea administração/proprietários, etc. Ela acredita também que a falta de conflito é indesejável já que reforça o status quo. Ela assume que existem leis imutáveis análogas as naturais que determinam o futuro da sociedade. Isto leva à chamada falácia do historicismo, onde todos os eventos são vistos em termos de um conflito inevitável.

Perspectiva neohumanista. A última perspectiva é uma reação às outras três. Enquanto as outras podem ser observadas em sistemas existentes, esta perspectiva é hipotética na medida em que foi construída a partir da teoria [134-136]. A idéia é a de que, através do desenvolvimento de SIs, a vida organizacional é modificada, mas a racionalidade desta 
Princlpais envolvidos

Narrativa

Roteiro

Pressuposiçoes
Investidores (fornecedores, trabalhadores, administradores e proprietários) e pessoa que desenvolve.

Os sistemas de informaçåo so̊o desenvolvidos para remover infiuéncias deturpativas e outras barreiras ao discurso racional; seu desenvoivimento é governado por três Interesses em conhecimento: técnlco, compreensão mútua e emancipaçð̃o.

Busca do ideal de emancipaçåo.

Epistemológica. É composta por dols tipos: positivismo para os interesses em conhecimento relacionados com controle técnico, e anti-positivismo para os interesses relacionados com compreensóo mútua e emancipação; Ontológica. Também é composta por dois tipos: realismo para os interesses técnicos e nominalismo ou construtivismo social para os interesses em compreensర̊o mútua e emancipaçర̋o. mudança é fortemente restringida pelas influências sociais, que canalizam os valores, normas e percepçðes de todos os participantes. Através de várias formas de comunicação, os significados partilhados evoluem para uma cultura complexa que não pode ser reduzida a um conflito bipolar entre duas ideologias (veja o Quadro 2.5). Existem, isto sim, duas arenas onde ocorre a ação humana. Uma é o domínio do trabalho, de onde as pessoas extraem os recursos para a sua sobrevivência. A segunda está conectada ao meio de uso da linguagem com o proposito de estabelecer uma compreensão mútua e se engajar em um discurso emancipatório. Os conceitos de trabalho, compreensão mútua e emancipação formam os três domínios fundamentais ao redor dos quais a sociedade e outras formas de organização social se agrupam. Eles também formam os domínios sobre os quais se exige a aquisição de conhecimentos, e cada domínio está relacionado a diferentes tipos de conhecimento. Habermas denomina estes tipos de "interesses em conhecimento"3.

O trabalho é o primeiro domínio e está relacionado com o interesse por controle técnico dos objetos e forças naturais (clima, gravidade, temperatura, etc.), e pessoas (como para coordenar as atividades de uma força de trabalho). É umacaracterística única do ser humano procurar conhecimento para melhor exercitar o controle sobre a natureza e pessoas e, assim, racionalizar o trabalho. Para Habermas, "o objetivo é o de sobrepujar os obstáculos sociais e naturais obtendo produtos e serviços para a manutenção e reprodução da espécie humana" [85]. O principal veículo para esta realização é através das ciências exatas, que podem ser caracterizadas pelo domínio do instrumental para o raciocínio, ou pela adoção do positivismo como base para checar a validade do conhecimento que obtém. Os sistemas de informação são uma importante fonte para se obter este controle. A abordagem funcionalista sugere como isto pode ser feito. No entanto, os SIs têm um papel muito importante na realização de dois outros interesses em conhecimento: a compreensão mútua e a emancipação.

$O$ interesse em conhecimento sobre compreensão mútua tem como objetivo melhorar a compreensão da cultura e da psiquê de cada um, e da psiquê daqueles com os quais as pessoas interagem (istoé, parentes, amigos, inimigos). Colocando-se quase do ponto de vista oposto às ciências exatas - que servem basicamente ao interesse técnico - as ciências culturais (história, filosofia, literatura, psicanálise, antropologia, etc.) dão apoio ao interesse em compreensão mútua. Como no mundo social a compreensão mútua é problemática, a hermenêutica se desenvolveu para auxiliar a resolver os problemas de interpretação. A hermeneutica ${ }^{4}$ compreende o estudo dos princípios que podem ser aplicados para dar sentido a situações e textos que são diffceis de interpretar por não existirem significados estabelecidos. Um exemplo de um processo hermenêutico é a forma pela qual uma corte de justiça interpreta as leis para lidar com um novo caso de
Quadro 2.5

Elementos que compóemo arquétipo neohumanista.
3. Veja a nota anterior. 
maneira a ser consistente com decisões anteriores. Nesta abordagem, quem desenvolve se depara com uma questão hermeneutica quando interpreta os requisitos para o sistema, porque o sistema existente é como um texto estranho que precisa ser decifrado [21]. Além disso, o desenvolvimento de um sistema também cria uma questão hermenêutica na medida em que intervem nos modos de construção e comunicação de sentidos estabelecidos.

O interesse em compreensão mútua por si só não possui uma visão crítica por duas razões: (1) ele não se protege contra interpretações distorcidas; são đistorções que podem surgir em função de influências como a ideologia e os limites de uso da linguagem porque, como afirmam Winograd \& Flores [225], "nossas crenças e suposiçoes implícitas não podem ser explicitadas totalmente"; (2) ele não leva necessariamente a ações contra situaçőes injustificáveis.

Neste caso, a hermenêtica auxilia na compreensão das limitações e barreiras ao aprimoramento da qualidade da condição humana na direção de maior independência em relação às necessidades fisiologicas e à dominação social. A remoção destas barreiras pode ser encontrada através do processo histórico da emancipação. Isto leva ao terceiro interesse em conhecimento, cujo próposito é o estabelecimento da verdade e da justiça como uma forma reguladora de todas as atividades humanas - da família às organizaçōes, governos e relaçð̋es internacionais. $O$ interesse na emancipação está preocupado com uma crítica social e com a aplicação do conhecimento técnico e da compreensão mútua, visando remover todas as restrições indesejáveis à liberdade social e ao crescimento pessoal.

Possuindo o conhecimento sobre emancipação, quem desenvolve torna explícita (através da interação) a compreensão mútua dos vários obstáculos para a comunicação humana. Quem desenvolve precisa adquirir uma boa estimativa (de dentro do domínio) dos diferentes pontos de vista e situações existenciais dos diversos grupos envolvidos. Mas isto não pode ser feito por uma observação objetiva externa: é fundamental uma participação real. Obstáculos, noentanto, não faltam. Quem desenvolveprecisa considerar os seguintes obstáculos típicos à comunicação humana do começo ao fim do desenvolvimento do sistema:

- Autoridade e poder ilegf́timo;

- Pressão do grupo (“o que os outros pensam”);

- Limitaçốes de tempo, espaço e recursos no uso de conhecimento;

- Diferenciação social;

- Alcance e limitação do uso da linguagem.

Tudo isso cria dificuldades na compreensão da relevância e das implicações das questôes de design dentro dos contornos organizacional e social. $O$ objetivo da legitimação de um sistema deve emergir de uma discussão livre e aberta que leve a uma com-

4. Para uma definiçoo mals detalhada da apllcaçăo da hermenéutica na computaçoo, veja (225). preensão mútua, sem os efeitos destas barreiras.

\section{O uso de múltiplas perspectivas}

A sugestão de Kammersgaard [104] é a de tentar aplicar não apenas uma, mas várias perspectivas em todas as situações onde se estiver utilizando computadores. $O$ maior problema parece ser que, por tradição, a perspectiva de sistemas é praticamente considerada dentro de amplos círculos da comunidade de informática como a única 


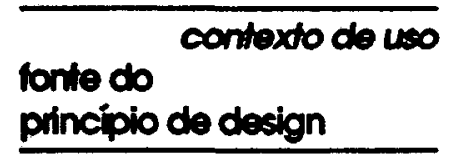

nivel de expressőo

nivel de conteúdo

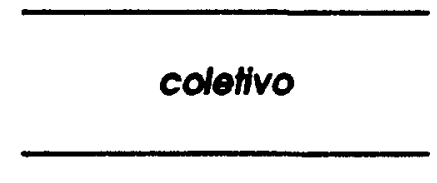

perspectiva de sistemas

perpectiva de melo

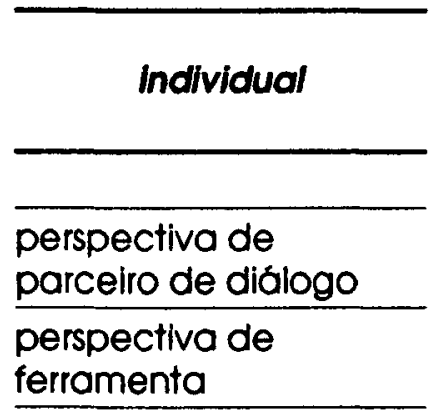

perspectiva relevante para o uso de computadores. Apesar de ser extremamente valiosa para a compreensão das relaçð̃es entre os diferentes componentes de um sistema computacional, a perspectiva de sistemas esbarra em sérias limitaçőes ao tentar compreender como os computadores são utilizados. Não ê suficiente olhar apenas a partir de uma perspectiva o uso de computadores; e a perspectiva de sistemas não é a mais adequada para fornecer tudo o que precisa quando se trata do uso de computadores. Portanto, a maneira pela qual os sistemas computacionais usualmente são desenvolvidos se torna um grande problema, já que se baseiam fortemente nesta perspectiva. Muitas das consequiencias negativas do uso de computadores por trabalhadores podem, pelo menos em certo grau, ser vistas como consequiência da falta de atenção dispensada ds outras perspectivas durante o processo de desenvolvimento.

Um grande problema quando se tenta descrever diferentes perspectivas é o de que as pessoas não conseguem evitar de ter, também, uma perspectiva para descrevê-las. $\mathrm{Pa}$ ra que esta perspectiva sobre as perspectivas fique clara, o Quadro 2.6 apresenta uma pequena taxonomia baseada em duas distinções fundamentais e as quatro perspectivas a seguir são classificadas de acordo com esta taxonomia.

A primeira distinção básica quando se fala no uso de computadores se refere a um foco no uso individual ou no uso dentro de um contexto coletivo. Quando as perspectivas de parceiro de diálogo e de ferramenta são aplicadas, existe a tendência de se olhar apenas para o uso individual, enquanto que com as perspectivas de sistemas ou de meio, a preocupação passa a ser com o uso de computadores dentro de um contexto coletivo.

A segunda distinção básica está relacionada à fonte de princípios para o design da interface com o usuário. Quando a perspectiva de ferramenta ou de meio são aplicadas, é possível enxergar o conteúdo dos processos de interação (isto e, o significado do processo de trabalho ou do processo de comunicação) como a principal fonte para os prinć́pios de design. Quando a perspectiva de sistemas ou a de parceiro de diálogo são aplicadas, a própria perspectiva parece fornecer estes princípios. Os computadores e os seres humanos são vistos como comparáveis. Vistos a partir da perspectiva de sistemas, os seres humanos são equiparados a outros componentes (automatizados) de um sistema; e, do ponto de vista do parceiro de diálogo, os computadores são vistos como se possuissem comportamento comunicativo semelhante ao humano. As duas maneiras de tratar o problema fornecem princípios para o design de interfaces que são independentes do conteúdo do processo de interação. Utilizando termos emprestados da lingüística, podese dizer que a segunda distinção busca identificar se e o nível de expressão ou o de conteúdo que é fonte primária para os princípios utilizados no design.

Conceitos básicos. Para homogeneizar os conceitos utilizados durante a apresentação de quatro das perspectivas úteis ao design de interfaces, é apresentado a seguir um conjunto básico de definiçôes que serão utilizadas quando houver referência a processos de interação. Ao utilizar a palavra interação, se faz uma associação entre processos nos quais as tarefas são desempenhadas por esforços comuns de participantes considerados como semelhantes. Mas seres humanos e máquinas não são semelhantes. $\mathrm{Na}$ falta de
Quadro 2.6

Uma taxonomia para perspectivas (cf. (104)). 
outra palavra e como esta reflete uma posição já bem definida na comunidade científica, o termo será utilizado principalmente para denotar as características dos processos que ocorrem quando os seres humanos estão usando computadores (isto é, processos de uso de computadores).

Quando lidamos com a funcionalidade de um aplicativo, lidamos com o que pode ser feito com o aplicativo, com o conjunto de possíveis produtos, e com os propósitos para os quais o aplicativo é útil para o usuário. Um aplicativoé desenvolvido para preencher certos propósitos dentro de um domínio. A funcionalidade está relacionada às tarefas executadas dentro deste domínio e é caracterizada principalmente em relação a estas tarefas; por exemplo, um processador de textos é desenvol vido para dar suporte a atividades dentro do domínio de preparação de documentos, e sua funcionalidade está relacionada principalmente com as tarefas de digitar e formatar o documento.

Ao lidar com a interface com o usuário, estão em jogo a maneira de se obter um efeito desejado, e as possibilidades de controle sobre o aplicativo. Existem diversos quadros de referência gerais com o propósito de caracterizar a interface com o usuário. Um deles é o de Foley et al. [66], que define o design conceitual, semántico, sintático e léxico da interface (veja também, a este respeito, [142]). Nesta abordagem, no entanto, utilizaremos um quadro de referências introduzido por Newman \& Sproull [168]. Estes autores vêem a interface com o usuário como consistindo de quatro componentes: o modelo de usuário, a linguagem de comando, a apresentação de informação, e o feedback.

Uma parte especifica do software pode contribuir tanto para a definição da funcionalidade quanto para a da interface com o usuário; assim, o software não pode ser dividido em partes disjuntas apenas através de conceitos. Funcionalidade e interface com o usuário apenas definem duas perspectivas diferentes de um aplicativo computacional.

Inspirado em algumas das escolas mais influentes dentro da psicologia e da ciência cognitiva, o conceito de modelo passou a ter um papel importante na área de interação homem-computador. De acordo com estas escolas, os seres humanos criam modelos mentais (veja, por exemplo, [174] e [212]) dos fenômenos com os quais lidam. Este ponto de vista levou muitos cientistas cognitivos e designers de interface a acreditarem que, baseando o design de um aplicativo em um modelo conceitual (uma explícita interpretação de aspectos qualitativos de um fenomeno), isto faria com que o usuário desenvolvesse um modelo mental similar ao modelo conceituals ${ }^{5}$.

Quando os sereshumanos interagem com computadores, vários processos ocorrem tanto na pessoa quanto no computador; mas estes processos são fundamentalmente diferentes em sua natureza.

Como uma parte inseparável das açóes do usuário, os processos de pensamento

5. O concelto de modelomental está associado ao de metáfora e a area de $\mathrm{HCl}$ tem tentado empregat diversas metaforos para facilitar o uso dos aplicatlvos. Exstem vơrlas critlcas (107), $(165-166), \theta$ posiços a favor (126) $\theta$ (174). Contudo. multas questoes alnda noo eståo resolvidas. humano participam de uma relação dialética com a pré-compreensão e o repertório da pessoa. Por um lado, pré-compreensão e repertório limitam a maneira de pensar dos seres humanos mas, por outro lado, eles surgiram como conseqüência do pensar e agir humanos. Além disso, o controleresultantedepossuir uma pré-compreensão e repertório é um pré-requisito para ser capaz de pensar e agir.

Apenas uma pequena porção desta pré-compreensão e repertório é relevante durante um particular processo de interação. Esta porção, chamada de cognições operativas daqui em diante, está sujeita a modificaçőes durante o processo de interação.

Dentro do computador, está ocorrendo a execução do programa. Através deste processo, dois tipos de importantes mudanças podem ocorrer. Os processos de interação geralmente podem levar a mudanças dentro do domínio de representação; isto $\mathrm{E}$, a re- 


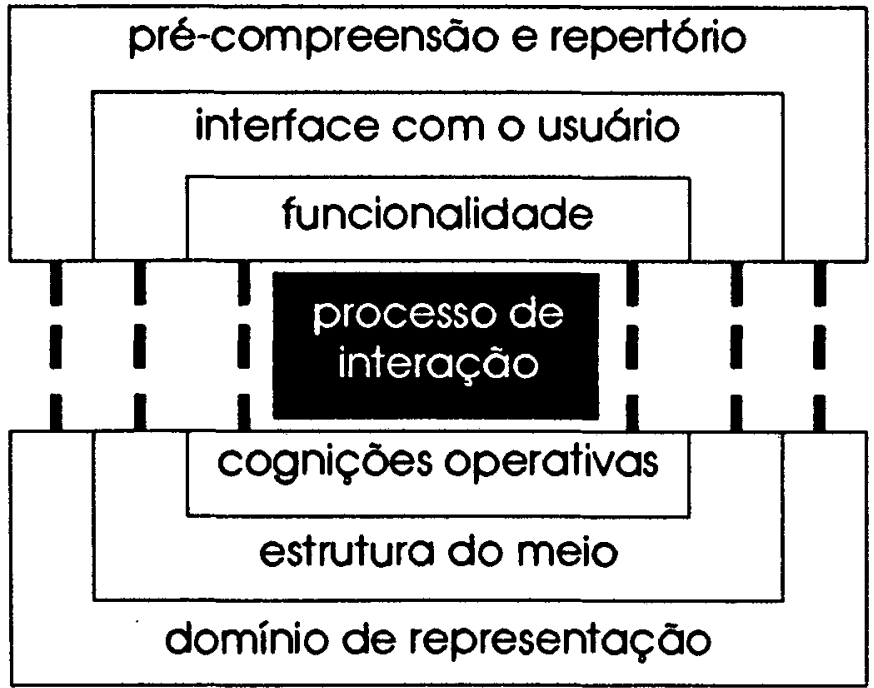

presentação dentro do computador dos fenômenos relacionados ao domínio. Além disso, a estrutura do meio (istoé, o que se pode ver no monitor, o que se pode ouvir, como utilizar os dispositivos de entrada, etc.) está sendo constantemente modificada como resultado da interação do usuário com o computador; geralmente istoocorre para modificar o domínio de representação, para apresentar diferentes aspectos deste domínio de representação de di ferentes maneiras para o usuário, ou para direcionar o usuáriodurante a interação com o computador.

Para apresentar as relaçōes entre alguns dos conceitos e a interação homem-computador, existe a relação entre um processo (por exemplo, o processo de interação) e as estruturas a elerelacionadas. Algumas estruturas devem se modificar durante oprocesso de inter ação. Entre estas estruturas interiores estão as cognições operativas, a estrutura do meio e o domínio de representação.

Outras estruturas limitam e restringem o processo de interação; elas definem os limites dentro dos quais pode ocorrer o processo de interação. Entre estas estruturas superiores estão a pré-compreensão e o repertório do usuário e a funcionalidade $\mathrm{e}$ a interface com o usuário do aplicativo. Apesar destas estruturas serem bastante estáveis, é claro que elas podem ser modificadas; por exemplo, por causa das necessidades que surgiram a partir de um ou mais processos de interação. As relações entre o processo de interação e suas estruturas estão sumarizadas na Figura 2.2.

Perspectiva de sistemas. Quando a perspectiva de sistemasé aplicada, considera-se um fenómeno como sendo formadopor diferentescomponentes que, basicamente, possuem as mesmas propriedades. Todos os componentes podem ser caracterizados por um conjunto de tipos de dados e um conjunto de açð̃es que pode envolver o próprio componente assim como outros componentes. Cada componente pode transferir dados para os outros, e cada componente pode processar dados de acordo com regras pré-definidas.

Olhando o uso de computadores a partir deste ponto de vista, a atenção está centrada no uso dentro de um contexto coletivo. Sob este foco, uma organização é uma coleção de componentes humanos e automatizados que, através de suas açóes interrelacionadas, executam determinadas tarefas. A relevância destas tarefas somente pode ser expressa ao nfvel organizacional, não ao nível individual.

Faz sentido, então, fornecer guidelines para o design de uma interface sem analisar o conteúdo do processo de interação; istoé, sem o conhecimento sobre a tarefa a ser executada pelo sistema. Todas as interações são vistas como transmissão de dados entre um ser humano e um componente automatizado, e oúnico aspecto essencial a ser levado em
Flgura 2.2

Relaçóes entre o processo de interaçóo e suas estruturas 
conta, quando a interface é criada, é o de fazer com que esta transmissão seja eficaz e eficiente; isto é, tornar possível ao usuário agir de maneira similar aos componentes automatizados.

Como já foi dito antes, a interação homem-computador, comoé vista pela perspectiva de sistemas, lida com a troca de dados entre um ser humano e um componente automatizado de um sistema. A transmissão de dados deve ocorrer em ambas as direçðes. Do ser humano para o componente automatizado a transmissão de dados ocorre principalmente para modificar o domínio de representaçðo ou para solicitar transmissð̋es em outras direções. A estrutura do meio experimenta apenas pequenas alterações, por exemplo, quando os caracteres surgem na tela ou quando erros são informados. Isto não é visto como um objetivo explícito para modificar a estrutura do meio de maneira que possa levar a mudanças dentro das cognições operativas do usuário; isto é, não se dá importância a como a estrutura do meio se modificou.

A transmissão de dados do componente automatizado para o humano pode ocorrer em modificaçōes nos documentos dentro do domínio de representação (por exemplo, para reduzir o número de erros), para guiar o usuário de maneira a aumentar a velocidade de transmissão de dados, ou para fornecer dados para uso externo ao sistema. A estrutura do meio está sendo modificada durante este processo, mas não se dá importância a como isto está ocorrendo; não existe a preocupação sobre como estes dados estão sendo apresentados ao componente humano. Os dados transmitidos ao componente humano devem servir para uso externo ao sistema, não para modificar as cognições operativas do usuário.

Quando esta perspectiva é utilizada, considera-se como qualidade essencial de uma interface com o usuário a habilidade de garantir que a transmissão de dados entre componentes humanos e automatizados ocorra de acordo com regras pré-definidas. A padronização da interface e o condicionamento do usuário são vistos como uma boa solução. Isto assegura um processo de interação padronizado com uma pequena margem para erros quando o usuário entra dados no sistema ${ }^{6}$.

Usando a terminologia de Newman \& Sproull, é possivel dizer que uma interface com o usuário, vista pela perspectiva de sistemas, deve ter uma linguagem de comando padronizada, usar o feedback principalmente para relatar erros, e usar a apresentação de informaçăo para tornar a transmissão de dados a mais eficiente possivel.

Qual e o papel dos modelos conceituais a partir do ponto de vista da perspectiva de sistemas? Pela observação do desenvolvimento de um sistema, a resposta pode ser que eles não têm papel algum. É claro que, durante a fase de desenvolvimento, são criados modelos do sistema, mas eles geralmente são expressos na forma de conceitos de processamento de informação. Estes modelos não são inúteis; podem ser muito úteis para a implementação do sistema. O problema está na falta de um modelo conceitual

6. Veja, sobre aconcepçao de "Idilot-proof systems" (sistemas aprovadeldiotas), adlscussdo sobre o design de portas em (174). ajustável ao usuário, o que deixa os usuários sem opção a não ser a de pensar e falar sobre o sistema na linguagem do processamento de informações.

A pesquisa em interação homem-computador baseada nesta perspectiva tem como principal objetivo encontrar princípios para a interaçăo que aumentem a velocidade de transmissão de dados entre componentes humanos e automatizados de um sistema e reduzam a taxa de erros.

Muitos dos chamados "experimentos em fatores humanos" tiveram, por exemplo, como objetivo encontrar a maneira mais rápida e segura de transmitir dados entre diferentes tipos de sistemas. Pesquisa deste tipo não é inútil. É necessária para que se com- 
preenda que a pesquisa quantitativa não é suficiente. Ela pode ser apenas uma pequena parte de um todo no qual os aspectos qualitativos desempenham um papel mais importante. Os aspectos qualitativos ficam visíveis se o uso de computadores for visto também a partir de outras perspectivas.

A principal vantagem de se aplicar a perspectiva de sistemas é que se torna possível obter uma visão completa de sua totalidade. Pode-se perceber os diferentes componentes e como os dados fluem entre eles. Desta forma, a analise e o design do fluxo de dados podem ser facilmente obtidos para um sistema.

Em relação à interação homem-computador, a principal desvantagem desta perspectiva é que ela não permite que se pense em interação a não ser como transmissão de dados. Outra desvantagem é a de se considerar tanto os seres humanos quanto os computadores apenas como transmissores de dados. A interface com o usuárioé considerada apenas como mais uma interface entre dois componentes. Assim, durante a fase de design é mais importante encontrar uma maneira de distribuir os dados processados entre os componentes humano e automatizado, do que enfrentar o design de uma interface com o usuário. Uma terceira desvantagem é que a organização é vista de cima, e vista como uma estrutura cujos mais importantes aspectos podem e devem ser formalmente descritos. Assim, na fase de design surge a tendência de se reduzir o trabalho humano, dentro do sistema, a procedimentos algorítmicos, porque não se pode considerar aspectos que não possam ser descritos em termos de processamento de dados. A utilização apenas desta perspectiva no design de uma aplicação para computador faz com que o sistema esteja muito mal preparado para qualquer tarefa.

Perspectiva de parceiro de diálogo. A perspectiva de uso dos computadores que tem um papel importante dentro da comunidade de Inteligência Artificial é a de parceiro de diálogo. Seres humanos e computadores são vistos como parceiros em um diálogo. 0 processo de interação é visto como um processo de comunicação no qual o usuário e o aplicativo agem os dois como emissores e receptores, e o aplicativo é considerado capaz de mostrar um comportamento comunicativo semelhante ao seu parceiro humano.

Nesta perspectiva, o foco de uso está dentro de um contexto individual. $O$ que se vê é um usuário se comunicando com um aplicativo para conseguir realizar uma tarefa. É considerado como correto estabelecer guidelines para o design da interface com o usuário sem se conhecer o conteúdo do processo de interação. A qualidade fundamental desta interface é a de ser capaz de fazer com que o aplicativo aja como um ser humano em um processo de comunicação.

Como a interação homem-computador é vista como similar à comunicação interpessoal, o processo de interaçãoétido principalmente como alterador da quantidade de informação disponível para os parceiros do diálogo. Assim, as principais mudanças ocorrem dentro do domínio de representação e das cognições operativas. A estrutura do meio atua como uma espécie de meio de comunicação entre os parceiros, de maneira que as mudanças dentro desta estrutura ocorram apenas para fornecer informaçбes aos parceiros de diálogo. As mudanças na estrutura do meio não têm nenhum papel, não importando a maneira pela qual elas são capazes de afetar outras estruturas interiores. As mudanças na estrutura do meio somente são importantes se apóiam outras mudanças, perdendo seu significado logo apos terem ocorrido. 
Ao aplicar esta perspectiva, o foco está na interface com o usuário ao invés de na funcionalidade. É a interface que deve ser criada de maneira a tornar possível a atuação do aplicativo como parceirode diálogo. Isto nãosignifica, no entanto, que os pesquisadores acreditem que ela seja aplicável a todo tipo de software independentemente de sua funcionalidade. Esta perspectiva geralmente é empregada quando se deseja desenvolver aplicativos para serem usados - em seu sentido mais amplo - com o "propósito de consulta".

Como a comunicação entre seres humanos é vista como ideal, a linguagem natural é tida como um componente muito importante da interface com o usuário. Nos termos de Newman \& Sproull, o ideal seria uma linguagem de comando o mais proxima possivel da linguagem natural, um feedback que permita a meta-comunicação sobre, por exemplo, a funcionalidade do aplicativo, o foco na conversação, etc, e uma apresentação da informação muito próxima das construções da linguagem natural.

Quando a perspectiva de parceiro de diálogoe aplicada, não se encontra nenhuma necessidade de criar modelos conceituais explícitos e específicos de um domínio. Independentemente do domínio e da funcionalidade, sempre é possível usar o mesmo modelo como base para o uso de um aplicativo; precisamente 0 modelo que assegura que 0 computador age como um ser humano em um processo de comunicação. Assim, para usar um computador são necessárias apenas habilidades comunicativas. Se alguém não está familiarizado com certos aspectos da interface com o usuário ou de sua funcionalidade, basta perguntar. Assume-se que o aplicativo é capaz de explicar tudo sobre si proprio. Da mesma forma, se alguém não compreende o que o computador "diz", basta pedir mais explicações.

A pesquisa baseada nesta perspectiva tem como principal objetivo transformar o aplicativo computacional em um bom parceiro de diálogo. Programas de pesquisa desta linha procuram resolver problemas de como tornar a comunicação com um computador robusta, como criar parsers flexiveis, como representar domínios de conhecimento dentro de um aplicativo, como devem ser projetadas facilidades para explicações, como manipular descrições de metas e objetivos, e como gerar sentenças que se adequem ao contexto da conversação.

A maior força desta perspectiva está no fato de que a pesquisa se tornou consciente de que pode aprender alguma coisa sobre como projetar interfaces com o usuário a partir da análise do comportamento comunicativo humano. Infelizmente, esta tambémé a sua maior fraqueza porque, como pode ser visto em muitas das abordagens de Inteligência Artificial para o design de interfaces, existe o risco de que esta abordagem seja usada muito além de seus limites. Parece uma verdadeira ofensa a complexidade e poder da linguagem natural quando se diz que um computador é capaz de agir como um parceiro de diálogo em processos similares a comunicação interpessoal. Aplicando apenas esta perspectiva ao projetar a interface com o usuário significa não levar isto em conta. E potenciais colapsos não tratados durante a fase de design dificilmente podem ser sanados durante a utilização do aplicativo. Assim, a perspectiva de parceiro de diálogo somente deve ser usada com propósitos muitos especializados, e apenas quando for combinada com outras perspectivas.

Perspectiva de ferramenta. Quando seolha o uso do computador a partir da perspectiva de ferramenta, o foco de atenção está no uso individual. Um aplicativo é visto como uma "caixa de ferramentas" que contém o necessário para que, com o controle completo e 
contínuo do usuário, possa transformar materiais em produtos mais refinados. Não se vê aqui nada de comparável entre as características do computador e do ser humano. Assim, não faz sentido usar analogias entre seres humanos e computadores como base para a formulação de princípios para o design de interfaces com o usuário. Pelo contrário, o usuário é visto como uma pessoa que possui as habilidades relevantes dentro do domínio e o desenvol vimento de ferramental baseado em computadores se apoia na crença de que as ferramentas serão usadas por pessoas habilidosas na criação de produtos de alta qualidade. Desta forma, os princípios para o design de interfaces devem estar baseados em detalhado conhecimento sobre o conteúdo onde ocorre o processo de interação.

A perspectiva de ferramenta é profundamente influenciada pela maneira de se desenvolver ferramentas que ocorre nos trabalhos manuais. $O$ ideal é que uma ferramenta seja desenvolvida como uma extensão do conhecimento acumulado sobre ferramentas e materiais dentro do domínio. Desta perspectiva, os processos de desenvolvimento devem ocorrer através dos esforços comuns de usuários habilidosos e experientes e de profissionais da computação. Os usuários possuem as habilidades tácitas necessárias como base para a análise e o design, mas eles também devem adquirir conhecimento sobre as possibilidades tecnológicas para serem capazes de usar a sua imaginação nesta área. Os profissionais da computação gastam muito tempo tentando adquirir conhecimento sobre o domínio para serem capazes de atuar criativamente durante o design. Ao mesmo tempo, são exigidas habilidades técnicas de alto nível porque as ferramentas que parecem simples e poderosas para o usuário, podem ser extremamente complexas tecnicamente.

Novas ferramentas não são projetadas pela análise edescrição formal das habilidades e conhecimento do usuário. De acordo com esta perspectiva, as partes essenciais das qualificações relevantes quando se utilizam ferramentas são as habilidades tácitas, que não podem e não devem ser descritas. A intenção não e a de automatizar partes do processo de trabalho, mas desenvolver ferramentas mais poderosas para serem usadas por usuários qualificados.

Deste ponto de vista, escolher uma ferramenta, usá-la, e avaliar o resultado de seu uso é uma seqüencia típica de ações repetida diversas vezes quando se usa um aplicativo. A interação com o aplicativo é o processo de aplicar uma ferramenta a algum material e avaliar o resultado. A estrutura do meio tem que refletir a forma pela qual o material foi modificado quando a ferramenta foi usada. Assim, as mudanças dentro da estrutura do meio têm um papel importante nas possibilidades que o usuário têm de avaliar o efeito das açőes realizadas e, desta forma, também para avaliar a maneira pela qual as cogniçôes operativas podem ter se alterado como resultado destas açóes. Odomínio de representação também é afetado, mas geralmente isto s 6 é importante para o processo de interação quando se reflete na estrutura do meio.

Aplicar a perspectiva de ferramenta requer que não faça sentido falar sobre materiais e ferramentas dentro do domínio. Não no sentido literal dos termos, mas pelo menos quando os termos são utilizados em um sentido mais geral. Uma qualidade essencial da interface com o usuário é que os materiais devem ser apresentados ao usuário de uma maneira direta. Assim, na terminologia de Newman \& Sproull, a apresentação de informação devese preocupar primariamente com a apresentação dos materiais, mas também em como apresentar o conjunto de ferramentas disponíveis. A linguagem de comando 
Como aplicar as ferramentas aos materiais depende muito do domínio. Para certos domínios, a manipulação direta através de dispositivos de interação análogos aos usados fora do ambiente computacional pode seguir uma tradição, mas para outros domínios pode ser que comandos textuais sejam uma solução mais natural. $O$ componente de feedback destes aplicativos muitas vezes se sobrepōem ao componente de apresentação de informação, porque a representação direta dos materiais também fornece ao usuário feedback imediato sobre suas operaçбes.

Uma compreensão teórica sobre as qualidades de uma interface com o usuário, comoé vista pela perspectiva de ferramenta, pode ser obtida através da teoria de $\mathrm{M}$. Polanyi [183]. Polanyi distingue dois pontos de consciência para o usuário de uma ferramenta: o ponto focal de consciência, definido com a interface entre a ferramenta e o material, e o ponto auxiliar de consciência, definido como a interface entre o usuário e a ferramenta. O que um usuário realmente quer é se preocupar com o que acontece quando uma ferramenta é aplicada em um material, não como a ferramenta deve ser manipulada. Assim, de acordo com Polanyi, uma boa interface com o usuário é aquela que "desaparece" durante o uso das ferramentas (isto é, uma interface com a qual o usuário não precisa lidar intelectualmente durante o uso das ferramentas). Somente quando ocorre um colapso quando ocorre uma situação inesperada onde um fenómeno passa de estar d mão (present-at-hand) para estar na mão (ready-to-hand), é que deve ser importante para o usuário ser capaz de lidar com a interface.

Nesta perspectiva os modelos conceituais têm um papel chave tanto no design quanto no uso de um aplicativo. Os modelos de usuários baseados no tradicional conceito de domínio - aprimorado pelos conceitos necessários para compreender as novas possibilidades e restrições impostas pela tecnologia da informática - são relevantes para vários propositos. Eles são úteis como uma forma de apoiar o design tanto da funcionalidade quanto da interface. Durante a aprendizagem, eles ajudam nas atividades que auxiliam na criação de competência conceitual. E durante o uso permitem que o usuário possa filtrar as distorções técnicas, isto é, lidar intelectualmente apenas com o ponto focal de consciência.

Um modelo de usuário é mais do que um modelo de aplicativo. Desde que ele esteja baseado no domínio da tarefa, desempenha um papel importante no processo de aumentar a linguagem profissional de maneira a que aspectos relacionados ao uso do aplicativo possam ser expressos por esta linguagem. É razoável dizer que o modelo de usuário é um modelo de como e para quais propositos o aplicativo pode ser usado dentro do dominio.

Uma infeliz tendencia das pesquisas sobre interface com o usuário é a que parece ter como objetivo principal tornar os aplicativos mais fáceis de aprender a usar. Isto leva a uma tendência para o desenvolvimento de aplicativos que são fáceis de aprender mas que não são poderosos o suficiente para realizar as tarefas para as quais foram projetados. Facilidade de aprendizagem ao invés de eficiência se transforma no objetivo principal destes aplicativos, tornando-os inúteis para usuários melhor qualificados. A pesquisa baseada na perspectiva de ferramenta deve se preocupar essencialmente com a funcionalidade. É claro que interfaces que facilitam a aprendizagem são um passo à frente; mas como o desenvolvimento de ferramentas poderosas precisa ser a preocupação principal, as habilidades especificas de um domínio sempre são um pré-requisito para que o aplicativo seja fácil de se aprender. Assim, ferramentas baseadas em computador nem sempre são fáceis de aprender para um usuário inexperiente. 
A principal vantagem desta perspectiva é sua visão de que as habilidades e qualificações dos futuros usuários formam o pré-requisito essencial de design. Sua principal desvantagem está na atençåo dada apenas ao uso individual. Apenas os aspectos que conectam usuário, ferramentas e materiais são levados em conta, de maneira a tornar impossível o tratamento destes aspectos a nível interpessoal ou organizacional. Portanto, a perspectiva de ferramenta não é a mais adequada como a única perspectiva a ser aplicada durante a fase de design.

Perspectiva de meio. Olhar para o uso do computador a partir da perspectiva de meio significa considerar o computador como um meio através do qual os seres humanos se comunicam uns com os outros; istoé, o computador pode ser comparado aos jornais, livros, filmes, televisão, telefones, vídeos, etc. Muitos dos aspectos centrais de, por exemplo, correios eletrônicos, sistemas de conferência, e sistemas para ensino à distância vêm a tona quando vistos a partir desta 6tica, mas também outros aplicativos onde os aspectos de meio têm um pequeno papel podem ser compreendidos a partir da perspectiva de meio.

Quando as pessoas se comunicam, é possível distingüir entre o nível de expressão e o nível de significado. Um emissor utiliza símbolos tentando exprimir um significado para um receptor. O receptor interpreta os símbolos de maneira a tentar entender o significado. O computador como um meio para a comunicação pode manipular apenas o nível de expressão, mas ao contrário de outros meios o computador pode ser usado tanto para criar relações "comuns" entre expressão e significado (por exemplo, texto, imagens, sons, etc), quanto para criar relaçôes mais complexas através da execução de um programa.

Esta perspectiva chama a atenção para o uso do computador dentro de um contexto coletivo. É necessária a existência demais de um usuário para ter sentido falar em comunicação. O nível de significado (isto é, o conteúdo do processo de comunicação) é considerado como a principal fonte de guidelines para o design da interface com o usuário. Deve-se tentar estabelecer uma rel ação entre o nivel de expressão e o nível de significado, o que fará com que o nível de expressão dê suporte a interpretações corretas.

A partir desta perspectiva, dois tipos de comunicação são interessantes. Em primeiro lugar, a comunicação entre (grupos de) usuários que ocorre através dos aplicativos. Em segundo lugar, a comunicação (de massa) de mão única do designer para o usuário, que ocorre quando um aplicativo desenvolvido por uma pessoa é usado por outras pessoas.

Do ponto de vista desta perspectiva, ocorre uma interação para se enviar e receber mensagens; isto é, para modificar as cognições operativas das pessoas envolvidas na comunicação. Para que isso ocorra, a estrutura do meio tem um papel importante porque sua situação é vista como um signo a ser interpretado pelo receptor. Odomínio de representação pode ser importante para o emissor ser capaz de formular a mensagem, mas não tem nenhum papel para o receptor a não ser que esteja refletido dentro da estrutura do meio. Se, por exemplo, uma pessoa distribui uma nota sobre algum topico para os membros de uma rede, isto e feito de maneira a modificar as cogniçoes operativas dos receptores em potencial, mas isso so ocorrerá se a estrutura do meio refletir de uma maneira razoável as idéias do emissor através de textos, imagens, fotografias, "filmes", etc. Não 
é importante para o receptor saber como o domínio de representação é afetado durante o processo de interação, e isto só é importante para o emissor se o domínio puder ser utilizado para criar um novo nivel de expressão da mensagem.

Se a interface com o usuário for vista a partir da perspectiva de meio, os componentes discutidos por Newman \& Sproull se encaixam perfeitamente. A linguagem de comando define o que está disponivel para o emissor expressar sua mensagem. A apresentação da informação define como a mensagem é mostrada ao receptor. $O$ feedback é visto como mensagens do proprio designer.

Como foi mencionado anteriormente, a visão básica é que se deve derivar guidelines mais específicas para o design de interfaces a partir da funcionalidade desejada: 0 nível de expressão deve ser projetado com base no conhecimento sobre o nível de conteúdo. Isto geralmente é aplicado tanto com relação à comunicação entre diferentes usuários do meio, quanto com o estabelecimento de conex бes para o meio (por exemplo, açס̃es similares para digitar um número no telefone), o queé considerado como uma comunicação designer-usuário.

Do ponto de vista da perspectiva de meio, o desenvolvimento de modelos conceituais é importante para que o aplicativo preencha os requisitos listados acima. A intromissão da linguagem profissional do designer no modelo conceitual criado pelo usuário é produtiva no sentido de tornar o usuário mais maleável para aprimorar seu modelo.

A maior vantagem de se aplicar esta perspectiva está no fato de que ela dirige sua atenção para os aspectos linguísticos do uso de computadores. Estes aspectos são muito importantes para diversos aplicativos, mas outros aspectos também devem ser considerados. Por exemplo, em sistemas do tipo CAD (Computer Aided Design), os aspectos relacionados com imagens e percepção espacial são mais importantes do que os aspectos lingüísticos.

No próximo capítulo serão discutidas questões relativas ao processo de design, a teoria do design, às alternativas que estão sendo discutidas, e à aplicação destas teorias no design de interfaces e sistemas. 


\section{Processos de design: tradição e mudança}

O designer grafico Herb

Lubalin mostra, neste

logotipo, qual o refinamento alcançado por nossa sociedade ao usar a escrita.

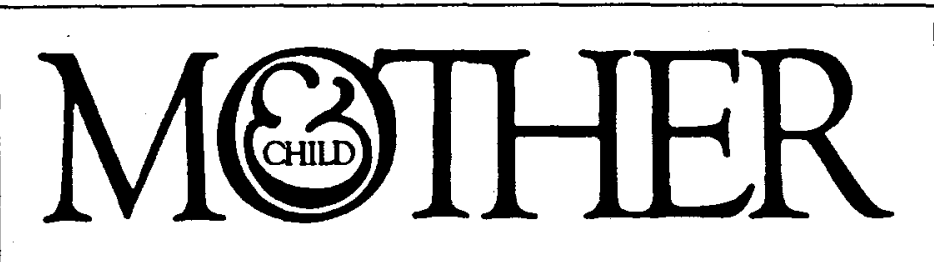


$\mathrm{P}$ or volta do século 16 surgiu nas principais línguas da Europa o termo "design" ou seu equivalente. A emergência da palavra coincidiu com a necessidade de descrever a ocupação do designer. Isto não quer dizer que a atividade de projetar era uma novidade, mas sim que ela estava se separando de outras atividades produtivas e sendo reconhecida como uma função com existência propria. Este reconhecimento pode ser visto como um marco na separação entre a mão e o cérebro, entre o trabalho manual e o trabalho intelectual. Pode ser visto também como a separação entre a parte conceitual do trabalho eo processo de trabalho. Acima detudo, o termo indica queo projetar devia ser separado do fazer.

É extremamente diffcil determinar o ponto exato de virada histórico onde esta separação ocorreu; mas este momento pode ser visto como uma tendência histórica. Até chegar a este estágio, uma grande estrutura como a de uma igreja seria "construída" por um mestre construtor. Pode-se generalizar edizer que a parte conceitual do trabalho estava integrada ao processo de trabalho. Entretanto, começavam a surgir os conceitos de "projetar a igreja" uma atividade para arquitetos e "construir a igreja" uma atividade para construtores. De maneira alguma isto sugere uma descontinuidade, mas simo início de uma perceptível tendência histórica que até hoje não encerrou sua trajetória em alguns dos principais ofícios que se valem de habilidades manuais.

Ainda existem várias profissões onde a parte conceitual está integrada à base artesanal. No entanto, a característica mais significante do estágio em questão é que, ao separar o trabalho manual do intelectual, se forneceu a base para uma posterior subdivisão do próprio campo do trabalho intelectual.

Alguns autores, como Dreyfus (citado em [46]), localizam a ráz do problema na utilização pelos gregos da lógica e da geometria, e na noção de que todo raciocínio pode ser reduzido a algum tipo de cálculo. Dreyfus afirma que Platao generalizou estes conceitos para uma necessidade epistemologica, ondepodemos dizer que todo o conhecimento pode ser especificado a partir de definições explícitas que qualquer pessoa pode aplicar.

Seo "know-how" nãopode ser especificado em termos destas instruções explícitas. então o know-how não e conhecimento, mas apenas "crença". Ele sugere que uma tradição platônica onde "cozinheiros, por exemplo, que criam por meio do paladar e da intuição, e os poetas, que trabalham a partir da inspiraçăo, não têm nenhum conhecimento. O que eles fazem não envolve compreensão e não pode ser compreendido. Mais geralmente, o que não pode ser colocado explicitamente na forma de instruçôes precisas todas as áreas do pensamento humano que exigem habilidade, intuição ou senso de tradição são relegadas a algum tipo arbitrário de busca desajeitada" [46].

Gradualmente, surgiu a visão que colocava a objetividade acima da subjetividade, o quantitativo acima do qualitativo. Nãose aceitava que ambos pudessem interagir, apesar do sistemático esforço feito para se assegurar que isto pudesse ocorrer'.

Existem aqueles que, mesmo admitindo a extraordinária capacidade de muitos dos mestres artesãos do Renascimento, tendem a acreditar que se tratava de uma forma "estática" de conhecimento com tendência a ser transferida inalterada do mestre para o aprendiz. Na realidade, nestas atividades e na transmissão de seu conhecimento estavam embutidos diversos processos para estender sua base e acrescentar novos conhecimentos, antecipando por cerca de seis séculos o ano sabático acadêmico - por exemplo, muitos dos mestres artesãos da época passaram boa parte da vida viajando pelas cidades européias onde podiam aprender com outros artesãos [46].
1. Veja. por exemplo.P. Thuillier - Techniques et Sclences: Le Message de Hugues de SaintVictor". La Recherche, 23(2). feverelro 1992, 170-179:T. Bowle - The Sketchbook of Villard de Honnecourt, Indiana, 1959: $\theta$ M. Kemp - Leonardo do Vinci: The Marvellous Works of Noture and Man.London. 1981: os dois últimos cltados em (46). 
Analisando-se os manuscritos destes mestres podemos perceber que o ofício incorporava poderosos elementos de método científico e da base conceitual ou da atividade. Podemos detectar na forma escrita destes documentos escolhida assim não por acaso os elementos básicos do que consideramos como algo científico especificamente, um processo deve apresentar as três características predominantes do que subsequentemente se transformou na metodologia cientifica ocidental, isto é, previsibilidade, possibilidade de repetir epossibilidade de quantificar. Isto, por definição, tende a excluir intuição, julgamento subjetivo e conhecimento tácito [184]. Além disso, passa-se a ver o design como algo que reduz ou elimina incertezas: "como o julgamento humano, diferentemente do cálculo, é ele próprio constituido por uma incerteza, segue a partir de algum tipo de lógica jesuítica que obom designé aquele que elimina o julgamento humano e a intuição" [46]. Mais do que isso, ao tornarmos explícitos os "segredos" do ofício, preparamos a base para um "sistema apoiado em regras". Nos dois séculos seguintes ocorreram tentativas sistemáticas de descrever e, desta forma, tornar visíveis as regras ou leis que governavam diversas habilidades manuais. Isto foi aplicado em todo o espectro de habilidades de artistas/arquitetos/engenheiros, da teoria da construção de edifícios até o pintar e o desenhar.

Este mesmo método cientffico foi aplicado a vários tipos de design. Uma interpretação destes acontecimentos é a de que este momento representa um ponto de virada na história e na metodologia do design. A partir deste momento existe uma crescente separação entre teoria e prática, uma crescente ênfase na escrita de "formas teóricas de conhecimento",e aparentemente uma grande confusão ocidental entre habilidade linguística einteligência. Ocorreu um denegrimento do que Polanyi [183] chama de "conhecimento tácito", no qual existem "coisas que sabemos mas não conseguimos explicar".

É interessante traçar as tendências de evolução do design durante os cinco séculos que separam a Renascença dos CADse sistemas especialistas da sociedade da informação. Aqui é suficiente dizer que vários pesquisadores (veja, por exemplo, [225]), baseados em uma perspectiva histórica, e levando em conta as implicações destes sistemas, concluíram que podemos estar diante de uma outra virada histórica na qual se está para repetir na área de design e outras formas de trabalho intelectual muitos dos erros cometidos em áreas onde o trabalho artesanal foi importante neste período. Estes autores sugerem que é esta a situação a que se chegou na área de design do produto.

\section{Design do produło}

$O$ design de produto tem uma história relativamente curta [152]. Até o advento da industrialização, não existia nem a iđéia de "produto" como um objeto a ser considerado isoladamente do seu contexto de uso, nem os profissionais que planejam mas não constróem estes "produtos". Antes dos objetos industrializados, os produtos eram feitos através de processos artesanais nos quais planejar e fazer eram aspectos inseparáveis de um mesmo processo. Usando de experiência prática e de técnicas de tentativa-e-erro, 0 trabalho artesanal evoluiu diretamente dentro de um contexto no qual devia se adequar aos requisitos específicos de um cliente. A experiência direta com os materiais, padrôes de uso e clientes contrasta nitidamente com o isolamento dos designers de produto com a manufatura, o uso e os usuários de seu design.

Os métodos de evolução artesanal e do design visual de produto são comparados por J. C. Jones em Design Methods[102]. De acordo com Jones, a principal diferença entre o design de produto e o processo artesanal pré-industrial é que "a técnica da tentativa- 
e-erro foi separada da produção pelo uso do desenho em escala no lugar do produto como um meio para experiências e mudanças". Ao invés de interagir diretamente com o objeto que está sendo feito, como no trabalho artesanal, a experimentação no design de produto está confinada à manipulação de desenhos em escala bidimensionais. O uso de desenhos como modelos da realidade, apesar de permitir a execução de grandes projetos que antes não eram possíveis de serem realizados por um indivíduo trabalhando sozinho e produzindo em pequena escala, muitas vezes leva a resultados que respondem de maneira insatisfatória aos requisitos individuais das pessoas. Diferentemente do mestre artesão, para o qual pensar e fazer eram partes integrais do mesmo processo, todo o design de produto desde o advento da industrialização se caracterizou por uma estrita divisão entre o pensar e o fazer.

A separação entre planejamento e execução, e o conseqüente distanciamento entre o design e o uso que é engendrado pela utilização de desenhos como ferramenta de design, levaram a dois critérios diferentes para a avaliação de design o dos designers e o dos usuários do design. Os designers utilizam critérios estáticos e visuais, resultado do uso de desenhos para avaliar um design, enquanto que as pessoas afetadas pelo design baseiam seu julgamento na satisfação de suas necessidades durante uma interação dinâmica e multisensorial. As aspirações completamente diferentes de designers e de usuários levaram a algumas anomalias bem conhecidas'.

Para Jones [103], "(...) o design industrial, nos anos 50, era uma nova profissão devotada a repensar e re-formar os designs existentes de produtos manufaturados. $O$ processo de design típico era muito conveniente para um consultor de design (que não trabalhava para uma indústria mas para várias, e tinha formação artística e não de engenharia), ao qual se fornecia um briefing [uma reunião onde a indústria apresentava os requisitos do produto para o designer] para o re-design da aparência do produto, e para repensar como ele era usado, mantendo, em diversos graus, os mecanismos interiores e a linha de produção já existentes."

A incongruência entre os modelos de realidade dos designers os desenhos e a realidade na qual o design será utilizado evidencia o problema criado pela separação entre o planejar e o fazer. As abordagens derivadas de ofícios artesanais possuem um grande número de vantagens em relação aos seus predecessores (derivados mecanicisticamente). Ao fazer, em vez de apenas planejar produtos, os designers são capazes de experimentar diretamente como seus produtos serão utilizados. A ênfase na construção de software, assim como em um ofício tradicional, deveria estar nos processos de uso do produto, sua facilidade de operação, sua adequação d tarefa e sua adaptabilidade às necessidades específicas do usuário. Em qualquer software, é a experiência do usuário, em vez do produto em si, que chama a atenção; o conceito tradicional é extendido de objetos físicos para processos intangíveis.

Ao criar sistemas que se baseiam na experiencia das pessoas ao usar seu produto, em vez de no produto em si, as pessoas que desenvolvem software criaram novos papéis para si mesmos. Assim como os artistas de vanguarda, quem desenvolve software assumiu o papel passivo de fornecer sistemas dos quais qualquer um pode participar. Diferentemente do design de produto tradicional, que está comprometido em ser apenas uma maneira de produzir objetos físicos, o design pos-industrial, como pode ser exemplificado pela construção de software, é um processo de pensamento contínuo e não-instrumental onde ocorre uma participação igualitárịa entre o construtor e o usuário [103].
2. Veja por exemplo, o problema do design de portas $\theta$ de interruptores descrito em(130). 
Para as novas tarefas do design, como a de construir software, os atuais métodos de design são completamente inaplićáveis. "O produto" apenas como uma entidade física é uma ilusão de uma era mecanicista que não pode mais ser sustentada em uma época preocupada com a informação. Por esta razão, em vez de um conceito de design simplesmente comouma maneira de produzir objetos, é necessário desenvolver uma compreensão do design como processo contŕnuo e não-instrumental, um ato criativo no qual tanto designers quanto usuários devem participar igualitariamente. $O$ papel do designer na era pós-industrial é tornar acessível o processo de design para qualquer pessoa. Para que isso possa ser realizado, o design precisa se tornar um processo socialmente orientado no qual, como os cientistas deste século perceberam, todos somos tanto espectadores quanto atores.

Como afirma Mitchell, “a disparidadeentre a ciência clássica eas novas abordagens, orientadas a processo e dependentes-do-observador, é análoga à diferença entre os métodos de design tradicionais, com base mecanicista, e os métodos que estão sendo desenvolvidos hoje em dia. No design, assim como na ciência, a abordagem do 'objeto' ou 'produto' estático deve ser abandonada em favor de novas tarefas do design orientado a processo e dependente do usuário/observador, como é o design de software" [152].

Jones destaca que:

"Quanto mais eu conheço o design de software, mais percebo a semelhança não com o design em outros campos mas com o artesanato. Tanto em um quanto no outro, odesign - se assim o podemos chamar é feito pelo criador; existem muitos acertos, ajustes e adaptações de soluções de design já existentes, e muita colaboração, com pouca chance de uma visão 'olho de peixe' como so as mesas de desenho permitem, mostrando como a coisa toda está organizada. Enquanto na evolução de um ofício mesmo em software, os resultados possuem a aparência de organismos naturais ou de designs excepcionalmente bem integrados. Mas existe uma importante diferença: cada vez mais um software é feito através da modificação de material atualizado de antigos pedaços de outros softwares, como um ediffcio sendo alterado para um novo uso, enquanto um fabricante de carroças, por exemplo, ao dar cada pequeno passo em uma gradual evolução de seu produto, modifica a forma mas não reutiliza o material. Como na evolução natural, cada alteração e feita sem uma intenção consciente, ou plano, sobre qual o tipo de artefato que poderá surgir mais tarde a partir do processo aparentemente cego de fazer correções, aqui e ali, sobre como e quando fazer uma adaptação às condições de trabalho, ou sobre como os materiais ou os processos de execução se tornaram evidentes. Mas existe um enorme respeito pela forma, como ela evoluiu tanto, incorporando a história não registrada de outra maneira de milhares de maneiras nos quais um artefato e seu contexto podem estar em harmonia. É claro que o contexto deve ficar estável, dentro de limites, por séculos, para que a evolução do ofício seja possível. Eu me pergunto se existe alguma forma, ao tentar tirar liçōes destes diferentes modos de evolução, para que os criadores de software eos usuários destes softwares mantenhamo acordo quase mágico como contexto quandoo próprio contexto está em permanente mudança"[103]. 
A dificuldade que todas as pessoas enfrentam como usuários de todas as coisas, produtos, ou o que mais for criado ou fornecido por profissð̃es diferentes das delas, é que estão presas à sua experiência de consumidores de tal forma que aceitam os produtos, e não a elas mesmas, como pontos de partida para pensar quando se pede para que definam suas necessidades. E, como profissionais da criação de software, ou de outro produto qualquer, quem desenvolve está igualmente preso a pensar no produto como central e os usuários como existentes apenas em relação ao que fornecem. "Estamos aqui para ajudar os outros: quem são os outros não faço idéia." Istoé pensar o produto, a nem sempre visivel fraqueza da vida industrial.

A visão alternativa, que pode ser encontrada em recentes discussões sobre design, é a de pensar o processo. Ver o processo não como um meio mas como um fim, um propósito por si só. Levar em conta apenas o produto como critério significa renunciar à humanidade, o que pode ser perigoso, como foi destacado no capítulo 1.

\section{A visão alternativa}

Em Work-Oriented Design of Computer Artifacts, Ehn destaca que "em certa medida, a ciência da computação e o design de sistemas não foram bem sucedidos em relacionar o conhecimento sobre design como reflexão objetiva ao conhecimento de design como habilidade prática. $O$ último tornou-se invisível. A maneira cientrfica de pensar e fazer foi vista como superior, e tornou-se norma para a atividade prática de design e para o uso de computadores. Assim, descrição formal é outro rótulo para a ciência da computação, e sistemas a epítome do design".

O fundamento desta compreensão é uma filosofia racionalista de imagens-refletidas da realidade objetiva. Sem dúvida, é uma generalização grosseira sugerir que as teorias e os métodos de design contemporâneos dos artefatos computacionais, assim como as teorias e métodos para a pesquisa na área, pertençam a uma tradição de dualismo e raciocínio racionalista - uma tradição que podemos chamar de abordagem cartesiana [58].

A posição alternativa é a de que existe muito mais conhecimento na prática do design e do uso do que pode ser descrito formalmente ou esboçado como descriçð̃es de um sistema. O conhecimento térico é visto como importante em design, mas muito mais como um complemento para a compreensão prática do que como um substituto para ela. Assim, nas reflexões objetivas sobre design e uso de computadores, devemos destacar a importância do conhecimento como prática, compreensão cotidiana e linguagem coloquial. Isto se justifica como busca de um fundamento filosófico para a teoria e os métodos de design que possam aprimorar as capacidades dos designers e usuários para desenvolver seu conhecimento prático. Devemos procurar por um conhecimento teórico sobre a compreensão cotidiana do design.

O uso do "método cientifico" geralmente classificado filosoficamente como empirismo lógico gerou novos conhecimentos para o design de sistemas de informação baseadosem computadores mais eficientes. Novas e poderosas linguagens de programação orientadas a objeto são resultado de uma perspectiva de sistemas. E muitos dos sistemas projetados hoje em dia não poderiam ter sido criados sem os métodos racionais de design de sistemas como, por exemplo, o de Yourdon [58].

Com estórias de sucesso como essa, por que a preocupação com a perspectiva de sistemas? A razão parece ser uma sensação de que, conforme foi enfatizado no capítulo anterior: 
- a perspectiva de sistemas auxiliou na produção de sistemas hierárquicos baseados em computadores com uma crescente divisão de trabalho e menos planejamento como parte do trabalho, ao invés de processos mais democráticos de design e uso;

- o design de sistemas auxiliou na redução do trabalho de muitos empregados a meros procedimentos algorítmicos, ao invés de aprimorar suas habilidades; - a objetivação e a formalização das descrições de sistemas levaram, em grande extensão, ao afastamento dos usuários dos processos de design, ao invés de dar suporte à comunicação criativa e participativa entre usuários e designers profissionais.

Para Ehn, “(...) os exemplos da perspectiva de sistemas partilham das suposiç̃es filosóficas de raciocinio racionalista como epistemologia e de que adotamos o dualismo como ontologia. Isto não é surpreendente. Estas são suposiçð̃es filosóficas que provaram funcionar muito bem, e estas idéias têm uma longa história na tradição ocidental. Os filósofos nos dirão que as raízes desta tradição remontam a Platão, e que a ciência e a tecnologia estão baseadas, em grande escala, na versão do racionalismo fornecida por René Descartes" [58].

O protótipo de um cientista cartesiano ou de um designer de sistemas é o de um observador. Ele não participa do mundo que estuda, mas vai para casa tentar encontrar a verdade sobre este mundo pela dedução dos fatos objetivos que obteve. A verdade é encontrada através da reflexão objetiva pelo uso do método de raciocínio cartesiano. Objetos simples são organizados em sistemas mais e mais complexos que expandem o conhecimento que se tem sobre o mundo.

A filosofia cartesiana é a epistemologia e ontologia de um mundo interior de experiências (a mente) e um mundo exterior de objetos: o corpo humano sendo talvez o objeto mais significante, e a linguagem a forma humana de espelhar este mundo exterior de objetos reais.

Winograd \& Flores resumiram a abordagem cartesiana para design de sistemas da seguinte maneira [225]:

- caracterizar a situação em termos de objetos identificáveis com propriedades bem definidas;

- encontrar as regras gerais que se aplicam as situações em termos destes objetos e propriedades;

- aplicar as regras logicamente à situação em questão, traçando conclusões sobre o que deve ser feito.

Esta é a suposição epistemológica do raciocínio cartesiano. Com ela vem a suposição ontológica do dualismo:

- as pessoas são habitantes de um "mundo real" feito de objetos portadores de certas propriedades. As ações humanas ocorrem neste mundo.

- existem "fatos objetivos" sobre este mundo que não dependem da interpretação (e até da presença) de qualquer pessoa.

- a percepção é um processo pelo qual os fatos sobre o mundo são (muitas vezes de maneira imprecisa) registrados nos pensamentos e sensaçôes humanos. 
- pensamentos e intenções de ação de certa maneira provocam o movimento físico (dar mundo real) dos corpos das pessoas.

Segundo este ponto de vista, o design de sistemas não é um empreendimento social e criativo, mas um processo de racionalizaçãodas tomadas de decisão. A única coisa que precisa ser feita é descrever corretamente o mundo; o resto é simplesmente lógica. Os sistemas computacionais que são projetados não são objetos como os martelos, mas máquinas logicas como as mentes humanas. $O$ dualismo cartesiano mente-corpo paradoxalmente sugere que existe um "fantasma na máquina" [225].

\section{A Invisibilidade da habilidade e da subjetividade}

Apesar de todos os méritos da abordagem cartesiana e do pensamento sistêmico, também parecem existir razões para criticar seus fundamentos filosóficos. Os problemas principais são que as habilidades práticas e a subjetividade tornam-se invisiveis justamente porque a construção social da realidade está escondida nos bastidores.

Mas, e se o dualismo cartesiano for rejeitado, isto é, e se o que as pessoas sabem sobre o mundo e uma reflexão ou imagem de espelho deste mundo exterior de objetos? $\mathrm{E}$ se, em vez disso, as pessoas assumissem que constróm socialmente o mundo?

Se as pessoas acreditarem, como Wittgenstein (citado em [58]), que: "o que vejo quando me deparo com algo pela primeira vez, não é um atributo do objeto, mas uma relação externa entre ele e os outros objetos", então não se torna necessário fazer pressuposições sobre as representações mentais individuais de um mundo cartesiano exterior independente da linguagem. Aspectos dos objetos, ao contrário de atributos, se tornam teoricamente ancorados na pressuposição construtivista. O primeiro contato ocorre como cognição e comunicação contextualizadas (situated cognition and communication) pelas quais as pessoas dão sentido ao mundo e "o trazem para a linguagem". Existe uma mudança de linguagem como descrição para linguagem como ação. $\mathrm{E}$, mais do que isso, para que o sentido que uma pessoa dá ao mundo seja aceito por outras pessoas como intersubjetivamente válido, de alguma maneira este sentido deve refletir uma questão de controle social e negociação.

Mas o que acontece com a invisibilidade das habilidades tácitas na abordagem cartesiana? Quais as consequiências de uma dada prioridade para o pensamento racionalista refl exivo com propósitos? Apesar de tudo, como o filósofo Peter Winch (citado em [58]) coloca, "um cozinheiro não éum homem que primeiro tem uma visão de uma torta e então tenta fazé-la, ele é um homem habilidoso na cozinha, e tanto seus projetos quanto suas descobertas surgem a partir desta habilidade". Quando o cozinheiro reflete-emação, "ele não separa meios efins, mas os define interativamente conforme enfrenta uma situação problemática. Ele não separa pensar do fazer, descobrindo o seu caminho para uma decisão que mais tarde pode ser convertida em ação. Como sua experimentação é um tipo de ação, a implementação já está em sua pesquisa" [58].

Contudo, a visão cartesiana do cozinheiroe similar ao pressuposto racionalista de um designer profissional como uma pessoa que faz planos explícitos e detalhados com antecedência de todos os passos futuros, e de um usuário como alguém cuja habilidade pode ser reduzida a, e descrita por, procedimentos algoritmicos.

O que seria do melhor matemático cartesiano sem a habilidade prática de fazer alguma coisa? Será que é possível dar sentido a uma fórmula lógica, a uma expressão de conhecimento objetivo (isto é, algo codificado em uma linguagem escrita) sem ter 
aprendido uma forma socialmente partilhada de fazer marcas especiais sobre papel, e compreender como usá-las ao inferir conclusões a partir de um conjunto de premissas? Será que o raciocínio racionalista perde todo o significado, sem estas habilidades práticas que as pessoas incorporam quando são socializadas em uma determinada cultura?

Se este é o caso, será que não é hora de uma filosofia do design que não reduza, como a abordagem cartesiana faz, as habilidades práticas dos designers e dos usuários ao que pode ser formalmente descrito e compreendido pelo raciocínio racionalístico? Se esta posição for assumida, ela estará baseada, então, na pressuposição de que a habilidade prática é mais fundamental, para o conhecimento sobre design, do que o pensamento teórico racionalístico.

Ao rejeitar o dualismo cartesiano, as relações entre objetividade e subjetividade também precisam ser repensadas. Em vez de, em nome da objetividade, considerar invisíveis os aspectos subjetivos e emocionais do design e da ciência, por que não participar da prática do assunto em questão e, desta forma, construir a realidade tão objetivamente quanto for possível?

Para tanto, as pessoas podem se apoiar na suposição de que a subjetividade é uma valiosa fonte no design e na pesquisa sobre design, e não apenas um fator que necessariamente deve ser posto sob controle ou reduzido a um mínimo. Em qualquer circunstância a subjetividade deve se tornar visível. $O$ que impede a utilização desta suposição é a existência de uma tradição afeita ao dualismo cartesiano.

\section{Design para o próximo século}

O computador encontrou seu lugar nas casas, nas escolas, no trabalho e no lazer. As pessoas têm de lidar com uma torrente de novos dispositivos, se deparando tanto com benefícios quanto com perigos. Para evitar problemas, se fazem necessárias imagens que possam auxiliar na antecipação do impacto dos computadores e dirigir futuros desenvolvimentos. Os computadores são meras máquinas gigantes de calcular ou são cérebros eletrônicos? Eles podem executar apenas simples tarefas programadas ou podese esperar que aprendam e sejam criativos?

Se for enfatizada a imagem do computador como cérebro, pode ocorrer um afastamento de importantes questões. A preocupação de dar aos computadores uma inteligência como a humana (ou como a divina) se apoia em um discurso mais fundamental sobre a natureza da tecnologia e sobre o pensamento, a linguagem e o ser humano. Este discurso desdobra-se dentro de uma tradição a mecanicista, que está profundamente enraizada na moderna sociedade tecnológica.

Ao se examinar esta tradição, percebe-se que, apesar de fornecer um fértil plano de fundo para o desenvolvimento de novas tecnologias, não auxilia na adequada compreensão do que os computadores fazem no contexto da prática humana. É possível chegar a uma crítica abrangente sobre o que foi dito dos computadores e ao que está sendo pesquisado em disciplinas como a lingüística, a psicologia e a administração.

Para compreender os fenômenos que cercam uma nova tecnologia, é necessário discutir a questão do design a interação entre compreensão e criação [225]. Ao falar de design, não basta restringir o discurso a uma preocupação com a metodologia do design consciente. Deve-se encaminhar a questão mais ampla de como a sociedade engendra invençôes cuja existência, por sua vez, altera esta mesma sociedade. É precisoestabelecer uma base teórica para olhar para o que fazem os dispositivos, não apenas para como operam. 
Para desenvolver esta base teorica, é preciso examinar a compreensão implícita do design que guia o desenvol vimento tecnológico dentro da tradição de pensamento exis-tente. Somente revelando esta tradição e tornando explícitas suas pressuposições, podem ser abertas alternativas para os pesquisadores e para as novas possibilidades de design que fluem destas alternativas.

Este tipo de questionamento pode ser ilustrado a partir da pergunta "O que é uma máquina para processar textos?". A primeira coisa a reconhecer é que diferentes respostas surgirão a partir das preocupaçōes de diferentes indivíduos. Para o gerente de uma fábrica, eles são montagens de dispositivos eletrónicos e mecânicos que devem ser construidos, testados e empacotados. Para a pessoa que desenvolve o processador de textos, ele é uma coleção de software que lida com a entrada, armazenamento e saída de bytes de informação. Ele opera através de algum tipo de interface com o usuário que, por sua vez, gera e modifica a informação.

Ambas as respostas são perfeitamente válidas, surgidas em domínios particulares nos quais as teorias da computação e eletrônica são relevantes. Para compreender uma avaria de hardware ou software, se opera nos termos deste domínios que, por sua vez, são utilizados para predições. Mas estas respostas não fazem referência ao que o processador $f a z$ ao fato de que é um meio para a criação e modificação de estruturas lingüísticas que têm um papel na comunicação humana. Para o comprador de um processador de textos, este é o domínio relevante. O processador existe como uma coleção de hardware e software apenas quando há uma avaria. Durante sua operação, o usuário está preocupado com as ações de criar e modificar documentos e produzir apresentações físicas destes documentos na tela ou no papel. Odomínio relevante nãoéo computacional, mas o que surgiu há muito tempo com os primeiros instrumentos de escrita. $O$ domínio traz consigo preocupaçðes com os aspectos visuais do documento questões de layout, famnlias de letras e integração de texto e ilustraçōes. Muitos dos atuais produtos para computadores estão sendo criados com uma preocupação primária voltada para este domínio. Eles lidam com formatos e tipografia, enfatizando o documento como algo a ser produzido.

Mas, ainda assim, a compreensão do processador de textos não está completa. Não se pode tomar a atividade de escrever como sendo um fenómeno independente. Escrever é um instrumento uma ferramenta utilizada nas interações com outras pessoas. 0 computador, assim como qualquer outro meio, precisa ser compreendido no contexto da comunicação e da enorme rede de equipamento e práticas no qual está situado. Uma pessoa que utiliza um processador de textos não está apenas criando um documento, mas escrevendo uma carta, um memorando ou um livro. Existe uma complexa rede social na qual estas atividades fazem sentido. A rede inclui instituiçðes (como os correiose as editoras), equipamento (incluindo processadores de textos e redes de computadores, e também todas as antigas tecnologias com as quais eles coexistem), práticas (como comprar livros e ler jornais), e convençðes (como o status legal de documentos escritos).

$O$ alcance de uma nova invenção reside em como ela se adequa e modifica esta rede. Muitas inovações são secundárias elas simplesmente aprimoram algum aspecto da rede sem alterar sua estrutura. A transmissão automática tornou os automóveis mais fáceis de dirigir, mas não mudou sua função. Outras invençð̃es, como o computador, são inovações radicais que não podem ser compreendidas em termos da rede social já existente. A imprensa escrita, o automóvel e a televisão são exemplos de inovaçães radi- 
cais que abriram toda uma nova gama de possibilidades para a rede de relações humanas. Assim como o automóvel causou impactos na sociedade que vão muito além do que simplesmente aumentar a velocidade de tudo que antes era feito com cavalos, o uso de computadores levará a modificações que irão muito além daquelas criadas por uma extravagante máquina de escrever. A natureza das editoras, a estrutura da comunicação dentro das empresas e a organização social do conhecimento serão alterados, assim como foram quando da emergencia de outras tecnologias para a linguagem, como a imprensa escrita.

Pode-se pensar que este questionamento poderia parar neste ponto. É claro (e amplamente reconhecido) que não se pode compreender uma tecnologia sem possuir uma compreensão funcional de como ela é utilizada. Além disso, esta compreensão precisa incorporar uma visão mais abrangente da rede de tecnologias e atividades a qual ela se adequa, ao invés de tratar os dispositivos tecnológicos isoladamente. Mas isto não e o suficiente. Pode-se dizer que o processador de textos precisa ser entendido através do papel que desempenha na comunicação, na distribuição de informação e no acúmulo de conhecimento. Ao se tomar esta posição, está se aceitando como certo o significado de palavras como "comunicação", "informação"e "conhecimento", as quais por si mesmas exigem uma atenção mais cuidadosa. Em um exame mais atencioso poderia-se indagar sobre os fenômenos humanos básicos que têm dado nome a termos como "inteligência", "linguagem" e "racionalidade".

Assim como o uso de uma nova tecnologia modifica as práticas humanas, a maneira de se falar sobre a tecnologia modifica a linguagem e a compreensão desta tecnologia. Esta nova maneira de falar, por sua vez, gera modificaç̃̃es no mundo que foi (socialmente) construído. Como exemplo de um novolinguajar que cria novas possibilidades de ação, considere a introdução feita por Freud de termos como "ego", "subconsciente" e "repressão". Deum lado, pode-se dizer que foram reconhecidos e nomeados fenômenos já existentes. Mas, por outro lado, a inovação deste linguajar teve maior impacto na sociedade humana, tanto na maneira de tratar desviantes (como os prisioneiros e os lou$\cos )$, quanto na forma de ensinar as crianças.

Olhando-se para os computadores podem ser encontrados os mesmos processos. O desenvolvimento da tecnologia levou a novos usos de termos como "informação", "entrada", "saída", "linguagem" e "comunicação", enquanto o trabalho em áreas como a Inteligência Artificial trouxe novos significados às palavras "inteligência", "decisð̃o" e "conhecimento". O jargão técnico dá forma ao senso comum de uma maneira que modifica a vida cotidiana.

Para que os efeitos do uso dos computadores na sociedade sejam evidentes, é preciso revelar a compreensão implícita da linguagem, do pensamento e do trabalho humanos que servem como pano de fundo para desenvolvimentos da tecnologia do computador. Nesta empreitada, é necessário estar duplamente preocupado com a linguagem. Primeiro, ao se estudar uma tecnologia que opera em um domínio da linguagem: o computador é um dispositivo para criar, manipular e transmitir objetos simbólicos (portanto, lingüísticos). Segundo, ao se olhar para o impacto do computador, volta-se a questôes sobre linguagem: como a prática modela nossa linguagem e esta, por sua vez, gera o espaço de possibilidades de ação. 


\section{O papel da tradição}

Não é possível abordar questð̃es como essas a partir de um ponto de vista neutro ou objetivo. Todo questionamento nasce a partir de uma tradição, uma pré-compreensão que abre o espaço de respostas possíveis. A palavra "tradição" está sendo utilizada aqui em sentido amplo, sem a conotação de que pertença a um grupo social ou cultural coesivo, ou que contenha práticas ou costumes particulares. É um fenômeno mais fundamental que pode ser chamado de uma maneira de ver e que pode ser equiparado ao conceito de perspectiva adotado no capítulo 2 . Ao tentar compreender uma tradição, a primeira coisa da qual deve-se estar consciente é de como ela está disfarçada pelo óbvio.

Não é um conjunto de regras ou ditos, ou algo que pode ser encontrado catalogado em uma enciclopédia. Éuma maneira de compreender, um pano de fundo, dentro do qual as pessoas agem e interpretam suas ações. A palavra tradição é utilizada porque enfatiza a historicidade da maneira de pensar das pessoas o fato de que as pessoas so existem dentro de uma pré-compreensão determinada pela história de suas interações com outras pessoas que possuem a mesma tradição.

Ao se examinar como as pessoas têm pensado e falado sobre computadores, tornase evidente o efeito pervasivo de uma poderosa tradição que enfatiza informação, representação e tomada de decisão. Esta tradição tem servido de base para o progresso tecnológico e, ao mesmo tempo, levou a muitos dos problemas criados pelo uso dos computadores. Mesmo nas dicussões sobre o qué os computadores podem ou não fazer, as questões que são colocadas refletem uma cegueira sobre a natureza do pensamento e da linguagem humanos uma cegueira que pode levar a uma interpretação errônea do papel que os computadores terão.

Para evitar esta situação, deve-se estudar as questões referentes ao uso da linguagem (veja [134]). A tradição racionalista atribui à linguagem um sistema de símbolos que são compostos por padrões que, por sua vez, representam coisas no mundo. Sentenças podem representar coisas do mundo de maneira verdadeira ou falsa, coerente ou incoerentemente, mas sua base principal é a correspondência, que pode ser sumarizada como sendo:

- Sentenças dizem coisas sobre o mundo, e podem ser verdadeiras ou falsas.

- O que uma sentença diz sobre o mundo é função das palavras que contém e das estruturas através das quais as palavras foram combinadas.

- As palavras que fazem parte de uma frase (tais como sujeitos, verbos e adjetivos) podem ser consideradas como denotações (no mundo) de objetos, propriedades, relaçōes, e conjuntos deste tipo.

De uma maneira quase simplista, a visão racionalista aceita a existência de uma realidade objetiva feita de coisas adornadas com propriedades e imersas em relações. Um ser cognitivo recolhe informações sobre estas coisas e constrói um modelo mental ${ }^{3}$ que, em alguns casos, estará correto (uma representação da realidade baseada na fé) e em outros aspectos estará incorreto. $O$ conhecimento é um depósito de representaçóes, que podem ser chamadas pelo raciocínio quando necessárias e então traduzidas para uma linguagem. Pensar é uma manipulação de representaçð̃es.

A questão do conhecimento e da representação é central para o design de dispositivos baseados em computadores que queiram servir de ferramentas para a ampliação do conhecimento. É preciso descobrir formas de manipular conhecimento no mesmo
3. Para uma outra abordagem. veja (153) $\Theta(155)$. 
sentido que um processador de texto nos permite manipular texto. É preciso tentar construir sistemas que apliquem o conhecimento para alcançar alguma meta. Nesta tentativa, as escolhas de problemas e soluçôes serão fortemente afetadas pela compreensão do que é o conhecimento e como ele pode ser utilizado.

A linguagem é uma forma de ação social direcionada para a criação de uma orientação mútua. Esta orientação não pode se apoiar em uma correspondência entre a linguagem e o mundo, mas deve existir como um domínio de consenso como padrðes interligados de atividade. A passagem de linguagem como descrição para linguagem como ação é a base da teoria dos atos da fala, que dá ênfase ao ato da linguagem ao invés de apenas ao seu papel representacional. Particularmente, estes atos da fala geram compromisso. E, ao se revelarem como base da linguagem, podem ser situados em uma estrutura social e não na atividade mental dos indivíduos.

Ser humano significa gerar compromissos através do falar e do ouvir. Isto significa que se pode reconhecer nos computadores as ferramentas básicas para a atividade humana [32-33]. Sua força como ferramentas para a ação lingüística pode ser derivada da habilidade dos computadores de manipularem os pedaços formais do tipo que constituem os elementos estruturais da linguagem. Mas eles são incapazes de se comprometerem e, portanto, participarem de relações que envolvam linguagem.

Conhecimento e compreensão não são resultado de operações formais sobre representações mentais de um mundo objetivo existente. Conhecimento e compreensão surgem da participação individual comprometida em padrões mútuos de comportamento que estão embutidos em um repertório compartilhado de preocupações, ações e crenças.

Nesta visão, a linguagem não é mais apenas um meio para a reflexão, mas sim um meio constitutivo [185]. Os seres humanos criam e dão significado ao mundo em que vivem e que compartilham com outras pessoas. De uma maneira radical, projetam a si mesmos (e as redes sociais e tecnológicas nas quais a vida têm sentido) através da linguagem [1].

Do ponto de vista de Ehn, "prática significa a atividade prática cotidiana. A prática está associada d̀ ontologia. É a forma humana de vida. Estar-no-mundo é mais fundamental do que as relações entre sujeito e objeto. Durante esta prática produzimos o mundo, tanto o mundo dos objetos quanto nosso conhecimento sobre este mundo. A prática é tanto ação quanto reflexão. Mas a prática também é uma atividade social. Como tal, ela é produzida cooperativamente com outros seres-que-estão-no-mundo. Partilhar uma prática também significa partilhar uma compreensão do mundo com os outros. No entanto, esta produção do mundo e de nossa compreensão dele ocorre em um mundo que já existe. Assim, como parte da prática, o conhecimento deve ser entendido socialmente através da produção ou reprodução de processos e estruturas sociais, assim como ser um produto deles" [58].

As principais questões relacionadas ao uso dos computadores pela sociedade passaram da "Era do Hardware" (1965-1975) para a "Era do Software" (1975-1985) e chegaram a "Era do Homem" [152]. Isto significa que as exigências dos usuários irão se impor como ditadoras das capacidades de um programa: "nós temos a tecnologia". Desta forma, as empresas estão concentrando suas atenções na introdução do estilo de vida do consumidor no produto tornando a tecnologia mais "inteligente" e mais flexível para usuários com diferentes backgrounds culturais e no conhecimento dos contextos sociais de seus produtos. 


\section{Colaboração e comunicação}

Os problemas de uma interface geralmente são obvios. As soluçð̃es nem tanto. Pode ser difícil encontrar uma solução que resolva um problema particular sem criar novos problemas. Mesmo assim, uma soluçãoem separado para cada problema pode levar a uma interface com tal complexidade que ela não seria utilizável. $O$ que se precisa, na verdade, é de uma solução queresolva elegantemente uma ampla gama de problemas. Este tipo de solução é excepcionalmente diffcil de ser encontrada [60].

A dificuldade no design de uma interface tem como origem o fato de que praticamente todas as soluções surgem a partir de compromissos. Elas são formadas por uma multiplicidade de problemas que são invisíveis para aqueles que estão fora do processo de design. Uma solução maravilhosamente intuitiva não funcionará se a arquitetura do sistema não der suporte a ela, ou se o código resultante ocupar muita memória ou "rodar" muito lentamente. Outros problemas surgem das capacidades básicas do homem e os requisitos necessários para que os usuários executem as tarefas que desejam. Não interessa se a interface responde instantaneamente se o usuário não pode usá-la. Soluções para um problema de interface exigem compromissos. Mas como um designer determina se um compromisso é aceitável ou não? Como os designers concebemnegociações aceitáveis entre velocidade e intuição e outros valores e requisitos aparentemente contraditórios?

A instabilidade dos requisitos tal vez seja a maior dificuldade ao se tentar fazer um design e um redesign de software à medida que ele cresce em escala e em tempo de vida. Para Jones a questão é "como chegamos a esta situação? Diff́cil de dizer, difícil de prever. Minha impressão mais forteé a de que a direção na qual os requisitos irão se modificar, tanto durante o design inicial quanto mais tarde, nãoé previsível nem a partir do conhecimento inicial de quem desenvolve nem de quem vai usar o software" [103].

Não só o número de requisitos aumenta a dificuldade de se projetar uma interface, mas a variedade de fontes que geram requisitos exigem que o design de uma interface, para ser bem sucedido, seja um processo multidisciplinar. Esta natureza multidisciplinar introduz problemas políticos. Psicólogos, designers gráficos, escritores, designers industriais e programadores poderiam dar contribuições essenciais ao design de uma interface. Mas cada uma destas áreas possui suas proprias prioridades e perspectivas, seus proprios métodos e seus próprios critérios para êxito. Muitas vezes eles estão em conflito uns com os outros. Quais prioridades são asmais importantes? Quais perspectivas são as mais valiosas? Quais critérios de êxito devem ser obedecidos? Conceber uma solução para os conflitos entre abordagens diferentes não é uma tarefa fácil.

Existem três razões que contribuem para que o design de uma interface seja difícil. Primeiro, é difícil encontrar boas soluções. Segundo, existem tantos anseios competindo nos problemas de uma interface que uma solução está associada a um compromisso. A questão aqui é de avaliação: como os designers decidem quais compromissos aceitar e quais evitar. A terceira razão para a dificuldade no design de uma interface é que o design é multidisciplinar e altamente político [60].

Dentro da produção de massa ainda existem grandes diferenças no custo e há muitos exemplos de grandes economias feitas através do redesign do produto para reduzir o uso de material, trabalho ou ferramentas especiais. Uma técnica formal para fazer isso, a análise de valor, foi criada por L. D. Miles nos anos 50, e foi utilizada com notável su- 


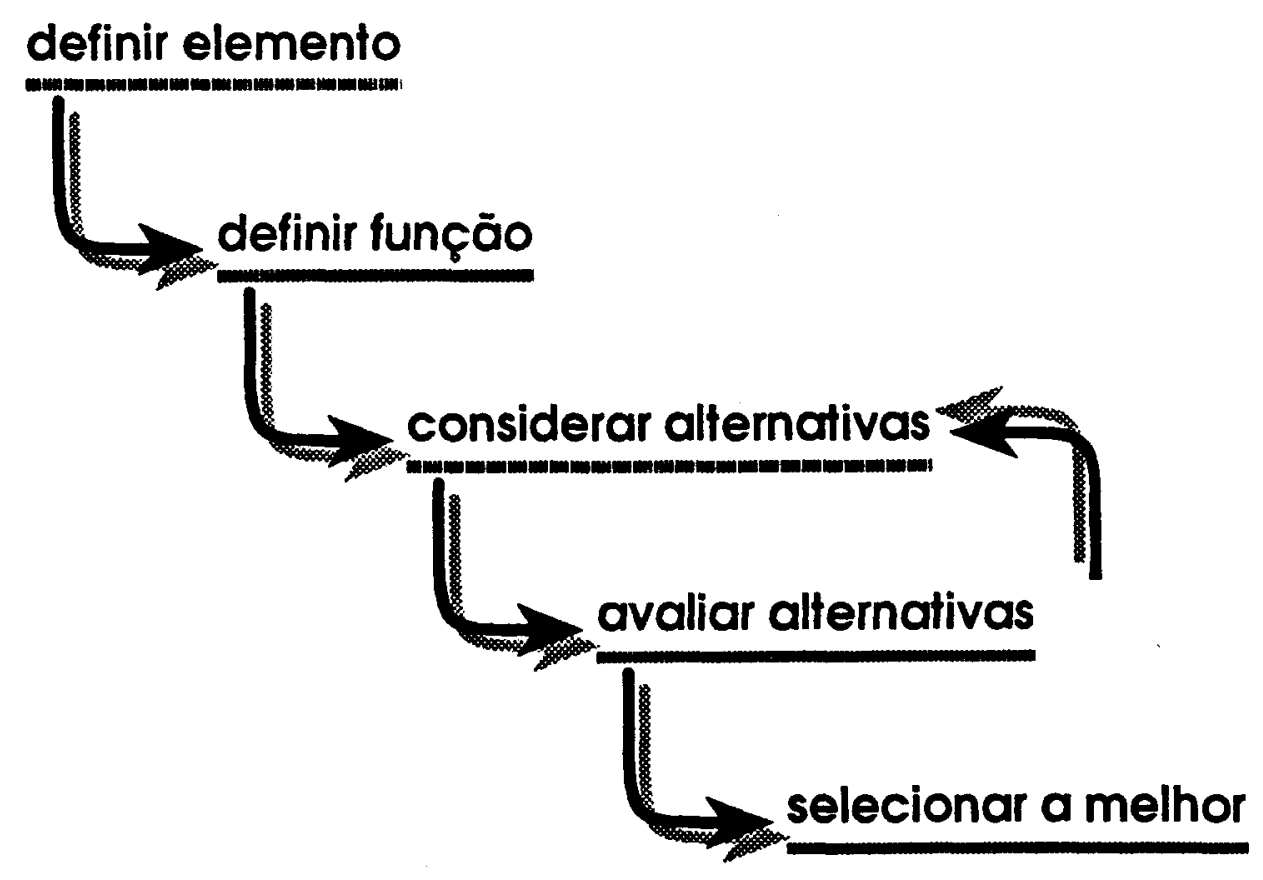

Flgura 3.1

As etapas tradlclonais de design do produto. cesso não apenas para reduzir custo mas também para racionalizar e aprimorar a performance funcional. A essência deste método amplamente adotado pelo design industrial é manter a atenção na função (veja Figura 3.1). A força deste método é que qualquer coisa estranha à sua execução pode ser identificada e descartada, dado que as funçóes de cada parte podem ser previstas e mantidas estáveis, utilizando-se o mínimo de recursos.

Esta abordagem pressupz̃e uma grande quantidade de informaç̃es sobre o ambiente do usuário, e sobre os efeitos causados no usuário por um sistema ainda não existente. Esta é uma abordagem top-down para o design, mesmo com a equipe de desenvolvimento sabendo que os objetivos e metas de um projeto modificam-se constantemente durante o desenvolvimento. $O$ que este tipo de modelo não leva em conta é que a introdução de um novo sistema modifica o ambiente de operação no qual se basearam os objetivos iniciais: $o$ ambiente para o qual o sistema foi criado não existe mais.

Mas existe um custo invisível, que só recentemente se tornou evidente. É aquele gerado pela inflexibilidade, super-especialização, a compreensão de que cada vez mais este "mundo plástico" de produtos homegeneizados e de baixo custo não pode ser alterado ou consertado, e impõem à sociedade (a partir da estabilização em alta escala das funções) uma vida, um jeito obrigatório de usar o que é feito, que é sentido como coercivo, não satisfatório, com um número cada vez menor de saídas para a individualidade. A lição é obvia (apesar de sua aplicação nem tanto): não estabilizar as funçōes [103].

$O$ ato de se elaborar um design modifica o mundo, $e$ apenas um modelo que incorpore feedback como um princípio básico será robusto o suficiente para a construção do sistema [45]. Mais do que isso, não apenas a solução deve aceitar modificações, mas também objetivos e metas. Muitos dos problemas do design e do desenvolvimento de software têm início porque não se permite que os requisitos sejam modificados conforme o projeto amadurece. Quando existe a possibilidade de se avaliar alternativas de forma iterativa , a única preocupação é que o produto final esteja o mais próximo possível da especificação original. A iteração serve apenas como uma ferramenta para atender as necessidades do problema que se quer resolver.

A conseqüência desta abordagem é que o sistema atende perfeitamente às especificações iniciais, mas é usado indiferentemente. Ao introduzir um novo sistema, uma nova estrutura, em um ambiente de trabalho, está se modificando o ambiente e tormando as especificações iniciais quase inúteis [45]. 


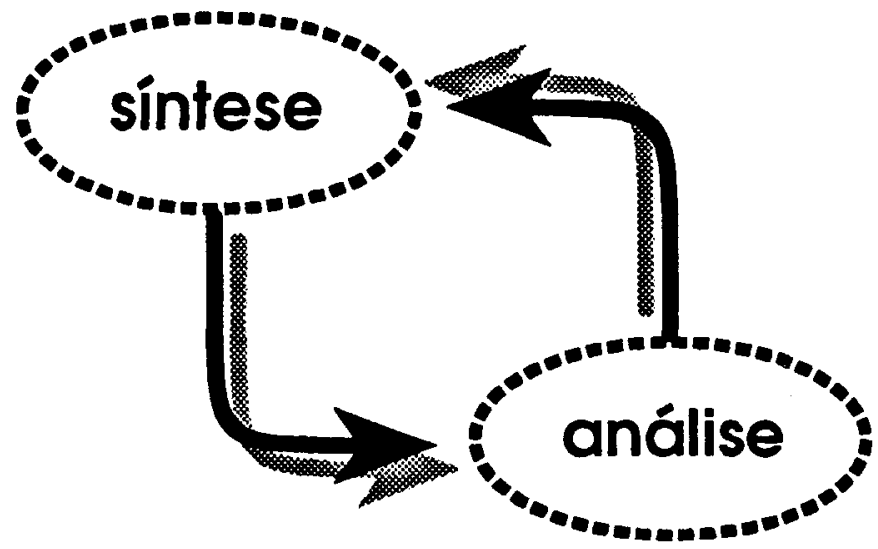

Cohill prefere, como abordagem a ser adotada tanto no design de sistemas quanto de interfaces, um processo centrado em um ciclo contínuo de síntese e análise (veja Figura 3.2). Na fase de síntese, o designer joga com as possiveis soluções, e, na fase de análise, avalia estas soluções a partir daquilo que sabe sobre o problema. A sintese e a especificação do problema ocorrem lado a lado, não sequencialmente. Assim, os sucessivos designs não reduzem o número de potenciais soluções. Ao contrário, cada nova tentativa é utilizada para se aprender mais sobre o problema. Uma possivel solução pode ser redefinir o problema. $O$ design, neste sentido, é um processo de exploração e uma atividade humana única que não pode ser facilmente explicada, categorizada ou empacotada em um conjunto de regras [45]. Lyytinen salienta que cada sistema de informação (e cada interface) pode exigir sua propria teoria e pesquisa [136].

Esta visão de design como processo não proíbe o uso de metodologias de desenvolvimento. Ela sugere, no entanto, que estas metodologias não sejam aplicadas cegamente a qualquer projeto de desenvolvimento. Estas metodologias devem ser escolhidas caso a caso, levando-se em conta 0 ambiente único onde será desenvolvido o sistema.

A principal diferença que as novas metodologias estão provocando é a de que buscam maneiras formais de pesquisar o problema mais profundamente, fazendo com que a interdependência entre problema e solução seja explorada e compreendida adequadamente. Não é fácil perceber, em qualquer exemplo, como e por que os requisitos iniciais podem ser mal-interpretados e que os requisitos atuais se existe a necessidade de um bom design também devem refletir o que se aprendeu enquanto o design acontecia. Mas é simples de se ver que, em princípio, a atividade do designé um processo altamente informacional (essencialmente um processo de se desaprender o que acreditamos seja o caso, mas que não é mais válido quando modificamos a situação ao fazer algo novo que interage com o que existia antes) e que sempre é prudente agir a partir da última informação disponível. "Se soubessemos, no início, o que aprendemos enquanto estávamos fazendo o design, nunca o fariamos da maneira que fizemos" [103]. A questão prática, a de usar os novos métodos de design para tornar possivel uma busca colaborativa divergente antes que os requisitos sejam fixados, é a de modificar a base do contrato (implícito) entre designers e usuários. Ambas as partes devem considerar o uso dos requisitos como uma base semi-legal para controle e medida, e concordar em trabalhar juntos no meta-processo contínuo da descrição inicial e partilhar a eventual decisão de como o problema deve ser visto e resolvido.

Dentro de todas as variáveis, o contex to do ambiente é a coisa mais diff́cil de se reconhecer, porque ele inclui as pessoas etambém sua forma de pensar.O contextoé a fonte de mudanças, do inesperado, o verdadeiro gerador de novidade, de design, e de evolução. As aspiraçōes, propositos, requisitos, e funçōes são as palavras que definem a maneira pela qual se vê o que é necessário modificar. Mas ao nomear o que precisa ser modificado, existe a tendência de se excluir a parte principal, a menos previsível: as pró-
Figura 3.2

Processo de design (cf. (45)). 
prias pessoas, suas mentes, e como elas se modificam quando vivenciam alguma coisa. As pessoas são o verdadeiro proposito do design, não as palavras. O maior erro de todos é considerar apenas o produto como aspiração máxima. Ele sempre é secundário.

Para Jones, o melhor tipo de evolução é a "(...) natural, baseada na linguagem, artesanal, não planejável mas altamente sensível a mudanças de contexto e com resultados surpreendentemente coerentes. Funções e definições de requisitos são essenciais mas temporários. Sem eles não podemos começar, mas enquanto não pudermos mudá-los, não podemos terminar, não podemos descobrir. A essência da natureza e evolução da linguagem é se adaptar gradativamente novas funções às já existentes, desprezando as antigas. Este processo quase que miraculoso só é possível quando o contexto é móvel, é sensível a novas funções para as partes que já existem, e não está preso d̀s funções antigas. Isto, a ampla escala de mudança que existe, supõe fluidez, não rigidez, em seu nível mais abstrato, na escala de seus desejos, fins" [103].

Assim, para um design contínuo, não se deve estabilizar as funções. Fixar as funções inibe a adaptabilidade humana, presente em cada um, da qual depende o design que permanece no tempo. Como, na prática, lidar com as mudanças nos requisitos e na especificação? Primeiro, reconhecendo que os requisitos "corretos" são, em princípio, desconhecidos pelos usuários, programadores ou designers desde o início. Deve-se delinear o processo de design, e os acordos formais entre designers, programadores, e usuários, para que sejam sensíveis ao que se está aprendendo por qualquer uma destas partes conforme o design evolui. Deve-se organizar a colaboração de maneira que cada pessoa envolvida tenha (a) a liberdade de experimentar e improvisar, e (b) os meios para testar suas improvisações para a operação do todo. A extensão de (a)e (b) pode variar enormemente de pessoa para pessoa mas deve ser, sempre que possível, de forma a prevenir mudanças destrutivas ou que sirvam para bloquear outras mudanças.

A colaboração na criação talvez seja o maior desafio deste final de século. Antes da computação ela não era possível, em princípio, na escala na qual a sociedade opera e está organizada: a escala dos bilhões e a escala da mente de cada um. Para Jones, “a tendência é que esta colaboração seja muito difícil, mas esta é, como acredito, a questão invisível por trás da busca por um design duradouro. A tentativa de agir juntos como se todas as coisas que fazemos sejam uma so, uma unidade. Como nos construimos. Mas uma unidade que nos deixa incrivelmente livres, para fazer ou estragar. Quais são os bloqueios para o design colaborativo? O que nos impede de atuar juntos como um contexto para nosso trabalho, nos adaptando livremente ao que descobrimos fazendo o que fazemos? Os bloqueiossãopensando-o-produto, fuxando-funcöes, fixando-papéis, reduzindocustos, e nossa identificacão de nós mesmos com estas coisas em vez de com nossos pensamentos, sensações, mentes, e consciência do senso comum do que é preciso mas para o qual nós não somos pagos. Tudo isto nos deixa dependentes do status quo (o qual identificamos com vendas, com segurança, quando de fato isto destrói nosso eu, o ser, a alegria de viver). Esta é a razão do porque, eu acredito, parecemos perder a adaptabilidade, a adaptabilidade biologica com a qual nascemos. O primeiro passo prático para o desbloqueio, para ter liberdade para ser criativo e colaborativo, é o de ampliar e sobrepor as especificações de nosso trabalho, de nossos papéis. Quando isso acontecer, todo o contexto começa a ficar mais maleável" [103].

Conforme grandes grupos começam a trabalhar juntos no design, é preciso não apenas ampliar os papéis mas também definir formas mais claras de divulgar o que se pensa. São necessários processos de design mais "visíveis" de maneira que qualquer um 
possa ver o que está sendo decidido, e porque antes, não depois, que as principais decisões tenham sido tomadas. Talvez a colaboração realizada antes de se fixar os conceitos seja a principal força dos novos métodos de design. Outra força é fornecer meios para uma desaprendizagem, pública, sem formas pré-definidas ou fixadas.

A atenção para o contexto, não para a auto-expressão, é a habilidade que deve ser encorajada e partilhada. Na evolução natural, a falta de atenção significa a morte. O contexto, e não o patrão, deve se transformar no administrador do que deve ser feito, e como deve ser feito. $O$ papel dos patrões se transforma naquele de criar o meta-processo, criar a situação para que o design cooperativo seja possível, para que ele flua. $O$ design cooperativo é a interseção do que cada um está percebendo com o que cada um está fazendo. Apenas desta maneira se pode descobrir como restruturar a situação de design de forma que os bloqueios sejam removidos, e para que as iniciativas que permitem uma autocorreçâo sejam encorajadas. $O$ primeito passo consiste em modificar a base contratual de colaboração entre designers, equipe de desenvolvimento, usuários, todos os envolvidos: tornar esta base independente de funções e requisitos. Estabelecer um melhor nivel de acordos.

Como, em princípio, o contexto, a situação de design deve ser organizada se tudo isso for possível? $O$ desejo geral é permitir que todos os envolvidos possam ter iniciativas a luz de um conhecimento preciso dos efeitos do que cada um está fazendo. Na prática isto parece muito dificil. Jones sugere que se comece "pela ampliação das especificações de maneira a permitir que rascunhos não profissionais possam ser aceitos nas improvisaçбes de qualquer dos grupos envolvidos, e a adotar padrões profissionais sempre que eles pareçam ter importância local enão universal. Em segundo lugar, eu tentaria progressivamente evitar a necessidade de comunicação forçada via manuais, encontros, memorandos, etc. - , e buscaria cada vez mais pelo tipo de colaboração informal que é possível com a evolução do uso da linguagem" [103].

Cohill sugere cinco princípios que formam a fundamentação filosofica para o design de um sistema ou de uma interface [45]:

- Design é um processo; ele é circular, repetitivo e imprevisível.

- Design é pessoal e idiossincrático; é um processo que só pode ser aprendido através da exploração e experiência pessoais; ele não pode ser ensinado.

- Design é um ato de exploração; ele é orientado a feedback, requer uma tendência para mudanças, e requer uma sensibilidade para a estética do produto final.

- A arquitetura da informação está preocupada com os ambientes informacionais; estes ambientes podem ser representados como estruturas auto-incluídas e auto-regulatórias compostas por elementos definidos por relaçð̃es de interconexão.

- Os elementos de uma estrutura de informação são os computadores (hardware e software), as pessoas, e os ambientes físico e social no qual computadores e pessoas se comunicam.

A partir destes princípios e da nova prática de design apresentada neste capítulo, pode-se esboçar quais as origens e principais características de um programa de pesquisa na área de design cooperativo. 


\section{Base conceitual para o design cooperativo}

O humor sempre teve um papel muito importante na sociedade. Neste caso, uma imagem vale mais do que mil palavras.

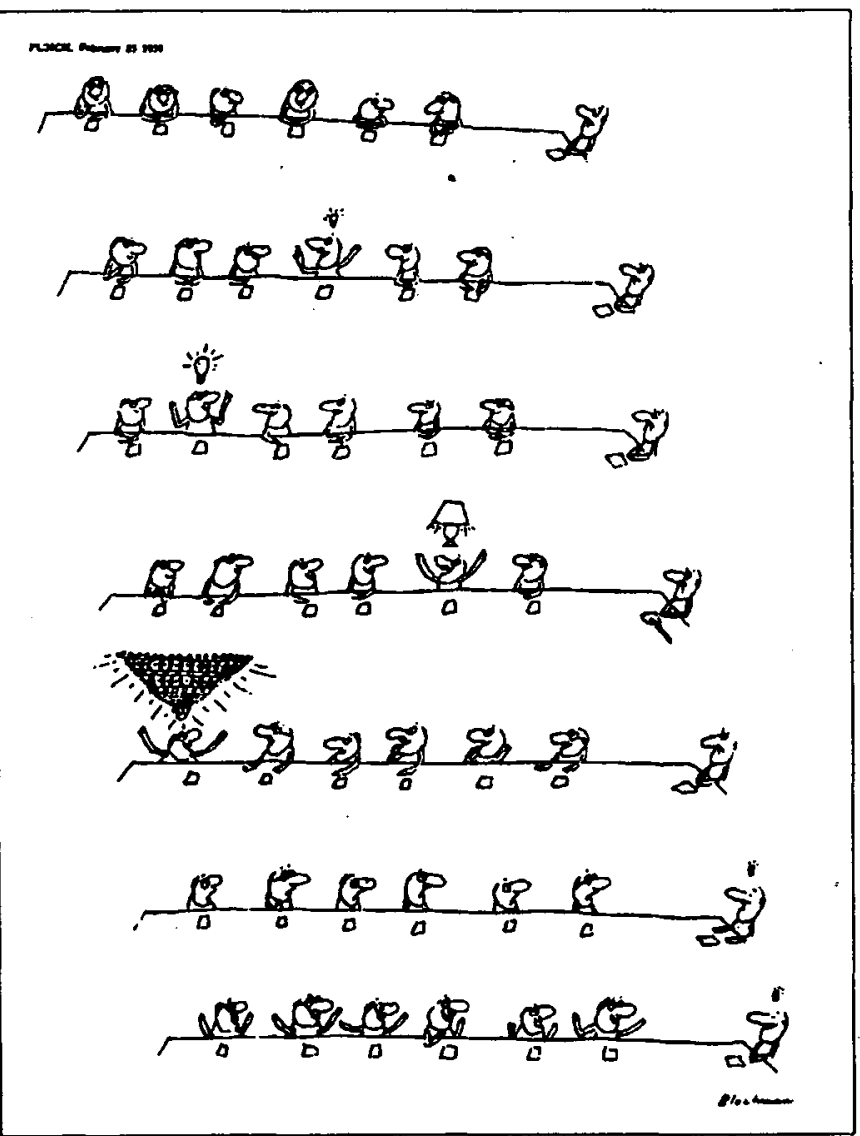


É evidente que, enquanto não ocorrer a automação completa de processos, sempre irá existir a necessidade de algum tipo de intervenção humana. A divisão do trabalho entre seres humanos e máquinas se transforma, portanto, em uma tarefa muito importante. Tradicionalmente, na área de fatores humanos, esta tarefa de "alocação de funções" ocorre de acordo com um conjunto de princípios sobre as capacidades de performance das pessoas e das máquinas em geral. Também se faz necessária uma "interface" entre a máquina e a pessoa - alavancas, mostradores, monitores, controles — de maneira a que possa haver interação em algum nível. No inf́cio do século, a atenção estava voltada para se conseguir a desejada funcionalidade. Muitas vezes a componente humana ficava reduzida a mais um "aprendiz" do maquinário geral — um que, às vezes, poderia ser sacrificado sem prejurzo. O lento aperfeiçoamento das condiçôes e natureza do trabalho das pessoas que operavam estas máquinas surgiu não por razões altruísticas, mas principalmente pela busca de uma maior eficiência na operação. Operadores mal treinados e pouco motivados, e equipamento mal desenvolvido poderiam causar colapsos no delicado funcionamento do processo industrial. Controles e tarefas melhor planejados que reduzissem o desgaste físico e mental do operador permitiriam uma melhor performance do sistema homem-máquina.

A tentativa de adequar a máquina às habilidades e limitações, tanto físicas quanto mentais, do operador levou ao desenvolvimento de um novo campo de estudos aplicados. O novo campo foi chamado de engenharia de fatores humanos nos Estados Unidos, e esforços similares na Europa ficaram conhecidos como ergonomia, das palavras gregas ergon, trabalho, e nomos, lei ou conhecimento. As pessoas que trabalham neste campo geralmente possuem uma formação em ciências do comportamento ou engenharia industrial. Fisiologistas e médicos também contribuiram para a compreensão das capacidades e limitações humanas em ambientes de trabalho - efeitos do stress, habilidades psico-motoras, acuidade perceptiva, carga de processamento mental, etc. A partir desta disciplina observacional e ocasionalmente experimental nasceu um corpo de conhecimento que pode ser útil para o design de complexos sistemas homem-máquina .

No início do século o problema consistia em construir máquinas úteis para alguma coisa: o foco estava na performance da máquina. Como as máquinas não eram modificadas durante longos períodos de tempo, a facilidade de aprendizado também não era uma prioridade. $O$ treinamento era um processo "de uma tacada s6": as pessoas eram treinadas para as tarefas exigidas e subsequientemente serviam como operadores das máquinas. Conforme a computação evoluiu - um resumo desta evolução foi apresentado na Introdução desta dissertação - , a separação entre a operação e a programação se desenvolveu. $O$ foco continuava sendo a funcionalidade do software ao invés da facilidade de uso. Para Bannon, "os programadores gastam anos aprendendo uma linguagem misteriosa para poderem se comunicar com o sistema. [Mas] a comunidade de usuários começou a mudar de uma onde o foco estava seja no estudo das propriedades das máquinas seja na programação de aplicativos para uma onde o foco está em intermediar as necessidades do usuário e o sistema computacional. Um crescente número de pessoas usando computadores (...) se vê como alguém que possui um emprego ou profissão que não está relacionado diretamente com o computador, mas que diretamente se utiliza dele como uma ferramenta em seu trabalho diário. No entanto, estas pessoas se frustavam pela dificuldade de aprender como programar um computador para poder realizar seu trabalho. Com o surgimento dos computadores pessoais (...), tornou-se evidente que a sua aceitação dependia cada vez mais da facilidade de aprendizado e uso" [7]. 
O campo de estudos da interação homem-computador (human computer interaction, ou $\mathrm{HCI}$ ) surgiu no início dos anos 80 parcialmente como uma resposta a estas mudanças. A área estava ligada, de maneira um pouco distinta, ao seu "progenitor" fatores humanos tanto do ponto de vista de composição eclética quanto de fundamentos teoricos. O campo de estudos mais velho, às vezes chamado pejorativamente de "psicologia de alavancas e mostradores", não fornecia uma boa motivação para os cientistas cognitivos. O que se procurava era um melhor acoplamento cognitivo entre um ser humano e a nova máquina universal, o computador, e não apenas características superficiais melhor desenvol vidas. A engenharia de software também se envolveu, já que se estava iniciando o design de interfaces altamente interativas além de estarem preocupados com a construção de diálogos com os usuários e com a apresentação de informações complexas em displays gráficos. Durante a última década, a área de HCI cresceu enormemente, tanto dentro dos ambientes de pesquisa acadêmicos quanto nos laboratórios das empresas. Esta preocupação comercial contribui para o ímpeto dos estudos na área, e "facilidade de uso" e "amigável" passaram a servir de propaganda para alguns sistemas computacionais.

\section{Substituindo fatores humanos por atores humanos}

Muitas vezes, os termos utilizados em uma disciplina fornecem pistas de como os membros "veêm" a própria área. No entanto, uma vez que certas distinções são aceitas e passam a fazer parte do vocabulário padrão, estes termos podem servir como barreira para a realidade que ficou do lado de fora. Por esta razão, é um exercício útil reexaminar periodicamente a linguagem utilizada para expressar o conhecimento sobre o mundo. Para Bannon [7], o uso dos termos fatores humanos e atores humanos destaca uma importante diferença na maneira de perceber uma pessoa: o primeiro dá a conotação de um indivíduo passivo, fragmentado, despersonalizado e não motivado; o segundo conota alguém ativo, com o controle nas mãos. Bannon enfatiza que "a pesquisa tradicional em fatores humanos, apesar de indubitavelmente possuir mérito e ter produzido diversos aperfeiçoamentos para os sistemas tecnológicos existentes, muitas vezes é limitada em escopo com relação à sua visão de uma pessoa. Na abordagem da área de fatores humanos, os seres humanos muitas vezes são reduzidos a apenas outros componentes de um sistema com características específicas - como concentração limitada, memória deficiente, etc. - que precisam ser fatorados dentro da equação de design do sistema homem-máquina como um todo". Como conseqüência, esta postura deixa questões muito importantes para o design do trabalho em segundo plano. A motivação individual, a participação em uma comunidade de trabalhadores, e a importância de se determinar uma ação humana são apenas algumas das questōes ignoradas. As pessoas são mais do que a soma das partes: sejam subsistemas processadores de informação ou sistemas fisiologicos, as pessoas possuem um conjunto de valores, objetivos, e crenças sobre a vida e o trabalho. Ao usar o termo atores humanos, a idéia de Bannoné colocar ênfase na pessoa como um agente autônomo que possui a capacidade de regular e coordenar seu próprio comportamento, ao invés de ser simplesmente um elemento passivo em um sistema homem-máquina.

Repensando o conceito de "usuário". Outro termo ambígüo nos artigos da área de HCI é o de "usuário". O termo genérico se refere a todas as pessoas que utilizam um sistema ou aplicação computacional em particular. $O$ foco de atenção da equipe de desenvol- 
vimento ou do grupo de pesquisa em HCI geralmente está associado à tecnologia. Já o ponto de vista das pessoas geralmente é o de "usuários" desta tecnologia e o de "usuários novatos" dela. No entanto, as pessoas podem não conhecer a tecnologia, mas elas não são novatas em seu trabalho; na verdade, os designersé que são "trabalhadores novatos". Bannon [7] acredita que "existe um grande perigo em pensar nas pessoas apenas como usuários. De fato, muitas vezes ocorre que os usuários de computadores têm que fazer algumas modificações no sistema, de forma a adequá-los antes que possam ser realmente usados. Assim, na realidade, os usuánios também são designers". Pensar nos usuários apenas como pessoas pode também fazer com que se ignore que a visão que 0 usuário tem da tecnologia que está sendo desenvolvida pode ser bem diferente da visão do designer. O usuário geralmente é um trabalhador que tem um conjunto de tarefas para realizar, e o uso do computador pode ser apenas um elemento necessário para que ele possa realizar o trabalho. Em um ambiente de trabalho, o usuário está envolvido com múltiplas tarefas não apenas no computador, mas também com os colegas, clientes e fornecedores. Para Bannon, "negligenciar este conjunto rico e complexo de banalidades mas de reais interações de trabalho cotidianas pode levar a sistemas inoperáveis ou diffceis de manejar. É justamente esta habilidade de compreender a perspectiva do usuário, de ser capaz de ter empatia e trabalhar com os usuários do futuro sistema que diferencia a boa equipe de desenvolvimento"'.

Os usuários não são idiotas. Se tomar o usuário como um novato já é ruim o suficiente, vê-lo como um idiota é ainda pior. Existem enormes implicações para o design se esta maneira de ver o usuário for adotada, mesmo que implicitamente. Bannon destaca que, "apenas porque os usuários não compreendem como a máquina trabalha ou têm dificuldade com a terminologia adotada pelo designer, isto não implica que eles sejam estúpidos, como algumas equipes de desenvolvimento parecem concluir, se podemos julgar por alguns sistemas criados. A equipe de desenvolvimento deve começar pela compreensão de que os trabalhadores/usuários são profissionais competentes, pessoas com tarefas e relacionamentos de trabalho que devem ser levados em conta durante o design de um sistema, e com os quais precisam colaborar de maneira a desenvolver um sistema apropriado. A idéia de que precisamos desenvolver sistemas tais que qualquer idiota possa usar merece ser olhada de perto. Levando este objetivo de design a sério muitas vezes pode resultar em sistemas que produzem necessariamente este comportamento estúpido. Felizmente, parece que este problema em particular está diminuindo, provavelmente como resultado de uma maior compreensão por parte dos designers sobre a perspectiva dos usuários". Uma versão um pouco mais sutil desta questão é a da ênfase dada na "facilidade de aprendizado": certamente, existem algumas aplicações onde a facilidade de aprendizado é desejável, mas isto não é necessariamente assim quando se trata de sistemas que serão utilizados cotidianamente durante o trabalho.

Permitir usuários ativos. Mesmo sendo um passo positivo focar a atenção nos usuários, eles não são simplesmente objetos passivos que podem ser estudadose para os quais se faz um design. As pessoas são, ou podem vir a ser, agentes verdadeiramente ativos. Muitas vezes eles desejam realizar uma tarefa, compreender o que está acontecendo, e tomam a iniciativa exploram um sistema computacional por sua conta se, por exemplo, o tutorial for pedante ou obscuro. Se o sistema não fornecer uma explicação para o seu
1. Segundo Grudin (79). "o termo interface com o usuario (user-interfoce) começou a ser usado quando o desenvolvimento de sistemas era bem diferente do que éhoje. Naquele momento. o termo possula um proposito útil. (...) Perpetuar o uso atual (do termo) pode reforçar $\theta$ nos ligar a uma perspectiva obsoleta, $e$ isto pode Inibir sutil $\theta$ indiretamente a adoçáo de novas areas de pesqulsa e novas abordagens parao desenvolvimento". Mais adiante. complementa dizendo que "a terminologia orlginada em um ambiente de engenharia obscurece sistematicamente as mudanças que ocorreram na forma de desenvolver e usar as interfaces. (...) Assume-seo computador como ponto pacíflco: o usuário precisa ser especificado. (...) Os termos (utillzados para se referir a interface) simplesmente assumem que tudo está centrado no computador". Veja tamberm, Greenbaum \& Kyng (72), pp. 20-21. 
comportamento, o usuário muitas vezes tenta encontrar uma de maneira a tornar o sistema compreensível. As pessoas estão sempre tentando dar sentido ao seu mundo. Desenvolver seqüências de instruções para serem seguidas ao acaso, com explicações inadequadas, não satisfazem ou mesmo funcionam em situaçðes reais.

Em resumo, como afirma Bannon, "alguns dos conceitos e termos comuns às áreas de design de sistemas e pesquisa em HCI contêm pelo menos uma perspectiva implícita, se não explícita, dos usuários de sistemas computacionais que eu afirmo ser imprecisa e tendenciosa o suficiente para levar a decisões errôneas de design. Da mesma forma, dentro das áreas de teoria e pesquisa em HCI, esta perspectiva levou a uma concentração em questões que são estudadas em laboratório às custas de outras preocupações que podem ser mais cruciais em um local de trabalho".

\section{Além das atuais concepçðes de $\mathrm{HCl}$}

Apesar dos vários avanços que ocorreram em điversas áreas da interação humana (veja [202] para um resumo de alguns destes avanços), existe uma séria crítica com relação d suposta falta de relevância dos estudos de HCI para os profissionais em design de sistemas. Mesmo com todo o interesse, nenhum conjunto evidente de princípios surgiu a partir dos trabalhos na área. A experiência de certos designers foi codificada de maneira vaga, várias listas de guidelines para design estão disponíveis, e foi produzido um grande número de avaliações de sistemas já existentes; mas se tem encontrado dificuldades para colocar esta ciência aplicada em um formato mais rigoroso.

Alguns dos sofisticados métodos e técnicas usados em psicologia para analisar o comportamento do usuário poderiam ser utilizados, de maneira que os designers pudessem descobrir qual a performance dos usuários em diferentes versões de um sistema, ou de diferentes protótipos, permitindo que os designers não precisassem se basear na intuição. No entanto, os tradicionais experimentos de laboratório são muito limitados, caros, e demorados. O que se precisa são métodos rápidos e concisos que forneçam feedback imediato para os designers sobre a utilidade e a usabilidade de seus produtos. Atualmente, isto está acontecendo na prática nos trabalhos sobre usabilidade. $O$ design de um sistema envolve várias tomadas de decisão, e em muitas ocasióes dados empíricos podem auxiliar na determinação das escolhas apropriadas. Tarefas como estudos sobre o ambiente de trabalho, sobre reaçôes, preferências, protocolos verbais para a descrição das aplicações, etc. são métodos investigativos familiares aos psicólogos que podem ser úteis em um processo iterativo de design.

Os psicólogos cognitivos também estudaram questões particulares como, por exemplo, a maneira pela qual as pessoas aprendem a usar processadores de texto, quais os principais tipos de erros e os modelos mentais que elas constroem. No entanto, aplicar este conhecimento em outras situações não é necessariamente óbvio. Da perspectiva do designer, o que se fez até hoje pode colocar em evidência algumas questões pertinentes, mas ainda serão necessárias muitas contribuições para que a busca por novas maneiras de pensar e desenvolver sistemas possa amadurecer. Bannon acredita que "a esperada contribuição da área de HCI para o design de interfaces completamente novas ainda não se materializou" [7]. 
Para este autor, "existe um grande número de limitações em muitos dos atuais trabalhos de HCI que poderiam ser remediados para que a área pudesse ser mais útil aos designers em situações práticas". Ele sugere algumas mudanças de curso na pesquisa em HCI, "com o intuito de fornecer uma ponte entre teoria, experimentos, design de sistemas e o atual ambiente de trabalho" [7].

Do produto para o processo na pesquisa e no design. Isto significa que se deve dar maior atenção ao processo de design (veja especialmente [63] e [103]), trabalhando-se com os usuários em todos os estágios do design, vendo a natureza iterativa do design e as alterações na concepção do que se está desenvolvendo como um resultado do próprio processo. Esta é uma maneira de ver o design que está em desacordo com a forma tradicional de se proceder, que parte de um conjunto fixo de requisitos sem iteração e sem o envolvimento dos usuários.

Do indivíduo para o grupo. A maior parte dos estudos em HCI se dedica ao usuário individual trabalhando em um sistema computacional. Este foco de pesquisa negligencia totalmente a importância da coordenação e da cooperação entre processos de trabalho que é tão necessária em diversas situações. Novamente, a área aplicada foi mais esperta do que a teórica. Os designers de sistema têm estado conscientes deste aspecto coordenativo da atividade de trabalho e têm tentado dar apoio a ele desde o início, mesmo que rudimentarmente. Por exemplo, a pesquisa sobre automação de escritórios da década de 70 tentava modelar o fluxo de trabalho, mas de uma maneira muito rígida, não permitindo aos "componentes" humanos flexibilidade suficiente para que o sistema funcionasse. A partir do trabalho de Suchman (principalmente [215]), desenvolvido durante a década de 80, os designers conseguiram um "modelo" aprimorado para poder construir seu sistema. A palavra "modelo" está em aspas, porque esta pesquisa indicou que, na maior parte das situações de trabalho, não é possível nem desejável um modelo da ação humana. Ao invés disso, a ação humana é dirigida pela situação concreta que existe em qualquer momento e que está se modificando constantemente. Isto implica em que se deve dar apoio aos trabalhadores em suas atividades, ao invés de construir sistemas de automação de escritorio. Estender o foco de atenção da dualidade homem-computador para grande grupos de pessoas e máquinas engajadas em tarefas colaborativas é uma importante área de pesquisa para as próximas décadas ${ }^{2}$.

Do laboratório para o trabalho. Muitas pesquisas realizadas anteriormente em HCI estavam confinadas a pequenos experimentos controlados, com o pressuposto implícito de que as descobertas poderiam ser generalizadas para outras configuraçðes. No entanto, tornou-se cada vez mais evidente que estes estudos sofriam de uma variedade de problemas que limitavam a sua utilidade em qualquer configuração prática. Primeiro, quando estes estudos terminavam, a tecnologia já havia tornado sem valor suas preocupações. Importantes detalhes contextuais para a finalização de tarefas eram muitas vezes omitidos na transferência do mundo real para o laboratório, de tal forma qua os estudos de laboratório dificilmente poderiam ser aplicados em outros contextos. Cada vez mais se fortaleceu a tendência de dar atenção aos estudos in situ, em uma tentativa de se "captar" a complexidade das situações do mundo real, e uma grande variedade de técnicas de observação, especialmente vídeo, estão sendo usadas com este fim. Pode-se notar um
2. Veja, por exemplo. (34), (62). (69), (74), (78), (84), (115), (120). (132), (139), (154), (190). (191), (211), e (229). 
aumento de interesse no conceito de "usabilidade" entre a comunidade de pesquisadores - se as pessoas podem e conseguem usar os sistemas desenvolvidos para elas. Para 0 designer, isto significa que é necessária a existência de um protótipo ou de um sistema de teste para os usuários experimentarem o produto, de maneira a se obter informações sobre a usabilidade do sistema resultante.

Do novato para o especialista. A maior parte dos estudos experimentais em HCI restringiram sua atenção a pessoas que estavam aprendendo a usar um sistema ou aplicativo pela primeira vez. Geralmente, a performance é monitorada na primeira ou segunda hora de uso do sistema. Excepcionalmente, o uso de um aplicativo é observado por alguns dias, mas raramente por periodos maiores, como semanas, nem pensar em anos. Apesar de garantir que existe a necessidade de se estudar estes usuários, é merecedora de destaque a escassez de estudos que se preocupam com o processo de desenvolvimento de "expertise". A questão não se refere apenas à performance do especialista, mas parece ser necessário dar maior atenção a maneira pela qual os usuários desenvolvem sua habilidade de usar um aplicativo ou sistema. Quais são os obstáculos ou incentivos que existem dentro de um sistema para encorajar o aumento de competência? Outras questões se relacionam com a diferença em aprendizado e uso do sistema por novatos universitários e grupos de trabalhadores específicos com suas práticas de trabalho já estabelecidas.

Da análise para o design. As primeiras pesquisas em fatores humanos possuiam a tendência de centrar a atenção apenas nos sistemas existentes, e analisar apenas as virtudes que foram encontradas na situação de uso, classificando-as como boas ou más do ponto de vista do usuário. No entanto, atualmente a maior preocupação dos pesquisadores de HCl é a de como construir melhores sistemas computacionais. Não estão interessados em conhecer os sistemas depois que foram construídos, desejam saber como construir os sistemas e mesmo o quê deve ser construído. A questão é a de como a área de $\mathrm{HCl}$ pode contribuir para o design de sistemas mais úteis e mais fáceis de serem usados. Segundo Bannon, alguns pesquisadores - principalmente Allen Newell e Stuart Card defendem a importância de se fornecer modelos aproximados de como as pessoas executam tarefas para serem utilizados nas escolhas de design sobre a interface com o usuário. São exemplos desta abordagem os trabalhos baseados no modelo coms ("Goals, Operators, Methods and Selections rules") e os modelos ainda mais generalizados como o de Pum ("Programmable User Models"). Estas abordagens, no entanto, ao invés de aproximar os designers dos usuários, parecem, como enfatiza Bannon, "apoiar a visão de que o contato com os usuários reais não é necessário".

Do design centrado no usuário para o design com o envolvimento do usuário. Nos últimos anos, ocorreu uma crescente ênfase no uso de uma abordagem "centrada-nousuário" para o design de sistemas e interfaces, particularmente como forma de chamar a atenção do designer para as necessidades do usuário (veja [175]). No entanto, o significado exato da expressão "design de sistema centrado no usuário" ainda não foi bem definido. Em alguns casos, a expressão significa apenas "conhecer o usuário". Mas, como aponta Bannon, "este tipo de princípios generalizadas é de pouco aux́lio nas situações práticas de design devido à sua falta de especificidade" [7]. Alguns autores (por 
exemplo, [4], [22], [49], e [81]) destacam a importância de se ter logo de início a atenção voltada para o usuário, a de se desenvolver designs iterativos, e a de se ter testes contínuos com usuários o mais rápido possível. O resultado aparente é o de que os usuários parecem estar assumindo cada vez mais um papel decisivo no processo de design. No entanto, este papel aindaé o de uma participação passi va onde, apesar deser mencionada, ela não parece ser a atividade mais importante. Para Bannon, "uma abordagem mais radical dentro das atuais linhas de pesquisa em $\mathrm{HCl}$ é a de se olhar para os usuários não apenas como objetos de estudo, mas como agentes ativos dentro do próprio processo de design. $O$ envolvimento do usuário serve tanto como uma forma de promover a democratização no processo de mudanças nas organizações quanto como uma maneira de assegurar que o sistema computacional desenvolvido esteja adequado ds necessidades dos usuários".

Da especificação formal dos requisitos para a prototipagem iterativa. Cada vez mais está se chamando a atenção para a inadequação da forma padrão de se representar as necessidades do usuário no documento de especificação funcional dos requisitos. Por esta razão, os designers estão se perguntando se o problema está na forma de se fazer os estudos localmente, ou se existe, na verdade, um problema mais fundamental no proprio pressuposto de que é possivel mapear antecipadamente os requisitos e necessidades do usuário através apenas de técnicas de obser vação e entrevista. Para Bannon, "os usuários precisam ter a experiência de estar na situação futura de uso, ou em uma boa aproximação dela, para serem capazes de comentar as vantagens e desvantagens do sistema proposto. Assim, algum tipo de réplica ou protótipo deve ser constrúdo de maneira a permitir que os usuários conheçam como deverá ser a situação futura de uso". Esta questão, em particular, é parte da reorientação de produto para processo tanto na pesquisa quanto no desenvolvimento de sistemas.

\section{Design situado: ideais adotados}

Em 1985, a Aarhus University, na Dinamarca, sediou uma conferência sobre Computadores e Democracia [16], que serviu como prosseguimentodo trabalho de quase uma década sobre o envolvimento dos pesquisadores em projetos de design escandinavos centrados-no-usuário. Seis anos mais tarde, Greenbaum \& Kyng editaram um livro [73] que retrata $o$ atual estágio de muitas das pesquisas e projetos que se seguiram à conferência de Aarhus, destacando principalmente a experiência dos autores no que se refere à evolução da idéia de trabalhador-como-usuário participante ${ }^{3}$.

Um subproduto destes encontros pode ser descrito por um conjunto de ideais de design que, de uma ou outra forma, são adotados por estes pesquisadores e servem de referência para seus trabalhos. Os ideais podem ser descritos como [72]:

- Os sistemas computacionais que são criados para o local de trabalho precisam de um design com a total participação dos usuários. Total participação, é claro, exige treinamento e cooperação ativa, e não apenas representação proforma em encontros e comitês.

- Quandoos sistemas sãocolocados nolocal de trabalho, eles devem aprimorar as habilidades de trabalho ao invés de degradá-las ou racionalizá-las. Aprimorar habilidades significa prestar atenção a certas coisas que geralmente
3. Para um apanhadohlstórico dos primelros projetos desenvolvidos pelos sindicatos, veja (65). Para um levantamento destesprojetos euma discussáo sobre sua importôncla para os projetos atuals, veja (44). Para um quadro sinóptlco de diversos projetos. suas principais caracteristicas, $\theta$ quals técnicas foram/estóo sendo utilizadas, veja (157). 
são deixadas de lado pela especificação formal, como respeito pelo conhecimento tácito, construção do conhecimento partilhado pelo grupo, e, mais importante, comunicação. Os sistemas computacionais são muito mais do que o simples fluxo de informação representado nos fluxogramas que os analistas apresentam aos clientes.

- Os sistemas computacionais são ferramentas, e precisam ser criados para estar sob o controle das pessoas que os usam. Eles devem facilitar as atividades de trabalho e não torná-las mais rigidas ou racionalizadas.

- Apesar dos sistemas serem adquiridos com o proposito de aumentar a produtividade, eles também devem ser vistos como uma forma de aumentar a qualidade dos resultados. Maior número de páginas sendo produzidas por um sistema administrativo não significa melhor saída. A dupla énfase em produtividade e qualidade traz novas questôes para o processo de design. - O processo de design é um processo político e inclui conflitos em praticamente todas as suas etapas. Os administradores que solicitam o desenvolvimento do sistema podem ter diferenças com os trabalhadores que irão usar o sistema. Grupos de usuários diferentes irão precisar de aspectos diferentes do sistema, e os designers muitas vezes representam apenas os seus próprios interesses. Conflitos são uma parte inerente do processo. Se eles forem deixados de lado ou ignorados na tentativa de rapidamente se obter um sistema que possa ser usado, o sistema pode ser dramaticamente menos útil e continuar a criar problemas.

- O processo de design põe em destaque a questão de como os computadores são usados no contexto da organização de trabalho. A questão de olhar com atenção o modo de uso dos computadores, chamada de situação de uso pelos pesquisadores escandinavos, éo ponto de partida fundamental para o processo de design.

Este conjunto de ideais formam a base da abordagem emergente chamada design cooperativo.

\section{Usuários como profissionais competentes}

Para muitos designers de sistema, a idéia de usuário significa alguém-sentado-nafrente-de-um-computador. A palavra usuário retira todo vestígio das atividades de trabalho implícitas e coloca o computador como centro das atençóes, jogando as pessoas para um canto indefinido. Parafraseando Wittgestein (citado em [72]), se um usuário pudesse sair desse background indefinido, será que os designers conseguiriam enxergálo? Geralmente, o usuário é visto a partir da ótica do designer. Seu trabalho é visto a partir dos conceitos de desenvolvimento dos designers, onde o conhecimento e a experiência do usuário com o trabalho que está sendo realizado são totalmente desprezados. A resposta para a paráfrase é a de que os designers nunca iriam enxergar o usuário, porque eles não possuem uma prática comum. Mas, felizmente, alguns designers acreditam que existem boas possibilidades para que ocorra uma compreensão mútua entre designers e usuários. No entanto, esta não é uma situação dada a priori, mas algo que precisa ser cuidadosamente desenvolvido. 
Apesar do domínio aparente das questões sobre a identificação do usuário na literatura de HCI, a preocupação geral é de como melhor "integrar o usuário" no processo de desenvolvimento de sistemas. Greenbaum \& Kyng, entretanto, destacam que "se colocam à parte [desta preocupação] (...) Nosso interesse não é o de adequar o usuário a um processo de desenvol vimento de sistemas já existente, mas sim o de criar novas formas de se trabalhar em conjunto. Para nós, a participação do usuário não significa entrevistar uma amostra de usuários em potencial ou juntá-los para repetir um conjunto de especificações. Ao contrário, chamamos de designo envolvimento ativo dos usuários no processo criativo". E acrescentam que "não [veêm] os usuários como um grupo homogêneo, mas como diversos grupos de pessoas que possuem competência nas suas práticas de trabalho" [72].

Por enxergarem as pessoas que usam computadores como competentes em sua própria área de trabalho, Greenbaum \& Kyng descobriram que "o ambiente de trabalho toma a forma de uma rica tapeçaria, profundamente permeada de complexidades e habilidades". Ao examinar essa tapeçaria, estes autores encontraram quatro padrões subjacentes:

- a necessidade dos designers levarem a sério aprática de trabalho dos usuários;

- o fato de que se está lidando com atores humanos, e não fatores humanos predeterminados ou apriorísticos;

- a idéia que as tarefas de trabalho precisam ser vistas dentro de um contexto e, portanto, são ações situadas; e são, tal vez, as mais importantes, já que fazem a conexão com as outras ações dentro do ambiente de trabalho;

- o trabalho é fundamentalmente social, envolvendo extensa cooperação e comunicação.

O último padrão - que indica o foco de atenção na natureza social da prática de trabalho --, sugerem os autores, mostra que "devemos nos tornar conscientes da natureza cooperativa das tarefas do ambiente de trabalho. Nosso interesse em atividades cooperativas não significa que glorificamos a forma como as pessoas trabalham umas com as outras, mas, ao contrário, nos força a olhar para o modo como as pessoas de uma organização criam, usam e modificam informação, conhecimento, e tarefas. Poucas tarefas de trabalho são feitas de maneira isolada, e um número menor ainda pode ser descrito facilmente. Enquanto o desenvolvimento tradicional de sistemas trata tarefas como um processamento de dados formalizável feito por pessoas isoladas, comunicando-se através de canais de dados, a premissa básica de nossa abordagem procura olhar para grupos interagindo de diversas maneiras dentro de contextos organizacionais muito complexos. E, pela mesma razão, apesar dos métodos tradicionais exigirem a descrição destas tarefas, nossa abordagem está baseada na crença de que o complexo padrão da vida organizacional não pode ser facilmente descrito. Porisso, precisamos de novas ferramentas e técnicas para capturar esta complexidade e para desenvolver uma compreensão mais detalhada de sua profundidade".

Isto significa que o designer de um sistema computacional, olhando para o ambiente de trabalho de fora, não pode esperar apreender os mesmos significados que uma pessoa envolvida nas atividades do dia-a-dia. Da mesma forma, os designers não devem esperar que um usuário possa participar automaticamente das atividades de design, que 
podem ser completamente novas para ele. Portanto, já que tanto os designers quanto os usuários não conseguem compreender totalmente as práticas e significados de cada um, é necessário que se construa uma ponte que aproxime as experiências de cada grupo.

As idéias subjacentes à possibilidade de se construir a ponte baseiam-se na ação cooperativa e não nas descrições formais. Esta ação envolve:

- o aprendizado mútuo entre usuários e designers sobre os seus respectivos campos de atuação;

- a utilização de ferramentas durante o processo de design que sejam familiares aos usuários;

- a previsão das situações de uso futuras, para permitir aos próprios usuários a experiência de como o sistema que está surgindo pođe afetar sua prática de trabalho, ao invés de confiar apenas em uma linguagem aparentemente esotérica da equipe de desenvolvimento;

- a importância de se iniciar o processo de design pela prática dos usuários.

A questão da cooperação ou do respeito pelas competências mútuas é, portanto, central para as idéias da abordagem escandinava.

\section{O que está errado?}

Em um de seus muitos livros sobre desenvolvimento de sistemas, Edward Yourdon - citado em [72] — define sua estratégia para o design como uma que busca "quebrar grandes e complexos problemas em pequenos problemas menos complexos e então decompõe cada um destes problemas menores em problemas ainda menores, até que o problema original possa ser expresso como uma combinação de muitos pequenos problemas solucionáveis".

É claro que a prática cotidiana que envolve um sistema computacional é muito diferente da metodologia formal que os designers tradicionais, como Yourdon, defendem. No entanto, esta maneira de pensar o desenvolvimento de um sistema está muito enraizada na cultura ocidental, o que se reflete na forma de fazer perguntas e no tipo de perguntas que são feitas (veja a discussão sobre estas questões no Capítulo 3). Greenbaum \& Kyng acreditam que "estas tradiçð̃es racionalistas nos impediram de ampliar nossos horizontes e de levantar novas questões sobre o processo de design. Não esperamos que o leitor, e mesmo nós, ignore suas crenças e simplesmente descarte a atual metodologia, mas sim mostrar que, olhando para as premissas por detrás da tradição racionalista, podemos compreender melhor como fomos cerceados e limitados em nosso pensamento - limites que podem parecer erros em nossa prática, mas são, de fato, parte de nossa visão racionalista do mundo e de nossa concepção de sistemas".

Russell Ackoff, em 1974, já chamava a atenção para o problema (citado em [72]): "falhamos muitas vezes porque resolvemos o problema errado e não porque encontramos a solução errada para o problema certo... Os problemas que selecionamos para resolver e a maneira como os formulamos dependem muito mais de nossa filosofia e visão de mundo do que de nossa ciência e tecnologia" (veja Capítulos 1 e 2). A lembrança da importância de uma visão de mundo sugere que a seleção de problemas dentro de um ambiente de trabalho está intimamente associada a valores culturais, políticos e económicos. Não é possível, tanto para usuários quanto para designers, esquecer o passado, 
as tradições e as premissas de cada um. Desta forma, por não ignorar estas questões, a abordagem escandinava busca "fazer novas perguntas e procurar por soluçס̃es para outros problemas" [72].

\section{Ponto de partida}

Um ponto de partida para as idéias e teorias da abordagem escandinava está baseado nos projetos com a participação e/ou iniciativa dos sindicatos ${ }^{4}$. A influência dos empregados através dos sindicatos e a colaboração com os administradores é uma das partes bem conhecidas da prática de democracia social nos paŕses escandinavos. No início dos anos 70, quando uma nova legislação aumentou as possibilidades de influência dos empregadores, esta estratégia, chamada de co-determinação, foi complementada com uma série de projetos iniciados de maneira independente pelos sindicatos locais e nacionais. Nestes projetos, os trabalhadores, auxiliados por consultores e pesquisadores, procuraram desenvolver uma plataforma mais coerente para a influência dos trabalhadores na escolha de novas tecnologias para 0 ambiente de trabalho. Novas práticas de trabalho, baseadas em grupos de trabalho e no desenvolvimento de recursos locais para ação, foram formuladas, tentadas na prática, e reformuladas durante estes projetos. Alguns dos grupos de trabalho produziram critérios para a construção de melhores ambientes de trabalho e sugestôes para sistemas de suporte para grupos de trabalhadores planejando seu própriotrabalho. Como consequêencia destes primeiros projetos, foram acrescentados à legislação existente acordos que permitiram a participação direta dos trabalhadores no desenvolvimento e uso da tecnologia em seus locais de trabalho. Isto levou a uma série de programas de educação nos sindicatos.

Mas, apesar de introduzir a noção de participação do trabalhador nas decisões sobre tecnologia, estes primeiros projetos passaram por uma série de problemas. Do ponto de vista dos sindicatos, aspectos importantes como oportunidade para desenvolver habilidades aprendidas e aumento de influência na organização do trabalho ficaram limitados. Constrangimentos sociais, principalmente no que se refere a poder e recursos, foram subestimados. Além disso, a tecnologia existente não fornecia meios para a busca de soluções alternativas. Isto significava, de fato, que o balanço de poder não foi alterado apesar da legislação.

No início dos anos 80, surgiu a segunda geração de projetos de design. Estes projetos se apoiavam no uso da qualificação como uma forma de aproximar o design de sistemas das perspectivas dos usuários. Esta geração tomou a questão da desumanização do trabalho - ocasionada pela divisão do trabalho e pela desqualificaçãodostrabalhadores (veja [58]) - como o problema central para odesign e o uso de sistemas computacionais.

Nesta busca para fazer da qualificação um aspecto central do design de sistemas, os organizadores dos projetos encontraram dificuldades ao tentar aplicar as ferramentas e técnicas utilizadas tradicionalmente no desenvolvimento de sistemas. A maior dificuldađe foi a limitação inerente às ferramentas e técnicas no que se refere a permitir que os usuários expressassem suas idéias sobre qualificação. Em particular, os projetos indicaram que a noção de habilidade tácita - aquelas que são essenciais para o dia-a-dia, mas que não são facilmente explicadas (veja [184]) - representava um grande impecilho para os designers, que utilizavam representações formais para alimentar o sistema.

4. Veja nota anterior. 
De uma maneira geral, as teorias desenvolvidas podem ser agrupadas sob a denominação de construção social, que vê a compreensão do mundo pelas pessoas como sendo gerada pelas próprias pessoas (através de suas interações sociais), ao invés de um conjunto de fatos fixos e imutáveis 5 .

\section{"O que aprendemos?"}

Greenbaum \& Kyng apresentam um sumário da abordagem escandinava desenvolvido a partir da experiência de vários pesquisadores envolvidos na tentativa de aplicar as idéias e os conceitos de design já mencionados:

- O processo de design precisa ser iniciado com uma compreensão da situação de uso. O desenvolvimento tradicional de sistemas advoga o início do estudo pela identificação "d'O Problema", já que problemas fora do contexto não têm significado. Esta é a razão pela qual os pesquisadores escandinavos acreditam que, examinando o contexto edando atenção às situações nas quais o computador é usado, este pode ser um bom ponto de partida para o design de um sistema. Para que isto seja eficiente, designers e usuários irão se encontrar em caminhos nunca percorridos conforme tentarem aprender as premissas básicas uns dos outros.

- Quando os computadores são introduzidos em uma organização, eles modificam esta organização. Isto se deve ao fato de que os computadores não são entidades estáticas, mas sistemas que se adaptam conforme são usados. Este processo dinâmico de mudanças futuras implica na procura, por parte dos designers, de uma melhor compreensão da organização, e da realização do design pensando nestas mudanças. No passado, modificações no trabalho foram vistas como "consequiencias inesperadas" de um novo sistema computacional. Os pesquisadores escandinavos não acreditam nisso: eles esperam, pelo menos, não ser "surpreendidos" tão facilmente.

- O processo de design está firmemente baseado na experiência, não apenas em regras. A maior parte das metodologias de desenvolvimento de sistemas recomenda procedimentos passo-a-passo para o design e implementação de sistemas computacionais. A abordagem escandinava não acredita que estas metodologias devam ser simplesmente jogadas fora, preferindo achar que, baseando-se mais na experiência de designers e usuários, isto pode levar a sistemas que estejam mais adequados aos usuários envolvidos no projeto.

- Os usuários são profissionais competentes. Com isto em mente, o design deve ser feito pensando-se na qualificação, conhecimento, problemas e medos dos usuários. Ao invés de planejar sistemas "à prova de idiotas", a prioridade deve ser a qualidade e a habilidade no trabalho. Sem dúvida que nem todos os usuários (nem os designers) possuem a mesma qualificação, mas esta diversidade está entre o que pode ser mais cuidadosamente aprendido quando existe reflexão sobre a prática de trabalho.

É possível apresentar, por fim, um contraste das maiores diferenças entre a abordagem tradicional e a escandinava. Veja o Quadro 4.1. 


\begin{tabular}{l} 
Abordagem tradicional \\
\hline - problemas \\
- fluxo de informação \\
- tarefas \\
- habilidades que podem ser descritas \\
- regras dos especialistas \\
- procedividuos \\
\hline
\end{tabular}

- problemas

- fluxo de informação

- tarefas

hablidades que podem ser descritas

- individuos

- procedimentos baseados em regras

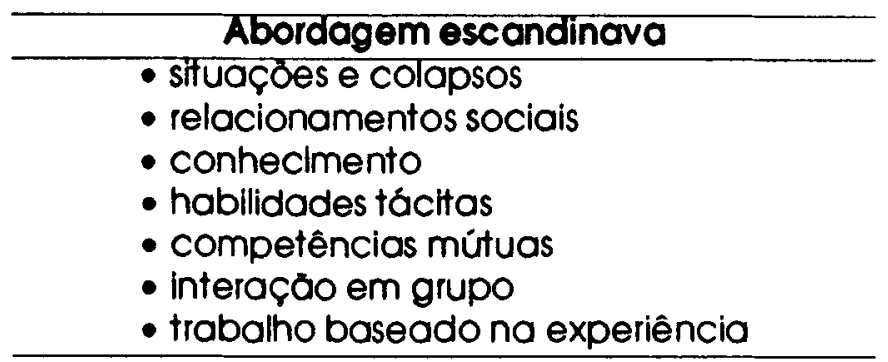

\section{Novas bases para o design}

As conclusões formuladas nas seções anteriores baseiam-se em conceitos criados por pesquisadores de diversas área do conhecimento. Estes conceitos fornecem uma sólida base em Ciências Humanase serviram de inspiração para o desenvolvimento de uma abordagem que leva em consideração as questões apresentadas neste capítulo. Os principais conceitos são apresentados a seguir:

Hermenêutica. A hermenêutica surgiu como uma teoria sobre a interpretação de textos, especialmente de textos místicos e sacros. Seus praticantes se debateram com o problema de caracterizar como as pessoas mantém o mesmo sentido de um texto durante muitos séculos, mas que é compreendido diferentemente a cada época. Um texto religioso, por exemplo, continua a ser lido e a servir como uma fonte de significados, apesar das mudanças na cultura subjacente e mesmo na propria linguagem. Nesta situação, existem algumas questð̃es 6 bvias. Será que o significado de um texto pode ser definido em algum sentido absoluto, independente do contex to no qual foi escrito? Ou só pode ser definido em termos do contexto original? Se isto é verdade, é possível ou desejável para o leitor transcender a sua própria cultura e a intervenção da história, de maneira a recuperar a interpretação correta?

Se a noção de que o significado está no texto for rejeitada, será que se fica restrito a apenas dizer que uma pessoa em particular em um momento particular fez uma interpretação particular? Se isto é assim, será que não se está trocando uma visão da realidade aparentemente sólida, mas ingênua, por um aspecto relativístico de uma reação subjetiva individual?

Dentro da área de estudo da hermenêutica existe um grande debate entre aqueles que colocam o significado dentro do texto e aqueles que veêm o significado como apoiado por um processo de compreensão no qual o texto, sua produção, e sua interpretação compóem cada um parte vital do conjunto. Existe um debate semelhante na pesquisa atual em lingüística e teoria semântica.

Para a escola objetivista da hermenêutica, o texto deve possuir um significado que existe independentemente de qualquer ato de interpretação. Seu objetivo é o de desenvolver métodos para que as pessoas possam deixar seus preconceitos de lado e produzir uma análise objetiva do que realmente está no texto. O ideal e "descontextualizar" completamente o texto.

A abordagem oposta - formulada principalmente pelo filósofo Hans Georg Gadamer (citado em [225]) - considera o ato de interpretação como sendo algo primordial, compreendendo-o como uma interação entre o horizonte (ou ponto de vista) fornecido pelo texto e o horizonte que o interpretador traz para o texto. Para Gadamer, cada leitura de um texto constitui um ato de dar significado através de uma interpretação.

Segundo Gadamer, qualquer individuo, ao tentar compreender seu mundo, está se envolvendo continuamente em atividades de interpretação. Esta interpretação está baseada em preconceitos (ou pré-conhecimento), o que inclui pressuposições implícitas na linguagem que a pessoa utiliza. Esta linguagem, por sua vez, é aprendida através de
Quadro 4.1

Diferenças entre as abordagens tradicinal e escandinava. 
atividades de interpretação. O individuo se modifica através do uso da linguagem e a linguagem é modificada pelo uso feito pelos indivíduos. Este processo é de importância fundamental, já que constitui o repertório de crenças e pressuposiçőes que determinam a natureza do ser humano. As pessoas sãoc criaturas sociais que, em associação com a historicidade de cada indivíduo - definida por Gadamer como uma realidade histórica de cada pessoa percebida através da compreensão da família, da sociedade e do estado em que ela vive -, perdem a habilidade de encontrar uma compreensão completa e explícita de si próprios. A natureza humana está determinada por seu repertório cultural e, já que este repertórioé formado pela maneira de experimentar e vivenciar através da linguagem, ele não pode ser explicitado completamente nesta mesma linguagem.

A abordagem de Gadamer aceita a inevitabilidade do que é conhecido como "círculo hermenêutico": o significado de um texto individual é contextual, dependendo do momento da interpretação e do horizonte adotado pelo interpretador. Mas este horizonte $e$, por sua vez, produto de uma história de interações via linguagem, interaçóes as quais representam textos que devem ser compreendidos à luz dos pré-conhecimentos de cada pessoa. Para Gadamer, "o que os seres humanos compreendem está baseado naquilo que já conhecem, e aquilo que já conhecem depende de sua capacidade de compreender" [225].

Compreensão e ontologia. Gadamer - e antes dele o filosofo Martin Heidegger - estendeu o conceito hermenêutico da interpetação para além do domínio da análise textual, colocando-o junto aos fundamentos da cognição humana. Da mesma forma que se pode perguntar qual o papel da interpretação na interação de uma pessoa com um texto, é possível examinar seu papel na compreensão do mundo como um todo.

Gadamer e Heidegger rejeitam a filosofia de senso comum da cultura ocidental de uma forma profunda e fundamental. O ponto de vista que prevalece está baseado na revolução metafísica de Galileu e Descartes, que surgiu a partir de uma tradição oriunda de Platãoe Aristóteles. Esta compreensão, que anda de mãos dadas com o que é chamado de "orientação racionalista", inclui um tipo de dualismo mente-corpo que aceita a existência de dois domínios separados de fenômenos: o mundo objetivo da realidade física, e o mundo mental subjetivo dos pensamentos e sensações de um indivíduo. De maneira resumida, esta visão foi apresentada no Capítulo 3.

Heidegger rejeita tanto esta instância objetiva ("o mundo físico objetivo é a realidade básica"), quantouma instância simplista subjetiva ("meus pensamentose sensações são a realidade básica"), argumentando que, na verdade, uma não pode existir sem a outra. $O$ que está sendo interpretado e o interpretador não existem independentemente: existência é interpretação, e interpretação é existência. Preconceitos não formam a condição na qual um indivíduo é levado a interpretar falsamente o mundo, mas sim a condição necessária para possuir um repertório que permita interpretar (dar existir como ser humano).

Quatro pontos são relevantes para a argumentação de Heidegger [225]:

-Ascrenças epressuposições humanasnãopodem ser explicitadas totalmente. Não existe um ponto de vista neutro a partir do qual é possível ver as crenças como coisas, já que os seres humanos sempre operam a partir do quadro de referências que estas crenças fornecem. Esta é a idéia básica do círculo hermenêutico, aplicado à compreensão como um todo. 
- A compreensão prática é mais fundamental do que a compreensão teórica. As pessoas têm acesso ao mundo através de um envolvimento prático - no mundo sobre o qual agem irrefletidamente. A contemplação à distância pode ser iluminadora, mas também obscurece os próprios fenômenos ao isolá-los e categorizá-los. A maior parte da pesquisa atual sobre lógica, linguagem e pensamento, está preocupada com a primazia das atividades relacionadas à contemplação à distância. Heidegger não ignora este tipo de pensamento, mas o coloca no contexto de cognição como práxis - como atuação consciente sobre o mundo. Ele está preocupado com a condição humana de throwness (ser arremessado, atirado, jogado em) - a condição de compreensão na qual as ações humanas encontram alguma ressonância ou eficácia no mundo.

- As pessoas não se relacionam com as coisas através das representações que têm delas. Em conexão com os dois pontos precedentes está a rejeição de Heidegger ds representaçðes mentais. O senso comum adotado pela tradição ocidental diz que, para perceber e se relacionar com as coisas, é necessário que a mente humana tenha algum tipo de conteúdo que corresponda ao conhecimento que tem das coisas. Ao martelar um prego (em oposição a pensar sobre o martelo), nãoé preciso fazer uso de qualquer representação explícita do martelo. A habilidade para agir vem da familiaridade com o martelar, e não do conhecimento sobre um martelo. Este ceticismo com relação a representações mentais está em forte desacordo com as abordagens atuais em psicologia cognitiva, lingüística, inteligência artificial, e os fundamentos da ciência cognitiva.

- O significado é fundamentalmente social e não pode ser reduzido da atividade de atribuir-sentido executada por indivíduos. A tradição racionalista para a cognição está centrada no indivíduo. Heidegger argumenta que esta é uma abordagem incorreta - deve-se considerar a atividade social como a fundamentação básica da inteligência, e mesmo da existência. Uma pessoa não é um indivíduo ou ego, mas uma manifestação do ser-no-mundo (" $\mathrm{Da}$ sein") dentro de um espaço de possibilidades, situado dentro de um mundo e de uma tradição.

Throwness. Quando uma pessoae "arremessada", “atirada", ou "jogada" em uma situação, ela se encontra em uma condição de throwness, que pode ser caracterizada como [225]:

- Uma pessoa não pode evitar a ação. Ela e “jogada" em uma ação independentemente de sua vontade.

- Umapessoa nãopode voltar atráse refletir sobre suas ações. Ao tentar responder imediatamente ao que outras pessoas estão dizendo ou fazendo, é impossível analisar a situação explicitamente e, assim, escolher a melhor forma de agir.

- Os efeitos de uma ação não podem ser previstos. Mesmo que uma pessoa tenha tempo para refletir, é impossivel saber como suas ações vão afetar outras pessoas. É claro que isto não implica que o mundo é totalmente caótico, 
mas simplesmente que não se pode contar com um planejamento racional e cuidadoso para encontrar os passos que permitam alcançar os objetivos estabelecidos.

- Uma pessoa não tem uma representação estável de uma situação. Somente após a situação ter ocorrido, pode-se reconhecer os padrões significativos. - Qualquer representação é uma interpretação. Mesmo após a situação ter ocorrido, a descrição do que aconteceu dificilmente é uma análise objetiva do tipo que pode ser sujeita a uma prova.

- Linguagem é ação. Cada vez que uma pessoa fala ela está fazendo algo bem diferente do que simplesmente "estabelecendo um fato". Seja uma caracterização levada em consideração como ponto paćficico ou como base para argumentação, a pessoa criou os objetos e suas propriedades ao fazer as afirmações.

Colapsoe "estar-na-mão". Outro conceito importante derivado do trabalho de Heidegger - o de que os objetos e suas propriedades não são inerentes ao mundo, mas surgem apenas quando ocorre um colapso no qual eles se tornam evidentes. Um exemplo simples fornecido por Heidegger é o do martelo. Para quem está martelando, o martelo não existe como martelo. Ele é parte de um background de estar-na-mäo, considerado como ponto paćficico sem um reconhecimento ou identificação explícito de que é um objeto. Ele é parte do mundo de quem martela, mas não está mais presente do que os tendões do braço de quem martela.

O martelo só se apresenta como martelo quando existe algum tipo de avaria ou interrupção. $O$ fato de ser martelo surge quando ele quebra ou tira uma lasca da madeira ou entorta o prego, ou se existe o prego mas não se acha o martelo. Como observadores, pode-se falar sobre o martelo e refletir sobre suas propriedades, mas para uma pessoa imersa no ato de martelar, o martelo não existe como uma entidade.

Durante o uso de sistemas computacionais ocorre uma situação semelhante: para diferentes pessoas envolvidas em diferentes atividades, a existência de objetos e suas propriedades emergem em diferentes tipos de quebras ou interrupçôes. Ou seja, não existe sentido em falar sobre a existência de objetos e suas propriedades na ausência de uma atividade envolvente, com todo o seu potencial para panes, avarias ou colapsos. $O$ que realmente é não é definido por um observador onisciente, nem por um indivíduo, mas sim por um espaço de potencialidades para ação e preocupação humanas.

Autopoiesis. Um sistema autopoiético - conceito desenvolvido pelo neurofisiologista Humberto Maturana - pode ser caracterizado como "a organização do viver através de uma rede de processos de produção (transformação e destruição) de componentes que: (1) através de suas interações e transformações regeneram continuamente a rede de processos (relaçð̃es) que os produzem; e (2) formam uma unidade concreta no espaço no qual eles (os componentes) existem pela especificação do domínio topológico de sua realização como rede" [146].

À primeira vista, esta definição pode parecer irrelevante ou trivial. Mas, na verdade, é uma afirmação ampliada e cuidadosamente lapidada de uma idéia muito simples: a característica essencial de um sistema vivo é que ele é uma coleção de componentes que constitui uma unidade que pode viver ou morrer. $O$ mecanismo pelo qual um or- 
ganismo vem a funcionar adequadamente em seu ambiente é um mecanismo de seleção, o que inclui tanto a seleção de mudanças estruturais dentro de um indivíduo quanto a seleção de indivíduos pelas possibilidades de sobrevivência e desintegração. Um sistema plástico, determinado pela sua estrutura (isto é, um sistema cuja estrutura se modifica durante o tempo enquanto sua identidade permanece constante), que seja autopoiético deverá, por necessidade, evoluir de maneira a que suas atividades estejam acopladas ao seu ambiente. Sua estrutura precisa se modificar de maneira a gerar as mudanças de estado apropriadas, disparadas por mudanças perturbadoras específicas no ambiente; de outra forma, ele (o sistema) se desintegra.

Neste sentido, Maturana \& Varela oferecem uma definição para "aprender": "Aprender não é um processo de acumulação de representações de um ambiente; aprender é um processo contínuo de transformação de comportamento através da mudança constante da capacidade do sistema nervoso de sintetizar estas mudanças"[146], que, se associada ao conceito de acoplamento estrutural, constitui "a base não só para as mudanças em um indi víduo durante sua vida (aprender) mas também para as mudanças que ocorrem através de reproduções (evolução). De fato, toda mudança estrutural pode ser vista como ontogenética (ocorrendo durante a vida de um indíviduo). Uma mutação genética é uma mudança estrutural para os pais que não tem um efeito direto em seu estado de autopoiesis até que tenha um papel no desenvolvimento de uma descendência" [146], faz o papel que atribuímos ingenuamente a uma representação do mundo. Como resultado deste acoplamento, a estrutura do sistema nervoso gera padrões de atividade que são disparados por perturbações específicas e que contribuem para a conti nuação da autopoiesis de um indivíduo.

A preocupação primária de Maturana é a de entender o que "cognição" pode significar quando relacionada com a natureza fundamental dos sistemas vivos. Rejeitando a metáfora de processamento de informação como base para a cognição, ele substitui a questão "Como um organismo obtém informação sobre o ambiente?" por "Como acontece de um organismo ter a estrutura que permite que ele opere adequadamente em um meio no qual existe?" [146]. Uma resposta para esta questão não pode ser gerada pela compreensão de como opera um sistema nervoso, mas precisa estar apoiada em uma profunda compreensão de como a atividade cognitiva é comum a toda forma de vida, e é determinada pelo fenômeno subjacente da autopoiesis. Como observa Maturana, "sistemas vivos são sistemas cognitivos, e viver, como um processo, é um processo de aprendizado. Esta afirmação é válida pra todos os organismos, com e sem um sistema nervoso".

Artefatos. Artefatos são, segundo o dicionário, objetos feitos pelo homem através de seu trabalho. Ehn chama a atenção para a posição marxista de que os artefatos não refletem apenas as relações sociais, mas são relações sociais; e para a posição de Heidegger, na qual o uso do artefato deve ser visto como fundamental para a existência humana [58]. Para Ehn, deliberadamente ou não, as pessoas, ao criarem artefatos, também criam as condiçðes para seu uso. Desta forma, ao fazer o design de um artefato, deve-se incluir e antecipar a situação dos usuários e sua compreensão do artefato.

Entendidos a partir de seu uso, os artefatos possuem algumas características que devem ser estudadas (e que serão detalhadas no Capítulo 5): 
- Os artefatos servem de suporte para atividades comunicativase instrumentais. Eles podem intermediar a atividade humana em relação a outros seres humanos e objetos.

- A linguagem e o trabalho são dois aspectos que podem ser apoiados pelas atividades comunicativas e instrumentais com o objetivo de aprimorar um produto.

- Um artefato pode expandir ou substituir a atividade humana. $O$ fato de ocorrer uma ou outra situação está relacionado com a habilidade e a competência do usuário.

Ação situada. O conceito de ação situada foi proposto por Suchman [214-215] — para designar a alternativa para a compreensão dos modelos de ação e compreensão mútua sugerida pela etnometodologia ${ }^{6}$. O termo destaca a visão de que qualquer ação depende, de forma essencial, das circunstâncias materiais e sociais de sua ocorrência. Em vez de afastar a ação de suas circunstâncias e de representá-la através de um plano - como geralmente é proposto pelos modelos cientıficos da ação - Suchman propóe que se estude como as pessoas usam estas circunstâncias para agir inteligentemente. Em vez de construir uma teoria da ação a partir de uma teoria de planos, o objetivo de sua pesquisa foi o de investigar como as pessoas produzem planos no decorrer da ação.

A abordagem etnometodológica para a ação e a compreensão mútua pode ser resumida em cinco proposiçøes:

- Os planos são representaçס̃es de ações situadas.

- No decorrer de uma ação, pode surgir uma representação quando a atividade anteriormente transparente se transforma em algo problemático.

- A objetividade das situaçães de uma dada ação são alcançadas e não fornecidas a priori.

- Uma importante fonte para alcançar a objetividade das situaçõesé a linguagem, que geralmente está relacionada - de forma indexada, no sentido proposto por Charles Peirce - com as circunstâncias que ela pressupõem, produz e descreve.

- Como consequência desta indexabilidade da linguagem, a compreensão mútua pode ser alcançada em cada ocasião onde ocorre interação com referências a particularidades de uma situação, em vez de ser descartada completamente por um corpo estável de significados partilhados.

No Capítulo 5 será apresentada uma aplicação que é, ao mesmo tempo, uma exten-

6. Veja o número especlal da revista Cognitive Science editado por Donald A. Norman dedicado a este tema: (42). (171) $\theta(2 \mid 4)$. 


\section{A interface com o usuário é onde está a ação}

$O$ "desaparecimento" da imagem humana nos desenhose pinturas de Picasso, revela muito sobre como a cultura vai se alterando gradativamente.

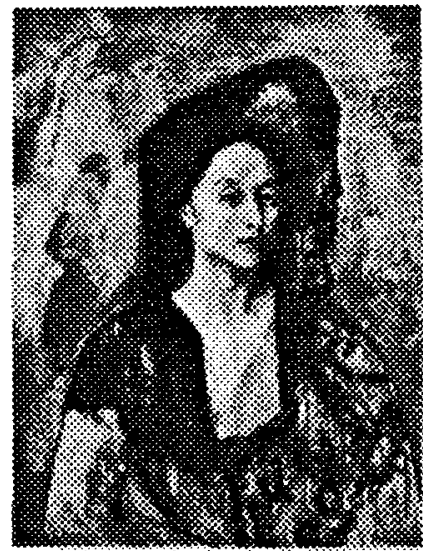

Retralo da Señora Canals (1901).
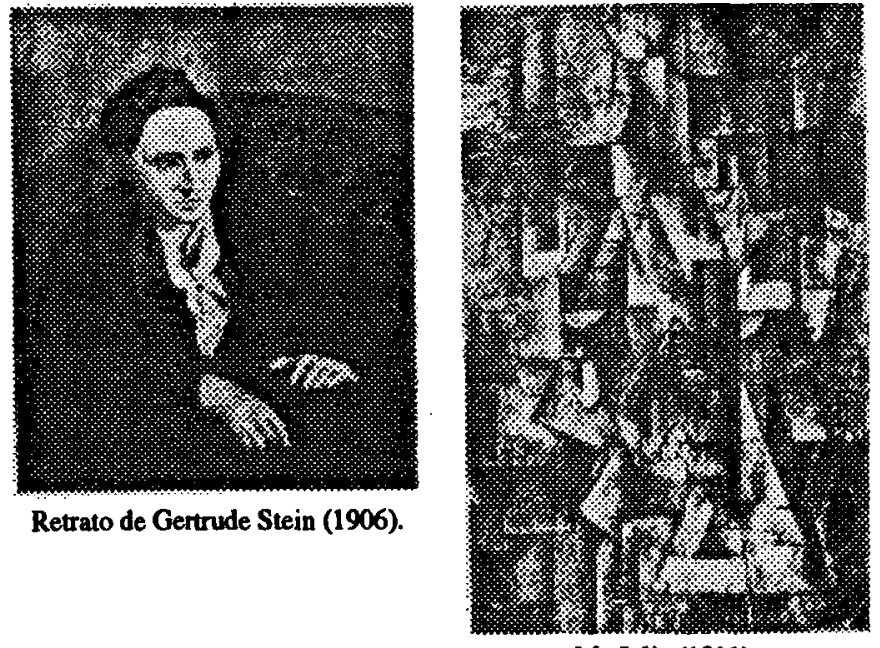

Ma Jolie (1911). 
"É idéia básica deste livro que, por razóes epistemológicas, a participação é necessária para aprimorar a qualidade do processo de design assim como da aplicação, especialmente no que se refere dinterface como usuário. (...) Eu advogo uma democratização do design. A participação no design não corresponde, por si só, a um design democrático, é apenas um possivel passo nesta direção. Investigações associadas aos sindicatos, acordos tecnológicos, e vários sistemas de negociação são parte dos mecanismos necessários para se alcançar a democracia. De acordo com esta visão, precisamos ver o design como uma atividade que é um processo de negociação entre diferentes grupos com interesses conflitantes e com diferentes recursos e poder para atingir seus objetivos."

Susanne Bødker, Through the Interface: A Human Activity Approach to User Interface Design, p. 4.

A própria escolha de se usar o termo design e não o termo mais comum desenvolvimento, é um exemplo das possibilidades de se enxergar certos aspectos da tecnologia, enquanto cria uma espécie de "cegueira" em relação a outros: ao utilizar design, o desejo - como Bødker - é salientar as similaridades entre as questões da área de computação com outros tipos de design - como a arquitetura onde se busca normas para qualidade exatamente como em outras profissães. Ao mesmo tempo, escolher não usar o termo desenvolvimento significa uma atenção menos direta no papel queo design de aplicaçóes tem no processo de desenvolvimento organizacional.

Em design, a interface com o usuário é um aspecto da futura aplicação; a interface com o usuário é um objeto para o design. Durante o uso, no entanto, a interface determina como a aplicação se apresenta ao usuário. Para compreender a interface com o usuário, é preciso estudar a relação de uso entre o ser humano e a aplicação. O estudo desta relaçẫo tem sido uma questão de pesquisa para a psicologia, a antropologia, e a filosofia (veja, por exemplo, [132] e [147-148]).

Em Through the Interface Susanne Bødker explora as possibilidades de oferecer uma nova concepção de interface com o usuário [33]. Ela apresenta um quadro de referência que se apóia na teoria antropológica/psicológica de A. N. Leontjev, cujo trabalho apresenta explicações quase operacionais e detalhadas sobre o que os seres humanos fazem quando manipulam artefatos. Para Bødker, "lidar com a atividade de trabalho do ser humano significa lidar com o que é especificamente humano, se comparado com objetos ou animais, a habilidade especifica de criar artefatos pensando no seu uso futuro. Apenas os seres humanos conduzem um design imaginando o uso futuro do artefato. $O s$ seres humanos não conduzem um design como um processo bem planejado onde primeiro se determinam os objetivos e em seguida as ações. Pelo contrário, iniciamos um design como um processo onde modificamos nossas ações conforme interagimos com o mundo material".

Como é necessário uma compreensão prática para se fazer uso da compreensão teórica, novas sugestôes de métodos para o design e para a interface com o usuário devem seguir estas considerações teóricas. Além disso, os novos métodos de design e as novas interfaces devem nascer de uma situação específica de design que, por sua vez, deve estar direcionada, como foi visto no Capítulo 4, para as futuras situações de uso. 
Isto significa, como salienta Bødker, que "não posso esperar fornecer novos guidelines gerais para a interface com o usuário e seu design, nem posso sentar em minha mesa e construir exemplos, sem testar realmente a teoria em situaçð̃es práticas de design".

\section{Background teórico}

A intenção do trabalho de Bødker é a de facilitar o design de melhores interfaces com o usuário, o que significa "começar e terminar com o que são computadores e aplicativos computacionais, e como eles podem ser construídos para funcionar o mais eficientemente possível". Para ter acesso a este tipo de eficiência, entretanto, são precisos métodos diferentes daquelesusados para se obter, por exemplo, eficiência dos algoritmos. A teoria dos algoritmos e de sua eficiência se desenvolveu apoiada na Matemática. No entanto, para Bødker, "para lidar com a eficiência da interface com o usuário, precisamos lidar não apenas com o computador, mas também com a interação entre os seres humanos e os computadores".

O impacto filosófico de pesquisas como a de Winograd \& Flores [225], de Suchman [215] e de Dreyfus \& Dreyfus (H. Dreyfus \& S. Dreyfus, Mind Over Machine: The Power of Human Intuition and Expertise in the Era of the Computer, Basil Blackwell, Glasgow, 1986, citado em [225]) gerou uma nova abordagem terrica que considera a atividade humana - incluindo o designe o uso de aplicativos computacionais - como não sendo caracterizada basicamente por racionalidade, planejamento e reflexão, mas pela prática epela habilidade das pessoas de agir em situaçőes. Bødker observa que, apesar de Heidegger, Wittgestein, Polanyi, Vygotsky e Leontjev terem desenvolvido suas teorias na Filosofia ou na Psicologia, o objetivo dos trabalhos de Winograd \& Flores, Suchman, Dreyfus \& Dreyfus, Ehn e outros foi o de criar novos fundamentos para o design de aplicativos computacionais e para a compreensão do papel do computadores na vida das pessoas, em atividades humanas gerais ou específicas como o trabalho.

Bødker apresenta duas razőes para adotar a abordagem do psicólogo soviético: (i) apesar de todas as teorias partilharem a idéia fundamental de que a prática é a base do existir e do fazer dos seres humanos, elas se diferenciam na maneira de considerar a linguagem - para Winograd \& Flores, toda atividade é basicamente comunicação, "resultando em uma visão de que a prática existe para cada ser humano individualmente"; para Dreyfus \& Dreyfus, o problema está no aprendizado e na competência dos indivíduos, sem associar a "competência às condiçôes materiais, nem que estes artefatos são usados em alguma atividade, carregam uma certa prática, e que a competência é algo social"; Leontjev considera a prática em relação tanto às condições materiais partilhadas pelo grupo de seres humanos quanto à consciência de cada indivíduo; (ii) a abordagem utilizada, por exemplo, por Winograd \& Floresé a de juntar pedaços de diferentes teorias com diferentes tradiçóes, sugerindo que "[estes pedaços] podem ser aplicados em conjunto e năo geram conflitos de pressuposiçőes" [33].

O tema da pesquisa de Bødker está centrado em aplicações computacionais, ou artefatos computacionais. Estes artefatos, segundo Bødker, são empregados pelos usuários em atividades de criação de algum produto ou para alcançar algum objetivo. Por um lado, a atividade de uso e o produto pretendido são parte da determinação de como o artefato deve ser empregado. Por outro, a construção real do artefatoé parte da determinação de quais situações de uso e produtos podem ser criados. Relações similares a estas podem ser encontradas entre a atividade de design e 0 artefato computacional, e entre a situação de design e os métodos de design que podem ser usados. 
Bødker avisa, no entanto, que sua pesquisa "de forma alguma encara os métodos de design como algo que possa ser seguido como um computador executando um algoritmo. Pelo contrário, os métodos de design são vistos como algo que pode apontar para várias formas de alterar as práticas de design em situações especúficas".

\section{A atividade humana e a interação homem-computador}

Nos últimos anos o uso de computadores passou do de uma calculadora para uma ampla variedade de aplicações, e o tipo de pessoa que se utiliza de computadores deixou de ser um típico especialista da computação. As diversas perspectivas apresentadas no Capítulo 2 representam tentativas para compreender esta mudança e adaptar odesenvolvimento de sistemas à realidade dos novos problemas esboçados.

$\mathrm{O}$ argumento básico de Bødker é o de que não importa qual abordagem está sendo utilizada para a interação homem-computador, sempre será possível encontrar exemplos que indicam que a perspectiva não é rica o suficiente para cobrir todo tipo de aplicativo. Nem uma perspectiva isolada como "o-usuário-e-sua-ferramenta", nem uma de meio ou decomunicação parece ser suficiente para compreender a interação homem-computador. Bødker conclui que "precisamos de um quadro de referência que dê conta de ambos os usos, de comunicação e de ferramenta, nas situaçôes de trabalho onde os computadores estão envolvidos. Este quadro pode ser criado da seguinte maneira: ao conduzir algum tipo de processo de trabalho, [uma pessoa] faz mais do que apenas interagir com o computador. Ela cria um produto através da ferramenta e se comunica através do meio. A pessoa se comunica com seus colegas de trabalho, seja para aprender sobre as ferramentas, materiais e produtos de uma dada situação problemática, seja para coordenar o esforço comum. A comunicação não acontece isolada da relação com materiais e produtos o significado linguístico se forma a partir de uma atividade de trabalho comum entre pessoas, para contribuir para o objetivo geral do trabalho em si. A interação homemcomputador faz parte de uma atividade de trabalho específica na qual o computador é utilizado".

O principal propósito de Bødker é o de compreender a interação homem-computador, e as condiçóes para que isso ocorra, isto é, a interface com o usuário. A idéia é a de que, de um lado, esta interação não pode ser vista independentemente da situação de uso, e, de outro, a compreensão da interface com o usuário não deve apenas dar atenção as necessidades de um indivíduo isolado em uma situação específica. A proposta da autora e, então, a de "elaborar uma teoria sobre a interação homem-computador como parte de uma teoria do trabalho humano". A abordagem se detém no uso de artefatos computacionais na atividade de trabalho humana e, assim, no papel da interface com o usuário e da interação homem-computador em uma atividade específica de trabalho. Específico para a vida humana, como pode ser visto, é que os seres humanos, ao contrário dos animais ou das coisas, criam artefatos para serem aplicados em uma atividade de uso futura.

\section{A atividade de trabalho humana}

A atividade de um ser humano faz parte de uma atividade coletiva de vários grupos. A atividade individual tem como objetivo (ou é direcionada para) realizar uma determinada tarefa que, por sua vez, contribui para os objetivos da atividade coletiva. 


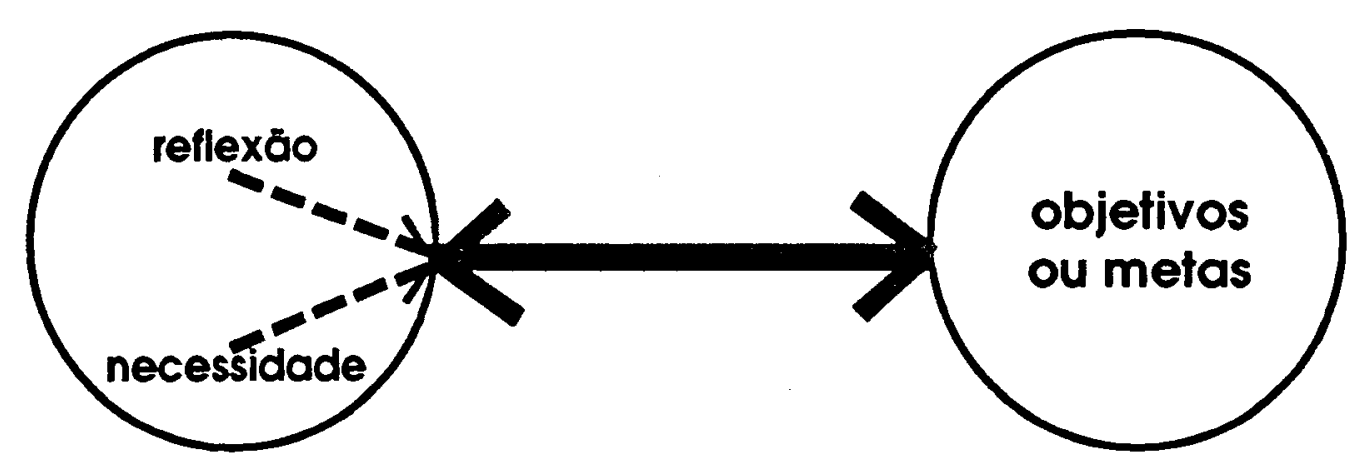

Flgura 5.1

Atividade humana (ct. (33)).
A comunicação tem um papel importante na organização, coordenação e controle da atividade coletiva. Isto significa que uma pessoa direciona partes de sua atividade para outros seres humanos ou sujeitos. Bødker denomina estas partes de aspecto comunicativo da atividade humana, onde, por exemplo, uma pessoa discute com seu chefe como realizar sua tarefa. Outras partes estão direcionadas para objetos, e são denominadas de aspecto instrumental: as atividades especificas para realizar uma tarefa.

Nesta atividade, a pessoa utiliza artefatos. Tanto o aspecto comunicativo quanto o instrumental podem ser intermediados pelos artefatos. Uma ferramenta (como um martelo ou uma faca) faz a intermediação do aspecto instrumental da tarefa. Esquemas, rascunhos, desenhos e planos fazem a intermediação do aspecto comunicativo, visando coordenar a execução da tarefa.

A atividade humana pode ser vista como conduzida através de ações, que ocorrem em uma unidade de tempo e espaço com intenções bem definidas. Uma açãoe executada através de uma ou mais operações, que estão associadas às condições materiais específicas. A exata operação a ser utilizada é acionada pelas condições materiais; ela não é escolhida conscientemente pela pessoa. Além disso, o que em algumas situações são ações, em outras podem ser consideradas como operações que fazem parte de outras ações.

Através da aprendizagem - especialmente em atividades escolares ou em atividades rotineiras de trabalho - as pessoas obtêm um repertório de operações para ser usado em uma atividade específica. As pessoas têm de partilhar uma prática ao mesmo tempo que são parte constituinte desta prática. Isto é chamado de conceitualização. Mudar o nível de ação significa modificar o objeto (ou sujeito) das ações: ao invés de trabalhar a nível mais geral, a pessoa passa a se preocupar com os detalhes. Modificações não previstas nas condições materiais em uma atividade especifica podem causar uma conceitualização. Estas situações são chamadas de breakdowns ou colapsos (veja o capítulo 4).

\section{Sumário da feoria da atividade humana}

Segundo a interpretação dada por Bødker para os principais conceitos e idéias de Leontjev, a atividade de trabalho humana é o componente básico desta teoria. Um ser humano realiza cada ação concreta, através da qual a atividade é completada. As açőes concretas que um ser humano realiza contribuem para uma atividade humana individual: um processo através do qual o ser humano produz algum tipo de relação com o mundo físico e social ao seu redor.

A pessoa visa alcançar um objetivo com a atividade, isto é, visa resolver umatarefa ou problema, equer direcionar sua atividade para algum objeto, algum material que deve ser afetado pela atividade (veja Figura 5.1). Pode-se dizer que toda atividade está associada a um objetivo e/ou um objeto. $O$ que em al gumas situações é uma intenção de uma ação, pode ser uma atividade com propósito proprio em outra, e vice-versa. 


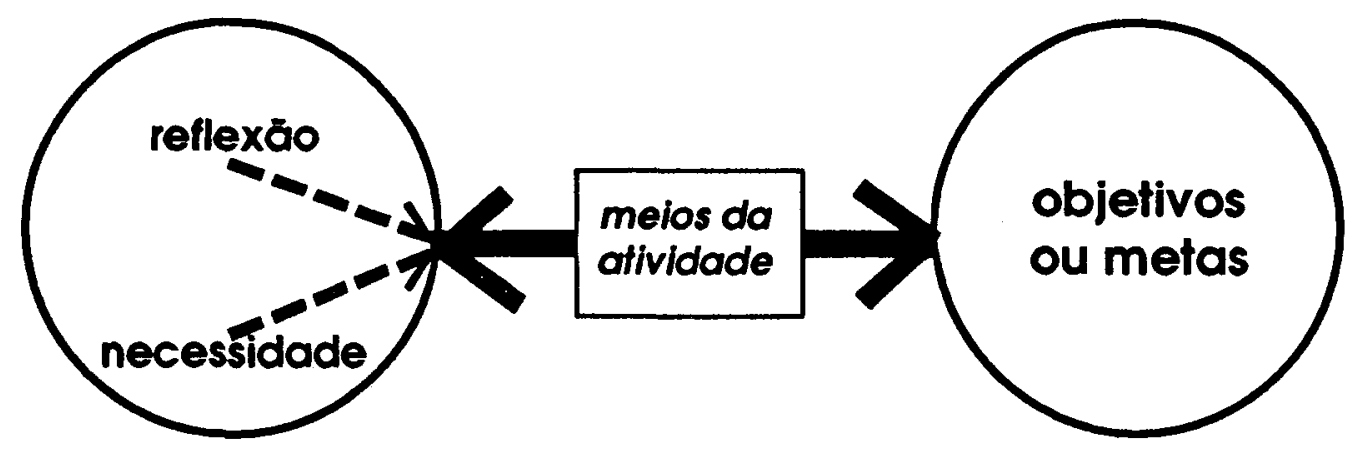

As características do objetivo ou do objeto determinam parcialmente a estrutura da atividade. Se um ser humano lida com um objeto físico, a estrutura física do objeto irá delimitar quais ações podem ser realizadas, como devem ser realizadas, e em qual seqüencia. Se a tarefa, por exemplo, é a de coletar informações de várias fontes físicas e humanas, a estrutura física e social - por onde começar, com quem falar e como falar - irá determinar a estrutura.

A produção das relações entre um ser humano e seu mundo deve proceder da seguinte maneira: por um lado, alguma necessidade irá forçar as ações do sujeito, com certas intenções, as quais intervirăo no mundo físico e social, por exemplo, para alterar um objeto especifico. Esta intervenção está baseada em uma reflexão mental sobre o mundo, incluindo este específico objeto. Por outro lado, como um objeto físico está estruturando as açð̃es do ser humano, a reflexão sobre o objeto está sendo criada e alterada através das ações.

Em uma atividade humana, são utilizados diversos meios: técnicas culturais, como as formas de estruturar as ações individuais; artefatos, como martelos ou telefones; elinguagens. Através destes meios, o ser humano controla sua relação com o mundo (veja Figura 5.2).

Os seres humanos sempre participam de várias atividades. Estas atividades coletivas são estruturadas a partir de uma certa ordem da sociedade na qual as pessoas vivem (veja Figura 5.3). O indivíduo irá encontrar esta ordem através de relaç̃̃es de poder, instituições, e agrupamentos de interesse na sociedade, sob a qual os seres humanos vivem, ao mesmo tempo que podem contribuir para mudanças. Na maior parte das sociedades, a divisão de trabalho causou uma separação entre as necessidades do indivíduo e o objetivo da atividade na qual ele toma parte. Mais do que isso, as necessidades do indivíduo como parte de diferentes atividades coletivas podem ser diferentese mesmo conflitantes. Pode-se dizer que uma pessoa não possui uma necessidade na atividade concreta mas um grupo de necessidades, muitas delas conflitantes.

Em uma atividade coletiva, a linguagem é utilizada para coordenar o trabalho.Cada atividade individual consiste de comunicação com outros seres humanos para organizar, coordenar e controlar a atividade, e de açðes direcionadas para as coisas que servem como objetos ou artefatos em uma produção material. Geralmente, se diz dos aspectos comunicativo e instrumental da atividade humana.

Ações. Cada atividade individual (veja Figura 5.4)é conduzida através de ações, conduzidas em uma unidade de tempo e espaço, com intenções especificas (o quê deve ser feito). É por causa destas intenções, transformadas em ações e atividade, que se pode comunicar $o$ aspecto instrumental de uma atividade - a atividade instrumental possui um significado para a pessoa. Estas açoes são direcionadas conscientemente para um objeto ou sujeito. Cada ação executada por uma pessoa é composta por operações (como é feito). Em uma atividade, as intençð̄es das ações podem não estar relacionadas direta-

Flgura 5.2 Meios $\theta$ atividade humana (cf. (33)). mente com as metas ou objetivos de uma atividade. 


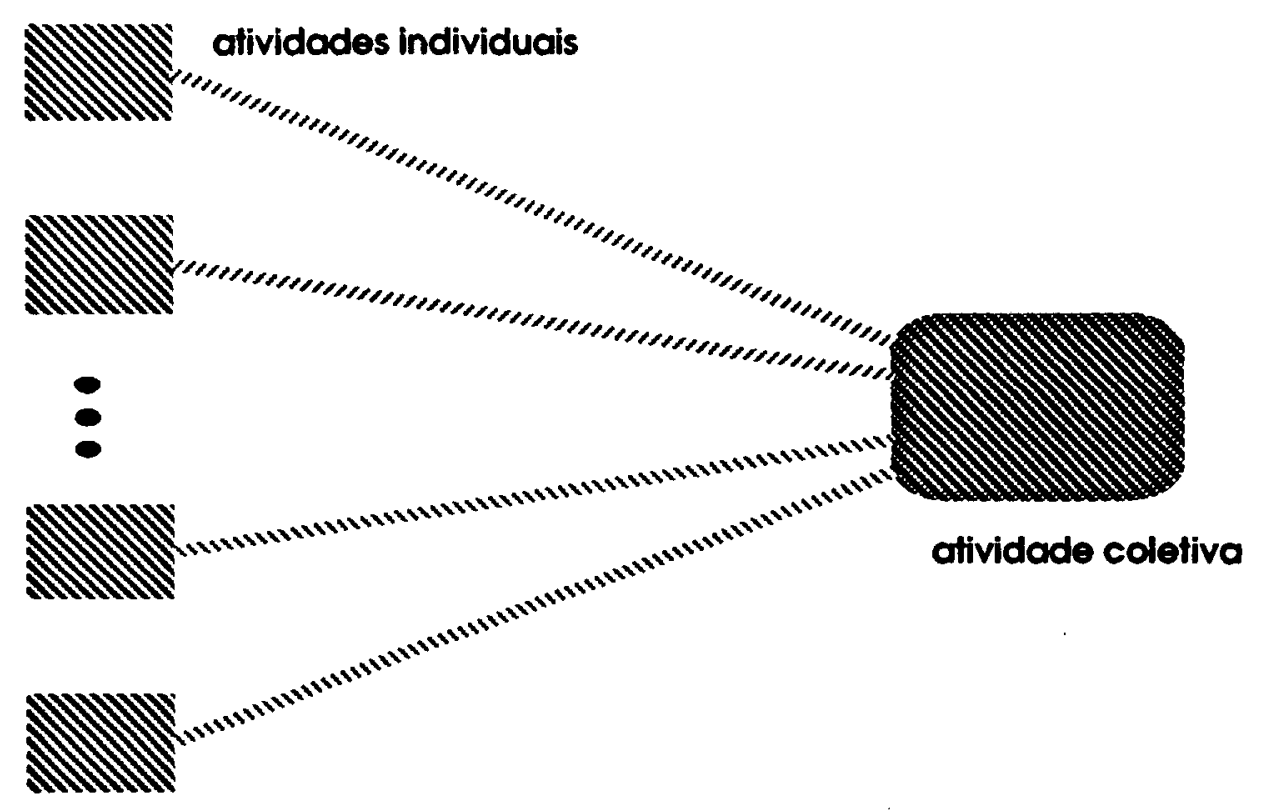

\section{Figura 5.3}

Atlvidades individuals $\theta$ coletlva (cf. (33)).
Operações. As questðes operacionais são implementadas através de uma série de operações. Cada operação corresponde a uma condição material concreta (física ou social) para a implementação das açōes, e é disparada pelo surgimento destas condições materiais concretas específicas. As operaç̃es são unidades sensório-motoras que um ser humano realiza em uma situação espećfica, inconscientemente, para completar as ações das quais possui consciência.

Os indivíduos possuem um certo repertorio de operações. Este repertório é parte das condições de uma atividade específica porque ele forma a base a partir da qual as operações são ativadas ao encontrarem as devidas condições materiais concretas. Para cada ação concreta, o ser humano depende da ativação de uma sequiência de operaçбes. Se esta ativação não ocorre, é necessário realizar conscientemente outras açães. Geralmente, a pessoa realiza ações mais detalhadas devido a falta de certas operaçóes. As açōes podem ser operacionalizadas, ou seja, transformadas em operaçð̃es. As operaçð̃es, por sua vez, podem ser conceitualizadas. A conceitualização significa articular 0 que por si só já é evidente.

O ser humano não é consciente das operaçð̃es utilizadas em uma ação específica. Mas através da conceitualização, as operações podem se tornar conscientes da mesma forma que as açס̃es. As pessoas podem nomear uma seqüência específica de operações e compreender e fornecer razões para sua aplicação em um nível que corresponde ao nivel anterior das açð̃es. Em situaç̋̃es especificas, ou após a execução de uma atividade especifica, pode-se indagar de uma pessoa como ela fez e por que fez o que fez.

A conceitualização pode ocorrer em situações de colapso (veja Capítulo 4), que são situações nas quais algum tipo de conflito inesperado ocorre entre as condiçð̄es esperadas para as operações e as condições reais. Bødker destaca que, "para os propositos do design, é interessante dar atenção às características das operações e suas condições materiais: ao realizar um design, vamos modificar as operações e suas condições para uma determinada atividade e, por esta razão, precisamos olhar tanto para as operações e condições atuais, quanto para as futuras modificações" [33].

No entanto, uma pessoa não consegue prever suas futuras operações em uma futura ação. Ela não saberá disso até que as tenha realizado; as operações são ativadas pelas condições materiais, pela confrontação com a natureza ou a cultura do momento, e não por qualquer conjunto quantificável de condiçð̃es. Pode-se dizer que, geralmente, as operações não são articuladas, as pessoas não estão conscientes delas, mas podem ser articuladas após os fatos ou os colapsos ocorrerem. Já as condições materiais, muitas ve- 


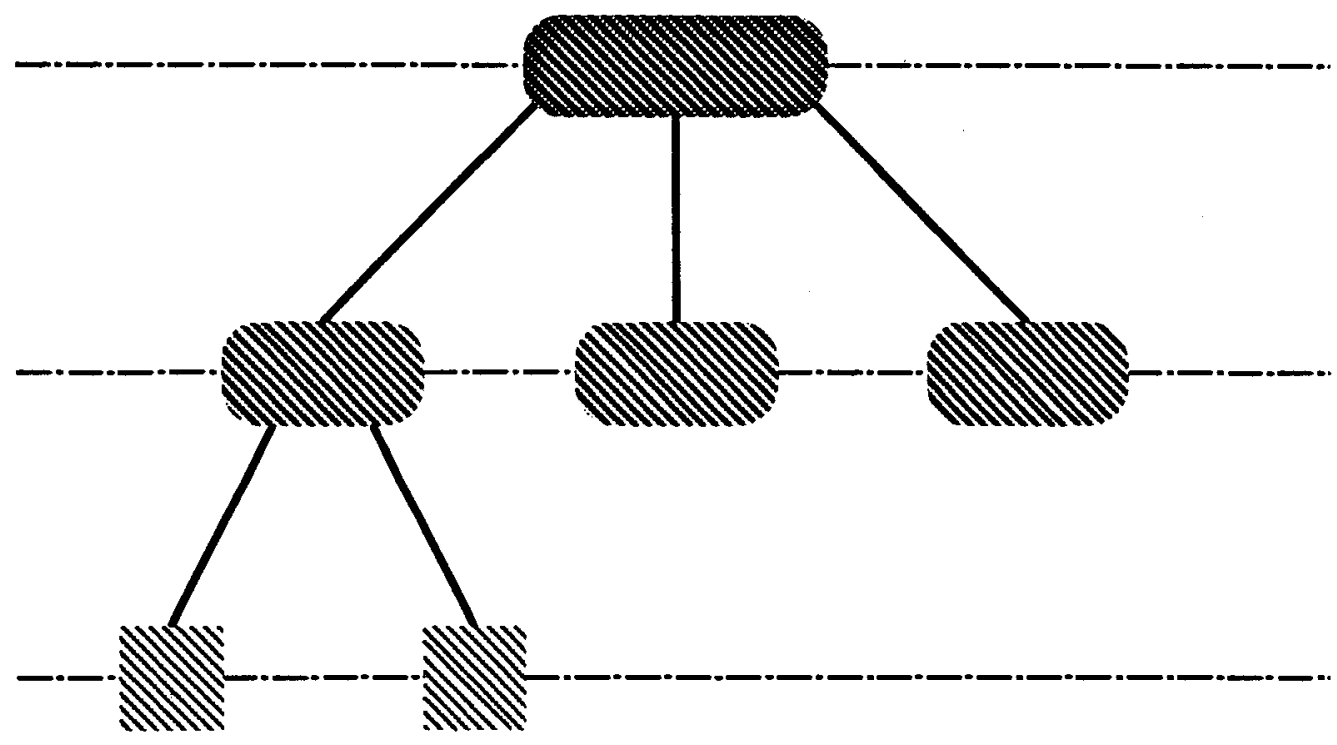

zes, são inarticuláveis, istoé, as pessoas nãopodem articular qual conjunto de condições materiais vai fazer com que se use esta ou aquela operação. Isto dá a uma ação um certo senso de imprevisibilidade. Mesmo sendo possivel saber alguma coisa sobre qual repertơrio de operações um ser humano possui com relação a algum propósito, nem a própria pessoa, nem um observador podem prever quais operações serão usadas em uma situação de uso espećfica.

Prática. Um grupo de seres humanos que realiza uma atividade coletiva com um objetivo ou meta espećfico partilha de uma prática. A prática de um grupo nasce a partir, e é alcançada através, de um objetivo ou meta comum, assim como pelas condiçães para a atividade coletiva - como os materiais e a organização ao redor do grupo - e pelos meios de produção da atividade. A prática se reflete pelo repertório de operações de um membro do grupo, ao mesmo tempo que o indivíduo toma parte na constituição e produção da prática do grupo através de sua ações e operações.

Os meios de produção de uma atividade são importantes portadores de prática. As técnicas culturais, que são maneiras espećficas de fazer coisas, além da linguagem falada, pertencem a uma categoria de meios: elas podem ser explicitadas através da articulação do que for inarticulado, mas somente estarão presentes na atividade através das ações e operaçס̃es realizadas por pessoas sobre objetos físicos ou sujeitos. A linguagem escrita e os artefatos, os quais podem ser externalizados ativa ou passivamente, podem estar presentes nos objetos independentemente das ações de uma pessoa. Um artefato externalizado passivamente auxilia na implementação que uma pessoa faz de certas operações, às vezes substituindo outras operaçōes anteriores. Na cozinha, uma máquina de fazer pão é um exemplo de um artefato externalizado ativamente, enquanto uma xícara é um exemplo de um externalizado passivamente.

Alguns aspectos da prática podem ser explícitos. Eles podem ser formulados como guidelines e teorias. Eles representam os aspectos articuláveis de uma prática. Por outro lado, apenas através de experiências práticas uma pessoa pode aprender as diferenças existentes entre um conjunto de ações e operações e outro. Apenas através da experiência prática as pessoas podem operacionalizar açôes, de maneira a que, mais tarde, as operações corretas sejam ativadas pelas condiçóes adequadas. Estes aspectos são chamados de pessoais ou tácitos.

Construir um repertório de ações e operações é um dos resultados do aprendizado e da socialização de um grupo de seres humanos como, por exemplo, um grupo de trabalhadores qualificados em uma prática coletiva. Mas dominar uma prática não significa atividade

oçסos

operaços

Flgura 5.4

Atlvidade, açoss $\theta$ operaçoes (ct. (33)). 
ser capaz de realizar certas operações nas quais certas linguagens e artefatos são utilizados. Uma prática reflete tanto os aspectos comunicativo e instrumental das ações e das atividades, e também, tanto as questões operacionais quanto as intencionais. Dominar uma prática significa conhecer os meios, ou as intençôes que estão por trás das palavras e da forma de se organizar um trabalho. Um aprendiz precisa saber não apenas como 0 trabalho está organizado e como os produtos aparecem a partir desta ou daquela forma de organização, mas também o que significa um pedido feito por um especialista para se executar determinada tarefa em comparação com o mesmo pedido feito por um aprendiz. Realizar operações e ações específicas para criar um determinado produto a partir de certos materiais e utilizando certos artefatos não é a única coisa importante, mas também saber distinguir a qualidade dos materiais, reconhecer um bom produto, e assim por diante. Bødker destaca que "é através das intenções que questões como qualidade dos materiais e dos produtos tornam-se comunicáveis entre seres humanos que partilham a mesma prática, enão porque cada indivíduo é capaz de explicitar as escolhas que foram feitas e suas razões para isso, mas porque o grupo partilha valores e experiências".

Aspectos comunicativos e instrumentais. Tanto o aspecto comunicativo quanto o instrumental de uma atividade humana são formados por operações e ações. O que do lado ins-trumental existe como uma determinada combinação de ações realizadas através de operaçð̃es ativadas pelo surgimento das condições materiais, no lado comunicativo é uma combinação de ações realizadas através de operações ativadas por ações e operações comunicativas realizadas por outro ser humano. Este encontro será mediado pela linguagem, mas, talvez, também por artefatos como o telefone. A interpretação das locuções está baseada tanto nas práticas de comunicação dos parceiros, que eles partilham de alguma forma, quanto no conjunto de operações ao redor da comunicação, como, por exemplo, se um dos parceiros pode dar ordens ao outro ou não.

Os objetos e sujeitos para os quais as pessoas dirigem as ações e operações não são apenas "natureza", eles fazem parte de uma determinada cultura. As pessoas geralmente partilham com os sujeitos alguma prática, e apenas em rarasocasiões mesmouma prática comunicativa não funciona. Em relação aos objetos, as pessoas geralmente encontram artefatos, objetos feitos pelos homens. Os artefatos não foram construidos para serem objetos de trabalho, mas para mediar nossa relação com outros objetos. Os artefatos podem ser 0 objeto de açōes e operações se estas visam produzir 0 artefato, mas os artefatos podem se transformar em "natureza" se as operações não funcionarem (veja, no Capítulo 4, "Colapsos").

Aprendizagem. Para Bødker, “aprender significa a socialização da prática de um grupo através da leitura da teoria e da experiencia prática". Neste processo, uma pessoa necessariamente não precisa ser capaz de reproduzir todos os detalhes de uma prática. Podese dizer que ela ainda não atingiu o nível de competência de um especialista que domina uma determinada prática, em relação a esta prática especffica. Aprender também é fazer com que o grupo transcenda esta prática.

Uma importante parte da aprendizagemé a de construir um repertório de operações. Quando um novo artefato étrazido para dentro de uma prática, esta prática se modificará. Mesmo o mais experiente especialista provavelmente terá que modificar seu repertório de operaçōes e, por um momento, ele retornará a um nível anterior de competência. Por 
esta razão, afirma Bødker, é importante saber como aprendemos a usar um novo artefato e como isto se diferencia dentro da atividade de uso rotineira. Além disso, é importante saber quais impactos esta diferença irá ter no próprio design do artefato.

Bødker apresenta um sumário sobre como a teoria da atividade humana encara as pesquisas e discussões sobre como os seres humanos aprendem e, em particular, como criam seus repertórios de operações, que está reproduzido abaixo.

\section{- A atividade sobre objetos materiais não pode ser aprendida sem experiência prática.}

- A atividade que tem uma meta abstrata, como resolver um problema matemático, é mais fácil de ser aprendida se estiver conectada com objetos físicos do que com representações abstratas. Aprender com representações é, por sua vez, mais fácil com a ajuda da linguagem, que é mais fácil do que uma atividade totalmente baseada em reflexōes mentais.

- Quando ocorre uma operacionalização, inicialmente ela é muito especifica de uma situação, mas, conforme uma pessoa encontra novas condiçøes, cresce o número de situações que podem ser manipuladas.

- Para o novato, a atividade ocorre a um nível muito detalhadodas ações, onde cada ação é cuidadosamente planejada. Com a experiência, isto toma a forma de uma totalidade operacionalizada. Isto ocorre através da generalização, através da operacionalização de ações planejadas, e através da abreviação, uma operacionalização por omissão de certas operações graças às condições dadas e a um conhecimento do resultado que será obtido.

- Uma pessoa passa de um nível de competência para outro seja devido a um questionamento pedagógico das operações anteriores e de suas condições, seja porque ela esteja tentando aplicar operações antigas a um novo artefato e esteja encontrando um colapso. A rapidez da mudança e se a pessoa vai continuar no mesmo nível ou avançar, dependem do artefato, dependem de quanto a pessoa pode confiar em suas generalizações, dependem do tipo de educação que recebeu, $\mathrm{e}$ dependem se a pessoa pode usar as experiências de outros tipo de atividades.

- Se um artefato funciona corretamente, seu uso é operacionalizado. Idealmente, a aprendizagem começa com ações direcionadas para 0 artefatoe termina sem estas ações.

O mais importante para o design de um artefato é ser contruido a partir da prática de trabalho existente de maneira a evitar de se transformar usuários experientes em novatos, tanto no que se refere à prática geral da atividade quanto ao uso especifico do artefato. Além disso, o design modifica a prática ao introduzir o novo artefato, mas a prática também pode ser influenciada pela educação: o desafio é o de criar através do design a educação necessária para alterar a prática de maneira a fazer uso do artefato. Bødker enfatiza esta afirmação dizendo que "o design é um processo de aprendizado para os participantes, isto é, se usuários competentes tomarem parte no design, tanto a sua prática geral quanto a especifica em relação ao artefato serão modificadas enquanto a atividade estiver ocorrendo". 


\section{Aplicaçōes computacionais}

Nesta seção, seguindo o trabalho de Bødker, a idéia é a de desenvolver uma concepção de artefatos computacionais - especialmente interfaces com o usuário - baseada na teoria da atividade humana e que possa ser aplicada pelo design. Esta concepção não é necessariamente reconhecida pelo usuário em uma espećfica situação de uso: ela pertence ao dominio do design da aplicação computacional. Neste dominio, a aplicação é um objeto para a atividade. No domínio de uso, um determinado artefato computacional possui um significado como qualquer outro artefato com o qual as pessoas trabalham: o de artefato e não como um objeto sobre o qual trabalham.

Quando o foco de atenção passa da atividade humana para os proprios artefatos, é necessário um novo vocabulário. Nao se pode mais falar sobre a atividade do usuário, seus objetivos, intenções, ações e operações, mas sobre artefatos, o tipo de atividade humana que eles devem (ou deveriam) auxiliar, o tipo de prática do qual eles fazem parte, etc.

Os artefatos são objetos que intermediam as ações de uma pessoa em direção a outro sujeito ou outro objeto. Quando um artefato é usado, as pessoas dirigem ações e operações tanto para o artefato quanto para o sujeito ou o objeto, açס̃es e operações estas dirigidas através do artefato. Em situações onde uma ação pode ser vista como comunicativa, algumas das operaçoes que a realizam podem ser instrumentais e vice-versa.

Tradicionalmente um artefato evolui de maneira lenta, um processo que leva anos. Geralmente o designer é um competente artesão, e existe uma relação muito estreita entre o designer e os usuários, de tal forma que o feedback do uso muitas vezes leva a novos passos no design.

Artefatos computacionais. Os artefatos computacionais são desenvolvidos muito rapidamente. Eles são complexos e exigem a cooperação de diferentes tipos deespecialistas. Raramente os designers são membros competentes da futura comunidade de usuários e, muitas vezes, não existe feedback dos usuários, porque os designers vão para novos projetos em outras áreas de aplicação. Além disso, os designers geralmente não são especialistas sequer em design, não possuindo o repertório de operações para lidar com design e, portanto, têm a tendéncia de seguir métodos de design como se fossem receitas (veja Capítulo 3).

As aplicações computacionais são, por definição, externalizadas ativamente, epodem ser aplicadas para sustituir o que anteriormente eram operaçōes humanas. Em muitos casos, os artefatos computacionais, se comparados com artefatos tradicionais, não permitem o acesso direto ao sujeito ou ao objeto das ações realizadas através do artefato. As pessoas não podem ver, ouvir ou sentir diretamente o sujeito ou o objeto, dependendo apenas das representaçóes fornecidas pelo computador. Faz parte da capacidade humana projetar suas experiências com um objeto em outro objeto ou acoplar estes dois tipos de experiências. Da mesma forma que uma pessoa cega utiliza uma bengala para "enxergar" quando anda pelas calçadas de uma cidade, os seres humanos podem acoplar suas experiências através do aplicativo com o objeto real e vice-versa. Os sujeitos não precisam estar presentes: $o$ encontro de dois sujeitos pode ser um encontro entre um dos sujeitos e uma parte do aplicativo computacional no lugar do outro sujeito. Este relacionamento dá aos aplicativos computacionais uma certa flexibilidade porque é fácil fazer com que um aplicativo intermedie a relação entre o usuário e vários sujeitos ou 
objetos diferentes. $O$ aplicativo computacional passa a ser 0 artefato de várias atividades diferentes e a alternância entre objetos/sujeitos passa a fazer parte do que o usuário faz enquanto utiliza 0 aplicativo.

A questão aqui não é dizer que os artefatos computacionais sejam muito diferentes dos artefatos tradicionais, mas sim dizer que eles podem ser muito diferentes mesmo quando executam um papel no uso como os tradicionais. Quando as pessoas deixam de falar de uma atividade de uso especifica e passam a falar de um artefato específico, elas não podem mais falar sobre um objeto, um repertório de operações, etc. É necessário falar sobre um número de objetivos ou metas, ou de um certo tipo de objetivos ou metas, sobre determinados tipos de sujeitos e objetos sobre os quais os usuários do artefato podem realizar certas ações, e assim por điante. Sem uma situação de uso específica, as pessoas só podem falar sobre intenções. Os artefatos computacionais foram criados para dar apoio a um tipo especifico de atividade. Eles nasceram a partir e por causa de uma prática específica. Eles nasceram a partir de várias outras condiçóes para este tipo de atividade.

Em uma determinada atividade onde $o$ artefato for usado, o usuário pode realizar alguma ação em alguns objetos através do artefato, outras ações sobre alguns outros objetos ou sujeitos, e ainda outras sobre o artefato enquanto objeto. Algumas destas ações podem fazer parte dos aspectos comunicativos da atividade humana e outras dos aspectos instrumentais. Tradicionalmente, alguns artefatos foram criados basicamente para atender os aspectos instrumentais e outros para os aspectos comunicativos. Para muitos dos aplicativos computacionais, esta distinção não é muito clara, porque os aplicativos intermediam açôes e operações tanto para objetos quanto para sujeitos.

A interface com o usuário. Ao aceitar determinadas ações, o artefato computacional aceita tanto aspectos intencionais quanto operacionais - o quê pode ser feito através do artefato e como isto pode ser feito. Tradicionalmente, as pessoas associam os aspectos intencionais com a funcionalidade de um sistema - oquê pode ser feito através do aplicativo. Esta noção pertence d tradição racionalista apresentada no Capítulo 3. Enquanto esta tradição acredita que a ati vidade humana é conscientemente planejada, para a abordagem da atividade humana, a funcionalidade pode ser vista como algo que só se revela durante colapsos. Nestas situaçóes é possível perceber as propriedades dos resultados do processo de uso - sobre o que foi feito - pressupondo uma situação de uso.

As condiçôes que são dadas pelo aplicativo computacional para os aspectos operacionais compõem o que é chamado de interface como usuário. A interface com o usuário representa as condições limites do artefato para como as ações podem ser realizadas. As partes constituintes desta interface podem ser tanto as condiçð̃es para as operaçð̄es direcionadas ao artefato quanto para as operações direcionadas em diferentes níveis aos sujeitos ou aos objetos. Para Bødker, desta forma, é possivel definir a interação homemcomputador como "a operação humana de um aplicativo computacional".

A interface com o usuário aceita ações direcionadas para diferentes sujeitos e objetos com os quais o usuário tenciona lidar através do artefato. Mas o artefato como tal é transparente no sentido de que pode não ser um objeto para as ações do usuário durante o uso regular.

Como é possível distinguir quando o usuário está manipulando um objeto no ou através do artefato, e quando ele está se comunicando com outro ser humano através do artefato? Os diferentes tipos de situaçőes podem ser descritos como (segundo Bødker): 


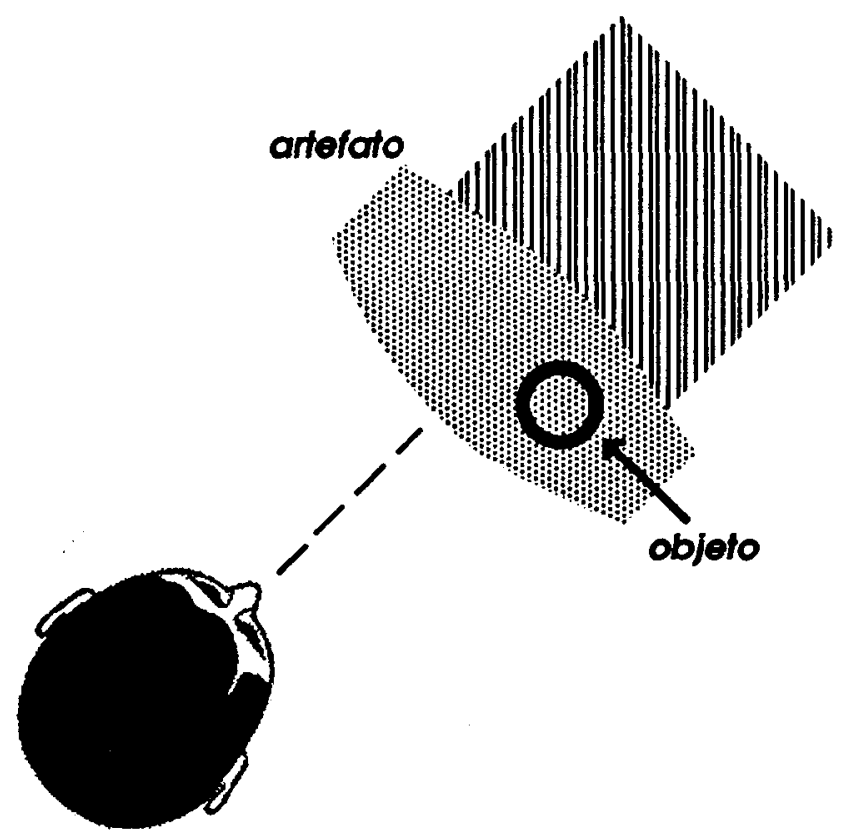

Figura 5.5

Objeto está presente apenas no artefoto (cf. (33)).
1. O objeto está presente apenas no artefato. Uma planilha de cálculo é um exemplo desta situação: ela não possui nenhuma relação com os objetos fora do artefato (a planilha impressa não possui as mesmas capacidades da planilha). A qualidade da interface com o usuário precisa, para este tipo de artefato, estar associada com a possibilidade do usuário poder distinguir entre 0 manuseio do artefato e o manuseio do objeto dentro do artefato (veja Figura 5.5).

2. O objeto também existe como objeto físico, mas só está presente na atividade de uso como uma representação no aplicativo computacional. O processador de texto é um exemplo desta situação: o objeto é uma carta que só está presente na atividade de uso como aquilo que pode ser visto e manipulado na tela. A qualidade da interface com o usuário para este tipo de aplicativo precisa estar relacionada à forma pela qual o usuário acopla o objeto final e o objeto representado na tela. Este é um tipo de situação onde se pode ver partes da interface como um filtro entre o objeto como é apresentado na atividade de uso e o objeto real (veja Figura 5.6).

3. O objeto esta fisicamente presente fora do artefato. Os diferentes tipos de painéis de controle são exemplos desta situação, onde o objeto é manipulado através do artefato mas também está acessivel para inspeção. Para este tipo de interface com o usuário, a qualidade também está relacionada com as possibilidades de se acoplar o que é obtido através do artefato com o que está realmente acontecendo com o objeto (veja Figura 5.7).

4. O outro sujeito não está presente na atividade de uso. Um sistema de correio eletrónico é um exemplo desta situação. Aqui, também deve ser possível para o usuário fazer o acoplamento entre como o outro sujeito é percebido através do artefato e o sujeito real.

5. Os sujeitos estãopresentes fisicamente mas se comunicam (parcialmente) através do artefato. Alguns projetos de sistemas de apoio ao trabalho cooperativo (como o Xerox Colab) são exemplos deste tipo de aplicativos.

Bødker caracteriza diferentes aspectos da interface com o usuário baseando-se nas distinções entre os diferentes objetos/sujeitos para os quais os seres humanos direcionam suas operações, e nos papéis e características especificos destes objetos/sujeitos em uso. Esta distinção é feita entre: 


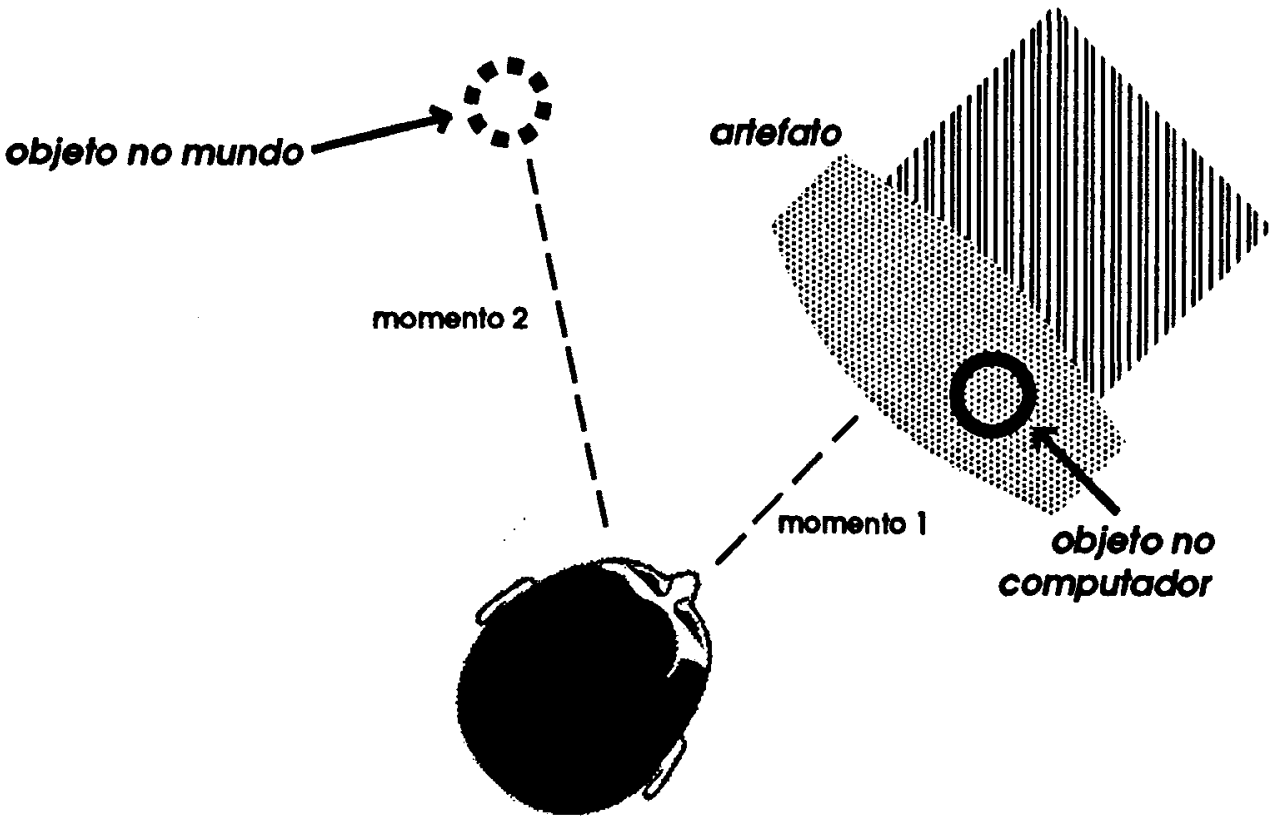

- Os aspectos físicos, o suporte para as operações direcionadas ao aplicativo computacional como um objeto físico. As pessoas encontram este objeto em um colapso total ou antes de conhecer o aplicativo. Os aspectos físicos são as condições para a manipulação física do artefato. As pessoas se adaptam às forma e configuração do artefato, e uma má adaptação pode impedir a formação de certas operações.

- Os aspectos de manipulação, o suporte para as operações direcionadas ao aplicativo computacional. Um colapso nestas operações fará o artefato aparecer para as pessoas comoum objeto. Os aspectos de manipulação compöem as condiçбes para a transparência do artefato. Comoo artefato é uma objeto, estas operaçð̄es são inerentemente instrumentais, não importando se as açð̄es são comunicativas ou instrumentais. Em uma situação de colapso, por exemplo, este tipo de operação pode ser conceitualizada, por meio da qual o usuário pode ser forçado a realizar ações direcionadas ao artefato como um objeto.

- Os aspectos relativos ao sujeito/objeto que constituem as condições para as operações direcionadas aos objetos ou sujeitos com as quais os usuários lidam no artefato ou através do artefato. Diferentes partes dos aspectos relativos ao sujeito/objeto estão relacionadas a diferentes sujeitos ou objetos, mas também faz parte destes aspectos a alternação entre sujeitos/objetos.

Os aspectos físicos podem ser mais tangíveis ou manifestos do que os outros, o que pode sugerir que eles teriam um status diferente. Isto é verdade, segundo Bødker, apenas de uma forma: os aspectos físicos compóem a natureza que as pessoas podem sentir, ver e ouvir em uma situação de colapso total. Culturalmente, noentanto, todos os três aspectos são dependentes uns dos outros na prática. Para o usúrio competente, todos os aspectos estão igualmente presentes em uma especffica atividadedeuso:os trêsconstituem a totalidade e a possibilidade de alteração entre os aspectos.

Os aspectos físicos e os de manipulaçðo são condições para possíveis operaçđ̃es direcionadas ao artefato e ações direcionadas ao sujeito/objeto. Os aspectos relativos ao sujeito/objeto acrescentam as condições para possíveis operações direcionadas ao sujeito ou ao objeto. Nas atuais situaçð̌es de uso, podem ocorrer colapsos entre quaisquer dois sujeltos/objetos, e uma operação direcionada a um sujeito/objeto pode ser um pré-

Flgura 5.6

Objeto também exlste fisicamente, mas só esto presente como uma representaçăo no apllcativo (ct. (33)). 


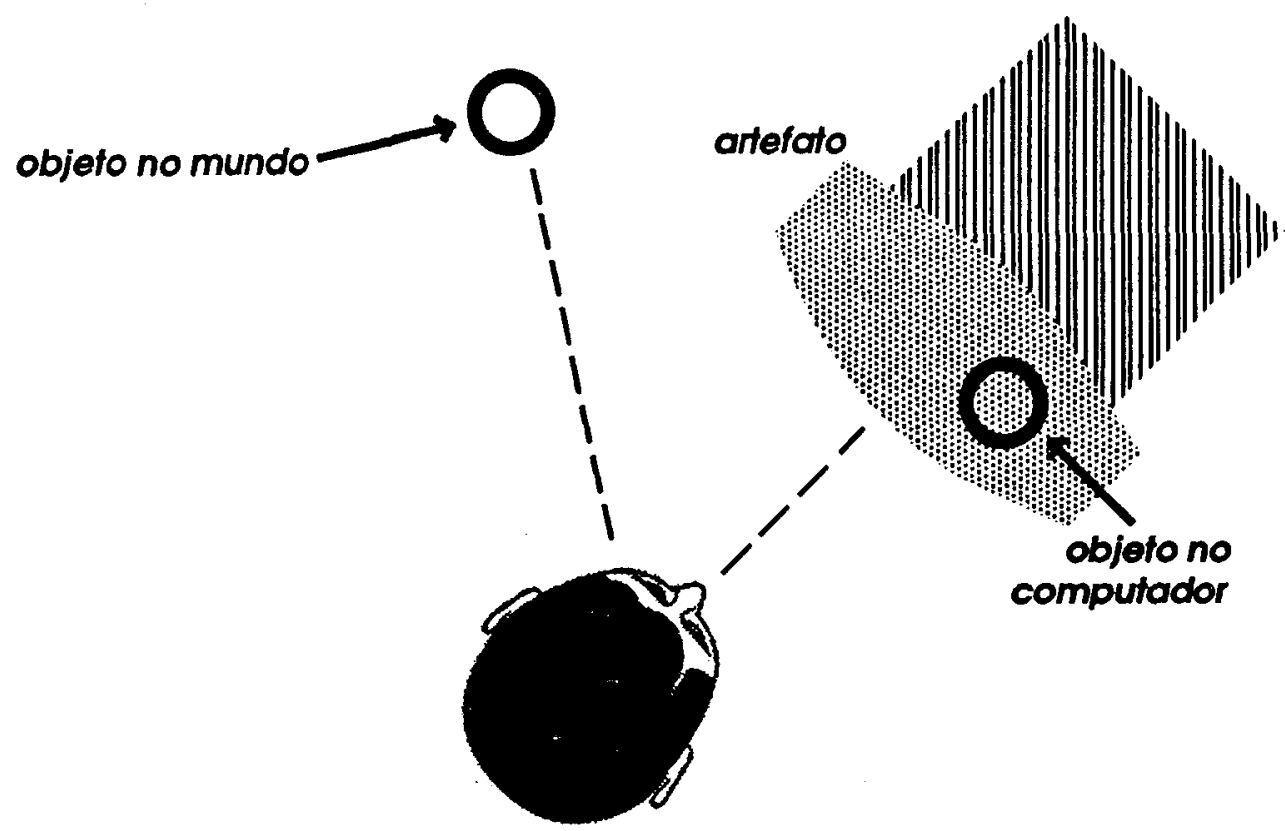

Figura 5.7

Objeto estó fisicamente presente fora do artefato (cf. (33)). requisito para uma ação ou operação direcionada a outro sujeito/objeto. Deste ponto de vista, os três aspectos são independentes, mas um software ou um hardware pode ser formado por várias partes dos aspectos (veja Figura 5.8).

A interface com o usuário, como afirma Bødker, só se revela totalmente para o usuário através do uso.

\section{Design de artefatos computacionais}

Realizar um design com a atividade de uso futura em mente também significa partir das práticas atuais dos futuros usuários. É através das experiências destes usuários que nasceu a necéssidade de um design, e é esta prática específica que deve ser aplicada e modificada na atividade de uso futura. O design de artefatos computacionaisé um ponto de encontro de várias práticas diferentes, onde a troca de experiências é algo que exige um esforço deliberado. O design é um processode aprendizagem, visto pelos participantes tanto como um processo coletivo quanto como individual. Os diferentes grupos envolvidos aprendem sobre a prática dos outros grupos participantes. Para os especialistas em computação, isto significa aprender sobre o trabalho e os pré-requisitos do domínio do aplicativo. Para os usuários significa que a aprendizagem sobre computadores é combinada com a aprendizagem sobre o design de aplicativos computacionais. Para todos os grupos, o contato com práticas de outros grupos contribui para a aprendizagem da própria prática, o que revela um aspecto criativo do design: as possibilidades de conhecer novas maneiras de fazer algo, que transcende as práticas tradicionais.

O design está baseado nas práticas dos usuários mas pode modificar todos os seus aspectos. A conceitualização, o processo de tornar consciente a natureza das práticas humanas, ocorre em diferentes situaçðes e é ativada por diferentes significados. Em design, é necessário conhecer todos os significados que ativam a consciência sobre todos os aspectos da prática enquanto, ao mesmo tempo, é necessário perceber que alguns dos aspectos tácitos da prática são melhor tratados sem a atuação da conceitualização. Neste processo, surgem duas metas de design potencialmente conflitantes: a de que os futuros usuários devem ter acesso ao artefato-que-será-construido; e a deque a equipe de desenvolvimento precisa de uma base formal e detalhada para a sua programação. Este conflito potencial pode ser resolvido de duas formas: permitindo que os usuários consi- 


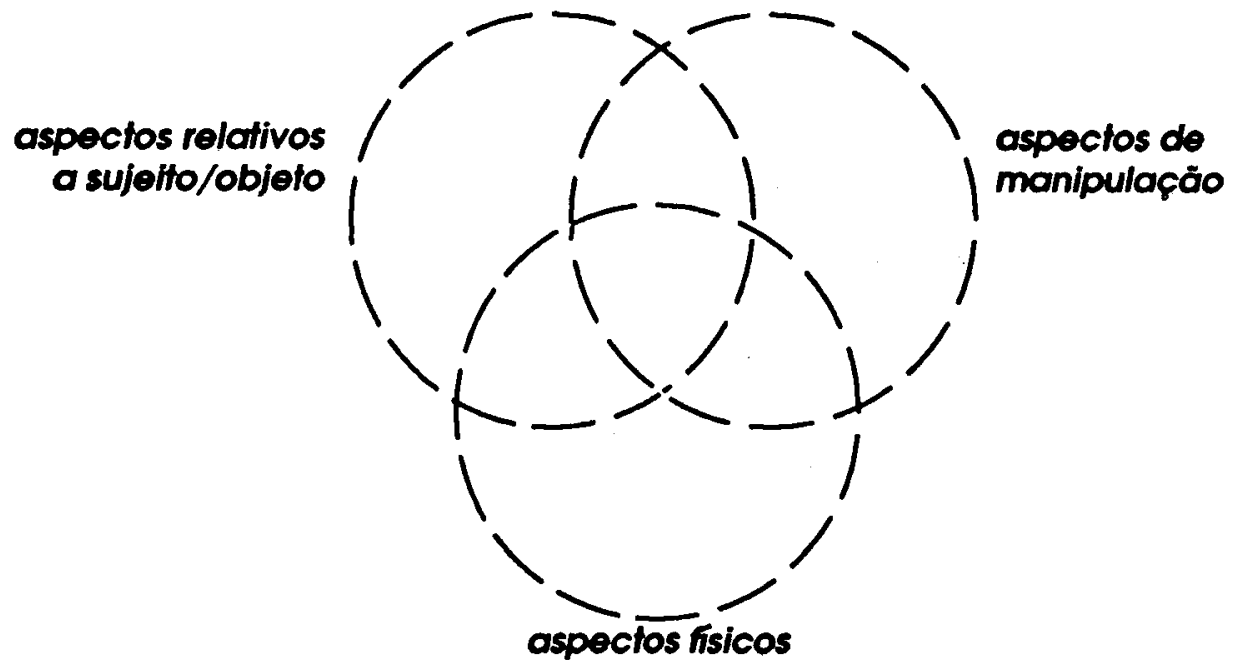

gam detalhar e explicitar seus requisitos da maneira mais completa possível; ou fornecendo d equipe de desenvolvimento a necessária competência para participar do design e auxiliar na transformação dos colapsos em programas. O quadro de referência da atividade humana diz que a primeira opção é muito difícil de ser alcançada. A segunda enfatiza a necessidade de um processo coletivo de aprendizagem entre os grupos envolvidos no design. Além disso, ser um bom designer significa ser capaz de facilitar a reflexão e a transformação em situações de colapso.

Qualquer ação de uso de um artefato possui aspectos intencionais e operacionais. O design muitas vezes começa a partir dos aspectos intencionais porque eles se tornam aparentes durante colapsos, e as pessoas são capazes de comunicar diretamente suas intençס̃es. No entanto, para compreender totalmente um artefato, é preciso começar pela atividade de uso. Esta é a única maneira de também levar em conta os aspectos operacionais do uso e, portanto, da interface com o usuário e do artefato em uso.

Fazer o design de um artefato significa mais do que criar um objeto que possa ser usado por seres humanos como artefatos em uma determinada atividade. Como o uso de artefatos faz parte de uma atividade social, é necessário fazer o design das novas condições para a atividade coletiva, por exemplo, nova divisão do trabalho e novas formas de coordenar, controlar e comunicar. O designé uma atividade fundamentalmente coletiva na qual as várias práticas dos participantes se encontram para realizar um processo de aprendizagem mútua. A educação e o treinamento também são importantes, porque o artefato está para ser integrado em uma prática já existente. Esta integração modifica não só os aspectos operacionais do artefato como também os outros aspectos da prática (metas, propósitos). Uma boa educação pode facilitar esta modificação.

Prática dos designers. É possível fazer uma distinção entre os dois tipos de atividades nas quais se faz uso da conceitualização: as atividades de investigação, onde, a partir de uma prática, busca-se alterar um artefato; $e$ as atividades de comunicação, onde artefatos novos ou alterados são avaliados e o resultado pode ser uma prática modificada.

A conceitualização pode ser alcançada através do uso de artefatos e técnicas (que serão apresentadas no Capítulo 6) pelas quais se constrói uma visão materializada da futura atividade de uso, incluindo o artefato. Em outras palavras, a simples criação, assim como a visão materializada, pode servir como ativador. Exemplos destes ativadores são as técnicas de cenário, as de descrição de sistemas, e a prototipagem. Como destaca Bødker, "a visão materializada é a maneira pela qual se pode fixar e materializar idéias sobre os diferentes aspectos do futuro artefato ao mesmo tempo que podem servir como
Figura 5.8

Interrelaçăo entre os aspectos de uma interface (ct. (33)). 
pontos de referência para a comunicação entre os grupos e individuos envolvidos no design. Existem dois objetivos para se criar estas visões materializadas: a comunicação e a própria construção" [33].

Os métodos de design atuam como meios de mudança para a prática dos designers. Os métodos fornecem prescriçø̃es para o uso de certos meios de design em busca de uma atividade de design total ou de atividades de design com objetivos mais específicos. De acordo com L. Mathiassen (citado por Bødker), os métodos de design prescrevem o uso de certos artefatos, técnicas, e princípios de organização em correspondência com técnicas culturais, linguagens, artefatos e formas de organizar o trabalho que os designers utilizam como parte da prática de design. Os meios prescritos, em conjunto com um domínio de aplicação mais ou menos explícito e uma perspectiva, formam o delineamento de uma prática: os métodos são criados pelos designers que acreditam conhecer uma boa maneira de fazer design em um certo domínio. No entanto, partes importantes de suas experiências se perdem, e apenas as partes explícitas de sua competência são capturadas pelo método. Para o uso de um método, isto tem a consequiência de que um método não é uma receita para ser seguida passo-a-passo, como um computador executando um programa, mas sim como um conjunto de guidelines para um certo tipo de atividade a ser aprendida pelos designers e posteriormente aplicada através do repertório de ações e operações.

Oproblemaéque muitas vezes os métodos tentam compensar a falta de competência da equipe de desenvolvimento. Ao sugerir uma forma de organizar o trabalho e o uso de certos meios para o design, se faz a apologia de uma menor quantidade de competência em design para os próprios designers. Mas, com menor competência - como em qualquer tipo de atividade humana de trabalho - o repertório de açóes e operações dos designers tem uma repercussão na qualidade do produto, já que eles estão incapacitados de atuar de acordo com a situação encontrada.

Design de interface com o usuário. Em design, é necessário lidar com os aspectos articulados, não-articulados e inarticuláveis de uma prática e com a conceitualização em relação a estes aspectos. Neste sentido, a interface com o usuário é um desafio especial: operações podem ser conceitualizadas como operações e tornadas específicas através de vários meios, por exemplo, escrevendo as operações ou ensinando-as a outras pessoas. No entanto, como destaca Bødker, "o que se deve investigar no design de interface com o usuário são as condições que ativam uma certa operação do repertório de operações". Os atuais ativadores de uma combinação de ações e operações em comparação com outra faz parte da competência pessoal. Isto significa que apenas os colapsos podem despertar a atenção para os ativadores e as condiçoes atuais de ativação. Ao utilizar um repertório de operaçães sob diferentes circunstâncias - como outras interfaces com o usuário e diferentes situações materiais ou de comunicação - a ocorrência de um colapso pode ser testada e pode revelar as condições para a escolha de operações. Os aspectos físicos, assim como os de manipulação e os relativos a sujeito/objeto, da interface so podem ser examinados através das atuais situações de uso.

A interface com o usuário, para Bødker, cria as condiçбes através das quais o artefato não se antepõe a atividade direcionada aos sujeitos ou objetos reais da atividade. "Design é um processo que leva de uma situação onde ocorrem numerosas formas de conceitualização, sobre os artefatos anteriores, sobre prática, etc, para uma situação onde os artefatos não ocasionam colapsos e onde é possivel criar o necessário repertório de ações e operações direcionadas ao objeto ou sujeito" [33]. 


\section{Métodos para design de interfaces}

As equipes de desenvolvimento precisam modificar seus métodos e padrões. Os designers como indivfduos e como membros destas equipes precisam alterar suas práticas para poderem lidar com as novas tecnologias. Encontrar o método correto para construir uma interface com o usuário não é uma tarefa fácil. A maior parte dos métodos existentes não deixa claro qual perspectiva está sendo usada, o que impede a previsão de qual tipo de interface ou aplicativo será construído. Bødker propóe uma taxonomia dos métodos de design que é basicamente prescritiva sobre o processo de design. $\mathrm{O}$ objetivo desta taxonomia é o de revelar que tipos de interface são inerentes à aplicação de um método especffico. A taxonomia está estruturada a partir das seguintes áreas:

- Domínio de aplicação, metas, objetivos e propósitos. Um método traz consigo, muitas vezes de maneira implícita, um domínio de aplicação que revela alguma coisa sobre qual o tipo de mudanças organizacionais e de aplicativo computacional que formam a meta ou o objetivo da atividade total. Um método para o design de aplicativos financeiros pode ser muito diferente do que um método para o design de aplicativosinovadores ou especfficos para um determinado propósito. Os propositos, objetivose metas prescritos por um método, assim como os tipos de visõesque serão usados, têm importantes consequiências para que tipos de interfaces serão construrdas e como isso será feito, quando o método for aplicado.

- Meios de produção do design, colapsos e prática de uso. Os meios de produção do design, ou as diferentes técnicas e artefatos sugeridos pelo método, trazem consigo a perspectiva do método, e através de seu emprego os usuários irão adotar seu ponto de vista e sua "cegueira". Dois aspectos são importantes neste item: o papel da prática de uso e o conhecimento sobre colapsos em design. Os métodos devem tratar diferentemente os aspectos articulados, não-articulados e inarticuláveis do uso. Devem, também, prescrever os propositos comunicativo e instrumental das atividades de design. - Propriedades do produto. A distinção entre as ações e operações instrumental e comunicativa é importante não apenas para os propósitos das atividades de design, mas também para o produto do design. Por exemplo, será que o futuro artefato irá apoiar o lado instrumental ou o comunicativo da atividade humana? Ou ambos? Será que o usuário conseguirá distinguir entre os artefatos de uso coletivo e os de uso individual?

- Aspectos do aplicativo computacional. A distinção de qual o foco de atenção do método, se na prática de uso ou no conhecimento sobre colapsos, também leva à distinção entre se o método quando for aplicado levará os designers a começarem pelos aspectos intencionais do futuro artefato (a funcionalidade) ou pelos aspectos operacionais (a interface com o usuário). Os métodos tratam diferentemente os aspectos fisicos, de manipulação e orientados a sujeitos/objetos da interface. Flexibilidade, simplicidade e consistência são os conceitos que podem caracterizar estes aspectos.

Segundo Bødker, para elaborar uma nova abordagem para odesign, são necessárias sugestóes mais elaboradas de métodos de design para interfaces com o usuário. No proximo capítulo sấo apresentados alguns dos meiosdeprodução para o design desenvolvidos a partir das questôes tratadas acima. 


\section{Ferramentas e técnicas para 0 design cooperativo}

Um dos maiores prazeres do homem é o de estar completamente envolvido em seu trabalho. $O$ artesáo sabe disso.

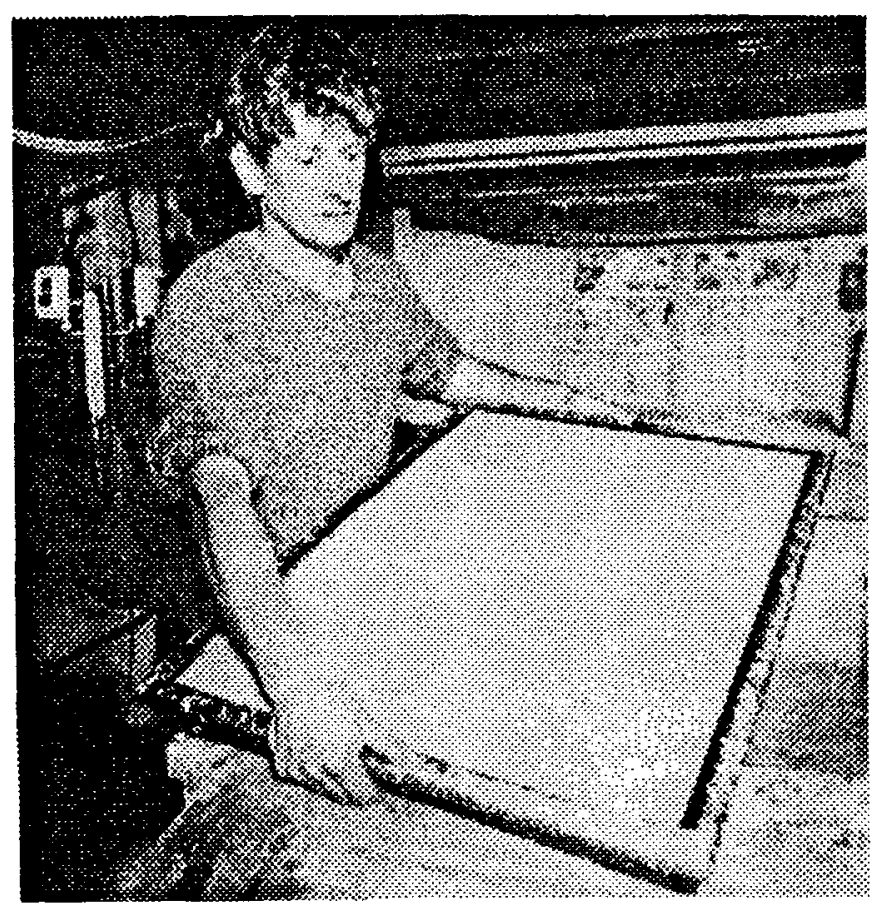


$\mathrm{N}$

os Capítulos 4 e 5 foram apresentados e discutidos os argumentos e idéias de vários autores, que formam o embasamento teórico (e, muitas vezes, prático, no sentido utilizado para "prática") para a aplicação do design cooperativo. Neste caṕtulo são apresentados algumas das ferramentas e técnicas utilizadas por estes pesquisadores para a implantação de projetos a partir destas idéias. Não se trata de um método passo-a-passo; pelo contrário, a preocupação de todo o instrumental se apoia na observação de cada situação onde ocorre um design, para então promover modificações e aprimoramentos nas ferramentas e técnicas que pareçam mais apropriadas. O objetivo é sempre prestar atenção nos aspectos específicos de um determinado processo de design.

Como ficará evidente a partir da próxima seção, estas "ferramentas" e "técnicas" não se parecem com as ferramentas e técnicas com as quais a comunidade da área de computação está acostumada. Basicamente, isto se deve ao fato de que, como o design cooperativo se utiliza de conceitos oriundos de outras áreas de conhecimento, ainda estão para serem construídas as ferramentas e técnicas computacionais que deêm suporte ao uso que os pesquisadores estão dando a este instrumental. Como salientam Greenbaum \& Kyng, "a distância entre as ferramentas e técnicas de implementação e as utilizadas nas diferentes áreas de aplicação ainda é tão grande que não foi possível tentar percorrer esta distância com os usuários, apesar dos trabalhos recentes em programação orientada a objeto poderem melhorar a situação" [72].

O objetivo de se apresentar algumas destas "ferramentas" e "técnicas" é mostrar como, a partir de uma nova maneira de ver e situar o computador, os pesquisadores podem construir os artefatos computacionais de que precisam para desenvolver seu trabalho. A ênfase reside - por serem estas as primeiras tentativas de consolidação do instrumental necessário - nas técnicas que auxiliam o usuário a imaginar o uso futuro do sistema e a testar um "protótipo" em condiçőes semelhantes à que irá encontrar. Segundo a literatura, o desenvolvimento do instrumental de apoio ao design cooperativo está sendo realizado aos poucos, com projetos que datam dos últimos anos. A este respeito veja, por exemplo, as propostas apresentadas por Bødker, Ehn, Knudsen, Kyng \& Madsen [34] de 1992, Floyd, Reisin \& Schmidt [63] de 1989, e Grønbæk, Kyng \& Mogesen [84] de 1993.

\section{Uma estrutura para a "caixa de ferramentas"}

A comunicação é um fator chave nas atividades coletivas como o desenvolvimento de sistemas. As pessoas com diferentes repertórios, educação, treinamento, e papéis organizacionais trocam fatos, opinióes, e visð̃es de maneira a informar, persuadir, e mesmo ofender uns aos outros [110].

Um modelo de comunicação tradicional não dá atenção a estas questỡes em uma situação comunicativa. Quando as pessoas se comunicam, as palavras de quem fala podem ativar uma mudança de estado nos ouvintes. De acordo com Maturana \& Varela, "a comunicação não depende do que é transmitido, mas sim do que acontece com a pessoa que a recebe" [146]. 0 principal critério para uma comunicação bem sucedida a partir desta visão, está relacionado com as pessoas envolvidas, e não a uma espécie de "tubo" que esteja entre elas. Para Kensing \& Munk-Madsen [110], “a comunicação bem sucedida depende da habilidade de estabelecer situações nas quais perturbaçōes mútuas 


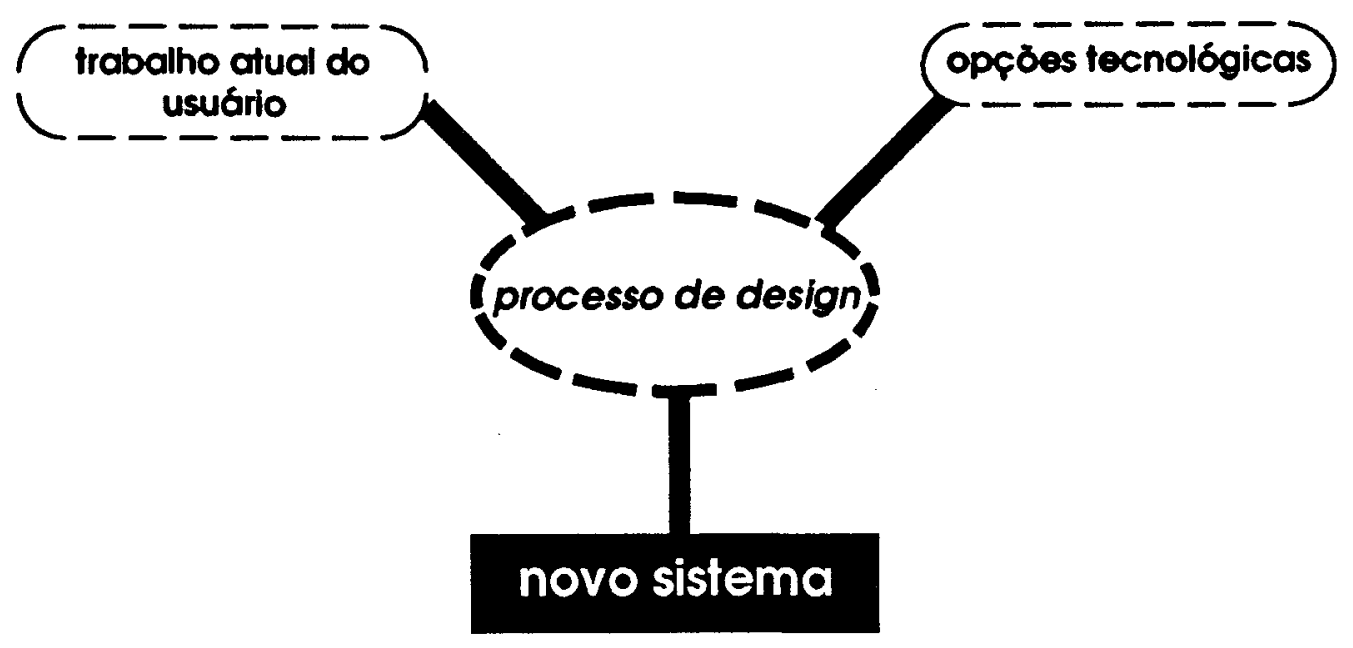

Figura 6.1

Os três dominios de discurso no processo de design (cf. (110)) ativam mudanças no estado das pessoas envolvidas, o que por sua vez leva a uma congruência estrutural (acoplamento social) entre os parceiros de comunicação. (...) A comunicação é criada por pessoas que interagem".

Maturana \& Varela afirmam que o domínio de interação de uma pessoa corresponde ao seu domínio cognitivo (veja Capítulo 4). Isto implica que os tipos de atividades nas quais as pessoas se envolvem delimitam os tipos de conhecimento que são capazes de desenvolver. Técnicas como prototipagem, mapeamento, workshops futuros, e design metafórico são alternativas (à escrita) que criam condições para o desenvolvimento de acoplamento social e, portainto, de comunicação bem sucedida.

A Figura 6.1 ilustra a idéia do design como "construtor-de-pontes", sugerida por Fensing \& Munk-Madsen. Para estes autores, o design está baseado em dois domínios de discurso: 0 trabalho atual dos usuários e as opções tecnológicas. O resultado deste processo leva a um terceiro domínio: um novo (ou apenas modificado) sistema computacional, o que implica em mudanças no conteúdoe na organização do trabalho do usuário.

Baseados nésta distinção; Kensing \& Munk-Madsen propõem cinco teses que modelam a comunicação usuário-equipe de dsenvolvimento [110]:

- Principais domínios de discurso. No design, os principais domínios de discurso são o trabalhoatual do usuário, as opções tecnológicas e o novo sistema computacional (veja Quadro 6.1). O conhecimento destes domínios precisa ser desenvolvido e integrado para que o processo de design seja bem sucedido.

- Áreas que os usuários devem conhecer bem. Os usuários devem ter uma experiência concreta com o seu trabalho.

- Áreas que a equipe de desenvolvimento deve conhecer bem. A equipe de desenvol vimento deve possui conhecimento abstrato e experiência concreta relativa ds opções tecnologicas.

- Conhecimento que deve ser adquirido pelos usuários durante o processo de design. É responsabilidade da equipe de desenvolvimento aplicar ferramentas e técnicas que permitam aos usuários desenvolver estruturas significativas sobre o seu trabalho atual, visões epropostas de design, e experiência concreta com o novo sistema.

- Conhecimento que deve se adquirido pela equipe de desenvolvimento durante oprocesso de design. Éresponsabilidade da equipe de desenvolvimento aplicar ferramentas e técnicas que permitam à equipe desenvolver estruturas significativas sobre o seu trabalho atual, visões e propostas de design, experiência concreta com o trabalho atual dos usuários, e experiência concreta com o novo sistema. 


\section{Trabalho atual do usuório}

\begin{tabular}{ll} 
Conhecimento abstrato & $\begin{array}{l}\text { Estruturas relevantes no } \\
\text { trabalho atual do } \\
\text { usuário (2) }\end{array}$ \\
Experiéncia concrefa & $\begin{array}{l}\text { Experiência concreta } \\
\text { com o trabalho atual } \\
\text { do usuário (1) }\end{array}$ \\
\hline Os números entre parenteses referem-se ao Quadro 0.2.
\end{tabular}

Visoes e propostas de design (5)

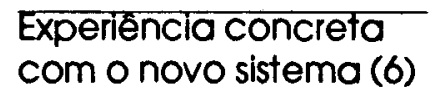

Novo sistema
Opçós fecnológicas

Overview das opçoes tecnológicas (4)

Experiência concreta com as opçoes tecnológicas (3)

Quadro 6.1

Sels áreas de conhecimento para a comunicaçào usuário/equipe de desenvolvimento (cf. (110))

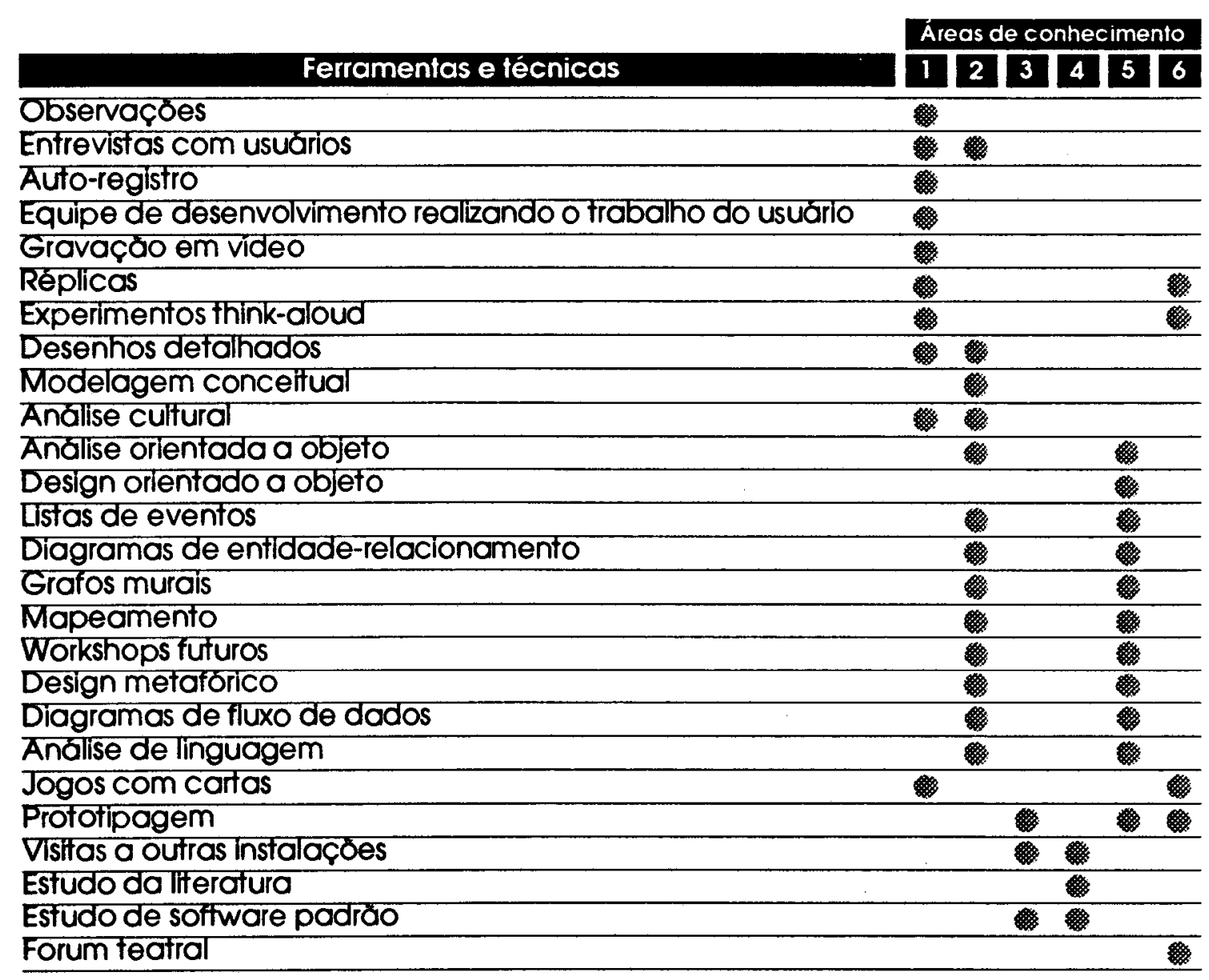

Este modelo pode ser utilizado para definir uma "caixa de ferramentas" com ferramentas e técnicas que facilitem a comunicação entre usuário e equipe de desenvolvimento. $O$ Quadro 6.2 apresenta uma relação de ferramentas e técnicas que podem ser aplicadas para cada área de conhecimento do Quadro 6.1. O Quadro 6.2 acentua as diferenças entre os propositos de cada ferramenta ou técnica, mesmo que elas se adequem a mais de um conhecimento.

O uso de cada uma das ferramentas ou técnicas deve ser adequado às condições particulares do processo de desenvolvimento de um especffico sistema. Em especial, Kensing \& Munk-Madsen recomendam que a experiencia anterior dos usuários com estas ferramentas ou técnicas deve ser levada em consideração. Algumas delas pratica-

\section{Quadro 6.2}

Ferramentas e tecnicas para desenvolvimento do conhecimento (cf. (1 10)). 
mente sempre são usadas com sucesso por usuários e designers. Outras devem fazer parte de um processo mais longo, no qual a equipe de desenvolvimento capta informações em cooperação com os usuários, produz descriçð̃es isoladamente, e finalmente apresenta, discute e altera estas descrições com os usuários. Técnicas como workshops futuros e réplicas pertencem à primeira categoria, enquanto análise orientada a objetoe modelagem conceitual pertencem à segunda.

\section{Gerando visōes: workshops futuros e design metafórico}

A preocupação básica desta técnica e a dar apoio à geração de visões sobre o uso futuro de computadores. Um problema crítico para o design cooperativo é que não existem métodos que auxiliem nesta parte do projeto. As pesquisas empíricas têm mostrado que, enquanto se gasta boa parte dos recursos de um projeto na tarefa de entrevistar usuários sobre a sua forma de trabalhar, poucos recursos são destinados para auxiliar os usuários e os designers a gerarem idéias alternativas sobre como podem vir a ser as situaçס̃es de trabalho no futuro. Algumas das classes de questões relacionadas a este problema são [110]:

- As atividades de desenvol vimento dão pouca ou nehuma atenção às mudanças que ocorrem no conteúdo do trabalho, na autonomia das pessoas, na carga de trabalho, etc. introduzidas pelo novo sistema;

- Os objeti vos do sistema são ambíguos e muitas vezes mal definidos, porque a preocupação básica está relacionada com questões técnicas e econômicas; - Os objetivos do sistema servem para motivar a gerência e a equipe de desenvolvimento, mas não os usuários. O resultado disto é que o sistema soluciona o problema "certo", porque não existe incentivo para a particịpação e a contribuição dos usuários;

- Oprocesso utilizado no desenvolvimento está baseado em atividades de um especialista e tende a usar um modelo de usuário médio, em vez de um individuo caracterizado por suas necessidades;

- Os métodos e as técnicas utilizados estão orientados para o aprimoramento do trabalho dos analistas de sistema e dos programadores; não foram planejados para auxiliar os usuários a tomar parte no processo e construir sistemas de que realmente precisem;

- Em geral, as abordagens conceituais resolvem os problemas errados em vez dos corretos;

- Atitudes ou reações negativas em relação ao sistema constrúdo podem ser encontradas em várias formas de expressão, que vão do ludismo e sabotagem à falta de motivação para usar o sistema da melhor maneira possível.

Estas questões se relacionam à cooperação entre designers e usuários quando estão gerando visões ou quando estão definindo os objetivos do sistema. Kenning \& Madsen argumentam que o processo de criar visões sobre as futuras situações de trabalho deve ser apoiado explicitamente e derivado de umainteração entre as competências dos usuários e dos designers. Para este propósito, a "caixa de ferramentas" dos designers pode ser suplementada por abordagens menos formais do que as que estão atualmente em uso. 
Background. A técnica de workshops futuros foi desenvol vida originalmente para grupos de cidadãos com recursos limitados que queriam tomar parte nos processos de decisão das autoridades de planejamento público (planejamentourbano, projeçðes ambientais, crises de energia, etc.). Kenning propós o emprego desta técnica no desenvolvimento de sistemas, procurando antecipar visø̃es do futuro e discutir como estas visões poderiam ser concretizadas. Os participantes devem partilhar a mesma situação problemática, devem partilhar o desejo de realizar mudanças na situação de acordo com suas visões, e devem partilhar um conjunto de meios para esta mudança.

Como forma de ampliar a perspectiva dos participantes, os facilitadores são encorajados a intervir a nível de conteúdo para introduzir metáforas. O uso de metáforas é muito útil se os participantes se sentem bloqueados ou desenvolvem uma crítica pouco abrangente. Geralmente, um workshop futuro é conduzido por um ou dois facilitadores, com não mais do que vinte participantes. Os facilitadores tentam assegurar uma distribuição equitativa do tempo que os participantes têm para falar, e que todos possam acompanhar as discussões, sugerindo que todos escrevam suas idéias em sentenças curtas em murais (a forma mais comum empregada é a de uma grande folha de papel colocada sobre uma parede).

Kenning \& Madsen acreditam que a metáfora estimula os participantes a olharem para as questões a partir de vários pontos de vista. A essência de uma metáfora está em falar sobre alguma coisa em termos de outra, com as duas coisas sendo diferentes em algum sentido. As metáforas não estão reservadas apenas aos poetas - elas permeiam a vida das pessoas. Portanto, em contraste com as ferramentas de descrição formal de sistemas, as metáforas são uma parte natural da linguagem do cotidiano. Assim, as metáforas podem ser utilizadas como uma ferramenta bem como para a ação das pessoas. As metáforas apoiam a reflexão dos usuários sobre as suas práticas atuais de trabalho e estimulam suas visões sobre maneiras alternativas de trabalho.

Um workshop futuro é dividido em três fases: a de Crítica, a de Fantasia, e a de Implementą̧ão. Basicamente, a fase de Crítica tem como objetivo levantar as questões relativas ds atuais práticas de trabalho; a fase de Fantasia dá aos participantes a liberdade para imaginar "como" o local de trabalhopoderia ser diferente; e a fase de Implementação procura identificar os recursos necessários para mudanças realistas na situação.

Ações iniciais. $O$ grupo começa por desenvolver um repertório comum a partir do qual o workshop pode ser realizado: participar das atividades diárias dos usuários como aprendizes pode auxiliar os designers nesta etapa. Uma atividade em paralelo pode ser a busca por padrões de interação entre os vários grupos de usuários envolvidos, a atenção para a linguagem de trabalho, e ao ambiente fisico do local. Outra atividade pode ser a de visita a locais de trabalho diferentes do dos usuários, onde se pode coletar idéias para as metáforas que estimulam visðes alternativas. Isto acontece em função das implicações sugeridas pelos diversos usos dos computadores observados nas visitas.

Fase de Crítica. No início do workshop futuro, os facilitadores introduzem a técnica aos participantes, e o plano para as atividades conjuntas é discutido e ajustado. Basicamente, a fase de Crítica é como um brainstorming estruturado que tem como foco de atenção os atuais problemas encontrados pelos usuários no trabalho. $O$ primeiro passo pode ser realizar a crítica da próprias práticas de trabalho do grupo: que podem ser formuladas 
como afirmações curtas e escritas em um mural de parede previamente preparado. As intervençð̄es dos participantes são limitadas em termos de duração, e não existe a necessidade de defender ou apresentar argumentos a favor de suas idéias. As afirmações registradas são agrupadas sob temas mais gerais, e os participantes são divididos em grupos pequenos. Cada grupo escolhe um tema (ou conjunto de afirmações) e, através de discussðes, procura reformular a crítica deste tema de maneira concisa a partir do uso atual da tecnologia.

Fase de Fantasia. Para estimular a imaginação dos participantes, a fase de Fantasia começa com duas atividades de "aquecimento". A primeira consiste simplesmente em inverter as afirmaçб̃es da fase de Critica, gerando afirmaçóes positivas. A outra consiste em tentar desenhar como os participantes veêm seu ambiente de trabalho daqui a cinco anos. Novamente longas intervençôes pessoais são desestimuladas, e os facilitadores não evitam nenhuma afirmação considerada mais extrema ou irreal: pede-se que, novamente, o mural seja utilizado para registrar as afirmações. Como na fase anterior, busca-se apenas uma visão geral de conjunto. Cada participante elege, através de voto, as afirmações que mais se aproximem de sua visão do futuro ambiente de trabalho, classificando-as para discussão pelos grupos. Neste ponto, é introduzida a idéia de design metafórico e a discussão procura centrar fogo na definição das metáforas que melhor descrevem o ambiente de trabalho e o proprio trabalho dos usuários.

Fase de Implementação. A fase deimplementação começa com cada grupo apresentando a sua versão do que seria uma "esboço utópico". Cada "utopia" é discutida em uma plenária dós participantes, cujo objetivo é identificar se realmente existem condições para sua implementação. Além disso, édiscutida a necessidade ou possibilidade deestabelecer novas condições sob as quais a "utopia" poderia ser realizada. As sugestões apresentadas são discutidas em grupo e se estabelece uma estratégia comum. $O$ workshop futuro termina com os participantes elaborando um plano detalhado para os primeiros passos da estratégia. $O$ plano consiste de uma lista de tarefas a serem realizadas pelos participantes em um determinado perfodo de tempo.

Bødker, Greenbaum \& King acreditam que, pela "experiência, (...) existe uma necessidade de estabelecer workshops ad hoc com os usuários para fornecer maneiras de aperfeiçoar sua compreensão do processo de design. Para limitar os efeitos de poder e recursos desbalanceados neste processo, sugerimos que os workshops sejam realizados com pessoas de níveis semelhantes dentro de uma organizaçăo" [35].

Workshop futuro e design metafórico fornecem um quadro de referência para dar o devido destaque as mudanças no ambiente de trabalho e na organização. Jogar com as metáforas nas fases de Crítica e de Fantasia permite que os usuários expressem mais facilmente o que gostam e o que não gostam. Kensing \& Munk-Madsen acreditam que o papel de facilitadores "fornece uma idéia da 'alma' da organização. (...) Isto auxilia a melhor compreender como os usuários imaginam o futuro de seu ambiente de trabalho. Isto e fundamental para a posterior conceitualização do sistema, e é um tipo de compreensão que não pode ser obtido através dos métodos tradicionais". 


\section{Fazendo réplicas ou colocando as măos no futuro}

Para auxiliar na atividade de design de imaginar o futuro, a equipe de desenvolvimento pode se valer da utilização de réplicas (mock-ups) dos equipamentos que poderão fazer parte do sistema. Este tipo de réplicas pode ser construído de maneira econômica, evitando que ocorra um grande investimento em equipamento antes do sistema estar pronto. Ehn \& Kyng descrevem o uso de papelão, projetores de slides, telas, caixas, madeira, e outros produtos baratos na construção de réplicas, com o objetivo de permitir que os usuários tenham uma experiencia concreta com o futuro sistema. Os exemplos apresentados por estes autores vão de "computadores de papelão" até "réplicas de computadores" [59].

Por que réplicas? Ehn \& Kyng sugerem que o design de artefatos como réplicas pode ser muito útil nos primeiros estágios do processo de design. Estas réplicas encorajam o ativo envol vimento dos usuários. "Eles auxiliam atualmente os usuários e designers a transcender os limites da realidade e imaginar o impossivel".

Mas por que estas réplicas são úteis, apesar de praticamente não terem nenhuma funcionalidade e do fato de serem um tipo de simulacro? As respostas, segundo Ehn \& Kyng, incluem:

- as réplicas encorajam os usuários a "porem a mão experimentalmente", nascendo dar um envolvimento que vai além da reflexão a posteriori permitidas pelas descrições de sistemas tradicionais;

- as réplicas são compreensiveis, não existindo então a confusão entre a simulação e a "coisa real", e todos possuem a competência mínima para modificá-las;

- as réplicas são baratas, permitindo que sejam feltos vários experimentos sem grandes investimentos em equipamento, compromissos, tempo, e outros recursos;

- é divertido trabalhar com as réplicas.

As réplicas têm um papel importante na sociedade: as crianças sempre brincaram com réplicas como bonecas, carros, etc. É diff́cil imaginar a vida humana sem esse tipo de brincadeira. O uso proposto por Ehn \& Kyng é semelhante a estas brincadeiras, mas, segundo estes autores, a maior inspiração veio do design industrial, que se utiliza de réplicas há décadas, principalmente no que se refere ao design ergonômico.

Existem diversos exemplos da utilização de réplicas por designers industriais. Eles foram capazes de simular o trabalho futuro: o fluxo de encargos, as tarefas de cada operador, incluindo a carga de trabalho, e a possibilidade de auxílio mútuo quando ocorrem estrangulamentos na produção. A partir desta simulaçóes geralmente são feitos aprimoramentos, incluindo sugestðes para reduzir o desconforto físico e para novas formas de cooperação.

O uso de réplicas proposto por Ehn \& Kyng é similar ao uso industrial, mas, no entanto, concentra sua atenção em construir jogos para a imaginação de futuros processos de trabalho. Em contraste com os designers industriais, o foco maior está na funcionalidade do hardware e do software dos futuros artefatos em vez de nos aspectos ergonômicos. 
Jogos de linguagem. Geralmente as pessoas são guiadas pelo conceito "o que uma foto descreve é determinado pelo seu uso" [59]. Para os pesquisadores formados em uma tradição de ciências exatas, onde a descrição de um sistema normalmente é vista como um tipo de imagem especular da realidade, esta afirmação pode parecer chocante. No entanto, esta e a posição de Ludwig Wittgenstein em Philosophical Investigations (citado em [59] e [225]). Como filosofo, Wittgenstein ficou conhecido por escrever uma tese de doutorado onde mostrava como se pode mapear a realidade com uma linguagem precisa (1923). Então ele passou o resto da vida tentando convencer seus contemporâneos de que estava errado - existe muito mais na linguagem e interação humanas do que aquilo que pode ser escrito, e que, na verdade, linguagem é ação. Em vez de se preocupar com imagens especulares da realidade, as pessoas devem pensar nos jogos de linguagem que as pessoas jogam - como são capazes de participar de atividades humanas porque aprenderam a agir de acordo com as regras não escritas dessa atividade.

A razão para que, nas atividades de design, os participantes possam usar corretamente as réplicas está relacionada com o fato de que o jogo de linguagem do design tem uma semelhança com outros jogos de linguagem aprendidos. Entretanto, uma caixa de papelão não se transforma em uma impressora a laser por si só. De fato, um dos grandes desafios para os designers é o de criar um jogo de linguagem que faça sentido para todos os participantes. Assim, o emprego de réplicas durante o design so é eficiente quando os jogos de linguagem fazem sentido para todos os participantes. Nestes jogos, as réplicas fazem o papel de lembretes que apontam para a experiência de usar o artefato. Em vez de produzir argumentos racionais para apoiar um determinado ponto de vista que explica a existência de um colapso, há a possibilidade de repetir a sequiência de operações que levaram a um colapso. Então, pode-se avaliar tanto a situação quanto os passos que a produziram, as alternativas para superar o problema, e mesmo os argumentos racionais a favor de um ponto de vista.

Resumindo, réplicas se tornam úteis quando fazem sentido para os participantes de um determinado jogo de linguagem de design, não porque elas espelham "coisas reais", mas sim por permitirem interação e reflexão (veja [58]).

Um novo papel para o designer é preparar a cena e permitir que usuáriose designers desenvolvam e participem de um mesmo jogo de linguagem de design. Este é um jogo que tem que ser similar aos jogos que os usuários e os designers estão acostumados; um jogo de linguagem que é construído socialmente pelos participantes.

Ao contrário de artefatos lingǘrticos como diagramas de fluxo e documentos do sistema, as réplicas permitem que o usuário "ponha a mão na massa". Como destacam Ehn \& Kyng, "como designers produzimos um número sem fim de descrições de sistemas detalhadas e metodologicamente corretas. Só existe um problema. Os usuários não conseguem entender nossas descrições. As descriç̋̃es não lembram aos usuários nenhuma situaç̃o de trabalho familiar. Não existe nenhum papel para os usuários durante o uso destes artefatos de design. A experiência de usar estas descrições não se relaciona com suas experiências profissionais" [59].

Além do computador de cartão. A idéia de "por a mão no futuro" em oposição a "colocar os olhos em uma descrição do sistema" foi o foco dos parágrafos anteriores. As réplicas foram discutidas em termos dos materiais mais simples, como papelão e papel, mas obviamente existem outras maneiras para estas atividades, principalmente protótipos 
baseados em computadores. Estes protótipos serão apresentados e discutidos na próxima seção. Mas, o quepode acontecer na fronteira entre "computadores de papelão" e os prototipos "reais"?

Como primeiro passo, pode-se considerar algumas possibilidades que são mais complexas, apesar de não serem baseadas em computadores. Dependendo da disponibilidade e das habilidades do grupo de design, estas possibilidades podem incluir projetores de slides e de sobreposição, gravadores e videos. Estas artefatos são familiares para os participantes do grupo, no sentido de que podem distinguir facilmente quando ocorrem disfunções nos artefatos ou no design. Ao mesmo tempo que fornecemalgumas funcionalidades queestão além das possibilidades do papelão, tornam possível um look \& feel mais próximo do que será apresentado pelo futuro produto. As dificuldades, entretanto, aparecem em função deste tipo de réplica exigir mais habilidades e recursos, tanto em tempo como em dinheito, além de serem mais difíceis de modificar.

Nesta fronteira entre réplicas e protótipos, as distinções entre os dois não são fáceis de identificar. De fato, Ehn \& Kyng não veêm as diferenças entre uma réplica e um protótipo como uma questão de se o computador está sendo usado ou não. Com as réplicas - usando-se computadores ou não - o o foco de atenção está no apoio para imaginação de maneira geral. Utilizando uma analogia com a produção de filmes, este tipo de antevisão foi chamado de prototipagem via storyboard (veja seção com este título neste capitulo). Segundo Ehn \& Kyng - citando o produtor do storyboard do filme Uma Cilada para Roger Rabbit, Marty Kline -, "um storyboard é uma forma de ver o filme sem gastar muito dinheiro... Não é o filme pronto, mas representa uma primeira tentativa de olhar para ele".

Passando de réplicas e prototipagem via storyboards para protótipos reais, a aten-ção se desloca para as possibilidades de demonstrar a real funcionalidade de um design. Prototipos computacionais diferem do uso de computadores nas réplicas de duas maneiras. Muitas vezes, os computadores são utilizados nas réplicas com propositos diferentes daqueles pretendidos pelo futuro sistema computacional. Os computadores não têm nenhuma posição privilegiada em relação ao papel ou ao papelão. Eles são utilizados apenas com base no quão bem podem contribuir para criar a ilusão de uso do futuro sistema. Segundo Ehn \& Kyng, "olhamos primeiro para o uso de computadores como uma forma de aprimorar a eficiência na construção e modificação de réplicas. Somente então olhamos para maneiras de explorar as limitaçðes tecnológicas via computadores. Por último, discutimos a questão de obter mais funcionalidade" [59].

\section{Prototipagem cooperativa}

Bødker \& Grønbæk encontram fortes argumentos para um envolvimento mais ativo e direto dos usuários no design de sistemas computacionais, para que possam experimentar como serão as funções do sistema na situação de uso [37]. Para estes autores, "experimentar não significa ler uma descrição do sistema, nem assistir a uma demonstração. Achamos que a prototipagem pode ser muito útil na descoberta de aspectos inarticulados [veja Capítulo 5] do trabalho do usuário e contribuir para o design de ferramentas aprimoradas. Ao experimentar o 'futuro', podem ocorrer colapsos que obrigam a mudanças no protótipo e, eventualmente, mudanças no futuro sistema computacional. Em relação as réplicas, a principal vantagem da prototipagem é apresentar melhor os aspectos dinâmicos do futuro aplicativo" [37]. 
Abordagens para prototipagem. Nos últimos anos foi proposta uma rica variedade de abordagens para a prototipagem. Todas fornecem facilidades para que o usuário "ponha a mão na massa" antes do aplicativo final ser construído; e, mesmo assim, as abordagens não sãoutilizadas desta forma. Grønbæk faz uma crítica de trêscategorias da prototipagem: as abordagens o protótipo se transforma no sistema; especificą̧ões executáveis; e exploratória [83].

A abordagem oprototipo se transforma no sistema domina a prática de desenvolvimento de sistemas e a literatura atuais. Ela complementa a tradicional especificação de requisitos com um protótipo dos aspectos da interface com o usuário antes que a implementação comece, principalmente para os usuários ajustarem detalhes do sistema. A partir de estudos empíricos, Grønbæk conclui que "estes protótipos são usados principalmente para demonstrar características do sistema, e não para permitir que os usuários experimentem ativamente o sistema" [83].

O principal objetivo da abordagem de especificações executáveis é obter uma completa especificação formal do que as partes do futuro sistema devem fazer. As especificações são feitas em uma linguagem formal executável, com a intenção de que um programa, e portanto um protótipo, possa ser gerado automaticamente a partir da especificação. Apesar dos usuáriose designers, em teoria, poderem avaliar a especificação através da avaliação do protótipo, isto raramente é feito. A linguagem de especificação geralmente não serve como um meio de comunicação com os usuários e já foi demonstrado empiricamente que o esforço exigido para gerar uma especificação formal é semelhante ao esforço de programar o sistema da maneira tradicional.

$\mathrm{Na}$ abordagem exploratória, réplicas, simulações e protótipos "descartáveis" são desenvolvidos a partir de várias ferramentas. A meta desta abordagem é construir esquemas "rápidos" do aplicativo computacional de maneira a esclarecer os requisitos para um novo sistema. Existe, na literatura, a descrição de um certo número de casos onde ocorreu o envol vimento do usuário na avaliação de protótipos, mas não existem muitos exemplos de envolvimento ativo do usuário no design e na modificação dos protótipos, de maneira a influenciar criativamente o futuro sistema. Os protótipos nestes exemplos servem principalmente como especificações substitutas para o aplicativoe para propagar idéias para as atividades de design [37].

Estimulando a participação e a criatividade. As abordagens tradicionais de prototipagem geralmente tomam a perspectiva dos designers e engenheiros de software, dando pouca ou nenhuma atenção ao envolvimento dos usuários no processo de design. A abordagem introduzida por Grønbæk [83] e Bødker \& Grønbæk [37] — denominada prototipagem cooperativa - tem suas rázes na abordagem exploratória, mas procura demonstrar que a prototipagem pode ser uma atividade cooperativa entre usuários e designers.

O objetivo da abordagem é, ao estabelecer um processo de design onde designers e usuários participem ativamente, permitir que os usuários experimentem uma situação semelhante à de seu trabalho com o futuro sistema: as habilidades atuais dos usuários devem ser colocadas em contato com novas possibilidades tecnologicas. Isto pode ser feito, de acordo com Bødker e Grønbæk, em uma situação futura de trabalho simulada ou, ainda melhor, em uma situação real de uso. "Quando ocorre um colapso na situação de uso simulada, usuários e designers podem analisar a situação e discutir se o colapso 


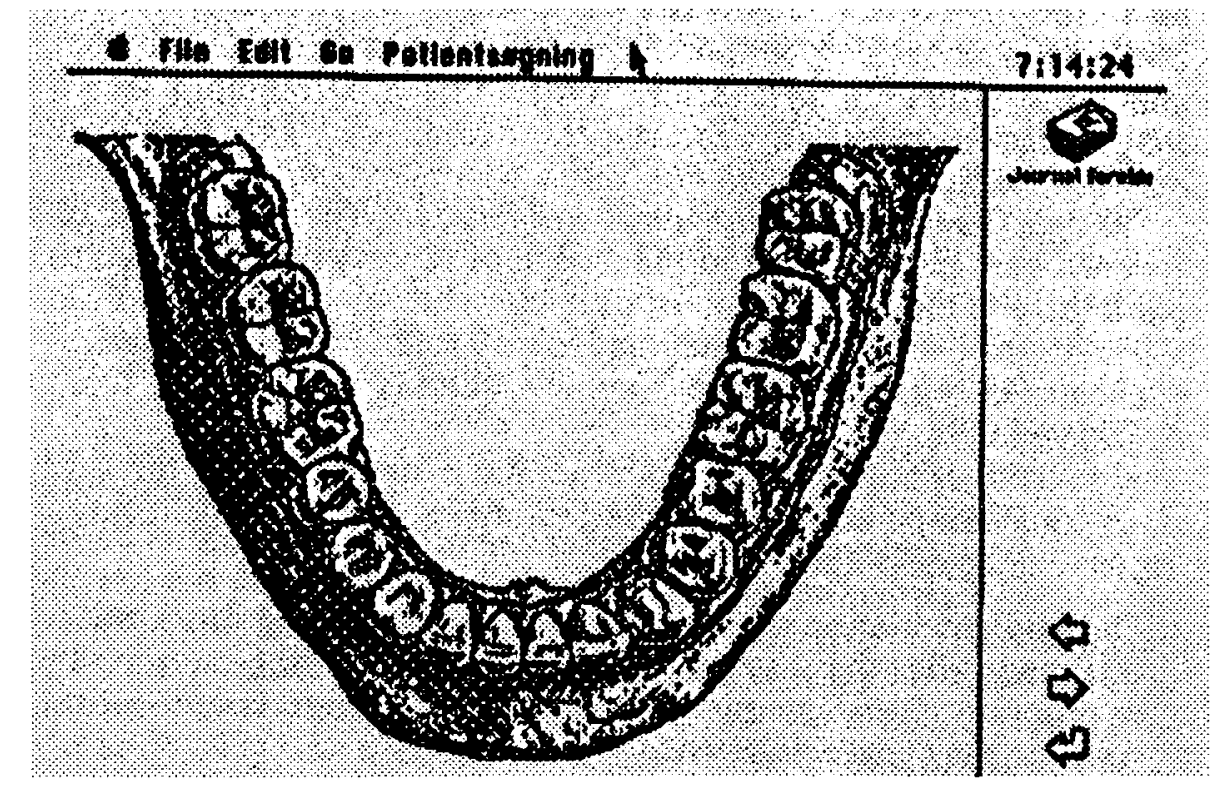

ocorreu por causa da falta de treinamento, de uma solução incompleta ou ruim de design, ou por alguma outra razão. Os colapsos originados por soluçőes ruins ou incompletas de design podem ser rapidamente aprimorados, reestabelecendo a avaliação fluente do protótipo" [37].

Para experimentar completamente o protótipo, os usuários precisam ter controle de seu uso por um bom período de tempo, e devem poder usá-lo em uma situação de trabalho. O papel do designer inclui a antecipação da situação de uso e a construção/limpeza dos protótipos durante as várias sessões de prototipagem. A prototipagem cooperativa, segundo Bødker \& Grønbæk, deve ser realizada por um pequeno grupo de designers e usuários com acesso a ferramentas computacionais flexíveis para o rápido desenvolvimento e modificação dos protótipos.

Exemplo. Um exemplo de aplicação da prototipagem cooperativa é ode desenvolvimento de uma interface para um sistema de controle em clínicas odontológicas [36]. Os usuários finais eram assistentes em clínicas das escolas públicas da Dinamarca. O propósito destas clínicas é manter check-ups regulares e tratamento para as crianças das escolas. As assistentes possufam pouca ou nenhuma experiência com computadores.

$O$ processo de prototipagem foi conduzido de maneira a que as assistentes aprendessem sobre tecnologia computacional - sobre design de sistemas em geral e design para clínicas odontologicas em particular. Um protótipo inicial foi preparado - com relatóriose dados fictícios - em HyperCard. As sessões iniciaram com uma demonstração do protótipo; foi explicado que o protótipo fora construído em uma ferramenta flexfvel o suficiente para facilmente permitir alteraçóes, e foi pedido que as participantes apresentassem sugestð̃es para o aprimoramento da interface. A designer tentou se manter afastada de maneira a permitir que as assistentes experimentassem por si mesmas o protótipo e imaginar que estivessem realizando as tarefas diárias de uma clínica. A designer só interviu no processo quando ocorria uma situação de colapso na qual as assistentes tinham problemas ou sugestões para aprimoramentos.

Alguns exemplos de aprimoramentos que resultaram da cooperação com as assistentes na sessão de prototipagem são:

- modificação da representação dos dentes - a imagem inicialmente usada estava "de cabeça para baixo" (veja Figura 6.2);

- representações alternativas paraos tratamentos dentários - as assistentes solicitaram uma representação direta na imagem;

- design do layout dos relatórios - os relatórios iniciais foram modificados e adaptados.
Figura 6.2

Representaçōo direta de dentes em um protótipo de controle odontologico (cf. (37)). 
As modificações foram feitas através da manipulação direta e a experiência geral foi de que as assistentes se entusiasmaram com a possibilidade de auxiliar nas alterações. Outros aprimoramentos incluíram modificação nos scripts dos buttons usados, criação de um comando de busca para os relatórios, implementação de um menu para busca de fichas de clientes, acréscimo de outras possibilidades de relatórios.

Liçōes. Bødker \& Grønbæk relatam que, a partir do protótipo, foram tiradas algumas conclusø̃es [37]:

- o uso de cartóes com representação direta dos dentes parecia promissor;

- as assistentes precisavam de uma representação geral dos tratamentos efetuados, o que poderia ser conseguido com a marcação nos dentes associados a links para cartões com informaç̃̃es mais detalhadas.

No que se refere à utilização da técnica, Bødker \& Grønbæk concluem que:

- a maior mudança foi a de interromper o processo, modificar o protótipo, enquanto as assistentes criticavam alguma parte dele, e então reiniciar o processo de avaliação;

- o uso de um prototipo que fornecia cartões e imagens de dentes permitiu que as assistentes formulassem requisitos e necessidades muito específicas para um futuro aplicativo computacional;

- a partir da ferramenta de prototipagem que estava sendo utilizada, foram detectadas duas fontes de colapsos indesejáveis na situação de design: (1) alcançar os limites das possibilidades da manipulação direta; e (2) fazer modificações que exijam uma grande reestruturação do protótipo;

- o estudo mostra que não há necessidade de fornecer um protótipo que simule completamente a funcionalidade do sistema.

O que parece mais importante, no entanto, é que "as experiências mostram que é possível para um grupo de trabalhadores, quando for dada a oportunidade, chegar a contribuiçôes construtivas e criativas para o design de seus proprios sistemas computacionais. As discussões quase sempre estiveram centradas no protótipo em avaliação e não nas questơes técnicas" [37].

De outras experiências, Bødker \& Grønbæk destacam também que "o uso de protótipos assim como de sistemas já existentes como sugestões alternativas para o futuro, permite que os usuários participantes formulem melhor suas sugestões. Não é necessário que se chegue a um consenso sobre a compreensão do problema desde que algumas das soluções encontradas façam todos se sentir confortáveis com o uso futuro" [37].

Como utilizar a prototipagem cooperativa. Para que um proceso de prototipagem cooperativa funcione é necessário para o grupo de trabalho que se estabeleça uma compreensão mútua das metas do processo, do status dos produtos intermediários desenvolvidos, e do papel da prototipagem no processo de design como um todo.

Bødker \& Grønbæk sugerem alguns passos para que os designers possam utilizar a prototipagem cooperativa:

- a seleção e formação do grupo de trabalho com a escolha de usuários para as atividades conjuntas é muito importante e, muitas vezes, está fora do alcance dos designers; mesmo assim, algumas formas, por exemplo, de sele- 
cionar os usuários podem ser utilizadas: os administradores de segundo escalăo possuem uma visão geral do domínio de trabalho; os participantes que constituem exemplos estatisticamente representativos; representantes eleitos pelos usuários; empregados com experiencia no uso de computadores; os trabalhadores mais habilidosos entre os futuros usuários; e os mais entusiasmados entre os futuros usuários. Qual é o melhor critério? Diff́cil dizer: vai depender da situação de uso especffica. O importante é estabelecer um grupo de trabalho conjunto com uma boa representação de usuários competentes.

- três questões se revestem de importância ao se estabelecer as sessões de prototipagem:(1) a "lição de casa" dos designers deve ser feita completamente, para que a sessão possa ocorrer sem problemas; (2) o designer deve saber quando deixar para depois a implementação de alguma alteração no prototipo equando isto pode ser feito durante a propria sessão; $\mathrm{e}$ (3) os designers devem preparar tudo o que for necessário para que os usuários tenham uma experiência a mais próxima possivel da futura situação de uso.

- as atividades de prototipagem sempre podem ser complementadas com réplicas mais flexíveis e mesmo com as tradicionais descrições para cobrir aspectos do futuro aplicativo que não podem ser facilmente tratados pelos protótipos.

- deve-se manter em mente que os usuários são a chave para o design de um sistema utilizável e os designers são a chave para propagar as demandas dos usuários durante o design técnico do sistema. O delicado equilíbrio pode bem ser o design de um aplicativo que seja útil para os usuários e de alta qualidade para o ponto de vista técnico. A comunicação das idéias para o design que melhor podem ser aproveitadas ocorre quando os problemas são explicados dentro dos jogos de linguagem familares aos usuários.

- os protótipos direcionam as expectativas tanto dos usuários quanto dos designers, de tal forma que pode ocorrer uma cegueira em relação a outras soluções para os problemas que estão sendo tratados. É necessário criar uma consciência de que os protótipos são apenas rascunhos, podem ser descartados, são temporários, e não possuem a mesma funcionalidade do futuro sistema. - os maiores problemas não são puramente técnicos, mas estão apoiados no acoplamento entre soluções técnicas e trabalho, organização do trabalho, e estrutura de poder no ambiente de trabalho. Para manter o foco de atenção neste acoplamento,é necessário o uso de outras técnicas além daprototipagem. Oideale se evitar um foco de atenção exagerado nas questð̃es computacionais. - vários autores já destacaram que os erros mais caros no desenvolvimento de um sistema ocorrem nas fases iniciais. Ao mesmo tempo, os recursos gastos nestas fases formam a menor partedos gastos totais. Portanto, é importante que se consiga garantir a participação dos usuários no grupo de trabalho; para se envolverem totalmente, devem ser liberados de parte do trabalho diário para evitar carga dobrada.

Para Bødker \& Grønbæk,"a prototipagem cooperativa pode ser usada para melhorar a qualidade de um sistema computacional visto a partir da ótica dos usuários; isto é, os usuários podem obter um sistema melhor adaptado às suas necessidades e assim 
aprimorar a qualidade de seu trabalho.(...) [No entanto], nem os designers nem os usuários podem obter um conhecimento completo das possibilidades para fornecer suporte computacional para um domínio de aplicação; 0 design é um processo em andamento. Assim, a prototipagem cooperativa não deve ser vista como uma abordagem para produzir o aplicativo perfeito. Ao contrário, deve ser vista como um dos passos iniciais para um processo de desenvolvimento em andamento no qual o aplicativoé ampliado e adaptado em conjunto com as necessidades que se modificam" [37].

\section{Prototipagem via storyboard}

A prototipagem via storyboard é uma variante da escola "planeje de maneira a fazer a coisa certa"; pode ser definida como "uma técnica criada para gerar consenso a partir de um conceito de sistemas tangivel e interativo. Ela permite que os usuários participem do processo de validação de requisitos, e fornece um histórico do processo de análise de requisitos. A apresentação de um storyboard interativo para usuários e administradores tem a intenção de provocar comentários e críticas" [138]. Como na produção de um filme, ouso de storyboards no desenvolvimento de um sistema computacional é uma maneira de "rascunhar" o futuro sistema logo no início do processo. Para Madsen \& Aiken, "a equipe de desenvolvimento, em um esforço para verificar os requisitos, geralmente utiliza réplicas não-funcionais - uma tecnologia datada da década de 30para apresentar ao usuário uma visão orientada-a-tarefa do sistema proposto. $O$ conceito de iteração como processo de descoberta é a chave para a prototipagem: cada iteração sucessiva traz o protótipo um passo mais próximo da correta representação das necessidades do usuário" [138].

Um dos principais problemas é a demora associada à produção da próxima versão do storyboard. Um espaço muito grande de tempo entre as sessões de avaliação dos usuários leva a uma perda no aprendizado mútuo e pode introduzir erros e perpetuar omissões no processo de desenvolvimento.

Para reduzir este delay Madsen \& Aiken descrevem o uso desta abordagem através da ferramenta CISP (Cooperative Interactive Storyboard Prototyping), que visa reduzir os intervalos de tempo associados com a produção da "proxima iteração" do storyboard. Além disso, CISP procura oferecer condições para avaliação dos protótipos sob circunstâncias realistas e modificação em tempo real destes protótipos. "A intenção não é apenas de acelerar o processo de design, mas de criar uma situação onde os designers possam responder aos pedidos dos usuários em tempo real" [138].

Construindo blocos. A ferramenta CISP é uma extensão do HyperCard que faz parte da pesquisa realizada no Laboratorio de Tecnologias de Hipermídia da Georgia Mason University, onde se busca desenvolver tecnologias de hipermídia para a fase de análise na tomada de decisões e solução de problemas.

Segundo Madsen \& Aiken, quanto mais os usuários puderem trabalhar com objetos familiares, mais serão capazes de participarem do processo de desenvolvimento. CISP apoia o desenvolvimento cooperativo de interface permitindo que o usuário combine blocos construtivos montados a partir de objetos especificos do domínio do aplicativo (veja Figura 6.3). Utilizando apenas uma seleção de menu, CISP oferece a possibilidade de se alterar qualquer elemento da interface. Usuários e designers podem avaliar rapidamente a eficiência de diferentes combinaçðes dos blocos durante uma sessão. 


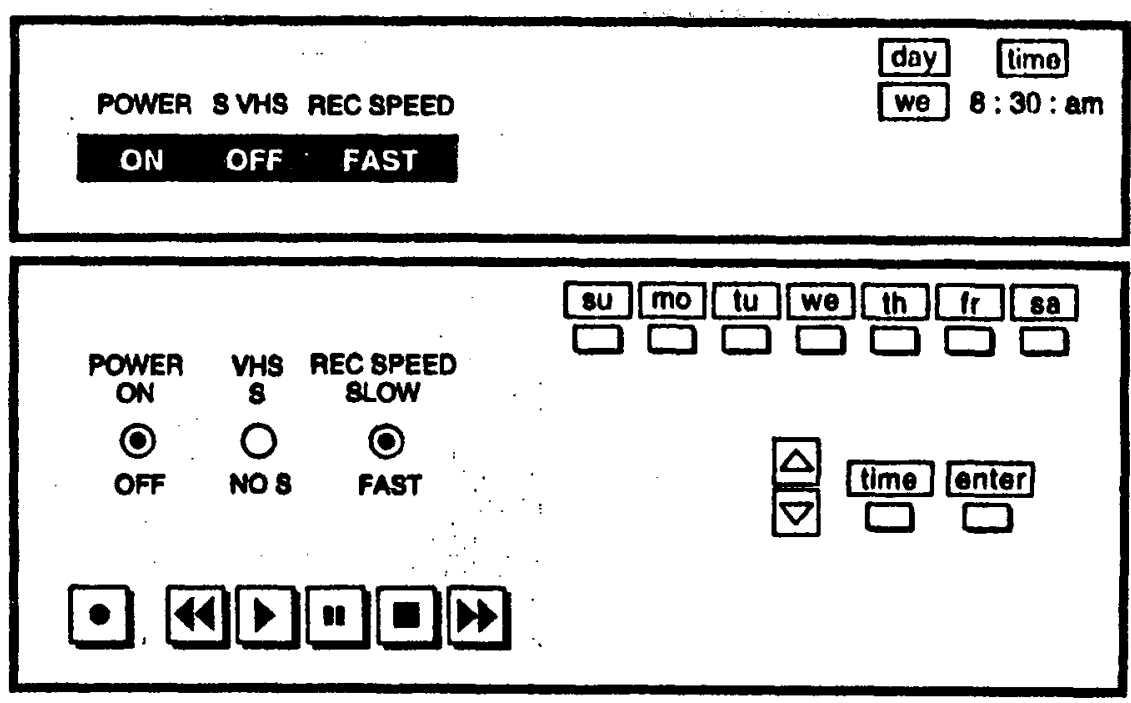

Técnica CISP. Além das facilidades para iteração, a abordagem adotada pela CISP para o desenvol vimento de interfaces envolve cinco técnicas especificas que têm como função complementar outras estratégias de prototipagem:

1. Look \& feel realista. Todas as ações do usuário podem ser gravadas - via computador e/ou vídeo - guardadas e repetidas para posterior discussão por usuários e designers.

2. Modificação interativa. Comoos blocos construtivos podem ser facilmente copiados e deslocados como um simples objeto, os usuários e designers podem modificar interativa e cooperativamente o storyboard em tempo real. 3. Geração e comparação de alternativas de design. Uma parte essencial da prototipagem é a possibilidade de avaliar diversas versð̃es de soluções para o mesmo problema de design. Outra possibilidade é a de se ter um auditoria de todas as sessões, o que permite descrever como as soluçð̃es foram criadas. 4. Criação de familias de sistemas. CISP facilita a criação de famflias de sistemas, os quais partilham vários dos componentes centrais mas diferem significativamente em outros aspectos. Isto pode ser obtido construindo-se o storyboard para as partes comunse introduzindo variaçóes. Outra possibilidade e a criação de um sistema que precisa ser adequado a cada usuário, para atender a necessidades locais.

5. Interfaces/prototipos realistas. Os usuários interagem com prototipos realistas e podem perceber como o sistema está sendo desenvolvido.

Promessas e problemas. Apesar do esforço inicial para desenvolver os blocos construtivos especfficos do domínio de aplicação, a abordagem adotada pela ferramenta CISP permite um ganho significativo ao se criar protótipos para interfaces. A redução no esforço é particularmente importante quando se trata de uma famflia de interfaces. Segundo Madsen \& Aiken, os usuários e designers apreciaram muito a possibilidade de repassar as sessð̃es para discussão e avaliação.

Oprincipal problema relatado pelos autoresestá relacionadocomodesenvolvimento da ferramenta a partir de um programa existente que, apesar de fornecer várias das funcionalidades desejadas, ainda sofre de deficiencias em relação ao uso de programação orientada a objeto e a performance em prototipos maiores e mais complicados.
Flgura 6.3

Blocos construtlvos CISP para uma interface de video (ct. (138)). 


\section{Cooperação faz sentido}

Realidade virtual... A última interface da humanidade?

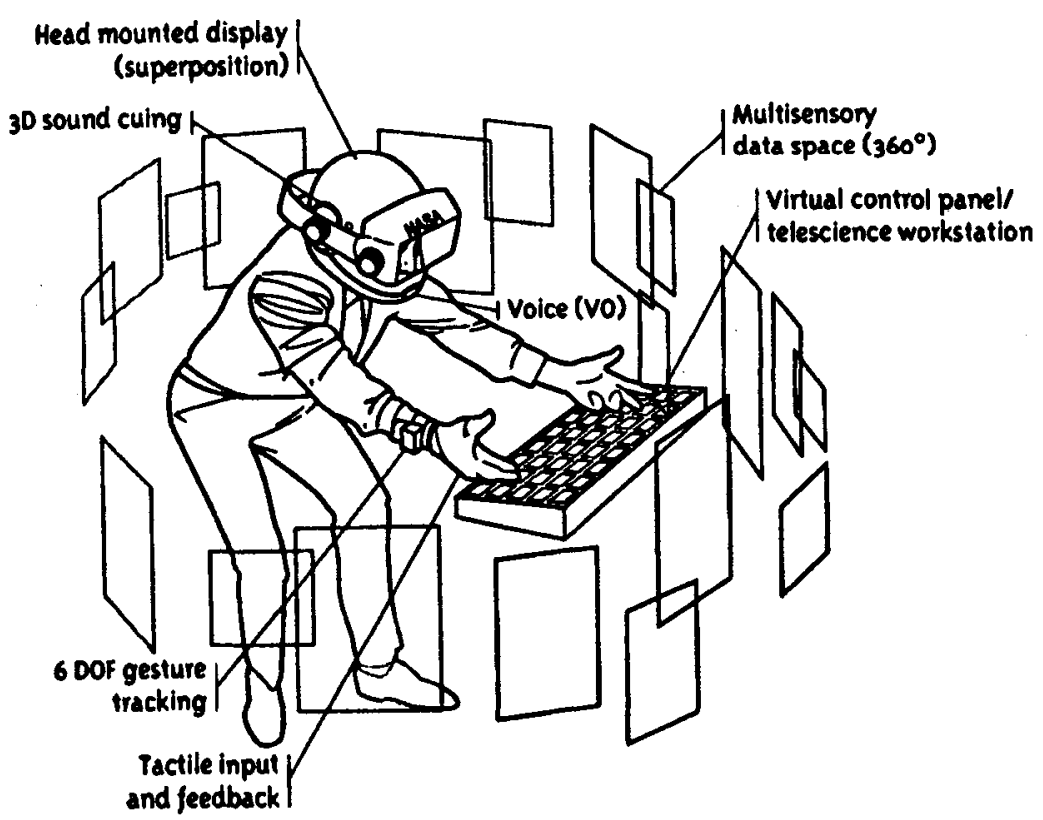


A partir da nova ordem organizacional — nela incluindo partidos, escolas, empresas, organizações civis, e a sociedade como um todo - provocada pela tecnologia da informação emergente, é possfvel prever que a área das Ciências da Computação e, em particular, a de HCI, irão passar por mudanças fundamentais. As implicações destas mudanças apontam para uma alteração radical na forma como a humanidade vê a construção da realidade onde vive.

A ênfase no tratamento da informação, não como simples processamento dedados, mas como um degrau para o processamento do conhecimento, está gerando uma enxurrada de inovações que afetam substancialmente a Aldeia Global. Economia, Comunicação e Educação são, a princípio, algumas das áreas mais afetadas ([151] e [221]).

Para a Computação, o impacto destas inovações - muitas delas geradas dentro da propria área - está pressionando as equipes de desenvolvimento a construirem equipamentos e softwares mais eficientes, de melhor qualidade, e mais poderosos. Particularmente no que se refere a software, está ocorrendo uma mudança nos pontos de vista tradicionais adotados pela área. A figura do "usuário" deixou de ser apenas um modelo térico - ou, quando muito, um modelo de marketing -, para se transformar em uma das bandeiras das novas metodologias de desenvol vimento que, contudo, ainda se mantém presas a tradições com mais de um século de idade [7].

Primeiro, surgiu a preocupação de "centrar" todo o desenvolvimento na figura do usuário. Nos últimos anos, principalmente na Escandinávia, os problemas oriundos dessa primeira abordagem começaram a ser analisados sob a luz de uma ótica diferente da adotada até então. Baseados em uma tradição de democracia e participação do cidadão em todos os níveis da sociedade, os parses escandinavos apoiaram, também na área de informática, a criação de caminhos para resolver estes problemas. O resultado - teórico e prático - está começando a produzir seus efeitos: um número razoável de projetos já foram ou estão sendo executados, foram realizadas duas conferências internacionais específicas sobre o tema, e o número de pesquisadores e empresas que se utilizam das idéias e conceitos do design cooperativo cresce a cada ano (veja [44] para um levantamento pormenorizado).

\section{(Auło) Crítica do design cooperativo}

Em virtude de sua "pouca idade", os pesquisadores que estão tentando estruturar o design cooperativo apontam as principais questões com as quais estão se debatendo [73]:

- uma base teórica muito diversificada, aliada à inexperiência em expressá-

la na prática;

- a falta de relacionamentos cooperativos com potenciais usuários;

- a falta de "bons produtos" e de recomendações para transformar bons designs em bons produtos/sistemas;

- a falta de projetos práticos reais para testar idéias sobre design cooperativo.

Por outro lado, a pesquisa teórica e prática levada a efeito nos últimos anos serviu para sedimentar alguns dos principais conceitose nortear o caminhopara a determinação das dificuldades a serem estudadas:

- Design cooperativo. Os usuários, assim como os designers, possuem conhecimento e habilidades que são fundamentais para o design de aplicativos 
computacionais úteis; portanto, o design precisa ser organizado como uma atividade cooperativa entre usuários e designers.

- Familiaridade. Para permitir que ambos os grupos possam realmente contribuir de maneira criativa, o design precisa estar baseado em situaçóes que possuam uma familiaridade com a experiência de trabalho anterior tanto dos usuários quanto dos designers.

- Prática de trabalho. Construir um aplicativo computacional e introduzi-lo no ambiente de trabalho modificará a prática de trabalho. Assim, o design precisa ter como ponto de partida a atual prática dos usuários - um fonte valiosa para o design de sistemas que deverão se adequar às novas práticas de trabalho.

- Experimentar o futuro. Uma maneira efetiva de permitir que os usuários empreguem seus conhecimento e habilidades é simular as futuras situações de uso, criando a ilusão de estar trabalhando com o sistema que ainda não está pronto. Desta maneira, a habilidade de mediar o trabalho do futuro aplicativo pode ser testada, e, de certa forma, as mudanças nas práticas de trabalho poderão ser previstas.

- Aprendizado e transcendência. $\mathrm{O}$ aprendizado é um importante ingrediente dos processos de design. Os diferentes grupos envolvidos aprendem sobre 0 trabalho e o background dos outros grupos, e o confronto com "estranhos no ninho" contribui para a compreensão de suas próprias práticas. Além disso, em situaçðes reais ou simuladas onde ocorrem colapsos - quando as pessoas envolvidas na ação param e refletem sobre o proprio trabalho -, o design assume caracterfsticas inovadoras: a abertura de possibilidades para novas maneiras de fazer as coisas, de transcender uma prática tradicional dos usuários e dos designers.

Aliado a estas questðes, é natural que surjam perguntasque precisam ser respondidas para permitir novas experiências na área e garantir a busca por respostas mais adequadas às exigências formuladas pelas transformações sociais e tecnológicas [73]:

- O que fazer quando surgem grandes conflitos e disputas de poder? Conhecer os grupos envolvidos e auxiliá-los a formular suas preocupações pode auxiliar os designers a compreender quais são os conflitos fundamentais existentes entre os grupos na organização. Geralmente os designers não podem resolver estes conflitos, mas algumas das técnicas apresentadas no capitulo 6 podem auxiliar os envolvidos a articularem suas proprias necessidades, e os designers podem ajudar a descobrir como agir em determinadas circunstâncias.

- Como fazer para que os administradores se envolvam no projeto? A maneira de agrupar as pessoas envolvidas deve ser escolhida cuidadosamente. Geralmente, as relações de poder entre as pessoas de um grupo de trabalho fazem com que as partes mais fracas não contribuam para o grupo.

- Esta não é forma mais lenta de executar um design? A experiência demonstra que as estimativas em um projeto dificilmente são realistas e que muitos projetos estouram seus prazos. Astécnicas apresentadas não resolvem este problema. Pode-se argumentar que, na verdade, a participação dos usuários faz aumentar a incerteza com relação aos prazos, já que os designers não 
conseguem antecipar quais os problemas que surgirão durante as atividades de design. Por um lado, as técnicas apresentadas podem ser vistas como iterativas, no sentido de que a introdução de novos aplicativos no ambiente de trabalho trara mudanças inesperadas na forma de trabalhar, o que leva a novas demandas dos próprios aplicativos. Por outro lado, estas técnicas, ao envolver os usuários nos projetos, devem aprimorar a qualidade dos produtos de-senvolvidos e auxiliar a antecipar alguns dos mais caros erros de design. Isto se deve ao fato de se enfatizar a interação usuário-designer desde o início, aliviando o peso dos problemas posteriores.

\section{Futuro do design cooperativo}

A melhor pista para tentar imaginar - utilizando-se aqui um termo da propria metodologia - a situação de uso futura do design cooperativo, está na definição de A. Henderson para as principais preocupaçôes da área de $\mathrm{HCI}$ nos próximos dez anos: cooperação, conflito, compreensão e compromisso [91]. Os estudos nestas sub-áreas, aliados a uma preocupação com as questões sociais e a um pluralismo na busca de novos avanços, torna o design cooperativo uma metodologia que permite uma visão otimista não só para os aplicativos computacionais, como também para o futuro das organizações e da sociedade como um todo ${ }^{1}$.

No caso específico de HCI, Winograd lembra que, "os departamentos de ciência da computação geralmente não são conhecidos por respeitarem muito o que é feito fora dos limites de sua disciplina. A formação na área de computação praticamente se concentrou apenas nos aspectos técnicos da disciplina, dando pouca atenção aos aspectos contextuais humanos que são cruciais para o design. Considerações sobre 'fatores humanos', 'impactos sociais', e 'metodologias para o design' aparecem apenas como acréscimos tangenciais ao estudo da 'verdadeira ciência da computação'. As pessoas e organizações são vistas muitas vezes como uma parte imprevisível e bagunçada do ambiente tecnologico". Ao mesmo tempo, Winograd acredita que a sociedade começou a pensar sobre o papel da tecnologia dentro de um contexto mais amplo, passando para uma posição mais cautelosa e direcionada para o design de novas tecnologias. "Temos que reconhecer que os benefícios potenciais da tecnologia surgirão apenas se dermos atenção suficiente ao contexto na qual a tecnologia for institúda. (...) Estamos começando a reconhecer que existe uma importante diferença entre 'eficiência', na acepção tradicionalmente usada na ciência da computação, e 'produtividade', no sentido prático de ob-ter maior valor do trabalho" [227].

O propósito da educação, segundo Winograd, é desenvolver a competência do estudante para realizar algum tipo de ação. "Muitas vezes, perdemos de vista esta questão em nossa ânsia de 'transmitir conhecimento' ou 'cobrir a matéria', mas no final esta é a justificativa para se ensinar qualquer coisa. No entanto, precisamos ser cuidadosos em não identificar competência com uma visão estreita de ação - com a habilidade de escrever código em uma particular linguagem de programação ou de criar algoritmos eficientes. Precisamos considerar domínios de ação e efeitos mais amplos nos quais nossos alunos irão trabalhar. (...) Eles precisam de competência em design - a atividade de agrupar novas tecnologias e novas práticas para que possam ser usadas. Para consolidar o potencial de nossos alunos no design de sistemas computacionais, precisamos desenvolver sua capacidade de relacionar o design de sistemas com as atividades $\mathrm{e}$ praticas humanas nas quais os sistemas estarão inclufdos" [227].
1. Particularmente. $\theta$ de se destacar os novos rumos do educaçao - principalmente na órea das Clênclas Exatasneste final de século. Três estudos mais gerais - 0 de $P$. Denning. "Educating a New Engineering (53), que trata do formaçáona área de computaça de manelra geral, $\theta$ o de L. Braun. "Help for All the Students" (25). que aborda sugestoespara os dirigentesescolares, e com relaçoo a $\mathrm{HCl} O$ deT. Winograd, "What Can We Teach About $\mathrm{HCl}^{-}$(227) sugerem mudanças radicaisno formaçao dos proflssionals da area. 
A partir deste contexto, dois novos papeis tomam forma como definidores do que está por vir: as figuras do designer e do usuário, e de como elas se situam no futuro do desenvolvimento de sistemas.

Papel do designer. Dentro da computação existem diversas carreiras e caminhos profissionais, o que cria uma demanda por diferentes tipos de competencia (veja [79]). No caso específico do design de interfaces e de sistemas, esta competência não é apenas uma questão de "prestar atenção no usuário". Como afirma Winograd, "para compreender o que realmente irá funcionar, precisamos ir além dos aspectos superficiais da "interface amigável' e da 'integração sem fronteiras" e procurar uma análise profunda do que as pessoas fazem em contextos sociais ou organizacionais, e como isto é influenciado pelo uso dos computadores". Esta visão mais ampla da influência dos computadores na maneira como as pessoas trabalham e vivem não está dentro dos limites da ciência da computação ou dos fatores humanos. Winograd afirma que "esta visão esbarra em várias das disciplinas que lidam sistematicamente com a atividade humana, incluindo a filosofia, a psicologia, a antropologia, e as ciências sociais" [227]. O designer será, no caso do design cooperativo, o facilitador do projeto, uma tarefa que envolve habilidades desenvolvidas nestas disciplinas.

Por essa razão, não é suficiente transformar o futuro designer em um sociólogo ou psicólogo amador. A enfase deve ser a de permitir o reconhecimento das possibilidades que são relevantes para a ação - no caso, as ações relevantes para o design de hardware, software, sistemas e interfaces computacionais. Segundo Winograd, podem ser identificadas algumas grandes áreas de conhecimento necessárias para a formação deste novo designer: as de interfaces, estrutura de trabalho, tecnologias de suporte, aprendizado, processos sociais, processos de design, e tecnologias de avaliação [227].

Papel do usuário. O usuário, em virtude da postura desse "novo" designer, deixa de ser uma coleção de dados antropométricos ou apenas um modelo mental. Seu envolvimento com a tecnologia é cada vez maior, assim como seu conhecimento sobre computação. Mais do que isso, o usuário está cotidianamente se debatendo com os problemas gerados pelo uso de computadores. Sua participação no design dos sistemas ou interfaces passa a ser crucial para que a evolução da tecnologia se processe de maneira mais democrática, mais eficiente e com maior qualidade.

Por outro lado, este usuário também precisará ser educado para poder cooperar. Parte desta tarefa será realizada dentro das próprias organizaçoes e empresas, mas outra parte deverá ser realizada pelos designers com os quais estarão em contato. A prática do design cooperativo traz em seu bojo, implicitamente, um novo conceito de usuário: o de um parceiro ativo na construção de interfaces e sistemas.

\section{Consideraçōes finais}

Este estudo fol iniciado a partir de uma preocupação com o design de interfaces. Descobrir o que há de errado com as interfaces supunha compreender como elas são construidas. O que, de infcio, tratava-se de uma busca por guidelines seguras para resolver os problemas detectados, transformou-se na identificação de uma série de questóes conceituais que precisavam ser equacionadas antes do aprofundamento em uma metodologia específica para construção de interfaces.

Definir "interface", "usuário", "interação" e "design" revelou-se uma questão intrincada: por detrás da aparente objetividade dos termos utilizados, a área "interface ho- 
mem-computador" mostrou-se, na primeira aproximação, um depositório de falsos pressupostos sobre os seres humanos e sobre o uso da tecnologia.

Livros como os de Heckel [90], Laurel [129], Norman [174], Tackara [218], e Winograd \& Flores [225], e artigos como os de Grudin [81], Anderson [91], Jacobson [99], Kapor [105], Kyng [124], Marcus \& van Dam [142], e Sculley [206], apontavam para a necessidade de "olhar com novos olhos" todos os problemas de se fazer o design de uma interface.

Da relaçãoentreorganizaçð̃es, conhecimentoe tecnologia, passando pela construção de software, até o próprio conceito de design, este estudo procurou identificar novos caminhos para transcender as práticas tradicionais, invariavelmente acusadas de serem as próprias geradoras dos problemas.

A primeira tarefa ficou evidente logo de início: Como compreender este "olhar" tradicional? Como se encaixavam estes falsos pressupostos na prática das equipes de desenvolvimento? Quais as implicações do uso destes pressupostos? O conceito de perspectiva foi fundamental, neste momento, para lançar uma nova luz sobre a concepção de interação homem-máquina e seu contexto.

Opróximo passo, guiado por esse conceito, foi o de conhecer a atual prática de design e as alternativas que estão sendo debatidas e implementadas. A partir deste ponto, o conjunto de conceitos e práticas denominado design cooperativo consolidou-se como um caminho que merecia ser explorado e aprofundado.

Os conceitos, apesar de dispersos e oriundos de várias áreas de conhecimento humano, apresentaram-se - ao serem reunidos neste estudo - como um corpo térico bem fundamentado e adequado para o tratamento dos problemas tanto de interfaces quanto de sistemas computacionais. Um exemplo da aplicação destes conceitos - o uso da teoria da atividade humana apresentado no Capítulo 5 - mostra a riqueza de temas para a pesquisa e indica possíveis resultados no design de interfaces.

No que se refere às práticas, os pesquisadores da área de computação podem se sentir um pouco frustados com a aparente falta de ferramentas e técnicas implementadas e testadas. Por tratar-se de uma jovem metodologia, talvez este aspecto justamente revele sua força. Uma nova maneira de olhar o mundo exige novos artefatos, novas ferramentas e novas técnicas.

Por esta razão, a busca por guidelines mostrou-se infrutffera: a própria natureza da metodologia impede este tipo de resultado. A dinâmica do uso de computadores e a diversidade de situaçóes onde ocorre esse uso, impedem o surgimento deste tipo de restriç̋̃es.

Mais importante do que guidelines, projetos recentes indicam a necessidade de se criar condiçðes para apoiar o design cooperativo. Suporte para a comunicação entre os participantes, para a coordenação dos trabalhos, e para o aprendizado mútuo destacamse como desafios para os próximos anos. As tecnologias de hipermídia, trabalho cooperativo auxiliado por computador (CSCW, computer-supported cooperative work), e técnicas de inteligência artificial tais como raciocínio baseado em casos (case based reasoning), surgem como candidatos naturais para a pesquisa e o desenvolvimento.

Mais do que uma revisão de conceitos e práticas, este estudo pretende ter o mérito de chamar a atenção para algumas das implicaçōes das pesquisas em design cooperativo. Implicaçães que podem, a seu tempo, modificar a posição dos computadores na sociedade e de como estes artefatos podem ser usados pelos seres humanos.

No final das contas, tudo leva a crer que cooperação faz sentido. 
[1] E. Auramäki, E. Lehtinen \& K. Lyytinen, "A Speech-Act-Based Office Modelling Approach", ACM Transactions on Office Information Systems, 6(2), 1988, 126-152.

[2] E. Auramaki, R. Hirschheim \& K. Lyytinen, "Modelling Offices Through Discourse Analysis: The sAMPO Approach", The Computer Joumal, 35(4), 1992, 342-352.

[3] E. Auramaki, R.Hirschheim \& K. Lyytinen. "Modelling Offices through Discourse Analysis: A Comparison and Evaluation of SAMPO with OSSAD and ICN", The Computer Joumal, 35(5), 1992, 492-500.

B

[4] R. M. Baecker, "A Vision of Education in User-Centered System and Interface Design", ACM SIGCHI Bulletin, 20(3), 1989, 10-13.

[5] R. M. Baecker \& W. A. S. Buxton, Readings in Human Computer Interaction, Morgan Kaufmann, Los Altos, CA, 1987.

[6] H. Bahrami, "The Emerging Flexible Organization: Perspectives from Silicon Valley", California Management Review, 34(4), 1992, 33-52.

[7] L. J. Bannon, "From Human Factors to Human Actors: The Role of Psychology and Human-Computer Interaction Studies in System Design", in: J. Greenbaum \& M. Kyng (eds), Design at Work: Cooperative Design of Computer Systems, Lawrence Erlbaum, Hillsdale, NJ, 1991, 25-44.

[8] L. J. Bannon, "Issues in Design: Some Notes", in: D. A. Norman \& S. W. Drapper, User Centered Systems Design: New Perceptions in Human Computer Interaction, Lawrence Erlbaum, Hillsdale, NJ, 1986, 25-29.

[9] L. J.Bannon, “A Pilgrims Progress: From Cognitive Science to Cooperative Design", AI \& Society, 4, 1990, 259-275.

[10] M. Benedikt, "Introduction", in: M.Benedikt (ed.), Cyberspace: First Steps, MIT Press, Cambridge, MA, 1991, 1-25.

[11] M. Benedikt "Virtual Worlds: No Interface To Design", in: M. Benedikt (ed.), Cyberspace: First Steps, MIT Press, Cambridge, MA, 1991, 363-382.

[12] M. Benedikt (ed.), Cyberspace: First Steps, MIT Press, Cambridge, MA, 1991.

[13] P. Berger \& T. Luckmann, The Social Construction of Reality: A Treatise in the Sociology of Knowledge, Doubleday, NY, 1967.
[14] G. Bishop etal., "Research Directions in Virtual Environments", Computer Graphics, 26(3), agosto 92, 153-177.

[15] G. P. Bjerknes, "Some PD Advice", Communications of the $A C M, 36(6), 1993$, 39.

[16] G. P. Bjerknes, P. Ehn \& M. Kyng (eds.), Computer and Democracy: A Scandinavian Challenge, Aldershot, Avebury, UK, 1987.

[17] N. Bjørn-Andersen, M. Earl, O. Holst \& E. Mumford (eds.), Information Society, for Richer, for Poorer, North-Holland, Amsterdam, 1982.

[18] D. C. Blair, "Information Retrieval and the Philosophy of Language", The Computer Joumal, 35(3), 1992, 200-207.

[19] D. Bloor, Wittgestein: A Social Theory of Knowledge, Columbia University Press, NY, 1983.

[20] D. G. Bobrow, "Dimensions of Interaction", Al Magazine, 12(3), outono 1991, 64-80.

[21] R.Boland, "Phenomenology: A Prefered Approach to Research in Information Systems", in [161], 193-202.

[22] N. S. Borenstein, Programming As If People Mattered: Friendly Programs, Software Engineering, and Other Noble Delusions, Princeton University Press, Princeton, NJ, 1991.

[23] C. A. Bowers, "Teaching a NineteenthCentury Mode of Thinking Through a Twentietb-Century Machine", Educational Theory, 38(1), inverno 1988, 41-46.

[24] S. Brand, The Media Lab: Inventing the Future at MIT, Viking, NY, 1987.

[25] L. Braun, "Help for All the Students", Communications of the $A C M, 36(5), 1993$, 66-69.

[26] S.Brennan, "Conversation as Direct Manipulation: An Iconoclastic View", in: B. Laurel (ed.), The Ant of Human Computer Interface Design, Addison-Wesley, Reading, MA, 1990, 393-404.

[27] U. Briefs, C. Ciborra \& L. Schneider (eds.), Systems Design For, With, and By the Users, North-Holland, Amsterdam, 1983.

[28] J. S. Brown, "From Cognitive to Social Ergonomics and Beyond", in: D. A. Norman \& S. W. Drapper, User Centered Systems Design: New Perceptions in Human Computer Interaction, Lawrence Erlbaum, Hillsdale, NJ, 1986, 457-486. 
[29] K. A. Bruffee, "Social Construction, Language, and the Authority of Knowledge: A Bibliographical Essay", College English, 48(8), 1986, 773-790.

[30] R. Budde, K. Kuhlenkamp, L. Mathiassen \& H. Zullinghoven (eds.), Approaches to Prototyping, Springer-Verlag. Berlin, 1984.

[31] R. Budde, C. Floyd, R. Keil-Slavik \& H. Zullinghoven (eds.), Software Development and Reality Construction, SpringerVerlag, Berlin, 1992.

[32] S.Bødker, “A Human Activity Approach to User Interfaces", Human-Computer Interaction, 4(2), 1989, 171-195.

[33] S. Bødker, Through the Interface: A Human Activity Approach to User Interface Design, Lawrence Erlbaum, Hillsdale, NJ, 1991.

[34] S. Bødker, P. Ehn, J. L. Knudsen, M. Kyng \& K. H. Madsen, "Computer Support for Cooperative Design", in: D. Tatar (ed.), Proceedings of Computer-Supponed Cooperative Work Conference' 88 , ACM Press, 1992, 377-394.

[35] S. Bødker, J. Greenbaum \& M. Kyng, "Setting the Stage for Design as Action", in: J. Greenbaum \& M. Kyng (eds), Designat Wonk: Cooperative Design of Computer Systems, Lawrence Erlbaum, Hillsdale, NJ, 1991, 139-154.

[36] S. Bødker \& K. Grønbæk," Cooperative Prototyping: Users and Designers in $\mathrm{Mu}$ tual Activity", International Journal of Man-Machine Studies, 34(6), 1991, 453 478.

[37] S. Bødker \& K. Grønbzk, "Design in Action: From Prototyping by Demonstration to Cooperative Prototyping", in: J. Greenbaum \& M. Kyng (eds), Design at Work: Cooperative Design of Computer Systems, Lawrence Erlbaum, Hillsdale, NJ, 1991, 197-218.

C

[38] P. A. Carlson, "Virtual Text and New Habits of Mind", in: H. Maurer (ed.), New Results and New Trends in Computer Science, Lectures Notes in Computer Science 555, Springer-Verlag, Berlin, 1991, 25 53.

[39] J. M. Carrol \& M. B. Rosson, “'Getting Around the Task-Artifact Cycle: How to Make Claims and Design by Scenario". ACM Transactions on Information Systems, 10(2), 1992, 181-212.
[40] J. Carter, "Managing Knowledge: The New Systems Agenda", IEEE Expert, 7(6), junho 1992, 3-4.

[41] P. Checkland, Systems Thinking, Sys tems Practice, Wiley, Chichester, England, 1981.

[42] W.J.Clancey, "Situated Action: A Neuropsychological Interpretation Response to Vera and Simon", Cognitive Science 17(1), 1993, 87-116.

[43] H. Clausen, "Concepts and Experiences with Participative Design Approaches", in: N.Szuperski \& E. Grochla, Design and Implementation of Computer-Based Information Systems, Sithoff \& Noordhoff, Alphen aan den Rijn, Netherlands, 1979 , 231-242.

[44] A. Clement \& P. van den Besselaar, “A Retrospective Look at PD Projects", Communications of the ACM, 36(6), 1993, 29 37.

[45] A. M.Cohill, "Information Architecture and the Design Process", in: J. Karat (ed.), Taking Software Design Seriously: Practical Techniques for Human-Computer Interaction Design, Academic Press, NY, 1991, 95-113.

[46] M. Cooley, "From Brunelleschi to CADCAM", in: J. Tackara (ed.), Design After Modernism, Thames \& Hudson, London, 1988, 197-207.

[47] J. Coulter, The Social Construction of Mind: Studies in Ethnomethodology and Linguistic Philosophy, Rowman, Totona, NJ, 1979.

[48] B. Curtis, "Insights from Empirical Studies of the Software Design Process", $F_{\boldsymbol{u}}$ ture Generation Computer Systems, 7, 1991/92, 139-149.

D

[49] G. B. Davies, "Strategies for Information Requirements Determination", IBM Systems Journal, 21(1), 1982, 4-30.

[50] T. Dayton, "Cultivated Eclecticism as the Normative Approach to Design", in: J. Karat (ed.), Taking Software Design Seriously: Practical Techniques for HumanComputer Interaction Design, Academic Press, NY, 1991, 21-44.

[51] A. De Maio, "Socio-Technical Methods for Information Systems Design", in: H. C. Lucas, F. Land, T. J. Lincoln \& K. Supper (eds.), The Information Systems Environment, North- Holland, 1980, 105-122.

[52] P. J. Denning, "Work is a Closed-Loop Process",American Scientist, 80(4), julho/ agosto 1992, 314-317. 
[53] P. J. Denning, "Educating a New Engineer", Communications of the ACM, 35(12), dezembro 1992, 84-97.

[54] B. Dervin, "User as Research Inventions: How Research Categories Perpetuate Inequities", Journal of Communication, 39(3), 1989, 216-232.

[55] B. Dervin \& K. D. Clark, "Communication as Cultural Identity: The Invention Mandate", Media Development, 36(2), 1989, 5-8.

[56] P. Docherty, K. Fuchs-Kittowsky, P. Kolm \& L. Mathiassen (eds.), System Design for Human Development and Productivity: Participation and Beyond, North-Holland, Amsterdam, 1987.

[57] P. F. Drucker, "The New Society of Organizations", Harvard Business Review, setembro/outubro 1992, 95-104.

E

[58] P. Ehn, Work-Oriented Design of Computer Artifacts, Lawrence Erlbaum, Hillsdale, NJ, 1989.

[59] P. Ehn \& M. Kyng, "Cardboard Computers: Mocking-It-Up or Hands-On the Future", in: J. Greenbaum \& M. Kyng (eds), Design at Work: Cooperative Design of Computer Systems, Lawrence Erlbaum, Hillsdale, NJ, 1991, 169-195.

[60] T.D. Erickson, "Creativity and Design", in: B. Laurel (ed.), The An of Human Computer Interface Design, AddisonWesley, Reading, MA, 1990, 1-4.

F

[61] M.Falanga, "StartMaking Sense:Designing with User Participation", Design Methods and Theories, 21(4), 1987, 732-738.

[62] F. Flores, M. Graves, B. Hartfield \& T. Winograd, "Computer Systems and the Design of Organizational Interaction", ACM Transactions on Office Information Systems, 6(2), 1988, 153-172.

[63] C. Floyd, 'Outline of a Paradigm Change in Software Engineering", ACM SIGSOFT Software Engineering Notes, 13(2), 1988, 25-38.

[64] C. Floyd, F.-M. Reisin \& G. Schmidt, "sTEPs to Software Development with Users", in: C. Ghezzi \& J. A. McDermid (eds.), ESEC'89, Lectures Notes in Computer Science 387, Springer-Verlag, Berlin, 1989, 49-64

[65] C. Floyd, W.-M. Mehl, F.-M. Reisin, G. Schmidt \& G. Wolf, "Out of Scandinavia: Altemative Approaches to Software De- sign and System Development", HumanComputer Interaction, 4(4), 1989, 253. 350.

[66] W. Foley et al., Fundamentals of Interactive Computer Graphics, 2nd edition, Addison-Wesley, Reading, MA, 1990.

[67] A. L. Friedman, Computer Systems Development: History, Organization and Implementation, John Wiley, Chichester, UK, 1989.

G

[68] J. J.Gabarro, "The Development of Working Relationships", in: J. Galegher, R.E. Kraut \& C. Egido (eds.), IntellectualTeamwork: Social and Technological Foundations of Cooperative Work, Lawrence Erlbaum, Hillsdale, NJ, 1990, 79-110.

[69] J. Galegher, R. E. Kraut \& C. Egido (eds.), Intellectual Teamwork: Social and Technological Foundations of Cooperative Work, Lawrence Erlbaum, Hillsdale, NJ, 1990.

[70] C. Geertz, Local Knowledge: Funther Essays in Interpretive Anthropology, Basic Books, NY, 1983.

[71] C.Geertz, Works and Lives: The Anthropologist as Author, Polity Press, Cambridge, UK, 1988.

[72] J. Greenbaum \& M. Kyng, "Introduction: Situated Design", in: J. Greenbaum \&M. Kyng (eds), Design at Work: Cooperative Design of Computer Systems, Lawrence Erlbaum, Hillsdale, NJ, 1991, 1- 24.

[73] J. Greenbaum \& M. Kyng (eds), Design at Work: Cooperative Design of Computer Systems, Lawrence Erlbaum. Hillsdale, NJ, 1991.

[74] S. Greenberg, "An Annotated Bibliography of Computer Supported Cooperative Work", ACM SIGCHI Bulletin, 23(3), 1991, 29-62.

[75] J.Greenbaum, A. Kjœr \& K. H. Madsen, "Analysing Diversity in Organization: The Dependencies Between Work Activities, Technical Artifacts, Space, and Work Organization". Draft Paper, fevereiro 1993.

[76] J. Grudin, "The Case Against User Interface Consistency", Communication of the ACM, 32(10), 1989, 1164-1173.

[77] J. Grudin, "The Computers Reaches Out: The Historical Continuity of Interface Design", in: J. C. Carrasco \& J. Whiteside, Empowering People, Proceedings of the ACM SIGCHI Conference, ACM Press, 1990, 261-268. 
[78] J. Grudin, "Groupware and Cooperative Work: Problems and Prospects", in: B. Laurel (ed.), The An of Human Computer Interface Design, Addison-Wesley, Reading, MA, 1990, 171-185.

[79] J. Grudin, "Interface: An Evolving Concept", Communications of the ACM,36(4), $1993,110-119$.

[80] J. Grudin, "Obstacles to User Involvement in Software Product Development with Implications for Computer-Supported Cooperative Work", International Journal of Man-Machine Studies, 34(8), 1991, 435-452.

[81] J. Grudin, "The Development of Interactive Systems: Bridging the Gaps Between Developers and Users", IEEE Computer, 24(4), abril 1991, 59-69.

[82] J. Grudin, "Consistency, Standards, and Formal Approaches to Interface Development and Evaluation: A Note on Wiccha, Bennett, Boies, Gould and Greene", $A C M$ Transactions on Information Systems, 10(1), 1992, 103-111.

[83] K. Gronbæk, Prototyping and Active User Involvement in System Development: Towards a Cooperative Prototyping Approach. PhD Thesis, Computer Science Department, Århus University, setembro 1991.

[84] K. Grønbæk, M. Kyng \& P. Mogensen, "CSCW Challenges: Cooperative Design in Engineering Projects", Communications of the ACM, 36(6), 1993, 67-77.

H

[85] J. Habermas, Conhecimento e Interesse, Editora Zahar, 1982.

[86] J. Habermas, The Theory of Communicative Action, Beacon Press, Boston, 1984.

[87] D. D. Hade, "Literacy in an Information Society", Educational Technology, agosto 1982, 7-12.

[88] B. Hartfield, T. Winograd \& J. Bennett, "Learning HCI Design: Mentoring Project Groups in a Course on Human-Computer Interaction",ACM SIGCSE Bulletin, 24(1), março 1992, 246-251.

[89] J. Hawkins, "Technology and the Organization of Schooling", Communications of the ACM, 36(5), 1993, 30-35.

[90] P. Heckel, The Elements of Friendly Software Design, 2nd edition, Sybex, Alameda, CA, 1991.

[91] A. Henderson, "Perspectives on HumanComputer Interaction", IEEE Software, 9(4), julbo 1992, 70-71.
[92] R. Hirschbeim, "Information Systems Epistemology: An Historical Perspective", in: E. Mumford, R. Hirschheim, G. Fitzgerald \& A. T. Wood-Harper (eds.), Research Methods in Information Systems, North-Holland, Amsterdam, 1985, 13-38.

[93] R. Hirschheim, "Participative Systems Design: User Experiences, Evaluation and Conclusions", The Australian Computer Journal, 18(4), 1986, 166-179.

[94] R. Hirschbeim \& H. K. Klein, "Four Paradigms of Information Systems Development", Communications of the ACM, 32(10), 1989, 1199-1216.

[95] R. Hirschbeim, "The Effect of A Priori Views on the Social Implications of Computing: The Case of Office Automation", ACM Computer Suney, 18(2), 1986, 165 195.

[96] E. J. Holubec, "How Do You Get There From Here? Getting Started With Cooperative Learning", Contemporary Education, 63(3), 1992, 181-184

[97] R. Höyer, "User Participation: Why is Development so Slow? The Dynamics of the End User Control", in: H.C. Lucas, F. Land, T. J. Lincoln \& K. Supper (eds.), The Information Systems Environment, North-Holland, 1980, 129-138.

\section{I/J}

[98] K. Issrof, "Methodology for Research in Computer Supported Cooperative Learning", in: AI Tools and the Classroom: Theory into Practice, Proceedings of the Seventh International PEG Conference, 1993, 421-433.

[99] B. Jacobson, "The Ultimate User Interface", Byte, abril 1992, 175-182.

[100] D. W. Johnson \& R. T. Johnson, "Implementing Cooperative Learning", Contemporary Education, 63(3), 1992, 173-180.

[101] J. Johnson, T. L. Roberts, W. Verplank, D. C. Smith, C. H. Irby, M. Beard \& K. Mackey, "The Xerox Star: A Retrospective", IEEE Computer, 22(9), setembro 1989, 11-29.

[102] J. C. Jones, Design Methods: Seeds of Human Futures, Wiley \& Sons, London, 1970.

[103] J. C. Jones, “Softecnica”, in: J. Tackara (ed.), Design After Modernism, Thames \& Hudson, London, 1988, 216-226. 


\section{K}

[104] J. Kammersgaard, "Four Perspectives in Human-Computer Interaction", International Joumal of Man-Machine Studies, 28(4), 1988, 343-362.

[105] M. Kapor, "A Software Design Manifesto", Dr. Dobbs Joumal, janeiro 1991, 62-67.

[106] J. Karat (ed.), Taking Software Design Seriously: Practical Techniques for $\mathrm{Hu}$ man-Computer Interaction Design, Academic Press, NY, 1991.

[107] A. Kay, "User Interface: A Personal View", in: B. Laurel (ed.), The Art of Human Computer Interface Design, AddisonWesley, Reading, MA, 1990, 191-207.

[108] A. Kay, "Computers and Education", Scientific American, 264(3), setembro 1991, 101-107.

[109] F. Kensing \& K. H. Madsen, "Genera ting Visions: Future Workshops and Metaphorical Design", in: J. Greenbaum \& M. Kyng (eds), Design at Work: Cooperative Design of Computer Systems, Lawrence Erlbaum, Hillsdale, NJ, 1991, 155-168.

[110] F. Kensing \& A. Munk-Madsen, "PD: Structure in the Toolbox", Communications of the ACM, 36(6), 1993, 78-85

[111] P. Kerola, "Knowledge About Human Information Processing and Learning Styles in the Education of Systems Architects", Education \& Computing, 6, 1990, 3-14.

[112] S. Kerr, "Wayfinding in an Electronic Database: The Relative Importance of $\mathrm{Na}-$ vigational Cues vs. Mental Models", Information Processing \& Management, 26(4), 1990, 511-523.

[113] H. K. Klein \& K. Lyytinen, "The Poverty of Scientism in Information Systems Development", in: E. Mumford, R. Hirschheim, G. Fitzgerald \& A. T. Wood-Harper (eds.), Research Methods in Information Systems, North-Holland, Amsterdam, 1985, 131-161.

[114] H. K. Klein \& R. A. Hirschheim, "A Comparative Framework of Data Modelling Paradigms and Approaches", The Computer Joumal, 30(1), 1987, 8-15.

[115] M. Klein, "Supporting Conflict Resolution in Cooperative Design Systems", IEEE Transactions on Systems, Man, and Cybernetics, 21(6), 1991, 1379-1390.

[116] R. Kling, "Social Analysis of Computing: Theoretical Perspectives in Recent Empirical Research", ACM Computing Surveys, 12(1), março 1980, 61-110.
[117] R. Kling, "The Social Web of Computing: Computer Technology as Social Organization", Advances in Computing 21, Academic Press, NY, 1982, 2-90.

[118] R. Kling, "Cooperation, Coordination and Control in Computer-Supported Work", Communication of the ACM, 34(12), 1991, 83-88.

[119] R. Kling \& W. Scacchi, "Computer as Social Action: The Social Dynamics of Computing in Complex Organizations", Advances in Computer 19, Academic Press, NY, 1980, 247-327.

[120] K. L. Kraemer \& J. L. King, "Computer-Based Systems for Cooperative Work and Group Decision Making", $A C M$ Computing Surveys, 20(2), 1988, $115-146$.

[121] R. M. Krauss \& S. R. Fussell, "Mutual Knowledge and Communicative Effectiveness", in: J. Galegher, R. E. Kraut \& C. Egido (eds.), Intellectual Teamwork: Social and Technological Foundations of Cooperative Work, Lawrence Erlbaum, Hillsdale, NJ, 1990, 111-145.

[122] T. S. Kuhn, A Estrutura das Revoluções Cientfficas, Editora Perspectiva, 2 edição, SP, 1978.

[123] M. Kyng (em colaboração com J. Greenbaum), "Cooperative Design: Bringing together the Practices of Users and Designers", in: H.-E. Nissen, H. K. Klein \& R. Hirschheim (eds.), Information Systems Research: Contemporary Approaches and Emergent Traditions, North-Holland, Amsterdam, 1991, 405-415.

[124] M. Kyng, “Designing for Cooperation: Cooperating in Design", Communications of the ACM, 34(12), 1991, 64-73.

[125] M. Kyng, "Scenario? Guilty!", ACM SIGCHI Bulletin, 24(4), 1992, 8-9.

\section{L}

[126] G. Lakoff \& M. Johnson, Metaphors We Live By, University of Chicago Press, Chicago, 1980.

[127] F. Land \& R. Hirschheim, "Participative Systems Design: Rationale, Tools and Techniques", Joumal of Applied System Analysis, 10(6), 1983, 91-106.

[128] F. Land, "Is an Information Theory Enough?', The Computer Joumal, 28(3), 1985, 211-215.

[129] B. Laurel (ed.), The An of Human Computer Interface Design, Addison-Wesley, Reading, MA, 1990. Addison-Wesley, Reading, MA, 1991. 
[131] E. Lehtinen \& K. Lyytinen, "Action Based Model of Information System", Information Systems, 11(4), 1986, 299-317.

[132] P. Lévy,As Tecnologias da Inteligência: O Futuro do Pensamento na Era da Informática, Editora 34, RJ, 1993.

[133] K. Lyytinen \& H. K Klein, "The Critical Theory of Jürgen Habermas as a Basis for a Theory of Information Systems", in: E.Mumford, R. Hirschbeim, G. Fitzgerald \& A. T. Wood-Harper (eds.), Research Methods in Information Systems, NorthHolland, Amsterdam, 1985, 219-237.

[134] K. Lyytinen, “Implications of Theories of Language for Information Systems", MIS Quaterty, março 1985, 61-74.

[135] K. Lyytinen, "A Taxonomic Perspective of Information Systems Development: Theoretical Constructs and Recommendations", in: R. Boland \& R. Hirschheim (eds.), Critical Issues in Information Systems Research, Wiley \& Sons, Chichester, 1987, 3-41.

[136] K. Lyytinen, "Different Perspectives on Information Systems: Problems and Solutions", ACM Computing Surveys, 19(1), 1987, 5-46.

[137] K. Lyytinen, "Two Views of Information Modeling", Information \& Management, 12(1), 1987, 9-19.

M

[138] K.H.Madsen \& P.H. Aiken, "Experiences Using Cooperactive Interactive Storyboard Prototyping", Communications of the ACM, 36(6), 1993, 57-64.

[139] T. W. Malone \& J. F. Rockart, "Computers, Networks, and the Corporation", Scientific American, 264(3), setembro 1991, 92-99.

[140] G. Marchionini \& J. Sibert, “An Agenda for Human-Computer Interaction: Science and Engineering Serving Human Needs", ACM SIGCHI Bulletin, 23(4), 1991, 17 32.

[141] A. Marcus, "Human Communications Issues in Advanced UIs", Communications of the ACM, 36(4), 1993, 100-109.

[142] A. Marcus \& A. van Dam, "User-Interface Developments for the Nineties", IEEE Computer, 24(9), setembro 1991, 49-57.

[143] M. L. Markus \& N. Bjøm-Andersen, "Power Over Users: Its Exercise by System Professionals", Communications of the ACM, 30(6), 1987, 498-504.
[144] R. O. Mason \& I.I. Mitroff, "A Program for Research on Management Information Systems", Management Science, 19(5), 1973, 475-487.

[145] H. R. Maturana, "The Biological Foundations of Self-Consciouness and the Physical Domain of Existence", in: E. R. Caianello(ed.), Physics of Cognitive Processes, World Scientific, Singapore, 1987, 324 379.

[146] H. R. Maturana \& F. J. Varela, The Tree of Knowledge: The Biological Roots of Human Understanding, Shambala, Boston, 1987.

[147] M.McLuhan, A Galaxia de Gutemberg, Nacional, SP, 1977.

[148] M. McLuhan, Os Meios de Comunicação como Extensão do Homem, Cultrix, SP, 1979.

[149] M. McLuhan \& E. McLuhan, The Laws of Media, University of Toronto Press, Toronto, 1988.

[150] M. A. Meyer, "How to Apply the Anthropological Technique of Participant Observation to Knowledge Acquisition for Expert Systems", IEEE Transactions on Systems, Man, and Cybemetics, 22(5), 1992, 983-991.

[151] S. E. Miller, "From System Design to Democracy", Communications of the ACM, 36(6), 1993, 38.

[152] T. Mitchell, "The Product as Illusion", in: J. Tackara (ed.), Design After Modernism, Thames \& Hudson, London, 1988, 208-215.

[153] N. Miyake, "Constructive Interaction and the Iterative Process of Understanding", Cognitive Science, 10(2), 1986, 151 177.

[154] J. Morrison \& O. R. Liu Sheng, "Communication Technologies and Collaboration Systems: Common Domains, Problems and Solutions", Information \& Management, 23(2), 1992, 93-112.

[155] P. Morrison \& P. Morrison, The Ring of Truth: An Inquin Into How We Know What We Know, Vintage Books, 1989.

[156] M. J. Muller, J. G. Smith, J. Z. Shoher \& H. Goldberg, Privacy, "Anonymity and Interpersonal Competition Issues IdentifiedDuring Participatory Design of Project Management Groupware", ACM SIGCHI Bulletin, 23(1), 1991, 82-87.

[157] M. J. Muller, D. M. Wildman \& E. A. White, "Taxonomy of PD Practices: A Brief Practitioner's Guide", Communica. tions of the ACM, 36(6), 1993, 26-27. 
[158] E. Mumford, "Consensus System Design: An Evaluation of this Approach", in: N. Szuperski \& E. Grochla (eds.), Design and Implementation of Computer-Based Information Systems, Sithoff \& Noordhoff, Alphen aan den Rijn, Netherlands, 1979. 221-230.

[159] E. Mumford, "Participative Systems Design: Structure and Method", Systems, Objectives, Solutions, 1(1), 1981, 5-19.

[160] E. Mumford, N. Bancroft \& B. Sontag, "Participative Design: Sucesses and Problems", Systems, Objectives, Solutions, 3(2), 1983, 133-141.

[161] E. Mumford, R. Hirschheim, G. Fitzgerald \& A. T. Wood-Harper (eds.), Research Methods in Information Systems, North-Holland, Amsterdam, 1985.

[162] B. A. Myers, "Demonstrational Interfaces: A Step Beyond Direct Manipulation", IEEE Computer, agosto 1992, 6173.

\section{$\mathbf{N}$}

[163] P.Naur, "Intuition in Software Development", in: H. Ehrig, C. Floyd, M. Nivat \& J. Thatcher (eds.), Formal Methods and Software Development, Lecture Notes in Computer Science 186, Springer-Verlag, Berlin, 1985, 60-79.

[164] G. Nelson, Problems of Design, Whitney Publications, 2nd edition, NY, 1965.

[165] T.H.Nelson, ComputerLib/Dream Machines, revised edition, Microsoft Press, Redmond, WA, 1987.

[166] T.H. Nelson, "The Right Way to Think About Software Design", in: B. Laurel (ed.), The Art of Human Computer Interface Design, Addison-Wesley, Reading, MA, 1990, 235-243.

[167] P. G. Neuman, "Tllustrative Risks to the Public in the Use of Computer Systems and Related Technology", ACM SIGSOFT Software Engineering Notes, 17(1), janeiro 1988, 23-32.

[168] W. M. Newman \& R. F. Sproull, Principles of Interactive Computer Graphics, McGraw-Hill, London, 1979.

[169] D. A. Norman, "Collaborative Computing: Collaboration First, Computing Second", Communication of the $A C M, 34(12)$, 1991, 88-90.

[170] D. A. Norman, "Human Error: Once More, With Feeling",ACMSIGSOFT Software Engineering Notes, 17(1), 1992, 22.

[171] D. A. Norman (ed.), "Special Issue on Situated Action", Cognitive Science, 17(1), 1993, 1-147.
[172]D. A. Norman, "Twelve Issues for Cognitive Science", Cognitive Science, 4(1), 1980, 1-32.

[173] D. A. Norman, "Stages and Levels in Human Machine Interaction", International Journal of Man-Machine Studies, 21(6), 1984, 365-375.

[174] D. A. Norman, The Design of Everyday Things, Basic Books, NY,1988.

[175] D. A. Norman \& S. W. Drapper, User Centered Systems Design: New Perceptions in Human Computer Interaction, Lawrence Erlbaum, Hillsdale, NJ, 1986.

[176] K. Nygaard, 'Program Development as a Social Activity", in: H. J. Kugler (ed), Information Processing, Elsevier, Amsterdam, 1986, 189-198.

O

[177] H. Oberquelle, I. Kupka \& S. Maass, “A View of Human-Machine Communication and Co-operation", International Journal of Man-Machine Studies, 19(3), 1983, 309-333.

[178] J. Olaisen, "Information as a Strategic Resource: AQuestion of Communication", in: R. Andersen, J. A. Bubenko Jr. \& A. Sølvberg (eds.), Advanced Information Systems Engineering, Lecture Notes in Computer Science 498, Springer-Verlag, Berlin, 1991, 141-167.

[179] T. W. Olle, H. Sol \& C. Tully (eds.), Information Systems Design Methodologies: A Feature Analysis, North-Hollan, Amsterdam, 1983.

[180] M. H. Olson \& B. Ives, "User Involvement in System Design: An Empirical Test of Alternative Approaches", Information \& Management, 4(3), 1981, 183-195.

[181] T. Oren, "Designing a New Medium", in: B. Laurel (ed.), The Ant of Human Computer Interface Design, AddisonWesley, Reading, MA, 1990, 467-479.

P

[182] R.Pearlman, "Designing the New American Schools", Communications of the ACM, 36(5), 1993, 46-48.

[183] M.Polanyi, Personal Knowledge, Routledge \& Kegan Paul, London, 1958.

[184] M. Polanyi, The Tacit Dimension, Doubleday, Garden City, NY, 1967.

[185] P. R. Portes, "The Role of Language in the Development of Intelligence: Vygotsky Revisited", Joumal of Research and Development in Education, 18(4), 1985, 1- 
[186] M. Poster, The Mode of Information: Poststructuralism and Social Context, University of Chicago Press/Polity Press, Chicago/Cambridge, UK, 1990.

[187] J. Preece (ed.), Human Computer Interaction, Open University/Prentice-Hall, London, 1990.

[188] J. Preece, "Human-Computer Interaction in the Informatics Curriculum", Education \& Computing, 9, 1993, 295-301.

[189] J. Preece \& L. Keller, "Key Issues in HCI Curriculum Design", $A C M$ SIGCHI Bulletin, 22(1), 1990, 67-69.

\section{Q/R}

[190] J.S. Quaterman, The Matrix: Computer Networks and Conferencing Systems Worldwide, Digital Press, NY, 1990.

[191] M. Rettig, "Cooperative Software", Communications of the ACM, 36(4), 1993, 23-28.

[192] H. Rheingold, “An Interview with Don Norman", in: B. Laurel (ed.), The Art of Human Computer Interface Design, Addison-Wesley, Reading, MA, 1990, 5-10.

[193] R. Rorty, Philosophy and the Mirror of Nature, Princeton University Press, Princeton, NJ, 1979.

[194] D. T. Ross \& K. E.Schoman Jr., "Structured Analysis and Requirements Definition", IEEE Transactions on Software Engineering, 3(1), 1977, 6-15.

[195] D. T. Ross, "Applications and Extensions of SADT", IEEE Computer, 3(4), 1985, 25-34.

\section{5}

[196] A.Sandberg, "Socio-Technical Design, Trade Union Strategies and Action Research", in: E. Mumford, R. Hirschheim, G. Fitzgerald \& A.T. Wood-Harper (eds.), Research Methods in Information Systems, North-Holland, Amsterdam, 1985, 79-92.

[197] R. Savolainen, "The Sense-Making Theory: Reviewing the Interests of a UserCentered Approach to Information Seeking and Use", Information Processing \& Management, 29(1), 1993, 13-28.

[198] W. Scacchi, "Managing Software Engineering Projects: A Social Analysis", IEEETransactions on Software Engineering, 10(1), 1984, 49-59.

[199] M. Scardamalia \& C. Bereiter, "Technologies for Knowledge-Building Discourse", Communications of the $A C M$, 36(5), 1993, 37-41.
[200] R. C. Schank, "Learning via Multimedia Computers", Communications of the ACM, 36(5), 1993, 54-56.

[201] R. C. Schank, "Where's the AI?", AI Magazine, 12(4), winter 1991, 38-49.

[202] B. Schneiderman, Designing the User Interface: Strategiesfor Effective HumanComputer Interaction Addison-Wesley, Reading, MA, 2nd edition, 1992.

[203] B. Schneiderman, "Engagement and Construction: Educational Strategies for the Post-TV Era", in: I. Tomek (ed.), Computer Assisted Learning, Lecture Notes in Computer Science 602, Springer-Verlag, Berlin, 1992, 39-45.

[204] D. Schuller \& A. Namioka (eds.), Participatory Design, Lawrence Erlbaum, Hillsdale, NJ, 1993.

[205] J. Sculley, Odisséia: da Pepsi da Apple: Uma Viagem através da Aventura, das Idéiase do Futuro, BestEditora, São Paulo, 1987.

[206] J. Sculley, "The Relationship Between Business and Higher Education: A Perspective on the 21 st Century", Communications of the ACM, 32(9), 1989, 1056-1061.

[208] R. E. Slavin, Cooperative Learning: Theory, Reserach, and Practice, PrenticeHall, Engelwood Cliffs, NJ, 1991.

[209] E. Soloway, "Reading and Writing in the 21 st Century", Communications of the $A C M, 36(5), 1993,23-27$.

[210] L. Sproull \& S. Kiesler, "Computers, Networks, and Work", Scientific American, 264(3), setembro 1991, 84-91.

[211] L. Sproull \& S. Kiesler, Connections: New Ways of Working in the Networked Organization, MITPress, Cambridge,MA. 1991.

[212] N. Streitz, "Mental Models and Metaphors: Implications for the Design of Adaptive User-System Interfaces", in: H.Mandl \& A. Lesgold (eds.), Learning Issues for Intelligent Tutoring Systems, SpringerVerlag, Berlin, 1988, 164-186.

[213] L. Suchman, "Designing with the User", ACM Transactions on Office Information Systems, 6(2), 1988, 173-183.

[214] L. Suchman, "Response to Vera and Simon's Situated Action: A Symbolic Interpretation", Cognitive Science, 17(1), 1993, 71-75.

[215] L. Suchman, Plans and Situated Actions: The Problem of Human-Machine Communication, Cambridge University Press, Cambridge, MA, 1990. 
[216] J. W. Sullivan \& S. W. Tyler (eds.), Intelligent User Interfaces, ACM Press/ Addison-Wesley, NY/Reading, MA, 1991.

[217] V. J. Symons, "Impacts of Information Systems: Four Perspectives", Information and Software Technology, 33(3), abril 1991, 181-190.

\section{T}

[218] J. Tackara (ed.), Design After Modernism, Thames \& Hudson, London, 1988.

[219] J. E. Tiles, "Information Technology from Homer to DENDRAL", International Studies in the Philosophy of Science, 4(2), 1990, 205-220.

[220] H. Timbleby, User Interface Design, ACM Press/Addison-Wesley, Wokingham, UK, 1990.

[221] A. Toffler, Powershift: As Mudanças do Poder, Record, RJ, 1990.

$\mathbf{W} / \mathbf{Z}$

[222] Y. Waern, S. Hăgglund, J. Longren, I. Rankin, T. Sokolnicki \& A. Steineman, "Communication Knowledge and Knowledge Communication", International Journal of Man-Machine Studies, 37(6), 1992, 215-239.

[223] J. V. Wertsch (ed.), Culture, Communication and Cognition: Vygotskian Perspectives, Cambridge University Press, Cambridge, 1988.

[224] J. V. Wertsch, Vygotsky and the Social Fomation of Mind, Harvard University Press, Cambridge, 1986.

[225] T. Winograd \& F. Flores, Understanding Computers and Cognition. Ablex, Norwood, 1985.

[226] T. Winograd, "Guest Editors Introduction: Special Issue on the Language/Action Perspective", ACM Transactions on Office Information Systems, 6(2), 1988, 83-86.

[227] T. Winograd, "What Can We Teach About Human-Computer Interaction", in: J. C. Chew \& J. Whiteside (eds.), Empowering People, Proceedings of the ACM SIGCHI Conference, ACM Press, 1990 , 443-449.

[228] K. Wright, "The Road to the Global Village", Scientific American, 263(9), março 1990, 82-94.

[229] S. Zuboff, In the Age of the Sman Machine: The Future of Work and Power, Basic Books, NY, 1988. 

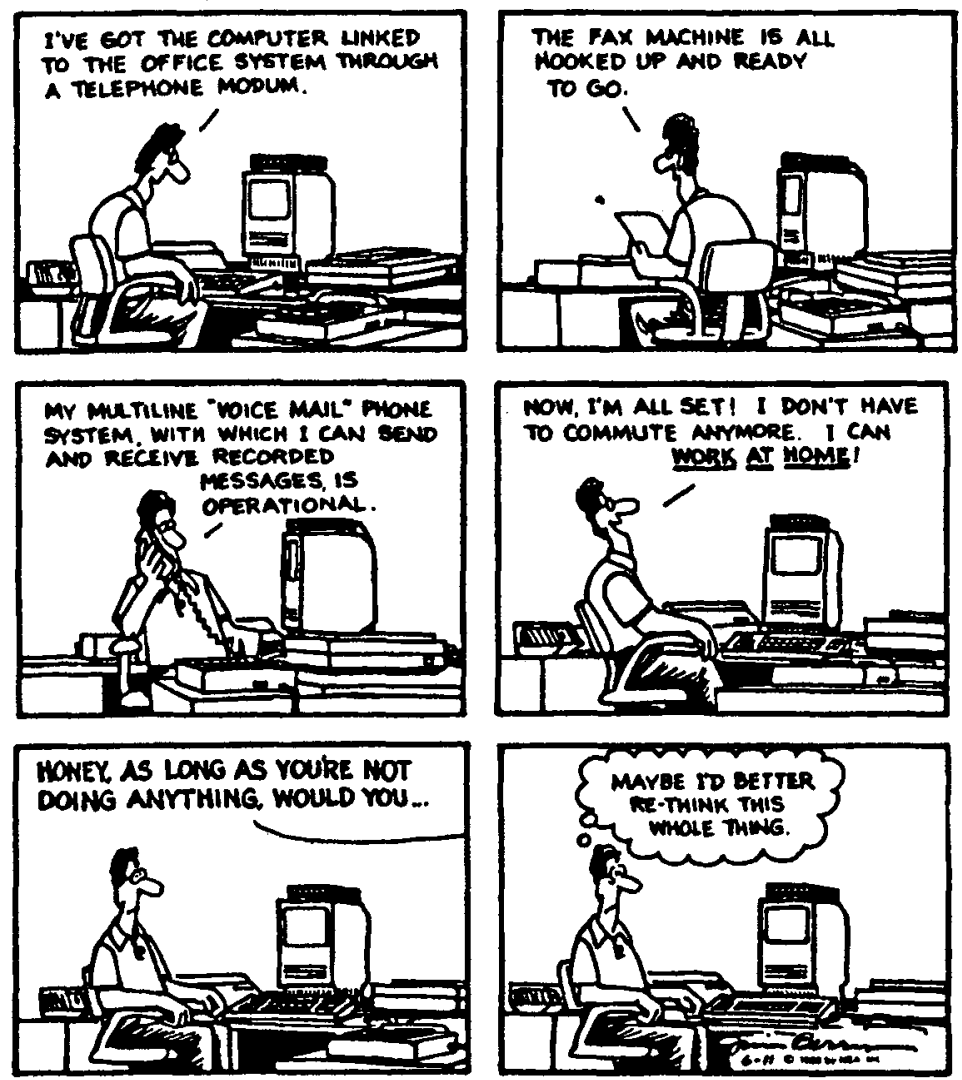